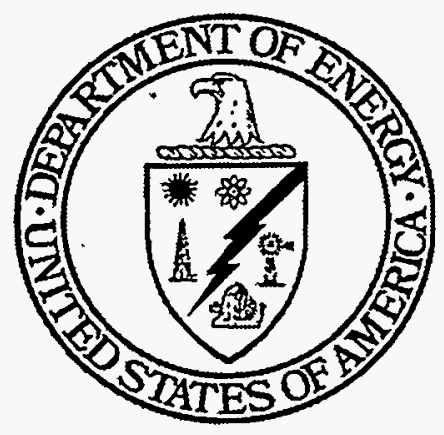

U.S. Depariment of Energy Office of Environmental Restoration and Waste Management Office of Technology Development

\section{Contaminated Concrete:} Occurrence and Emerging Technologies for DOE Decontamination

August 1995 
This report has been reproduced directly from the best available copy.

Available to DOE and DOE Contractors from the Office of -Scientific and Technical Information, P. O. Box 62, Oak Ridge, TN 37831; prices available from (615) 576-8401.

Available to the public from the U.S. Department of Commerce, Technology Administration, National Technical Information Service, Springfield, VA 22161, (703) $487-4650$.

\section{DISCLAIMER}

This report was prepared as an account of work sponsored by an agency of the United States Government. Neither the United States Government nor any agency thereof, nor any of their employees, makes any warranty, express or implied, or assumes any legal liability or responsibility for the accuracy, completeness, or usefulness of any information, apparatus, product, or process disclosed, or represents that its use would not infringe privately owned rights. Reference herein to any specific commercial product, process, or service by trade name, trademark, manufacturer, or otherwise does not necessarily constitute or imply its endorsement, recommendation, or favoring by the United States Government or any agency thereof. The views and opinions of authors expressed herein do not necessarily state or reflect those of the United States Government or any agency thereof. 


\section{DISCLAIMER}

Portions of this document may be illegible in electronic image products. Images are produced from the best available original document. 


\section{CONTAMINATED CONCRETE: \\ OCCURANCE AND EMERGING TECHNOLOGIES \\ FOR DOE DECONTAMINATION}

K. S. Dickerson ${ }^{1}$

M. J. Wilson-Nichols ${ }^{1}$

M. I. Morris ${ }^{2}$

August 1995

Prepared for the

U. S. Department of Energy

Office of Technology Development

Office of Environmental Management

Prepared by

Oak Ridge National Laboratory

P. O. Box 2008

Oak Ridge, Tennessee 37830

Managed By

Lockheed Martin Energy Systems, Inc.

for the

U. S. Department of Enegy

Under Contract DE-AC05-84OR21400

$1 \quad$ Health Sciences Research Division, ORNL/Grand Junction office

2 Chemical Technology Division, ORNL 



\section{CONTENTS}

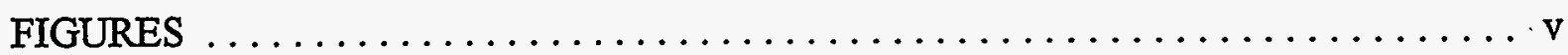

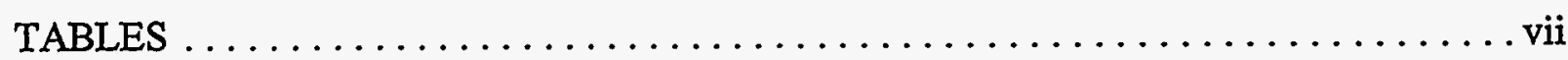

ACRONYMS, ABBREVIATIONS, AND INITIALISMS $\ldots \ldots \ldots \ldots \ldots \ldots \ldots$ ix

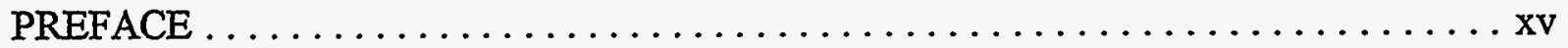

ACKNOWLEDGMENTS $\ldots \ldots \ldots \ldots \ldots \ldots \ldots \ldots \ldots \ldots \ldots \ldots \ldots \ldots \ldots \ldots \ldots \ldots$ xvii

EXECUTIVE SUMMARY $\ldots \ldots \ldots \ldots \ldots \ldots \ldots \ldots \ldots \ldots \ldots \ldots \ldots \ldots \ldots \ldots \ldots \ldots \ldots$

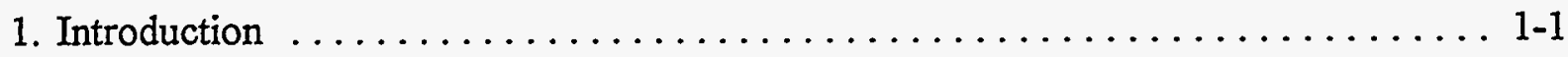

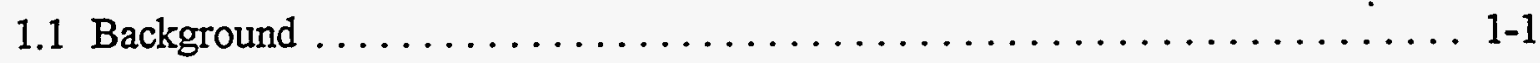

1.2 Objectives and Scope $\ldots \ldots \ldots \ldots \ldots \ldots \ldots \ldots \ldots \ldots \ldots \ldots \ldots \ldots \ldots \ldots \ldots \ldots \ldots \ldots \ldots, 2$

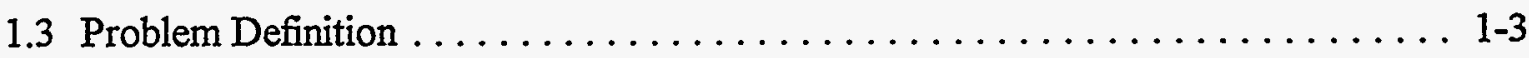

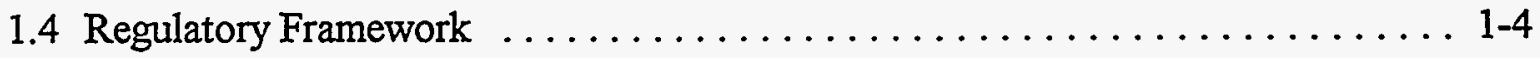

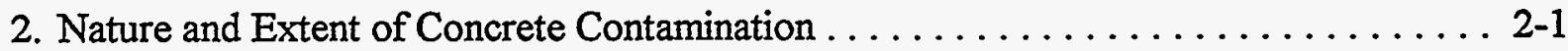

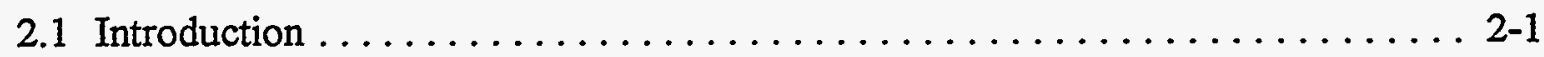

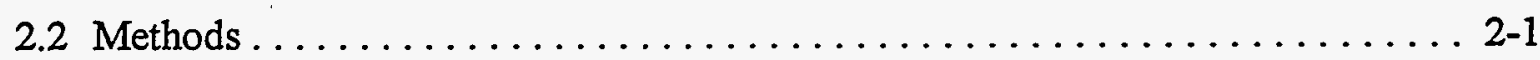

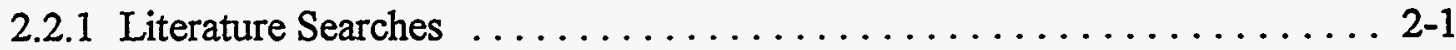

2.2.2 Surplus Facility Inventory and Assessment (SFIA) Data Base . . . . . . 2-2

2.2.3 Baseline Environmental Remediation Report (BEMR) Data Base ...... 2-3

2.2.4 CROSSWALK Data Base ......................... 2-3

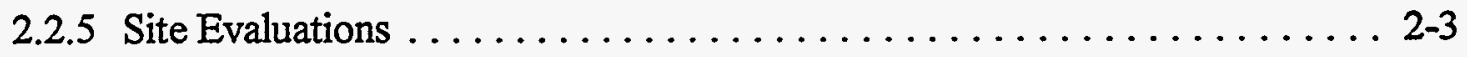

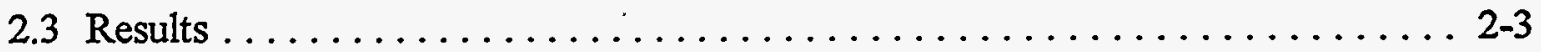

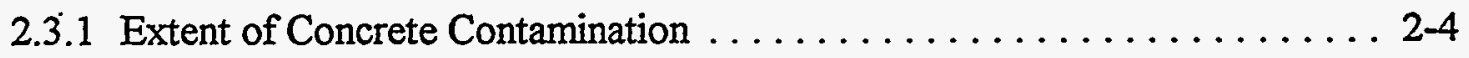

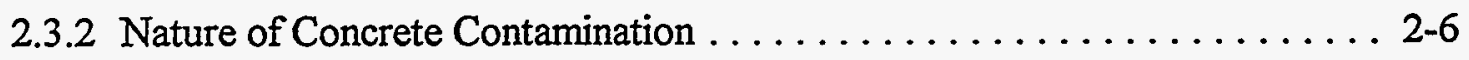

2.3.3 Previous DOE Experience with Concrete Decontamination ......... 2-8

2.3.4 Concrete Contamination in Facilities under NRC Control .......... 2-9

2.3.5 General Concrete Decontamination Technology Needs at DOE Sites ... 2-10 


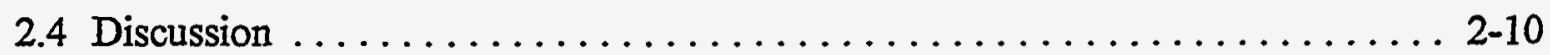

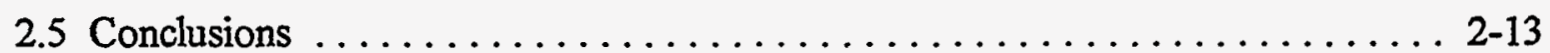

3. Candidate Technologies for Concrete Decontamination .............. 3-1

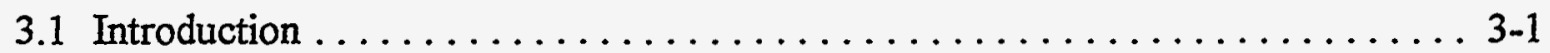

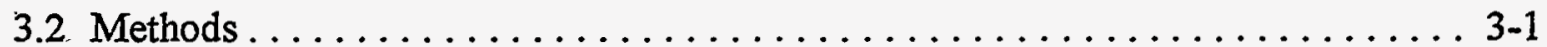

3.3 Results and Discussion $\ldots \ldots \ldots \ldots \ldots \ldots \ldots \ldots \ldots \ldots \ldots \ldots \ldots \ldots \ldots \ldots \ldots \ldots .2$

3.3.1 Concrete Decontamination Research in Academia ............. 3-2

3.3.2 Emerging Technologies $\ldots \ldots \ldots \ldots \ldots \ldots \ldots \ldots \ldots \ldots \ldots \ldots \ldots \ldots, 3$

3.3.3 Commercial Technologies $\ldots \ldots \ldots \ldots \ldots \ldots \ldots \ldots \ldots \ldots \ldots . \ldots \ldots$

4. Screening and Matching Problems with Emerging Technologies $\ldots \ldots \ldots \ldots .4-1$

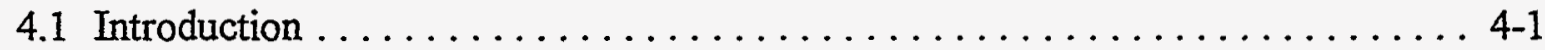

4.2 Methods . . . . . . . . . . . . . . . . . . . . .

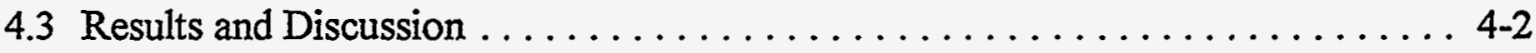

4.4 Conclusions $\ldots \ldots \ldots \ldots \ldots \ldots \ldots \ldots \ldots \ldots \ldots \ldots \ldots \ldots \ldots \ldots, 4$

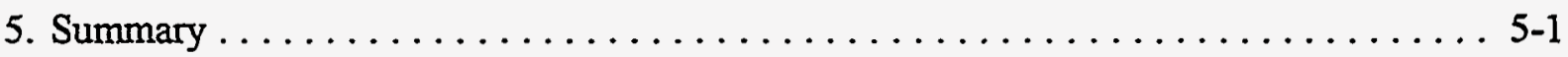

6. References $\ldots \ldots \ldots \ldots \ldots \ldots \ldots \ldots \ldots \ldots \ldots \ldots \ldots \ldots \ldots .6 .1$

7. Selected Bibliography $\ldots \ldots \ldots \ldots \ldots \ldots \ldots \ldots \ldots \ldots \ldots \ldots \ldots \ldots \ldots \ldots \ldots \ldots \ldots, 1$

8. Index of Candidate Technologies for Concrete Decontamination $\ldots \ldots \ldots \ldots$. 8-1

APPENDIX A Site Evaluations

APPENDIX B Data Base Information

APPENDIX C Technology Description Fact Sheets

APPENDIX D Regulatory Issues 


\section{FIGURES}

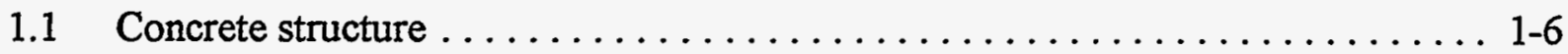

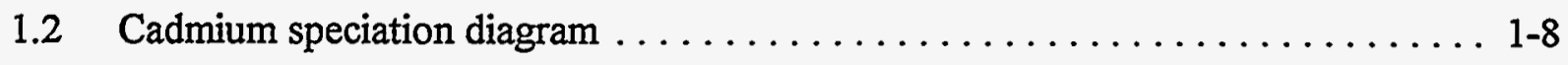

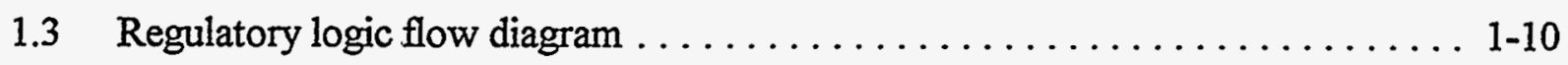

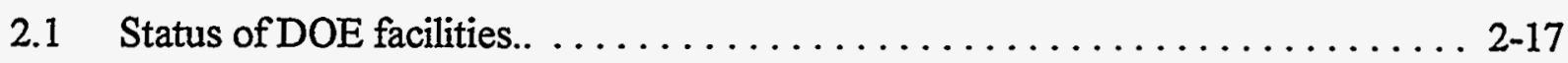

2.2 Occurrence of contaminants representative of the DOE complex. $\ldots \ldots \ldots 2-23$

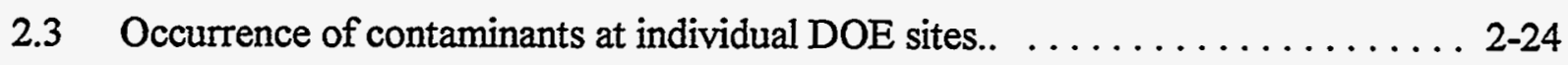

4.1 Managing technologies for deployment $\ldots \ldots \ldots \ldots \ldots \ldots \ldots \ldots \ldots \ldots$ 


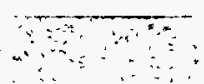




\section{TABLES}

1.1 Dominant species in cement pore solutions $\ldots \ldots \ldots \ldots \ldots \ldots \ldots \ldots \ldots \ldots$

1.2 Calculated surface radiation dose rates as functions of the number of surface

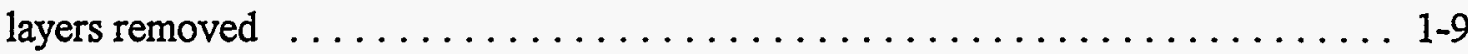

1.3 Generic guidelines for residual radionuclides in soil $\ldots \ldots \ldots \ldots \ldots \ldots \ldots 1-11$

2.1 Listing of sites for which concrete contamination data were found $\ldots \ldots \ldots \ldots$ 2-14

2.2 Ranking of concrete problems at $\mathrm{DOE}$ facilities $\ldots \ldots \ldots \ldots \ldots \ldots \ldots \ldots \ldots \ldots \ldots$

2.3 Concrete contamination in DOE facilities . . . . . . . . . . . . . . . 2-19

2.4 Estimated floor contamination in DOE facilities as reported in the BEMR data base $\ldots \ldots \ldots \ldots \ldots \ldots \ldots \ldots \ldots \ldots \ldots \ldots \ldots \ldots \ldots \ldots . .2-20$

2.5 Summary of nature and extent of concrete contamination based on site queries . 2-21

2.6 Summary of technology assessment based on site queries $\ldots \ldots \ldots \ldots \ldots .2-29$

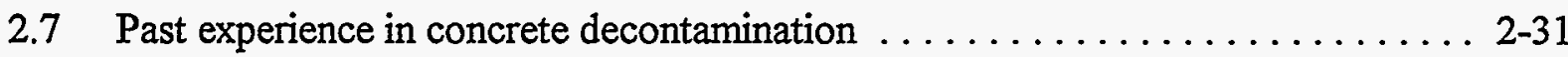

2.8 Total and contaminated surface areas for structures at NRC reference sites . . . . 2-38

2.9 DOE concrete decontamination technology needs $\ldots \ldots \ldots \ldots \ldots \ldots \ldots$ 2-39

3.1 Universities queried regarding technology $R \& D$ for $D \& D \ldots \ldots \ldots \ldots \ldots .20$

3.2 Commercially available concrete $\mathrm{D} \& \mathrm{D}$ technologies based on vendor responses . 3-21

3.3 Emerging candidate technologies for concrete decontamination $\ldots \ldots \ldots \ldots$ 3-23

3.4 Commercially available candidate technologies for concrete decontamination . . . 3-26

3.5 Summary of candidate technologies for concrete decontamination . . . . . . . 3-28

3.6 Estimated costs for emerging concrete decontamination technologies . . . . . 3-32

4.1 Matching of concrete decontamination problems with emerging technologies . . . 4-7

4.2 Evaluation of potential demonstration usefulness $\ldots \ldots \ldots \ldots \ldots \ldots \ldots, 8$

4.3 Results from technology demonstration evaluation ............... 4-14 
A

ALARA

AMES

ANL

ANLE

ANLW

ANSI

ARAs

ARC

ATTIC

BAPL

BCL

BEMR

BET

BGRR

BNL

BRC

CCR

CERCLA

CFA

CISS

$\mathrm{cm}$

CPC

CRADA

CRS ampere

as low as reasonably achievable

Ames Laboratory

Argonne National Laboratory

Argonne National Laboratory East

Argonne National Laboratory West

American National Standards Institute

Auxiliary Reactor Areas

Applied Radiological Controls

Alternative Treatment Technology Information Center

Bettis Atomic Power Laboratory

Battelle Columbus Laboratories Decommissions Project

Baseline Environmental Remediation Report

Brunauer-Emmett-Teller

Brookhaven geophite research reactor

Brookhaven National Laboratory

below regulatory concern

Chemical Crane Room

Comprehensive Environmental Response,

Compensation, and Liability Act (Superfund)

Central Facilities Area

Colonie Interim Storage Site

centimeter

Chemical Process Cell

cooperative research and development agreement

chloride removal system 
D\&D

DC

DOD

DOE

DOT

dpm

DT\&E

DWPF

EDR

EDTA

$\mathrm{EH}$

EK

EM

EPA

ER

ETEC

ETR

FEMP

FFCA

ft

FUSRAP

FY

$\mathrm{g}$

GA

gal

GEIS

$\mathrm{GHz}$

GJPO deactivation, decontamination, and decommissioning direct current

U. S. Department of Defense

U. S. Department of Energy

U.S. Department of Transportation

disintegrations per minute

demonstration, testing, and evaluation

defense waste processing facility

Equipment Decontamination Room

ethylenediaminetetracetic acid

Environmental Health

electrokinetic

Environmental Restoration and Waste Management

U. S. Environmental Protection Agency

environmental restoration

Energy Technology Engineering Center

Engineering Test Reactor

Fernald Environmental Management Project

Federal Facility Compliance Agreements

feet

Formerly Utilized Sites Remedial Action Program

fiscal year

grams

General Atomics

gallons

generic environmental impact statement

gigahertz

Grand Junction Projects Office 
h

HANF

HEPA

HLR

HLW

IAG

ICPP

ICRP

IDP

in.

INEL

ITRI

KAPL

$\mathrm{KCP}$

$\mathrm{keV}$

$\mathrm{kV}$

$\mathrm{kW}$

L

LANL

Ib

LBL

LDR

LEHR

LLMW

LLNL

LLR

LLW

m hour

Hanford Site

high-efficiency particulate air

High-level radiation

high-level (radioactive) waste

interagency agreement

Idaho Chemical Processing Plant

International Commission on Radiological Protection

Integrated Demonstration Program

inch

Idaho National Engineering Laboratory

Inhalation Toxicology Research Institute

Knolls Atomic Power Laboratory

Kansas City Plant

kilolectron volt

kilovolt

kilowatt

liter

Los Alamos National Laboratory

pound

Lawrence Berkeley Laboratory

land disposal regulation

Laboratory for Energy-Related Health Research

low-level mixed waste

Lawrence Livermore National Laboratory

low level radiation

low-level (radioactive) waste

meter 
M

$\mathrm{mA}$

METC

$\min$

$\mathrm{mL}$

$\mu \mathrm{m}$

MND

$\mathrm{mR}$

$\mu \mathrm{R} / \mathrm{h}$

mrem

MRI

MTR

$\mathrm{nCi}$

NCRP

NEPA

NMR

NRC

NRF

NTS

ORISE

ORNL

ORR

OU

$\mathrm{pCi} / \mathrm{g}$

PANT

PBF

PCB molar

milliampere

Morgantown Energy Technology Center

minute

milliliter

micron

Mound Plant

milliroentgen

micro roentgen per hour

millirem

magnetic resonance imaging

Materials Test Reactor

nanocurie

National Council on Radiation Protection and

Measurement

National Environmental Policy Act

nuclear magnetic resonance

U. S. Nuclear Regulatory Commission

Naval Reactors Facility

Nevada Test Site

Oak Ridge Institute for Science and Education

Oak Ridge National Laboratory

Oak Ridge Reservation

operable unit

picocureies per grams

Pantex Plant

Power Burst Facility

polychlorinated biphenyl 
PEIS

PGDP

PINP

PNL

PORTS

ppm

PPPL

psi

$\mathrm{R} \& \mathrm{D}$

RAPIC

RCRA

redox

RF

RFETS

RI/FS

RMA

RMDF

RMIDP

RMIT

ROD

RWMC

SFIA

SLAC

SNF

SNLL

SRS

SSAB

TAN
Programmatic Environmental Impact Statement

Paducah Gaseous Diffusion Plant

Pinellas Plant

Pacific Northwest Laboratory

Portsmouth Gaseous Diffusion Plant

parts per million

Princeton Plasma Plysics Laboratory

pounds per square inch

research and development

Remedial Action Program Information Center

Resource Conservation and Recovery Act

reduction-oxidation

radio frequency

Rocky Flats Environmental Technology Site

remedial investigation/feasibility study

Rocky Mountain Arsenal

Radioactive Materials Disposal Facility

RMI Decommissioning Project

RMI Titanium, Inc.

Record of Decision

Radioactive Waste Management Complex

Surplus Facility Inventory and Assessment

Stanford Linear Accelerator Center

spent nuclear fuel

Sandia National Laboratories

Savannah River Site

site-specific advisory board

Test Area North 
TEDE

TRA

TRU

TSCA

TSF

TTP

UHPN

UV

$\mathrm{V}$

WAC

WINCO

WIPP

WL

WSS

WVDP total effective dose equivalent

Test Reactor Area

transuranic (element)

Toxic Substances Control Act

test support facilities

technical task plan

ultrahigh-pressure water

ultraviolet light

volt

waste acceptance criteria

Westinghouse Idaho Nuclear Company

Waste Isolation Pilot Plant

working level

Weldon Spring Site

West Valley Demonstration Project 


\section{PREFACE}

The information presented in this report was compiled as part of a larger project focused on demonstrating emerging technologies for concrete decontamination within the U.S. Department of Energy complex. Descriptions of the nature and extent of contaminated concrete and potentially applicable emerging technologies are presented in this document as an aid to those who develop technologies as well as those responsible for technology selection and implementation. This project focused on assimilation and review of existing compilations of data both to minimize duplication of previous efforts and to gather the currently available information into one location to help identify areas that require more data and areas of potential concern in the future.

An index of the candidate technologies described within this report appears following the bibliography. 


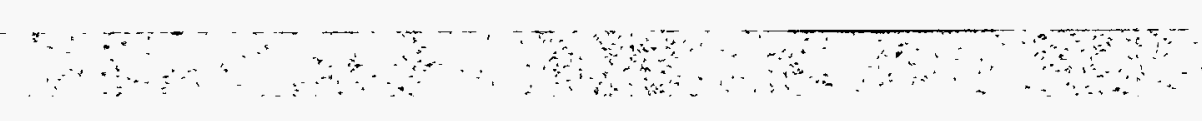




\section{ACKNOWLEDGMENTS}

This document was prepared through the combined efforts of scientific and engineering staff at Oak Ridge National Laboratory, with sponsorship provided by the Facility Deactivation, Decommissioning and Material Disposition Focus Area of the DOE Office of Technology Development. Mr. Jerry Hyde, DOE/Headquarters Program Manager, Mr. Jerry Harness, DOE/Oak Ridge Operations Office Program Manager, and Mr. Keith Kibbe, Focus Area Technical Coordinator, are acknowledged for their guidance and oversight. Both internal and external peer reviewers are also acknowledged for their contributions.

\section{Contributors:}
M. R. Ally
D. K. Barslund
C. E. Benson
C. H. Brown
K. S. Dickerson
P. V. Egidi
D. S. Foster
R. G. Grubb
K. A. Hebbard
N. E. Korte
B. J. Krall
M. Medina
E. Milliken
M. I. Morris
C. A. Muhr
P. D. Roundtree
R. Stegen
M. J. Wilson-Nichols

Chemical Technology Division, ORNL Health Sciences Research Division, ORNL Chemical Technology Division, ORNL Chemical Technology Division, ORNL Health Sciences Research Division, ORNL Health Sciences Research Division, ORNL Health Sciences Research Division, ORNL Parsons Engineering Sciences, Inc. Health Sciences Research Division, ORNL Environmental Sciences Division, ORNL Health Sciences Research Division, ORNL Advanced Integrated Management Services Parsons Environmental Sciences, Inc. Chemical Technology Division, ORNL Health Sciences Research Division, ORNL Health Sciences Research Division, ORNL Parsons Environmental Sciences, Inc. Health Sciences Research Division, ORNL

\section{Reviewers:}
B. Austin
C. Baldwin
R. D. Bundy
F. M. Heckendorn
D. W. MacAuthur
D. Martineit

Westinghouse Savannah River Company EG\&G/Rocky Flats

Battelle Memorial Institute

Westinghouse Savannah River Company

Los Alamos National Laboratory

Fernald Environmental Restoration Management Corp. 



\section{EXECUTIVE SUMMARY}

The goals of the Facility Deactivation, Decommissioning, and Material Disposition Focus Area, sponsored by the U. S. Department of Energy (DOE) Office of Technology Development, are to select, demonstrate, test, and evaluate an integrated set of technologies tailored to provide a complete solution to specific problems posed by deactivation, decontamination, and decommissioning, (D\&D). In response to these goals, technical task plan (TTP) OR152002, entitled Accelerated Testing of Concrete Decontamination Methods, was submitted by Oak Ridge National Laboratory. This report describes the results from the initial project tasks, which focused on the nature and extent of contaminated concrete, emerging candidate technologies, and matching of emerging technologies to concrete problems.

Existing information was used to describe the nature and extent of contamination (technology logic diagrams, data bases, and the open literature). To supplement this information, personnel at various DOE sites were interviewed, providing a broad perspective of concrete contamination. Because characterization is in the initial stage at many sites, complete information is not available. Assimilation of available information into one location is helpful in identifying potential areas of concern in the future. For example, incomplete characterization information from the gaseous diffusion plants indicates that estimates of the extent of contamination are low and can be expected to increase significantly as data become available.

The most frequently occurring radiological contaminants within the DOE complex are ${ }^{137} \mathrm{Cs}$, ${ }^{238} \mathrm{U}$ (and it daughters), and ${ }^{60} \mathrm{Co}$, followed closely by ${ }^{90} \mathrm{Sr}$ and tritium, which account for $\sim 30 \%$ of the total occurrence. Twenty-four percent of the contaminants were listed as unknown, indicating a lack of characterization information, and $24 \%$ were listed as other contaminants (over 100 isotopes) with less than $1 \%$ occurrence per isotope. With additional characterization data from the sites, the order of contaminant frequency is expected to change, but it is likely that ${ }^{137} \mathrm{Cs},{ }^{238} \mathrm{U},{ }^{60} \mathrm{Co},{ }^{90} \mathrm{Sr}$, and tritium will remain the most commonly occurring isotopes.

The total area of contaminated concrete within the DOE complex is estimated to be in the range of $7.9 \times 10^{8} \mathrm{ft}^{2}$ or approximately 18,000 acres. The volume of contaminated concrete (areal extent multiplied by the estimated depth of contamination) is estimated at $6.7 \times 10^{6} \mathrm{ft}^{3}$. These figures are based on different data sets both containing incomplete information due to the various stages of site characterization. Thus, the estimates are low and are expected to increase (possibly double) as additional characterization information becomes available.

Finally, concrete decontamination needs were identified as: (1) reduction of secondary waste, (2) cost- and schedule-effective technologies, and (3) innovative technologies for floor and wall decontamination. Several sites responded that the decontamination needs at the site were unknown. This was attributed to the fact that D\&D planning and implementation at many sites is still in preliminary stages. 
In addition to definition of the nature and extent of contamination (i.e., problem definition), information was assimilated on emerging candidate technologies for concrete decontamination. Several technologies were identified that meet one or more of the needs described above. These include chemical, mechanical, surface, and thermal technologies. The emerging processes identified include: biological surface cleaning, chemical gels, decontamination and recycle of concrete, electro-hydraulic scabbling, $\mathrm{EK}$ processes, centrifugal cryogenic $\mathrm{CO}_{2}$ blasting, concrete milling, remotely operated dry ice pellet decontamination, supercritical $\mathrm{CO}_{2}$ blasting, compressed air cryogenic $\mathrm{CO}_{2}$ blasting, dry heat (roasting), solvent washing, chromographic strippable coatings, flashlamp, laser etching and ablation, laser heating, microwave scabbling, and plasma torch.

Initially, no attempt was made to screen the technologies based on the stage of development of the process (i.e., likelihood of demonstrating process by FY96) or other factors. Information was gathered on the limiting conditions, processing rates, cost, and removal efficiency. The results of these activities, as presented in this report, were used to match technologies to problems as part of a larger project that provided the basis for recommendations to DOE for demonstrations to be conducted as part of the Accelerated Testing of Concrete Decontamination Methods project. Emerging technologies considered to provide the most potential benefit to decontamination of concrete within the DOE complex were biological decontamination, electro-hydraulic scabbling, electrokinetics, and microwave scabbling. 


\section{Introduction}

\subsection{Background}

Because of the end of the Cold War and the decision to reduce the size of the nuclear weapons production complex, the U. S. Department of Energy (DOE) has begun deactivation, decontamination, and decommissioning (D\&D) of a large number of aging, surplus facilities (U.S. DOE 1994a). Located throughout the U.S, these facilities require a monumental cleanup effort that must also minimize impact and risk to workers and the environment. Technologies that will address these problems quickly and cost-effectively are needed.

In response to these needs, the DOE Office of Technology Development within the Office of Environmental Restoration and Waste Management (EM) created the Facility Deactivation, Decommissioning, and Material Disposition Focus Area. The strategic plan of this focus area identified several technical areas for both further investigation and for implementation of technology demonstrations. These technical areas include: concrete, fuel reprocessing, fuel storage basins, gaseous diffusion plant equipment, hot cells, lithium-processing facilities, metals recycling, plutonium-processing facilities, reactors, and uranium-processing facilities (U.S. DOE 1994a). The goals of the demonstrations within each technical area are to: (1) optimize the use of DOE resources by planning and by avoiding duplication; (2) demonstrate cradle-to-grave methods and solutions; (3) effect desired facility end use; (4) maximize reuse and recycling of materials and equipment; (5) minimize waste types and volumes; and (6) ensure adequate protection to workers, the public, and the environment. It is intended that these demonstrations will provide a solid basis for selecting improved technical approaches to D\&D and related activities.

In many cases, closure or transition of a facility cannot take place until contaminated concrete is either disposed of or decontaminated. In the past, small-scale technologies for decontamination were adequate and may still be appropriate for some tasks; however, exclusive reliance on these technologies could result in deficiencies such as high costs and large waste volumes in the expanding D\&D program (U.S. DOE 1994a). In addition, existing technologies may also expose workers to radiation and hazardous substances unnecessarily. Thus, the emphasis of the focus area demonstrations is on emerging or innovative technologies that address deficiencies in available technologies.

A technical task plan (TTP) entitled Accelerated Testing of Concrete Decontamination Methods was submitted by Oak Ridge National Laboratory (ORNL) in response to the needs outlined for D\&D of concrete-contaminated facilities. The project described in the TTP will identify and demonstrate innovative technologies that reduce the costs associated with existing technologies relying on physical removal and disposal of contaminated portions of buildings and structures. This report presents information compiled during the project: identification of the 
nature and extent of contaminated concrete within the DOE complex and candidate technologies applicable to the widely occurring problems. It is intended that this report will provide an overview of concrete decontamination throughout the DOE complex and will assist site personnel in choosing concrete decontamination technologies.

Section 1 of this report, the Introduction, includes the objectives of the project and a description of concrete and its properties as they apply to contaminants. A brief discussion of the regulations covering the decontamination of concrete is also included.

Section 2 outlines the extent of contaminated concrete throughout the DOE complex and the specific contaminants found. Included are discussions of findings for both DOE and NRC facilities. Information regarding the technologies needed to effect decontamination is also presented.

Section 3 describes the technologies, both emerging and existing, considered to be candidates for decontamination of concrete. The process used to determine which technologies are applicable is also outlined. Several tables summarizing these technologies are included.

The technologies described in Sect. 3 were evaluated and screened in an effort to match specific technologies to decontamination problems. Section 4 discusses this screening and matching process and presents the recommendations for demonstrations.

Section 5 is a summary of the report.

\subsection{Objectives and Scope}

To describe the scope of contamination, two approaches were taken: existing literature and data bases were reviewed, and DOE personnel were interviewed both personally and by means of written survey. Candidate technologies were investigated by means of literature and data base searches and by personal contact with private industry vendors and developers of new technology. The project has relied on assimilating existing information from past efforts in order to minimize duplication of efforts (e.g., logic diagrams, data bases). Although the focus is on emerging technologies, commercially available technologies are also presented. The results of these activities, as presented in this report, were the basis for recommendations to DOE for demonstrations to be conducted as part of the Accelerated Testing of Concrete Decontamination Methods project. 


\subsection{Problem Definition}

As a common material used widely throughout $\mathrm{DOE}$ facilities, concrete has been contaminated with a variety of hazardous chemicals, heavy metals, and radionuclides. The extent of contaminated concrete varies widely, from loose and fixed surface contamination to contamination within concrete joints and cracks. In some cases, contamination has penetrated more deeply into the concrete, such as technetium, tritium, and contaminants under a hydrostatic head (e.g., from reactor pools). To select a technology for decontamination, an understanding of concrete characteristics and contaminant transport within concrete is important.

Construction-grade concrete is composed of a cement binder and aggregate. The aggregate is generally in the form of small rocks of mixed composition. For structural strength, concrete is usually poured around or over a metallic grid system, commonly called rebar or reinforcing bar. The grid system is composed of either steel rods wired together at their intersections or wire mesh similar to that produced for use as fencing material. Although generally perceived as a static, non-porous, and inert material, concrete is very porous and provides a complex, dynamic medium for chemical reactions. For example, hydration reactions, the chemical reactions that transform freshly poured concrete into a relatively solid mass, have been observed to continue in concrete for several years.

In dealing with contaminated concrete, one property of particular importance is specific surface area. The large surface area $\left(3220 \mathrm{~cm}^{2} / \mathrm{g}\right)$ combined with the porosity of the material (reportedly as high as $60 \%$ pores by volume) results in a complex and active system for interaction with contaminants (Bostick et al. 1993). The structure of concrete is composed of three different but integrated phases. The more familiar solid phase, in which calcium and silica form solid hydration products, is shown in Fig. 1.1 (Glasser 1991). The voids in this system are coated with both sorbed and free water containing dissolved salts present from the concrete materials as well as dissolved contaminants that may have been introduced. Typical ions present in the pore water are listed in Table 1.1 (Roy and Scheetz 1991). The complexity of the system increases as contaminants react with and are influenced by the pore water.

Another characteristic that greatly influences the behavior of contaminants in concrete is $\mathrm{pH}$. Typically $\mathrm{pH}$ is greater than 13 in the pore space (Roy and Scheetz 1991). The importance of $\mathrm{pH}$ is based on the fact that many metals, both radioactive and non-radioactive, are insoluble at this $\mathrm{pH}$ and, therefore, precipitate as solids within the pores of the structure (Cocke and Mollah 1991). Speciation diagrams, such as the one shown in Fig. 1.2 for cadmium, can be used to predict the state of the contaminant within the cement matrix. The advantage of material precipitation is that contaminants will not penetrate the concrete to any great depth and are expected to be present as precipitates within the first centimeters. 
Although the majority of contaminants will likely be present as precipitates, they may be incorporated into the cement matrix by means of several mechanisms. Contaminants may exist as inclusions or be subjected to chemisorption, chemical incorporation, or other binding mechanisms such as ion exchange reactions (Cocke and Mollah 1991).

An understanding of contaminant transport properties is also important for evaluating candidate technologies for concrete decontamination. Besides $\mathrm{pH}$, other parameters of the concrete medium that affect contaminant transport include porosity, permeability, saturation conditions, and time of exposure.

Estimates of depth of distribution of radionuclides in concrete were made by the U.S. Nuclear Regulatory Commission (NRC) to assess the amount of contaminated concrete that must be removed to attain acceptable surface gamma dose rates following decontamination (U.S. NRC 1994a). The diffusion of radionuclides into concrete surfaces that have been extensively exposed to water is faster than for dry concrete because diffusion takes place by a different mechanism through pores that are saturated with water than through dry pores. Radionuclides in samples of dry concrete were distributed much closer to the surface than in samples taken from wet areas. Diffusivities for a number of radionuclides were estimated to develop a method of calculating the radiation dose rates at the surface of contaminated concrete as successive layers were removed (U.S. NRC 1994a). Table 1.2 indicates that in this study of NRC sites, the contamination was confined to the top 1-in. surface layer (U.S. NRC 1994a).

In summary, contaminated concrete presents a complex system that is affected by a large number of parameters, including specific surface area, $\mathrm{pH}$, porosity, permeability, and saturation.

\subsection{Regulatory Framework}

Both federal and local regulations govern D\&D activities. For the purposes of this project, an understanding of the regulatory framework is important to identify performance goals for the evaluation of demonstrations. In other words, if a technology cannot reduce contamination to the necessary standards, then it should be removed from further consideration. Regulatory requirements may be changed, but such activities are outside the scope of this project. The following is a brief synopsis of applicable regulations. A more detailed discussion is presented in Appendix D.

As previously mentioned, the purpose of concrete decontamination is, in part, to facilitate closure or transition of buildings and facilities. The decontamination process is also intended to reduce or eliminate radiological worker exposure and to minimize disposal cost by limiting the volume of waste. Figure 1.3 presents a logic flow diagram for the overall management of radiologically contaminated concrete. 
The regulatory framework relating to free release and radiological waste disposal is complex and governed by a number of criteria. After concrete has been characterized, the options for final disposition can be identified. These options may include re-use of the building structure intact, recycling of the concrete for other purposes, or waste disposal. Depending on the level of contamination present, the concrete may need to be decontaminated in order to implement the selected disposition option.

The radiation criteria for protecting the public and the environment are contained in DOE Order 5400.5 , which establishes standards to ensure that potential exposures to radiation are maintained within expected limits and to control radioactive contamination through the management of property (U.S. DOE 1990). The generic guidelines for residual radionuclides in soil are presented in Table 1.3. If these guidelines are met and the contamination has been subjected to an as low as reasonably achievable (ALARA) evaluation, materials, including concrete, and equipment may be released for unrestricted use. If surfaces are not accessible, materials may be released on a case-by-case basis. It is important to note that DOE Order 5400.5 states that there is no current guidance for the release of materials contaminated at depth (e.g., activated material). A more detailed discussion of free-release criteria, including those being developed by DOE, NRC, and the U.S. Environmental Protection Agency (EPA), is presented in Appen$\operatorname{dix} \mathrm{D}$.

If concrete decontamination is not feasible, the primary final disposition option is to reduce the concrete to rubble for disposal as a radioactive waste. There is not a clear regulatory definition of a radioactive waste. The current conservative definition is any solid, liquid, or gaseous material that is to be discarded containing radionuclides distinguishable from background levels. Because de minimis limits have not been established for radionuclides, state and local regulatory approval on a case-by-case basis is required, with approval by DOE for disposal of slightly contaminated concrete at a non-radioactive landfill. If the concrete is to be managed as a radioactive waste, the disposal requirements will vary with respect to the level and type of radiological contamination. A more detailed discussion of radioactive waste disposal is presented in Appendix D. 


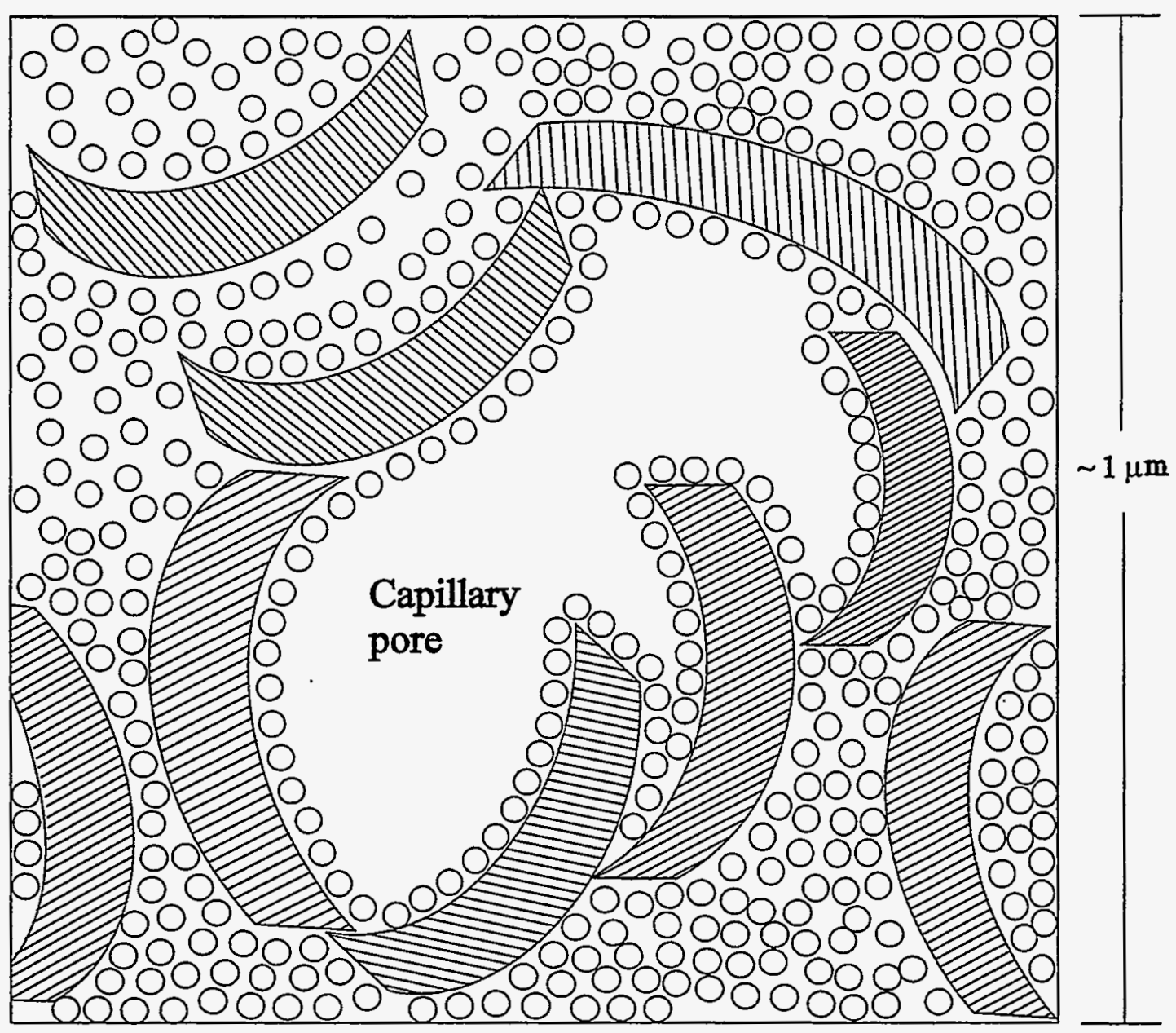

Calcium-silica hydration products

Water sorbed on particle surfaces

Fig. 1.1. Concrete structure. 
1-7

Table 1.1. Dominant species in cement pore solutions

\begin{tabular}{ccc}
\hline \hline Cations & Anions & Neutral \\
\hline $\mathrm{Ca}^{2+}$ & $\mathrm{Cl}^{-}$ & $\mathrm{H}_{4} \mathrm{SiO}_{4}$ \\
$\mathrm{Mg}^{2+}$ & $\mathrm{SO}_{4}{ }^{2-}$ & $\mathrm{H}_{2} \mathrm{CO}_{3}$ \\
$\mathrm{Na}^{+}$ & $\mathrm{HCO}_{3}^{-}$ & \\
$\mathrm{K}^{+}$ & $\mathrm{Fe}(\mathrm{OH})_{4}^{-}$ & \\
$\mathrm{H}^{+}$ & $\mathrm{Al}\left(\mathrm{OH}_{4}{ }^{-}\right.$ & \\
$\mathrm{MgOH}^{+}$ & $\mathrm{H}_{3} \mathrm{SiO}_{4}^{-}$ & \\
& $\mathrm{H}_{2} \mathrm{SiO}_{4}{ }^{2-}$ & \\
& $\mathrm{OH}^{-}$ & \\
& $\mathrm{CO}_{3}^{2-}$ \\
\end{tabular}

Source: Roy and Scheetz 1991 


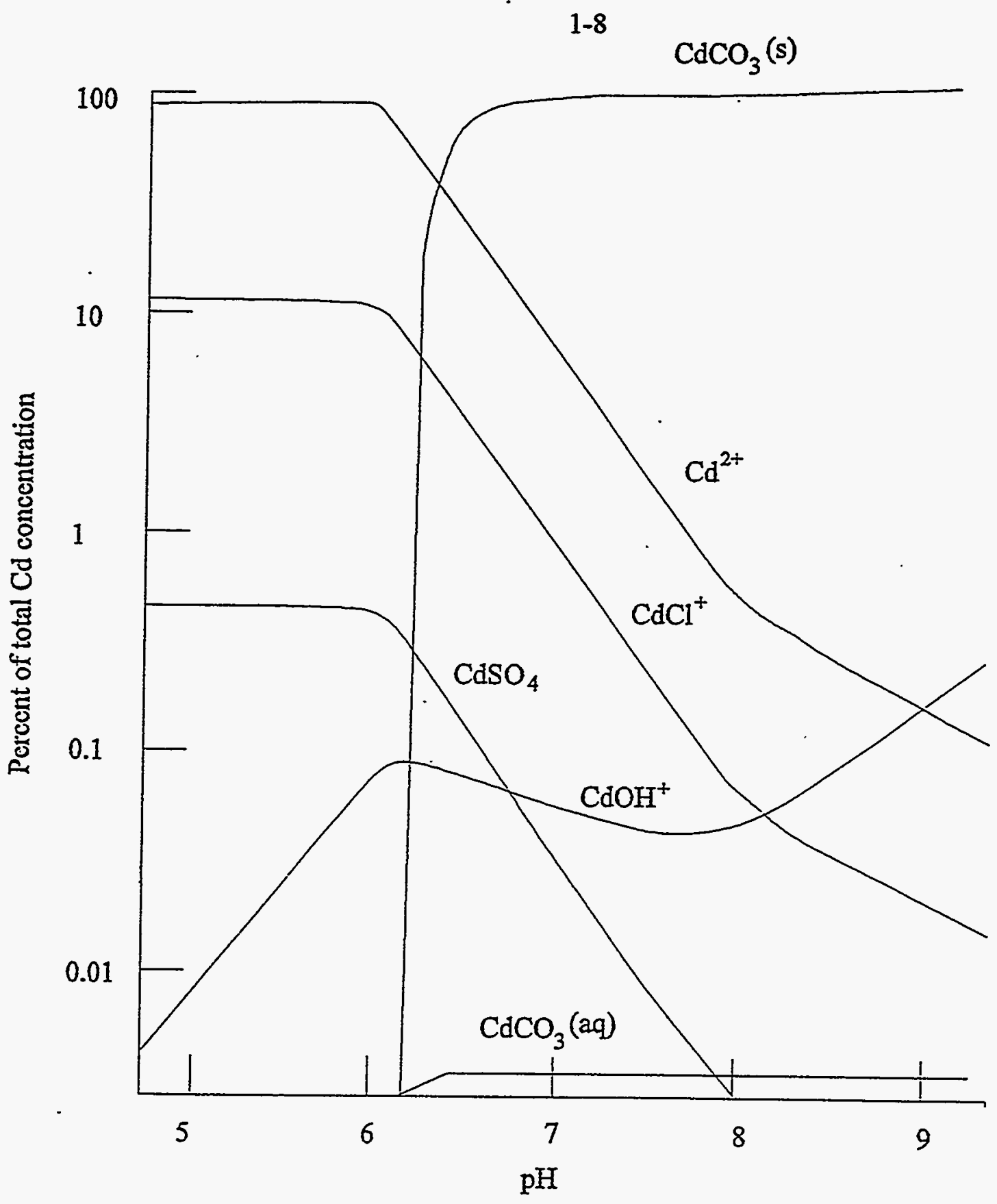

Fig. 1.2. Cadmium speciation diagram. Source: J. R. Conner, Chemical Fixation and Solidification of Hazardous Wastes, Van Nostrand Reinhold, New York, 1990. Copyright transferred to Chapman \& Hall, New York. Used by permission. 
Table 1.2. Calculated surface radiation dose rates as functions of the number of surface layers removed

\begin{tabular}{|c|c|c|c|c|c|c|}
\hline \multirow{3}{*}{$\begin{array}{c}\text { Depth to } \\
\text { new surface, } \\
\text { in. } / \mathrm{cm}\end{array}$} & \multicolumn{6}{|c|}{ Surface dose rate, mrem/year } \\
\hline & \multicolumn{3}{|c|}{${ }^{60} \mathrm{Co}$} & \multicolumn{3}{|c|}{${ }^{137} \mathrm{Cs}$} \\
\hline & Low & Moderate & High & Low & Moderate & High \\
\hline $0.125 / 0.3175$ & 4.09 & 428 & 31,700 & 0.519 & 56.2 & 4,060 \\
\hline $0.250 / 0.635$ & 0.0372 & 39.0 & 2,890 & 0.156 & 16.9 & 1,220 \\
\hline $0.375 / 0.9525$ & 0.00685 & 0.717 & 53.1 & 0.0212 & 2.3 & 166 \\
\hline $0.500 / 1.27$ & $2.55 \times 10^{-5}$ & 0.00267 & 0.198 & 0.00129 & 0.140 & 10.1 \\
\hline $0.625 / 1.5875$ & $1.92 \times 10^{-8}$ & $2.01 \times 10^{-6}$ & $1.49 \times 10^{-4}$ & $3.55 \times 10^{-5}$ & $3.85 \times 10^{-3}$ & 0.278 \\
\hline $0.750 / 1.905$ & $2.92 \times 10^{-12}$ & $3.05 \times 10^{-12}$ & $2.26 \times 10^{-8}$ & $4.38 \times 10^{-7}$ & $4.74 \times 10^{-5}$ & $3.43 \times 10^{-3}$ \\
\hline $0.875 / 2.223$ & $8.97 \times 10^{-17}$ & $9.40 \times 10^{-15}$ & $6.96 \times 10^{-13}$ & $2.43 \times 10^{-9}$ & $2.63 \times 10^{-7}$ & $1.90 \times 10^{-5}$ \\
\hline \multirow[t]{2}{*}{$1.000 / 2.54$} & $5.59 \times 10^{-22}$ & $5.85 \times 10^{-20}$ & $4.33 \times 10^{-18}$ & $6.06 \times 10^{-12}$ & $6.56 \times 10^{-10}$ & $4.75 \times 10^{-8}$ \\
\hline & \multicolumn{3}{|c|}{ Uranium } & \multicolumn{3}{|c|}{ Thorium } \\
\hline $0.125 / 0.3175$ & $7.55 \times 10^{-14}$ & $4.6 \times 10^{-12}$ & $4.2 \times 10^{-11}$ & $\overline{59.3}$ & 3,620 & 32,900 \\
\hline $0.250 / 0.635$ & -- & $\ldots$ & $\ldots$ & 0.000369 & 0.0225 & 0.205 \\
\hline
\end{tabular}

Source: U.S. NRC 1994a 


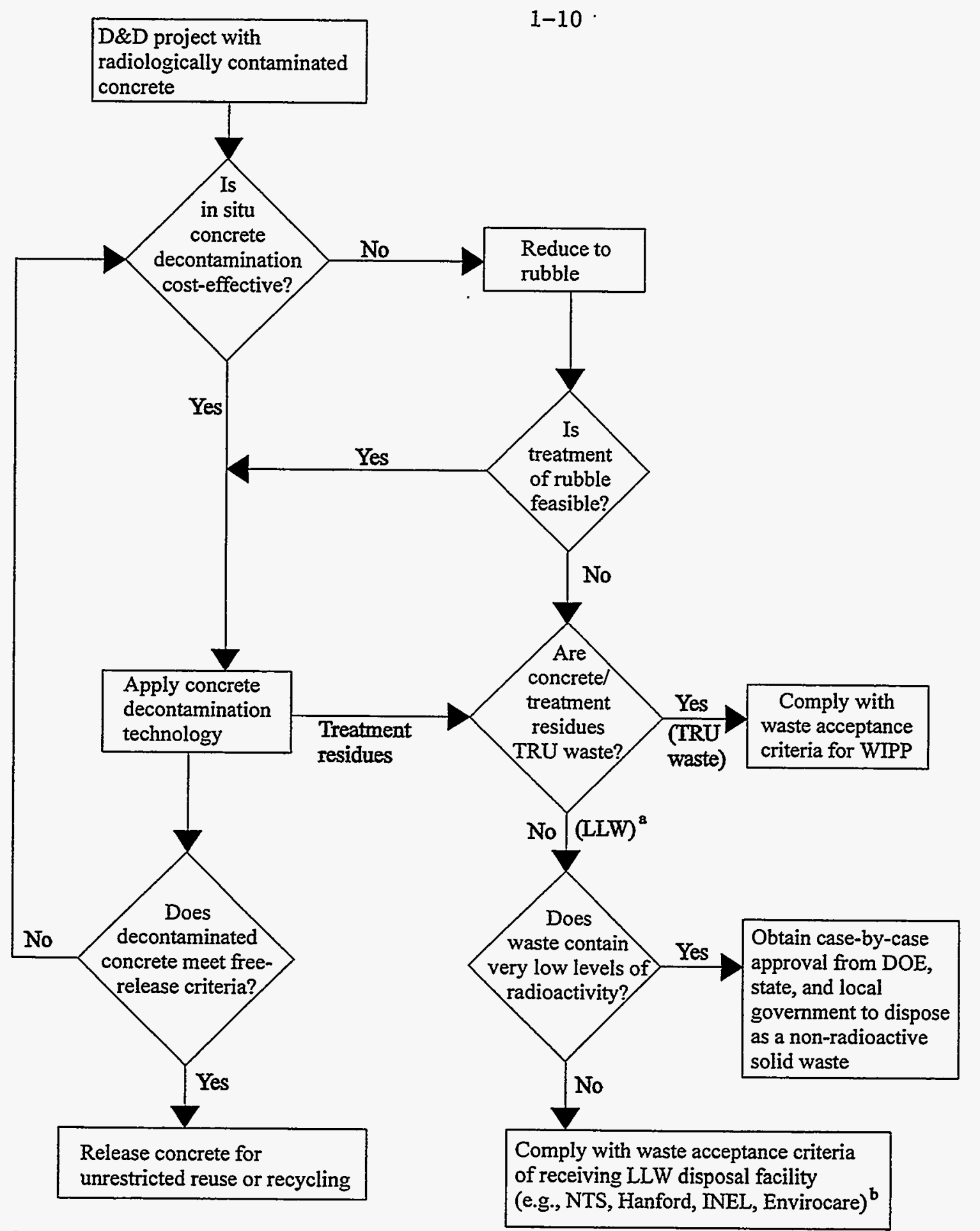

It is assumed that the concrete and treatment residues will either be classified as TRU waste or LLW.

b Other restricted uses for radiologically contaminated concrete may be possible, such as LLW disposal vauits and/or containers or a solidification agent for other radioactive waste.

Fig. 1.3. Regulatory Iogic flow diagram. 
Table 1.3. Generic guidelines for residual radionuclides in soil

\begin{tabular}{|c|c|c|}
\hline Radionuclide & Criteria & Comments \\
\hline${ }^{226} \mathrm{Ra},{ }^{228} \mathrm{Ra},{ }^{230} \mathrm{Th}$, and ${ }^{232} \mathrm{Th}$ & $\begin{array}{l}5 \mathrm{pCi} / \mathrm{g} \text { (averaged over the first } 15 \mathrm{~cm} \text { of soil below the } \\
\text { surface). } \\
15 \mathrm{pCi} / \mathrm{g} \text { (averaged over } 15 \text {-cm-thick layers of soil } \\
\text { more than } 15 \mathrm{~cm} \text { below the surface). }\end{array}$ & $\begin{array}{l}\text { The residual concentrations provided assumes } \\
\text { secular equilibrium. If the radionuclides are } \\
\text { not in secular equilibrium, the appropriate } \\
\text { guideline is applied as a limit for the radio- } \\
\text { nuclide with the higher concentration. }\end{array}$ \\
\hline Other radionuclides & $\begin{array}{l}\text { Residual concentrations shall be derived from the basic } \\
\text { dose limits by means of an environmental pathway } \\
\text { analysis using specific property data where available. }\end{array}$ & \\
\hline $\begin{array}{l}\text { Hot spots (for areas equal to or } \\
\text { less than } 25 \mathrm{~m}^{2} \text { ) }\end{array}$ & $\begin{array}{l}\text { Residual concentration shall not exceed the radionu- } \\
\text { clide soil limit times }(100 / \mathrm{A})^{0.5} \text {, where } \mathrm{A} \text { is the area in } \\
\text { square meters. Reasonable efforts shall be made to } \\
\text { remove any source of radionuclides that exceed } 30 \\
\text { times the limit, regardless of the average concentration } \\
\text { in soil. }\end{array}$ & $\begin{array}{l}\text { If average concentration exceeds the } \\
\text { radionuclide soil limit times }(100 / \mathrm{A})^{0.5} \\
\text { DOE/CH- } 8901 \text { shall be used to calculate } \\
\text { hot spot limits. }\end{array}$ \\
\hline Mixtures of radionuclides & $\begin{array}{l}\text { The dose for the mixtures will not exceed the basic dose } \\
\text { limit, or the sum of the ratios of the soil concentration } \\
\text { of each radionuclide to the allowable limit for that } \\
\text { radionuclide will not exceed l. }\end{array}$ & $\begin{array}{l}\text { Explicit formulas for calculating residual } \\
\text { concentration guidelines for mixtures are given } \\
\text { in DOE/CH-8901. }\end{array}$ \\
\hline
\end{tabular}

Source: DOE Order 5400.5 (U.S. DOE 1990) 


\section{Nature and Extent of Concrete Contamination}

\subsection{Introduction}

This section provides an overview of the amount and type of contaminated concrete that exists throughout the DOE complex based on available information. The sources of information used to describe the contamination are provided.

Concrete was used widely in the construction of DOE facilities because of its structural strength, shielding qualities, and reasonable cost. It is estimated that there are approximately 1000 facilities currently identified in the DOE complex that will require decommissioning, with costs in the tens of billions of dollars (Murphie 1992). Consequently, DOE has identified contaminated concrete as a major decontamination problem with a high priority for disposition (U.S. DOE 1993a).

Facilities may be at any one of four phases of D\&D: (1) assessment, (2) development, (3) operations, and (4) close-out (U.S. DOE 1993a). It is important to note that not all of the concrete contamination that exists within the DOE complex has been assessed, usually because of current, existing operations. Therefore, the information presented represents the best available data at the time of report preparation. As characterization of contaminated concrete continues, more site-specific and detailed information will become available.

\subsection{Methods}

Description of the nature and extent of contaminated concrete in the DOE complex was completed through various information-gathering activities. These included the acquisition of numerous sources describing site histories and the characterization of contaminated concrete at DOE facilities. Table 2.1 lists all of the sites for which information was obtained. Various data bases and both phone and written inquiries of knowledgeable staff at the individual DOE sites produced this information.

\subsubsection{Literature Searches}

An extensive literature search provided information regarding concrete $D \& D$ case studies as well as general information on contaminated concrete and needs for decontamination. The following sources were among those used: (1) the EPA record of decision data base, (2) the EPA Alternative Treatment Technology Information Center (ATTIC) data base, (3) the EPA Online Library System, (4) the DOE Remedial Action Program Information Center (RAPIC) data base, and (5) DIALOG, a commercial information service. 
Past experience of the NRC in reactor decommissioning contributed the majority of lessons learned in concrete decontamination. Available documentation from experience at DOE, the U.S. Department of Defense, and EPA sites was acquired. Case studies were evaluated and are discussed in Sect. 2.3.1.

\subsubsection{Surplus Facility Inventory and Assessment (SFIA) Data Base}

The SFIA project of the Office of Facility Transition and Management (EM-60) developed a data base to define the magnitude of the DOE contaminated surplus asset inventory (U.S. DOE 1994b). This data base provides general information regarding the types of contaminants expected at buildings declared surplus (or to be declared surplus) and scheduled for transfer to EM-40 before FY99. Both EM-60 and EM-40 facilities are included in the data base, but complete assessment information was not included for all facilities (Table 2.1). Therefore, several EM-60 and EM-40 facilities are not in the retrieved data set. For example, Oak Ridge Reservation (ORR) $\mathrm{K}-25$ is not included in the data base as containing contaminated concrete.

The search parameters used and the data set retrieved for this report are provided in Appendix B. The data base contains a total of 20,725 records consisting of 19,484 buildings (a fixed-roofed structure) and 1,241 tanks (containers for holding or storing fluids or gases, excluding mobile tanks). The entire data base is not provided in Appendix B because numerous records did not confirm radiological contamination. Since no tanks in the data base were constructed of concrete, tanks were not evaluated as part of this project.

The data set retrieved from the SFIA data base included buildings known to be processcontaminated [radiological contamination resulting from operational activities as opposed to contamination resulting from building materials such as asbestos or polychlorinated biphenyl (PCB) transformers]. Described in Appendix B, the retrieved data set includes 210 buildings where radiological contamination was identified. Hence, concrete at these facilities is likely to be radiologically contaminated. Of the 210 buildings, operations at $36 \%$ have been discontinued with no current plans to resume activities (Fig. 2.1). Thirty-three percent are buildings with operations projected to end before FY99. Twelve percent of the buildings are abandoned and have been left unattended. Three percent are being deactivated and have a status of planned, controlled, and permanent cessation of operations. Only about $2 \%$ were in the D\&D process, and $3 \%$ were in the standby status, where the buildings are maintained for possible reactivation. The remaining facilities $(11 \%)$ are at miscellaneous status. The majority of potentially contaminated concrete identified in the SFIA data base has not been thoroughly characterized at the present time, as demonstrated by the small percentage in the D\&D process. This is due, in part, to the fact that concrete frequently cannot be characterized until machinery and structures are removed from the facilities. 


\subsubsection{Baseline Environmental Remediation Report (BEMR) Data Base}

As part of a programmatic environmental impact statement (PEIS), Battelle Pacific Northwest Laboratory (PNL) compiled a data base with detailed information on DOE facilities. Currently being used to produce the BEMR, the data base is known as the BEMR data base and was valuable in providing general information pertaining to estimated areas of contaminated concrete. The BEMR data base supplemented the SFIA data base by providing additional information on EM-40 and EM-60 facilities. However, like the SFIA data base, it did not contain complete or specific information on concrete (Table 2.1). Further information about the structure of the data base and the search results is provided in Appendix B.

\subsubsection{CROSSWALK Data Base}

CROSSWALK, a data base for technology needs assessment published by Rust Geotech, Inc., for the DOE Office of Environmental Restoration (ER), was another source of site-specific needs associated with concrete decontamination. The data base was specifically designed to match technology needs with existing technologies. The information gleaned from this search was useful in providing a basis for evaluating the needs of the entire DOE complex, although some of the needs are dated and may be obsolete. Information from this source is also presented in Appendix B.

\subsubsection{Site Evaluations}

In addition to the use of data bases and literature searches, a survey of $40 \mathrm{DOE}$ sites produced personal and written responses from D\&D representatives of DOE and its contractors. This survey proved to be the most valuable information source because it supplemented and verified the information obtained from the literature and data bases (Table 2.1). Appendix A is a compilation of the detailed information from all of these sources. Appendix A also contains a sample of the interview form used to query the sites.

\subsection{Results}

As stated in Sect. 1, concrete D\&D has been identified by DOE as a major area of concern, requiring technologies that provide better and faster decontamination (U.S. DOE 1993a). Indeed, concrete was identified as the fourth most serious D\&D problem following (1) establishing de minimis levels, (2) decontamination of metals, and (3) the need for improved characterization techniques. In a technology assessment developed by DOE EM and experts from across the country, the severity of site concrete problems was ranked on a scale of 0 to 10, from no problem to major problem (Table 2.2). Sites were ranked qualitively and independently. For example, experts knowledgeable about the ORR K-25 site deemed contaminated concrete a major problem and, therefore, assigned a ranking of 10 . These rankings cannot be 
compared between sites [e.g., Paducah Gaseous Diffusion Plant (PGDP) vs Idaho National Engineering Laboratory (INEL)] because the ranking was not considered to be relative across the DOE complex but rather an indication of the severity of contaminated concrete within that site.

A large volume of documentation pertaining to the nature and extent of concrete contamination in the DOE complex was gathered (Appendices A and B). For a number of reasons, contaminant extent is site-specific in nature and difficult to generalize across the DOE complex (e.g., variety of facilities, different facility histories and uses, varying stages of characterization). However, several general trends were observed. The observations and generalizations of contaminant occurrence and potential extent of contaminated concrete are based on limited data and are not meant to be exact inventories of the entire DOE complex.

\subsubsection{Extent of Concrete Contamination}

Table 2.3 provides a summary of the generic types of facilities and the typical concrete problems associated with each type. A facility within the DOE complex is defined as a functional unit that requires D\&D (e.g., building, structure, section of a structure, containment, or equipment). The facilities are associated with the different stages of the nuclear fuel cycle and weapons production; hence, the type and level of contamination vary. Concrete with highlevel contamination (typically associated with reactors, hot-cells, fuel-fabrication, and canyon facilities) is most often dismantled and disposed of because decontamination is costly and creates a risk of increased worker exposure. If high-level contamination areas require decontamination, remote methods are typically used. (Remote decontamination methods are beyond the scope of this project and are addressed under a separate D\&D technical area.) Concrete with low-level contamination, typically found in research and development (R\&D), weapons materials production, and enrichment facilities, may be decontaminated to minimize waste disposal. Larger sites, such as ORR and the Savannah River Site (SRS), contain many types of facilities and a large variety of concrete conditions, hence the difficulty in gathering volume estimates. For nuclear reactors, general calculations indicate that approximately 3000 to 4000 tons of activated and non-activated concrete must undergo D\&D per reactor (Cornelissen and KEMA 1990).

\section{Data From BEMR Data Base}

The BEMR data base provided estimates of the total square footage and the percentage of contaminated floor space for each facility in the data base. This information was restricted to buildings and did not include containments such as basins and pools. These data are useful given the assumption that the buildings have at least as much contaminated concrete as the estimated percent of contamination. The concrete thickness of the walls and ceilings was considered in the reported percent of contamination, but an exact volume of concrete was not available. Furthermore, characterization at many sites is in the early stages, and data 
were not available for inclusion into the data base. Therefore, estimates in the BEMR data base do not completely reflect the extent of contaminated concrete throughout the DOE complex.

A total of all the buildings with available information were evaluated, representing an estimated 0.79 billion $\mathrm{ft}^{2}$ of potentially contaminated concrete (Table 2.4). This estimate is equivalent to approximately 18,000 acres of contaminated concrete. Although many unknowns are associated with this estimate, it provides an order-of-magnitude estimation of the extent of contaminated concrete. While it is likely that the sites with the largest contaminated areas will have large volumes of contaminated concrete, ranking based on area of potential contaminated floor [i.e., Hanford Site (HANF) > ORR Y-12] is not possible because information is not available for all sites (e.g., PORTS). Larger sites that have incomplete data available in the data base (i.e., INEL, ORR K-25) are expected to exceed the largest single current estimate.

\section{Data from Site Queries}

Information from site queries, presented in Appendix A and summarized in Table 2.5, generally agrees with the BEMR data base on which sites have the largest extent of contaminated concrete. However, the order of sites identified as having the largest amount of concrete contamination varies. For example, site queries indicated that the top five sites were Fernald Environmental Management Project (FEMP), HANF, ORR K-25, Lawrence Berkeley Laboratory (LBL), and INEL. That LBL is surprisingly in this category is attributed to the fact that LBL provided contaminant extent estimates while other larger sites reported the estimated extent as undefined [e.g., Paducah (PGDP), ORNL, SRS]. Thus, given the available information from both the BEMR data base and site queries, sites cannot be accurately ranked based on the extent of contamination. However, these data are useful for identifying broad estimates of the extent of contaminated concrete by indicating where the problem is most prevalent in the DOE complex.

Information from site representatives at HANF indicates that $-37,000 \mathrm{ft}^{3}$ of contaminated concrete in reactor facilities are associated with the 100 Area and $\sim 1.7 \times 10^{6} \mathrm{ft}^{3}$ with the 200 Area. A volume estimate was not available for the 300 Area; however, the current totals are enough to show that HANF has large quantities of contaminated concrete. Concrete contamination in the 100 Area consists of fission products in retention and fuel-storage basins. Other concrete contamination is associated with spills of petrochemicals and hazardous materials. Concrete contamination in the 200 Area consists of transuranic (TRU) elements, nitrates, and metals on the tops of tank domes and within valve boxes, hot cells, and process equipment bays. The HANF 300 Area is known to have concrete contaminated due to spills on floors and other concrete surfaces. In general, contaminants associated with concrete at HANF include $\mathrm{Sr}, \mathrm{Cs}, \mathrm{Pu}, \mathrm{U},{ }^{99} \mathrm{Tc},{ }^{60} \mathrm{Co},{ }^{14} \mathrm{C}, \mathrm{Am}$, and other heavy metals. 
FEMP estimates a volume of $3.3 \times 10^{6} \mathrm{ft}^{3}$ of concrete, associated primarily with floors and walls of buildings contaminated with $U$ and $T h$. Concrete will be one of the major contributors to the total waste volume at FEMP, unless decontamination can reduce the projected volume of rubble and debris.

INEL estimates $278,000 \mathrm{ft}^{3}$ of contaminated concrete and $161,000 \mathrm{ft}^{3}$ of rubble [not including the Idaho Chemical Processing Plant (ICPP), with $\sim 725,000 \mathrm{ft}^{2}$ of contaminated concrete floor space]. Considering that 52 reactors are slated for D\&D at INEL, concrete will be a major contributor to waste volume at the site.

There is no complete inventory of volumes of contaminated concrete at Y-12; however, representatives from the plant estimate that there are $153,000 \mathrm{ft}^{2}$ of floor space with known contaminants, primarily $\mathrm{Hg}, \mathrm{U},{ }^{232} \mathrm{Th}, \mathrm{Li}$, and PCBs. Indeed, as much as 250 tons of elemental mercury may contaminate Building 9401-4 and the equipment within the building. Both $\mathrm{Hg}$ and PCBs are known to contaminate concrete to depths up to 6 in., posing a challenge to decontamination at $\mathrm{Y}-12$.

Site queries at the Weldon Spring Site (WSS), Rocky Flats Environmental Technology Site (RFETS), and SRS provided general information only since detailed inventories of contaminated concrete are not available at this time. These facilities undoubtedly contain large quantities of concrete contaminated with a wide range of substances. Enrichment facilities at PGDP and the Portsmouth Gaseous Diffusion Plant (PORTS), although not fully characterized, also have large volumes of potentially contaminated concrete. PGDP and PORTS will likely have concrete contamination similar to ORR K-25, currently estimated at 16.7 million $\mathrm{ft}^{2}$, which will result in approximately $500,000 \mathrm{ft}^{3}$ of rubble (Appendix A). These facilities are also subject to a variety of contaminants (primarily $U$ and ${ }^{99} \mathrm{Tc}$ ).

Finally, as previously mentioned, many sites did not have volume information available due to lack of characterization or because depths of contamination vary and precise volume estimates are unpredictable. In general, the sites did not provide information on the depth of concrete contamination. Battelle Columbus Laboratories Decommissions Project (BCL) reported that contamination depth varies from 1/16 in. to 5 to 6 in. Energy Technology Engineering Center (ETEC) reported from previous experience that contamination is generally $<1$ in. deep.

Appendix A provides more detailed information on estimated volumes and areas of contaminated concrete at DOE sites.

\subsubsection{Nature of Concrete Contamination}

The SFIA data base contained more detailed information on specific contaminants associated with each of the DOE facilities than did the BEMR data base. Search results yielded 210 records where radiological contamination was confirmed, providing information on 19 sites 
A general breakdown of radiological contaminants reported in the SFIA data base is provided in Fig. 2.2. Contaminants identified for individual sites are presented in Fig. 2.3. As with the BEMR data base, the SFIA data base does not contain complete information for all sites. This is clearly illustrated in Fig. 2.3. For example, $\mathrm{Pu}$ is not identified as a contaminant at RFETS, TRU isotopes are identified to account for $33 \%$ of the total contamination at PGDP, and ORR $\mathrm{K}-25$ is not represented. Non-radiological contaminants were not included because their presence in concrete was found to be limited and not well characterized (compared to the radiological contaminants) and may pose different decontamination issues (e.g., mixed waste). More than a quarter of the facilities did not specify the contaminant isotopes. Of the facilities identifying specific isotopes, ${ }^{137} \mathrm{Cs}$ was the most abundant, followed by ${ }^{238} \mathrm{U},{ }^{60} \mathrm{Co},{ }^{90} \mathrm{Sr}$, and tritium, all of which account for only $~ 30 \%$ of the total occurrence. It is important to note that $24 \%$ of the contaminants are listed as unknown, indicating a lack of characterization information. Furthermore, an additional $24 \%$ are classified as other contaminants: over 100 isotopes with less than $1 \%$ occurrence per isotope.

The SFIA data are slightly different from NRC research findings on contamination associated with nuclear power plants, where the most abundant long-lived radioisotopes associated with contaminated concrete for times ranging from 10 to 20 years after shutdown were ${ }^{60} \mathrm{Co},{ }^{55} \mathrm{Fe}$, ${ }^{73} \mathrm{Ni}$ and ${ }^{137} \mathrm{Cs}$ (Abel et al. 1984). In this study, contamination residues normally contained very low concentrations of ${ }^{90} \mathrm{Sr},{ }^{904} \mathrm{Nb}, \mathrm{Pu}, \mathrm{Am}$, and $\mathrm{Cm}$. However, the study was primarily of reactor facilities; DOE facilities are more diverse, as demonstrated in Table 2.3. Based on available information, it can be assumed that concrete in DOE facilities is commonly contaminated with ${ }^{137} \mathrm{Cs},{ }^{238} \mathrm{U},{ }^{60} \mathrm{Co},{ }^{90} \mathrm{Sr}$, tritium, and TRU (Fig. 2.2). Appendix B contains a detailed listing of the facilities examined in the SFIA data base and associated contaminant information.

As with the extent of contamination, the site queries (Table 2.5) generally agree with the nature of concrete contamination indicated in the SFIA data base. In addition, they provide an indication of the frequently occurring contaminants throughout the DOE complex. The SFIA and BEMR data included only general information, and information was missing from several sites (e.g., FEMP). However, the site queries, obtained from telephone interviews with site personnel, provided information that was not included in the SFIA or BEMR data bases (Appendix A).

Based on site queries, radiological contamination was more significant than non-radiological contamination. Cesium-137- and ${ }^{60} \mathrm{Co}-$ contaminated concrete associated with reactors and their supporting structures was found at Argonne National Laboratory (ANL), Brookhaven National Laboratory (BNL), ETEC, INEL, LBL, Nevada Test Site (NTS), ORNL and the West Valley Demonstration Project (WVDP). Isotopes and daughter products of uranium were concrete contaminants at BCL, FEMP, INEL support facilities, Los Alamos National Laboratory (LANL), ORR K-25, ORR Y-12, PGDP, PORTS, RFETS, and WSS. TRU contamination in concrete was reported at ETEC, HANF, INEL, LANL, Mound Plant (MND), NTS, ORNL, and RFETS. Many sites had not yet identified the contaminating 
isotopes or reported having mixed fission products, gross alpha, or gross beta. This is shown as the "Unknown" contaminants in Fig. 2.2, 24\% of the occurrence. Some sites, such as SRS, have a large array of contaminants; it is difficult to determine a "primary" contaminant at this point in time.

\subsubsection{Previous DOE Experience with Concrete Decontamination}

When evaluating the nature and extent of contaminated concrete, valuable information can be obtained from past experiences. For example, past experiences at a site may indicate that contamination was typically confined to the surface $1 / 8$ inch or that cracks and joints presented a major problem but were encountered only rarely. Additionally, useful information can be gleaned from past experience with decontamination technologies.

Information relating to past experiences in concrete decontamination was solicited from 40 sites (Table 2.1). Typically, facilities with the largest volumes of all types of contamination had undergone more D\&D activities using more diverse technologies (Table 2.6). ORR, INEL, HANF, and SRS, for example, had each tried several conventional technologies. D\&D programs at some locations were not sufficiently developed to provide information for the survey. Other facilities had not yet begun pre-D\&D site-characterization studies, usually because the sites were still active. The remainder either had no contaminated concrete or had already completed D\&D.

It should be noted that most contamination associated with concrete is surficial (within the top inch). More mobile radionuclides such as ${ }^{99} \mathrm{Tc}$ and tritium are expected to migrate deeper into the concrete than less mobile radionuclides such as ${ }^{238} \mathrm{U}$ and ${ }^{90} \mathrm{Sr}$. Also, migration of radionuclides into the concrete structure of buildings was almost completely avoided if a coating was applied to the concrete prior to a spill or contamination (Deguchi et al. 1992). However, bare concrete, concrete where the integrity of the coating is lost, or cracked and pitted concrete becomes subject to contamination at depth. Experiments with ${ }^{60} \mathrm{Co}$ indicate that radioactivity decreases rapidly with depth near the surface, however, decreasing more slowly after about 4 in. in depth (Deguchi et al. 1992). Radioactivity at a depth of about 8 in. was found to be about five orders of magnitude lower than at the surface. Cesium was found to migrate at a similar rate. In general, characterization of concrete does not include depth measurements. DOE primarily uses floor monitors and surface probes to measure exposure rates. Rarely is concrete cored and analyzed as part of D\&D scoping and characterization surveys. Therefore, information on contamination at depth is primarily from measurements taken during and after decontamination at DOE facilities.

Past experiences in concrete decontamination are summarized in Table 2.7. As previously mentioned, the effectiveness of a decontamination method is often related to the presence of sealant coatings and paint. If the concrete had a previous coating, decontamination was generally more successful than if the coatings were damaged or the concrete was bare. This 
is attributed to the fact that most contaminants will not penetrate sealants as compared to the more porous surface of concrete.

Traditional concrete decontamination methods incluḍe shot blasting, mechanical scabbling, detergent scrubbing, high-pressure washing, chemical treatments, strippable coatings, clamshell scrapers, brushing, vacuuming, and attacking cracks with jack hammers. Technologies are further described in Sect. 3.

The use of explosives, jackhammers, etc., has been a problem because of high worker exposure to contamination suspended in dust. This is well demonstrated in experiences at Mound and during the cleanup of reactors in the 1970 s.

In general, the present technology needs for concrete decontamination arise from past experience. It is also evident from past experience that (1) the primary decontamination methods used to date have been pressure-washing techniques and various types of scabbling, and (2) the majority of concrete decontamination experience is associated with the D\&D of reactors by the NRC.

\subsubsection{Concrete Contamination in Facilities under NRC Control}

The NRC has the responsibility for developing a general decommissioning policy for commercial nuclear facilities in the United States and in that role, has made major contributions to the study of concrete contamination. This section discusses some of the applicable NRC research.

Concrete contamination was included in a group of characterization studies funded by the NRC to provide guidance for decommissioning nuclear power plants (Abel et al. 1984). These studies showed that radionuclide contamination of concrete in these plants is of two types: (1) surface contamination resulting from spills of radioactive materials and (2) neutronactivated concrete in the bioshield and floor directly underneath the pressure vessel. Surface contamination of concrete was found to be extremely patchy and generally limited to areas of the plant where radioactive liquids had spilled. The most abundant radionuclides in surfacecontaminated concrete were ${ }^{137} \mathrm{Cs},{ }^{134} \mathrm{Cs}$, and ${ }^{60} \mathrm{Co}$. Relative to other radionuclides, ${ }^{137} \mathrm{Cs}$ and ${ }^{134} \mathrm{Cs}$ are preferentially sorbed onto bare concrete due to the ability of cesium to ion-exchange with mineral phases in the concrete. This behavior was mainly noted for bare concrete surfaces or surfaces that had lost their paint coatings. Concentrations of up to $3 \mu \mathrm{Ci} / \mathrm{g}$ of ${ }^{137} \mathrm{Cs}$ were observed in some of the most contaminated concrete (Abel et al. 1984).

The NRC recently produced a generic environmental impact statement (GEIS) to accompany planned rulemaking to establish radiological criteria for decommissioning NRC-licensed facilities (U.S. NRC 1994a, 1994b). These facilities include: nuclear power plants, non-power (research and test) reactors, fuel fabrication plants, uranium hexafluoride production plants, uranium mill facilities, independent spent-fuel storage installations, and non-fuel-cycle nuclear 
material facilities. Types and concentrations of radionuclides and the surface areas contaminated are given for each of several reference facility types (Table 2.8).

One of the principal decommissioning activities expected to be sensitive to residual radioactivity criteria was cleaning, removing, and disposing of contaminated concrete. Appendix $\mathrm{C}$ of the GEIS provides supportable technical models for estimating facility concrete contaminant penetration and a generic analysis of the differentials in decommissioning costs associated with decontamination to alternate residual contamination levels (U.S. NRC 1994a). This experience may prove to be very useful to $\mathrm{DOE}$ facilities during the characterization phases of D\&D.

\subsubsection{General Concrete Decontamination Technology Needs at DOE Sites}

Based on the nature and extent of contaminated concrete, DOE previously conducted a general D\&D technology assessment during which specific D\&D needs were identified for DOE facilities (U.S. DOE 1993a, 1994a). Additionally, CROSSWALK, a data base for technology needs assessment, was designed to match technology needs with existing technologies. The information gleaned from a search of the data base was useful in providing a basis for evaluating the needs of the DOE complex. However, some of the needs may be obsolete because the deadlines for technology needs at many of the sites has passed. The needs identified were both reiterated and expanded upon during the site queries (Table 2.6) and in the INEL and ORR Technology Logic Diagrams (INEL 1993, 1994; ORNL 1993; Oak Ridge K-25 Site 1993). Several problems and needs associated with in situ and ex situ concrete decontamination were identified and are outlined in the site-specific evaluations in Appendix A and summarized in Table 2.9.

\subsection{Discussion}

Concrete was widely used to build the facilities that support the nuclear fuel cycle and weapons production in the DOE complex. The concrete associated with these facilities has been found to contain a myraid of contaminants, varying from site to site depending on the facility type. The nature and extent of contaminated concrete in the DOE complex cannot be comprehensively defined until characterization of these facilities is complete. The majority of DOE sites do not have a volume inventory of contaminated concrete because they are still in active use or in the initial stages of characterization. Inventories of contaminated buildings in the SFIA and BEMR data bases suggest the potential for an enormous amount of contaminated concrete, but show that the majority of facilities are in the early assessment stage of the D\&D process. The BEMR data indicated that only $19 \%$ of the buildings in its inventory were surplus and $1 \%$ were surplus with cleanup approved. Sixty-one percent of the buildings were active. Data in the SFIA data base indicate that only $2 \%$ of the data set was in the D\&D process. Therefore, it is not surprising that approximately $40 \%$ of the sites surveyed in this study were unsure of technology selection because they were not yet at the $D \& D$ development 
phase. However, based on the amount of the floor space of contaminated buildings that have not been characterized, it is likely that concrete decontamination technology selection will be an important process in the future of DOE D\&D. Indeed, floor space in uncharacterized concrete buildings at sites such as PORTS, RFETS, and SRS may exceed the total of all concrete decontaminated to date.

The available information provides a general perspective on the nature of concrete contamination in the DOE complex. It is evident from the variety of facility types (Table 2.3) that contaminants in concrete are wide-ranging. Sources of information indicate that for sites where characterization has been conducted, radionuclides are more abundant than non-radiological contaminants in concrete. For example, the BEMR data base indicated that $86 \%$ of the known contamination associated with buildings was radiological. Non-radiological contaminants require special considerations when they occur, specifically PCBs and $\mathrm{Hg}$, which have been determined to contaminate concrete to depths of greater than 4 in. (LBL and ORR Y-12, Appendix A). This issue may be of importance in the future, when large facilities with PCB contamination undergo D\&D [see evaluation of the Kansas City Plant (KCP) in Appendix A]. Furthermore, the treatment and disposal of mixed waste may cause special concerns. In most cases, however, radiological contamination is the greatest concern.

When the occurrence of isotopes is examined, ${ }^{137} \mathrm{Cs}$ and ${ }^{238} \mathrm{U}$ and its daughters are closely followed by ${ }^{60} \mathrm{Co},{ }^{90} \mathrm{Sr}$, and tritium in frequency (Fig. 2.2). This is consistent with findings from NRC studies and experience (Table 2.8). It should be noted that there is very limited information on radionuclide concentrations in concrete from the NRC and virtually none from DOE facilities. Most data are from surface measurements of alpha, beta-gamma, and gamma radiation exposure rates. The common finding is that most concrete contamination is surficial in nature and decreases with depth (Sect 1 and Appendix A). Past D\&D experiences confirm this, where scabbling and sandblasting methods have been required only to depths of 1 in. or less during projects at ORNL, LANL, and the Three Mile Island nuclear power plant (Irving 1980). This may account for the reason that over $17 \%$ of $\mathrm{DOE}$ sites queried indicated no need for new technology or that traditional methods were satisfactory.

Although not the primary type of contamination, contamination of concrete at depth by association with cracks and joints does occur and poses one of the most difficult problems. This has been demonstrated at $\mathrm{BCL}$, where surface methods were not effective in decontaminating deep cracks (contaminants were ultimately removed by jackhammering). Experience in the $D \& D$ of reactors has also shown that traditional methods for removing deep contamination result in high worker exposure and are time-consuming and costly. Time and costs are further increased when a portion of the work must be accomplished remotely, such as at HANF and INEL. Tritium, a deeply penetrating contaminant, poses problems at SRS, LANL, and other sites (U.S. DOE 1993a). 
Probably the most common issue and need in concrete decontamination is the reduction of waste volume and secondary waste. Scabbling, while reducing the volume of concrete requiring disposition (typically $<1$ in. of slab vs the entire slab thickness), produces large amounts of contaminated rubble that must be disposed of. Pressure washing minimizes the volume of concrete for disposal, but produces large amounts of waste water. In addition, regulatory restraints may make disposal of secondary waste costly for sites; therefore, its reduction is an important need. Facilities such as FEMP, where waste must be shipped off site, have an economic interest in reducing the volume of final waste (it is estimated that $3.3 \times 10^{6} \mathrm{ft}^{3}$ of concrete at FEMP requires decontamination) (Appendix A). LANL, in addition to exploring the costly option of disposing of concrete rubble off site, is also considering decontamination of rubble for reuse as construction aggregate. Experience at LBL demonstrates the value of recycling and reusing contaminated rubble in waste containers. Concrete rubble from LBL will be shipped to ORR and pulverized for re-use as aggregate in new concrete for waste burial boxes. Rebar in the LBL concrete will be cut and ground into small fibers and reintroduced into the new concrete matrix as a strengthening material.

Concrete decontamination was a topic in the Waste Recycling Workshop held by the Alliance of Ohio Universities and FEMP in 1994 (AOU 1994). A major conclusion from the workshop was that recycled concrete might best be used within the DOE complex. This is based on the difficulty of proving that concrete rubble is clean and the lack of applicable standards. Also, decontamination of rubble might not be economical for sites where on-site waste burial is available and associated costs are low, such as NTS or INEL. Finally, it should be noted that $.71 \%$ of DOE waste management costs are associated with the disposal of contaminated metals and concrete (Allen et al. 1988). Major cost savings could be realized by substantially reducing waste volumes.

Another need associated with secondary waste is the reduction of liquid waste associated with pressure washing and chemical methods. As an example, secondary waste produced by decontamination efforts at the ICPP produced large amounts of radioactive, sodium-bearing liquid waste that posed a disposal problem for the facility (Appendix A). Furthermore, the generation of mixed wastes produced by the use of solvents and acids used for decontamination have posed disposal problems at sites such as ORR K-25 (Appendix A). Experience with pressure washing at HANF has resulted in large amounts of liquid waste associated with this method (Appendix A).

As indicated by Table 2.2, site representatives perceive concrete contamination as a problem with varying severity at their respective sites. ORR K-25, PGDP, and PORTS all rated the problem as the most severe. Indeed, these enrichment facilities will likely present a large portion of the concrete decontamination challenges in the future. Other facilities may have rated concrete as a lower priority compared to the severity of other problems.

Finally, variations of concrete scabbling have been the most common methods of decontamination. The bulk of technology demonstrations and associated needs for new technologies have 
occurred at the larger sites, such as INEL and ORR, where characterization is in the final stages. These sites also have detailed logic diagrams for technology selection and detailed inventories of waste. These facilities should not be labeled as having the largest "concrete problem" since most facilities are in early characterization stages and do not have the information available.

\subsection{Conclusions}

The results of this work have provided a broad perspective on the nature and extent of contaminated concrete throughout the DOE complex. Assimilation and evaluation of existing information obtained from the SFIA, BEMR, and CROSSWALK data bases and personal communication with $D \& D$ representatives at the majority of the sites provided insight to the primary occurrence of contaminants and the locations with the greatest extent of contaminated concrete. Because concrete characterization is in initial stages at many sites, the available information is incomplete. Assimilation of all this information into one location, as provided in this report, is helpful in identifying topics that require more data and potential areas of concern in the future. The following are conclusions from this effort:

- The most frequently reported contaminants are ${ }^{137} \mathrm{Cs}$ and ${ }^{238} \mathrm{U}$ and its daughters, closely followed by ${ }^{60} \mathrm{Co},{ }^{90} \mathrm{Sr}$, and tritium. Approximately $24 \%$ of the contaminants identified during characterization are estimated to occur less than $1 \%$ of the time. Because characterization information is not available for several sites (including the gaseous diffusion plants), the order of the frequency of these contaminants is expected to change. For example, ${ }^{238} \mathrm{U}$ may occur more often than ${ }^{137} \mathrm{Cs}$. However, it is expected that ${ }^{137} \mathrm{Cs},{ }^{60} \mathrm{Co}$, ${ }^{238} \mathrm{U},{ }^{90} \mathrm{Sr}$, and tritium will remain the most commonly occurring contaminants within the DOE complex.

- The total area of contaminated concrete within the DOE complex is estimated to be in the range of $7.9 \times 10^{8} \mathrm{ft}^{2}$ or approximately 18,000 acres. The volume of contaminated concrete is estimated at $6.7 \times 10^{6} \mathrm{ft}^{3}$. These estimates do not represent the complete extent of contamination because they are based on incomplete and differing data available from the sites. The sites identified as having the most contaminated concrete are HANF, FEMP, and ORR. These estimates are assumed to be low because they do not include complete information from INEL, SRS, PORTS, PGDP, and RFETS, all of which are expected to have similar amounts of contaminated concrete.

- Concrete decontamination needs were identified as: (1) reduction of secondary waste (rubble and liquid), (2) cost- and schedule-effective technologies, (3) more efficient removal of the concrete surface layer, (4) innovative technologies for floor and wall decontamination, and (5) unknown. When sites were asked which decontamination problems they faced, most replied with "unknown". This is attributed to the fact that D\&D planning and implementation is still in preliminary stages at many sites. 
Table 2.1. Listing of sites for which concrete contamination data were found

\begin{tabular}{|c|c|c|c|c|}
\hline Site Name & Site Code & SFIA $^{a}$ & $\mathrm{BEMR}^{b}$ & Queried $^{c}$ \\
\hline Ames Laboratory, Iowa & AMES & $\mathrm{Y}$ & $Y$ & \\
\hline $\begin{array}{l}\text { Argonne National Laboratory } \\
\text { East, Illinois }\end{array}$ & ANLE & $Y$ & $\mathrm{Y}$ & \\
\hline $\begin{array}{l}\text { Argonne National Laboratory } \\
\text { West, Idaho }\end{array}$ & ANLW & $\mathrm{Y}$ & $Y$ & $\mathrm{Y}$ \\
\hline $\begin{array}{l}\text { Battelle Columbus Laboratories } \\
\text { Decommissions Project, Ohio }\end{array}$ & BCL & & $\mathrm{Y}$ & $\mathrm{Y}$ \\
\hline $\begin{array}{l}\text { Bettis Atomic Power Laboratory, } \\
\text { Pennsylvania }\end{array}$ & BAPL & $\mathrm{Y}$ & & \\
\hline $\begin{array}{l}\text { Brookhaven National Laboratory, } \\
\text { New York }\end{array}$ & BNL & $\mathrm{Y}$ & $\mathrm{Y}$ & $\mathrm{Y}$ \\
\hline $\begin{array}{l}\text { Colonie Interim Storage Site, } \\
\text { New York }\end{array}$ & CISS & & & $\mathrm{Y}$ \\
\hline $\begin{array}{l}\text { Energy Technology Engineering } \\
\text { Center, California }\end{array}$ & ETEC & $\mathrm{Y}$ & $\mathrm{Y}$ & $\mathrm{Y}$ \\
\hline $\begin{array}{l}\text { Fernald Environmental } \\
\text { Management Project Ohio }\end{array}$ & FEMP & & $\mathrm{Y}$ & $\mathrm{Y}$ \\
\hline General Atomics, California & GA & & $\mathrm{Y}$ & $\underline{Y}$ \\
\hline $\begin{array}{l}\text { Grand Junction Projects Office, } \\
\text { Colorado }\end{array}$ & GJPO & $\mathrm{Y}$ & $\mathrm{Y}$ & $Y$ \\
\hline Hanford Site, Washington & HANF & $\mathrm{Y}$ & $Y$ & $\mathrm{Y}$ \\
\hline $\begin{array}{l}\text { Idaho National Engineering } \\
\text { Laboratory, Idaho }\end{array}$ & $\mathbb{I N E L}$ & $\mathrm{Y}$ & $\mathrm{Y}$ & $\mathrm{Y}$ \\
\hline $\begin{array}{l}\text { Inhalation Toxicology Research } \\
\text { Institute, New Mexico }\end{array}$ & ITRI & $\mathrm{Y}$ & $\mathrm{Y}$ & $Y$ \\
\hline Kansas City Plant Missouri & $\mathrm{KCP}$ & $Y$ & $\underline{Y}$ & $\underline{Y}$ \\
\hline $\begin{array}{l}\text { Knolls Atomic Power Laboratory, } \\
\text { Kesselring and Schenectady, } \\
\text { New York }\end{array}$ & KAPL-K and S & $\mathrm{Y}$ & & $\mathrm{Y}$ \\
\hline $\begin{array}{l}\text { Laboratory for Energy-Related } \\
\text { Health Research, California }\end{array}$ & LEHR & & $Y$ & \\
\hline $\begin{array}{l}\text { Lawrence Berkeley Laboratory, } \\
\text { California }\end{array}$ & LBL & $\mathrm{Y}$ & $Y$ & $Y$ \\
\hline $\begin{array}{l}\text { Lawrence Livermore National } \\
\text { Laboratory, California }\end{array}$ & LLNL & $\mathrm{Y}$ & $\mathrm{Y}$ & $\mathrm{Y}$ \\
\hline $\begin{array}{l}\text { Los Alamos National Laboratory, } \\
\text { New Mexico }\end{array}$ & LANL & $Y$ & $\mathrm{Y}$ & $\mathrm{Y}$ \\
\hline
\end{tabular}


Table 2.1. (continued)

\begin{tabular}{|c|c|c|c|c|}
\hline Site Name & Site Code & $\mathrm{SFIA}^{a}$ & $\mathrm{BEMR}^{b}$ & Queried $^{c}$ \\
\hline Mound Plant, Ohio & MND & $Y$ & $\mathrm{Y}$ & $Y$ \\
\hline Nevada Test Site, Nevada & NTS & $Y$ & $Y$ & $Y$ \\
\hline Oak Ridge Reservation, Tennessee & ORR & & & \\
\hline Oak Ridge National Laboratory & ORNL & $\mathrm{Y}$ & $\mathrm{Y}$ & $\mathrm{Y}$ \\
\hline K-25 Site & $\mathrm{K}-25$ & & $\mathrm{Y}$ & $\mathrm{Y}$ \\
\hline Y-12 Plant & $\mathrm{Y}-12$ & $\mathrm{Y}$ & $\mathrm{Y}$ & $\mathrm{Y}$ \\
\hline $\begin{array}{l}\text { Pacific Northwest Laboratory, } \\
\text { Washington }\end{array}$ & PNL & & & $\mathrm{Y}$ \\
\hline $\begin{array}{l}\text { Paducah Gaseous Diffusion Plant, } \\
\text { Kentucky }\end{array}$ & PGDP & $\mathrm{Y}$ & $\mathrm{Y}$ & $\mathrm{Y}$ \\
\hline$\underline{\text { Pantex Plant, Texas }}$ & PANT & $\underline{Y}$ & $\mathrm{Y}$ & $Y$ \\
\hline$\underline{\text { Pinellas Plant, Florida }}$ & PINP & $\underline{Y}$ & $Y$ & $\mathrm{Y}$ \\
\hline $\begin{array}{l}\text { Portsmouth Gaseous Diffusion } \\
\text { Plant, Ohio }\end{array}$ & PORTS & $\mathrm{Y}$ & $Y$ & $\mathrm{Y}$ \\
\hline $\begin{array}{l}\text { Princeton Plasma Physics } \\
\text { Laboratory, New Jersey }\end{array}$ & PPPL & $\mathrm{Y}$ & $Y$ & $Y$ \\
\hline RMI Titanium, Inc., Ohio & RMIT & & & $Y$ \\
\hline $\begin{array}{l}\text { Rocky Flats Environmental } \\
\text { Technology Site, Colorado }\end{array}$ & RFETS & $\mathrm{Y}$ & $\mathrm{Y}$ & $Y$ \\
\hline $\begin{array}{l}\text { Sandia National Laboratories, } \\
\text { Califomia and New Mexico }\end{array}$ & SNLL & $\mathrm{Y}$ & $\mathrm{Y}$ & $Y$ \\
\hline $\begin{array}{l}\text { Savannah River Site, } \\
\text { South Carolina }\end{array}$ & SRS & $\mathrm{Y}$ & $\mathrm{Y}$ & $Y$ \\
\hline $\begin{array}{l}\text { Waste Isolation Pilot Plant, } \\
\text { New Mexico }\end{array}$ & WIPP & $\mathrm{Y}$ & & \\
\hline Weldon Spring Site, Missouri & wss & & $\mathrm{Y}$ & $Y$ \\
\hline $\begin{array}{l}\text { West Valley Demonstration } \\
\text { Project, New York }\end{array}$ & WVDP & $\mathrm{Y}$ & & $Y$ \\
\hline
\end{tabular}


Table 2.1. (continued)

\begin{tabular}{|c|c|c|c|}
\hline Site Name & SFIA & $\mathrm{BEMR}^{b}$ & Queried $^{c}$ \\
\hline \multicolumn{4}{|l|}{ Other: } \\
\hline Aberdeen & & & $\mathrm{Y}$ \\
\hline Fermi National Accelerator Laboratory & $\mathrm{Y}$ & $\mathrm{Y}$ & \\
\hline Hallam Nuclear Power Plant & & $\mathrm{Y}$ & Y \\
\hline New Brunswick Laboratory & & & $Y$ \\
\hline Oak Ridge Institute of Science and Environment & Y & & $\mathrm{Y}$ \\
\hline Piqua Nuclear Power Facility & & $\mathrm{Y}$ & \\
\hline Shippingport Station & & & $\mathrm{Y}$ \\
\hline Stanford Linear Accelerator Center (SLAC) & $\mathrm{Y}$ & $\mathrm{Y}$ & $Y$ \\
\hline Vallecitos Nuclear Center & & $\mathrm{Y}$ & \\
\hline
\end{tabular}

$Y=$ concrete contamination data were found

Note: Other sites are contained in the SFIA and BEMR data bases but are not listed here because they did not include any information on concrete.

a Surplus Facility Inventory and Assessment data base

b Baseline Environmental Remediation Report data base

- Site was contacted by phone and/or written inquiry. 

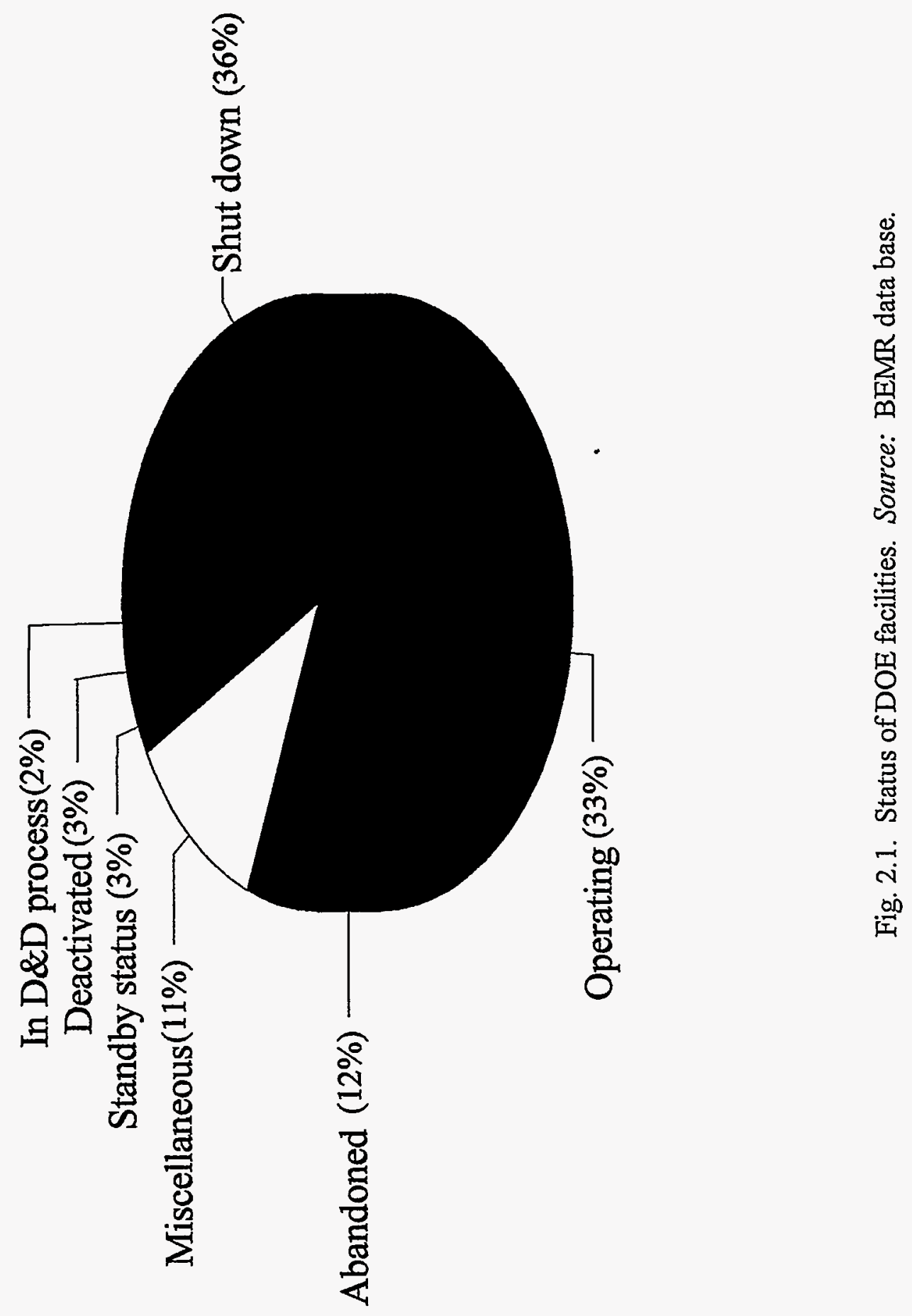
Table 2.2. Ranking of concrete problems at $\mathrm{DOE}$ facilities

\begin{tabular}{lc}
\hline Site & Ranking \\
\hline \hline ORR, K-25 & 10 \\
\hline PGDP & 10 \\
\hline PORTS & 10 \\
\hline HANF & 9 \\
\hline ORR, Y-12 & 9 \\
\hline ANLE & 8 \\
\hline ETEC & 8 \\
\hline ORNL & 8 \\
\hline LANL & 7 \\
\hline FUSRAP & 6 \\
\hline FEMP & 6 \\
\hline INEL & 6 \\
\hline SRS & 6 \\
\hline LLNL & 5 \\
\hline MND & 5 \\
\hline WSS & 3 \\
\hline \hline
\end{tabular}

Source: U.S.DOE 1993a 

Table 2.3. Concrete contamination in DOE facilities

\begin{tabular}{|c|c|c|}
\hline $\begin{array}{c}\text { Facility type } \\
\text { (site examples) }\end{array}$ & Description of concrete contamination & Decontamination comments \\
\hline $\begin{array}{l}\text { Reactors } \\
\text { (ANL, HANF, INEL, SRS, ORNL, } \\
\text { ETEC, LANL, LLNL) }\end{array}$ & $\begin{array}{l}\text { HLR (activated) in reactor vessel walls and internals, } \\
\text { biological shields, and beam tubes/ports. }\end{array}$ & $\begin{array}{l}\text { Remote methods required for non-activated HLR; } \\
\text { radiological contamination often remains after } \\
\text { surface decontamination is performed. }\end{array}$ \\
\hline $\begin{array}{l}\text { Canyon buildings } \\
\text { (HANF, SRS) }\end{array}$ & $\begin{array}{l}\text { HLR compounded by spills and leaks; wide variety of } \\
\text { potential contaminants in the concrete structure of the } \\
\text { canyon. }\end{array}$ & $\begin{array}{l}\text { Remote methods required; large volumes of concrete } \\
\text { produced for deposal. }\end{array}$ \\
\hline $\begin{array}{l}\text { Separation facilities } \\
\text { (ETEC, HANF, LANL, ORNL) }\end{array}$ & $\begin{array}{l}\text { HLR associated with structure; wide variety of } \\
\text { contaminants; similar to canyon facilities. }\end{array}$ & Remote methods required. \\
\hline Fuel fabrication facilities & $\begin{array}{l}\text { LLR and hazardous material associated with concrete } \\
\text { floors and walls and widely dispersed material (fines) } \\
\text { associated with concrete structures. Possibility of } \\
\text { creating a critical mass. }\end{array}$ & $\begin{array}{l}\text { High worker exposure; alpha contamination and } \\
\text { criticality control are major considerations. }\end{array}$ \\
\hline $\begin{array}{l}\text { Fuel reprocessing facilities } \\
\text { (HANR, ORNL, SRS, INEL) }\end{array}$ & HLR from fissile production material. & $\begin{array}{l}\text { Selection of decontamination method difficult due to } \\
\text { wide variety of potential contaminants. Selection } \\
\text { dependent on physical structure housing the facility. }\end{array}$ \\
\hline $\begin{array}{l}\text { Hot cells } \\
\text { (INEL, PNL, ORNL, SRS, ANLE) }\end{array}$ & $\begin{array}{l}\text { HLR associated with walls of hot cells and embedded in } \\
\text { cell drains and ventilation systems. }\end{array}$ & $\begin{array}{l}\text { Remote methods required; embedded drains difficult } \\
\text { to access. }\end{array}$ \\
\hline $\begin{array}{l}\text { Analytical and R\&D facilities } \\
\text { (ORNL, LANL) }\end{array}$ & LLR for the most part associated with floors and walls. & $\begin{array}{l}\text { A wide range of equipment must be removed before } \\
\text { decontamination of concrete. }\end{array}$ \\
\hline $\begin{array}{l}\text { Weapons materials production facilities } \\
\text { (Y-12, FEMP, FUSRAP, LANL, INEL) }\end{array}$ & $\begin{array}{l}\text { LLR alpha-emitting contamination (machining waste) } \\
\text { associated with floors and walls. Tritium is present at } \\
\text { some sites and penetrates deeply into concrete. }\end{array}$ & $\begin{array}{l}\text { Methods needed that penetrate deeply to reach } \\
\text { tritium and mercury contamination. }\end{array}$ \\
\hline $\begin{array}{l}\text { Uranium enrichment facilities } \\
\text { (ORR } \mathrm{K} 25, \text { PORTS, PGDP) }\end{array}$ & $\begin{array}{l}\text { LLR; U and }{ }^{99} \mathrm{Tc} \text { fluorides and oxyfluorides and } \\
\text { hazardous materials associated with floors and walls. }\end{array}$ & $\begin{array}{l}\text { Facilities are large, with enormous amounts of } \\
\text { concrete for potential decontamination; most of } \\
\text { these facilities are in the characterization process. }\end{array}$ \\
\hline
\end{tabular}

HLR: high-level radiation

LLR: low-level radiation

R\&D: research and development

Source: U.S. DOE 1993b 
Table 2.4. Estimated floor contamination in DOE facilities as reported in the BEMR data base

\begin{tabular}{lcc}
\hline \hline & $\begin{array}{c}\text { Installation } \\
\text { Number of } \\
\text { buildings }\end{array}$ & $\begin{array}{c}\text { Estimate of } \\
\text { contaminated floor } \\
\text { space, } \mathrm{f}^{2}\end{array}$ \\
\hline \hline Argonne National Laboratory East & 38 & $1.9 \times 10^{7}$ \\
\hline Argonne National Laboratory West & 1 & $2.5 \times 10^{5}$ \\
\hline Brookhaven National Laboratory & 24 & $2.0 \times 10^{7}$ \\
\hline Energy Tech Engineering Center, Area IV & 9 & $6.9 \times 10^{5}$ \\
\hline Formally Utilized Site Remedial Action Program & 6 & $1.5 \times 10^{7}$ \\
\hline Hanford Reservation & 181 & $2.5 \times 10^{8}$ \\
\hline Idaho National Engineering Laboratory & 108 & $7.0 \times 10^{6}$ \\
\hline Inhalation Toxicology Research Institute & 1 & $6.8 \times 10^{4}$ \\
\hline Kansas City Plant & 1 & $2.2 \times 10^{5}$ \\
\hline Lawrence Berkeley Laboratory & 3 & $2.7 \times 10^{5}$ \\
\hline Lawrence Livermore National Laboratory & 7 & $3.5 \times 10^{6}$ \\
\hline Los Alamos National Laboratory & 16 & $5.7 \times 10^{6}$ \\
\hline Mound Plant & 4 & $2.9 \times 10^{6}$ \\
\hline Nevada Test Site & 3 & $4.8 \times 10^{6}$ \\
\hline Oak Ridge Gaseous Diffusion Plant, K-25 & 4 & $1.6 \times 10^{6}$ \\
\hline OakRidge National Laboratory (X-10) & 79 & $2.6 \times 10^{7}$ \\
\hline Paducah Gaseous Diffusion Plant & 11 & $3.5 \times 10^{7}$ \\
\hline Pantex Plant & 3 & $8.5 \times 10^{4}$ \\
\hline Portsmouth Uranium Enrichment Complex & 1 & $2.3 \times 10^{6}$ \\
\hline Rocky Flats Environmental Technology Site & 37 & $8.5 \times 10^{7}$ \\
\hline Sandia National Laboratory, Albuquerque & 8 & $4.5 \times 10^{6}$ \\
\hline Savannah River Site & 71 & $5.2 \times 10^{7}$ \\
\hline Stanford Linear Accelerator Center & 1 & $2.3 \times 10^{5}$ \\
\hline Weldon Spring Site & 21 & $5.4 \times 10^{7}$ \\
\hline Y-12 Plant & 51 & $2.0 \times 10^{8}$ \\
\hline Total & 689 & $7.9 \times 10^{8}$ \\
\hline \hline
\end{tabular}

Note: Complete information was not available from all buildings at every DOE site (e.g., K-25). Therefore, estimates of area are incomplete and cannot be used to compare sites. However, this table provides an estimate of the order of magnitude of contaminated concrete within the DOE complex. 
Table 2.5. Summary of nature and extent of concrete contamination based on site queries

\begin{tabular}{|c|c|c|c|}
\hline Site & Contaminated area & $\begin{array}{l}\text { Primary radionuclide } \\
\text { contaminants }\end{array}$ & Estimated extent \\
\hline ANLE & $\begin{array}{l}\text { Containment structures, } \\
\text { rod storage area }\end{array}$ & $\mathrm{Co}, \mathrm{Cs}$, some tritium & $\begin{array}{l}1400 \mathrm{ft}^{2} \\
285 \mathrm{ft}^{3}\end{array}$ \\
\hline $\mathrm{BCL}$ & Undefined & $\begin{array}{l}\mathrm{U}, \mathrm{Th} \text {, some mixed } \\
\text { fission products }\end{array}$ & $\begin{array}{l}\text { Unknown (200,000 } \mathrm{ft}^{2} \text { to a } \\
\text { depth of } 1 / 16 \text { to } 6 \text { inches has } \\
\text { been decontaminated to date) }\end{array}$ \\
\hline BNL & $\begin{array}{l}\text { Buildings, storage tanks, } \\
\text { reactor, canals, concrete } \\
\text { surfaces surrounding duct work }\end{array}$ & $\begin{array}{l}\text { U oxide, } \mathrm{Pu} \text {, tritium, } \\
\mathrm{Co}, \mathrm{Cs}, \mathrm{Sr}, \mathrm{Fe}, \mathrm{Bi}, \mathrm{Na}\end{array}$ & $9000 \mathrm{ft}^{3}$ (reactor only) \\
\hline ETEC & Buildings, fuel storage vaults & $\begin{array}{l}\text { Co, } \mathrm{Cs}, \mathrm{Sr} / \mathrm{Y}, \mathrm{Eu}, \mathrm{U}, \\
\text { TRU, mixed fission } \\
\text { products }\end{array}$ & $\begin{array}{l}10,400 \mathrm{ft}^{2} \\
240 \mathrm{ft}^{3}\end{array}$ \\
\hline FEMP & Buildings, silos & $\mathrm{U}, \mathrm{Th}$ & $3,300,000 \mathrm{ft}^{3}$ \\
\hline GJPO & Concrete floors & $\begin{array}{l}\mathrm{U} \text { (mill tailings in } \\
\text { concrete matrix) }\end{array}$ & $300 \mathrm{ft}^{2}$ \\
\hline HANF & $\begin{array}{l}\text { Buildings (reactor and } \\
\text { support), laboratories, canyon } \\
\text { facilities, underground storage } \\
\text { tanks }\end{array}$ & $\begin{array}{l}\mathrm{Sr}, \mathrm{Cs}, \mathrm{Pu}, \mathrm{U}, \mathrm{Tc}, \mathrm{Co} \\
{ }^{14} \mathrm{C}, \mathrm{Am} \text {, others }\end{array}$ & $\begin{array}{l}1,737,000 \mathrm{ft}^{3}(100 \text { and } 200 \\
\text { areas) }\end{array}$ \\
\hline INEL & $\begin{array}{l}\text { Reactors and associated } \\
\text { structures (canals), hot cells, } \\
\text { chemical processing plants }\end{array}$ & $\begin{array}{l}\mathrm{Co}, \mathrm{Cs}, \mathrm{Eu}, \mathrm{U}, \mathrm{Sr}, \mathrm{Pu}, \\
\text { Am, others }\end{array}$ & $\begin{array}{l}278,354 \mathrm{ft}^{3}\left(161,087 \mathrm{ft}^{3}\right. \\
\text { rubble) }\end{array}$ \\
\hline $\mathrm{KCP}$ & Manufacturing buildings & No rad contamination & NA \\
\hline $\begin{array}{l}\text { ORR } \\
\mathrm{K}-25 \\
\end{array}$ & 82 facilities slated for $D \& D$ & $\mathrm{U}, \mathrm{Tc}$ & $\begin{array}{l}16,700,000 \mathrm{ft}^{2} \text { (generating } \\
\sim 500,000 \mathrm{ft}^{3} \text { rubble) }\end{array}$ \\
\hline LANL & Floors and walls, one reactor & Pu and $U$ & $6000 \mathrm{yd}^{3}=162,000 \mathrm{ft}^{3}$ \\
\hline LBL & $\begin{array}{l}\text { Concrete blocks used for } \\
\text { shielding }\end{array}$ & $\mathrm{Co}, \mathrm{Eu}$ & $500,000 \mathrm{ft}^{3}$ \\
\hline LLNL & No concrete $D \& D$ planned & $\mathrm{NA}$ & NA \\
\hline MND & Buildings & $\mathrm{Pu}$, tritium, Th, others & $\begin{array}{l}161,000 \mathrm{ft}^{3}(50,000 \text { to } \\
\left.100,000 \mathrm{ft}^{3} \text { rubble generated }\right)\end{array}$ \\
\hline NTS & Buildings & $\mathrm{U}, \mathrm{Pu}, \mathrm{Am}, \mathrm{Sr}, \mathrm{Co}$ & Undefined \\
\hline
\end{tabular}


Table 2.5. (continued)

\begin{tabular}{|c|c|c|c|}
\hline Site & Contaminated area & $\begin{array}{l}\text { Primary radionuclide } \\
\text { contaminants }\end{array}$ & Estimated extent \\
\hline $\begin{array}{l}\text { ORR } \\
\text { ORNL }\end{array}$ & $\begin{array}{l}\text { Reactors, buildings, storage } \\
\text { tanks }\end{array}$ & $\begin{array}{l}\mathrm{Cs}, \mathrm{Co}, \mathrm{Sr}, \mathrm{U}, \mathrm{Th}, \mathrm{Eu}, \\
\mathrm{Pu}, \mathrm{Am} \text {, numerous } \\
\text { others }\end{array}$ & Undefined \\
\hline PANT & $\begin{array}{l}\text { No concrete } D \& D \text { to date nor } \\
\text { planned }\end{array}$ & NA & NA \\
\hline PGDP & Buildings & $\mathrm{U}, \mathrm{Tc}$ & $\begin{array}{l}260,000 \mathrm{ft}^{2} \text { (currently in the } \\
\mathrm{D} \& \mathrm{D} \text { program) }\end{array}$ \\
\hline PINP & $\begin{array}{l}\text { No concrete } D \& D \text { to date nor } \\
\text { planned }\end{array}$ & Tritium & $\mathrm{NA}$ \\
\hline PNL & Included with Hanford & $\begin{array}{l}\text { Included with } \\
\text { Hanford }\end{array}$ & Included with Hanford \\
\hline PORTS & Buildings & $\mathrm{U}, \mathrm{Tc}$ & Undefined \\
\hline PPPL & $\begin{array}{l}\text { Tokamak fusion test reactor } \\
\text { scheduled for D\&D in } 9 / 95\end{array}$ & $\begin{array}{l}\text { Activation products, } \\
\text { some tritium }\end{array}$ & Very little D\&D planned \\
\hline RFETS & Buildings & $\mathrm{Pu}, \mathrm{U}$ & $\begin{array}{l}\text { Undefined ( } 116 \text { buildings } \\
\text { identified as contaminated) }\end{array}$ \\
\hline RMIT & Buildings & $\mathrm{U}$ & $15,000 \mathrm{ft}^{3}$ \\
\hline SNLL & D\&D delayed to FY96 & $\begin{array}{l}\text { No characterization } \\
\text { to date }\end{array}$ & Undefined \\
\hline SRS & $\begin{array}{l}\text { Reactors, canyons, fuel } \\
\text { fabrication facility, waste } \\
\text { tanks, buildings }\end{array}$ & $\begin{array}{l}\text { Tritium, } \mathrm{U}, \mathrm{Pu} \\
\text { fission products }\end{array}$ & Undefined \\
\hline WSS & Buildings & $\mathrm{U}, \mathrm{Th}$ & Undefined \\
\hline WVDP & Chemical process cell & $\mathrm{Cs}, \mathrm{Sr}, \mathrm{Am}, \mathrm{Pu}$ & $\begin{array}{l}\text { D\&D completed generating } \\
30,000 \mathrm{ft}^{3} \text { waste (plus } 7800 \mathrm{ft}^{3} \\
\text { secondary waste) }\end{array}$ \\
\hline $\begin{array}{l}\text { ORR } \\
\text { Y-12 }\end{array}$ & Buildings & $\mathrm{U}, \mathrm{Th}$ & $153,000 \mathrm{ft}^{3}$ \\
\hline TOTAL & & & $-6.7 \times 10^{6} \mathrm{ft}^{3}$ \\
\hline
\end{tabular}

Note: This table was generated from information provided in the site queries. More detailed information is presented in Appendix A.

$\mathrm{NA}=$ not applicable 


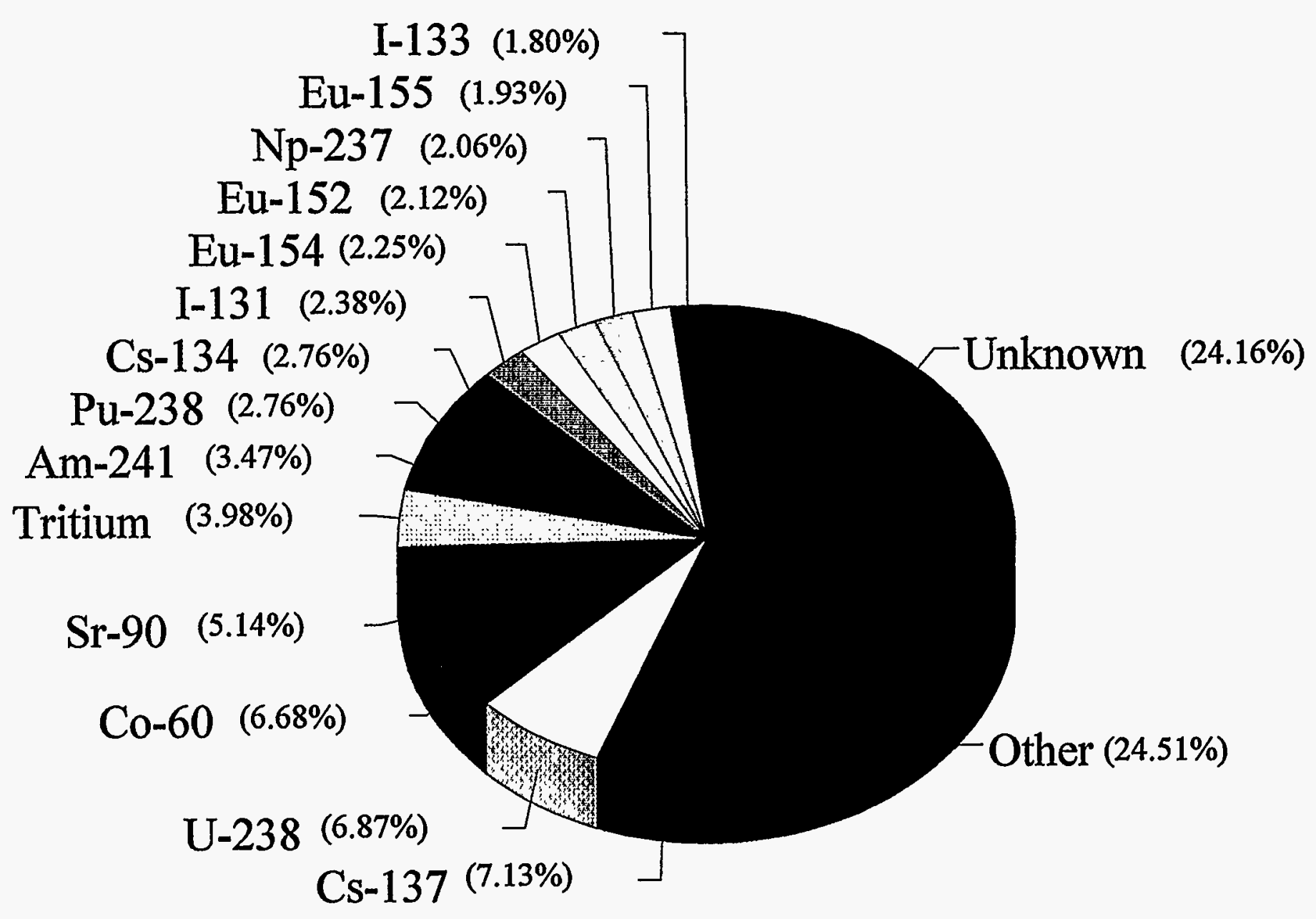

Fig. 2.2. Occurrence of contaminants representative of the DOE complex. Source: SFIA data base. 

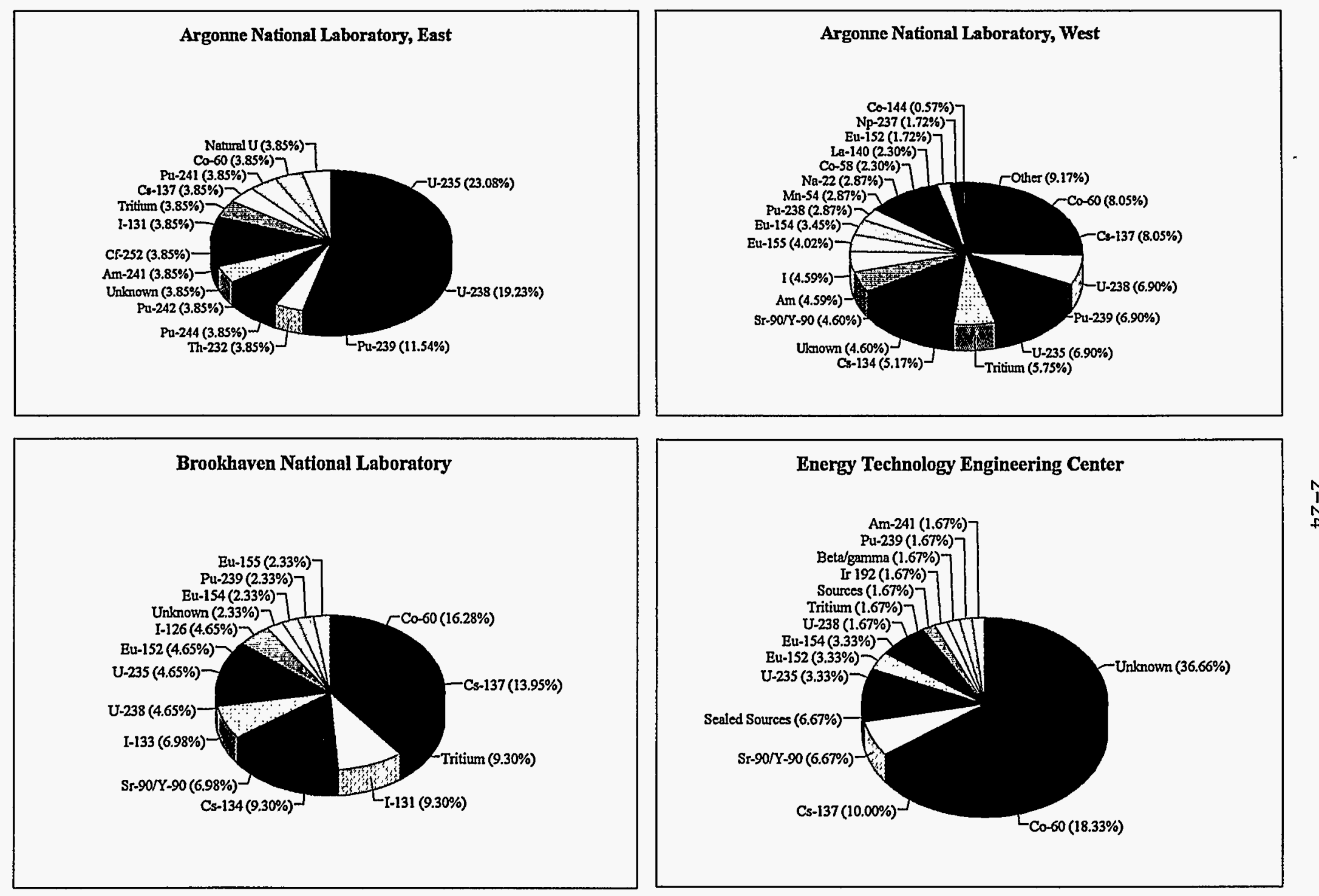

Fig. 2.3. Occurrence of contaminants at individual DOE sites. Source: SFIA data base. 


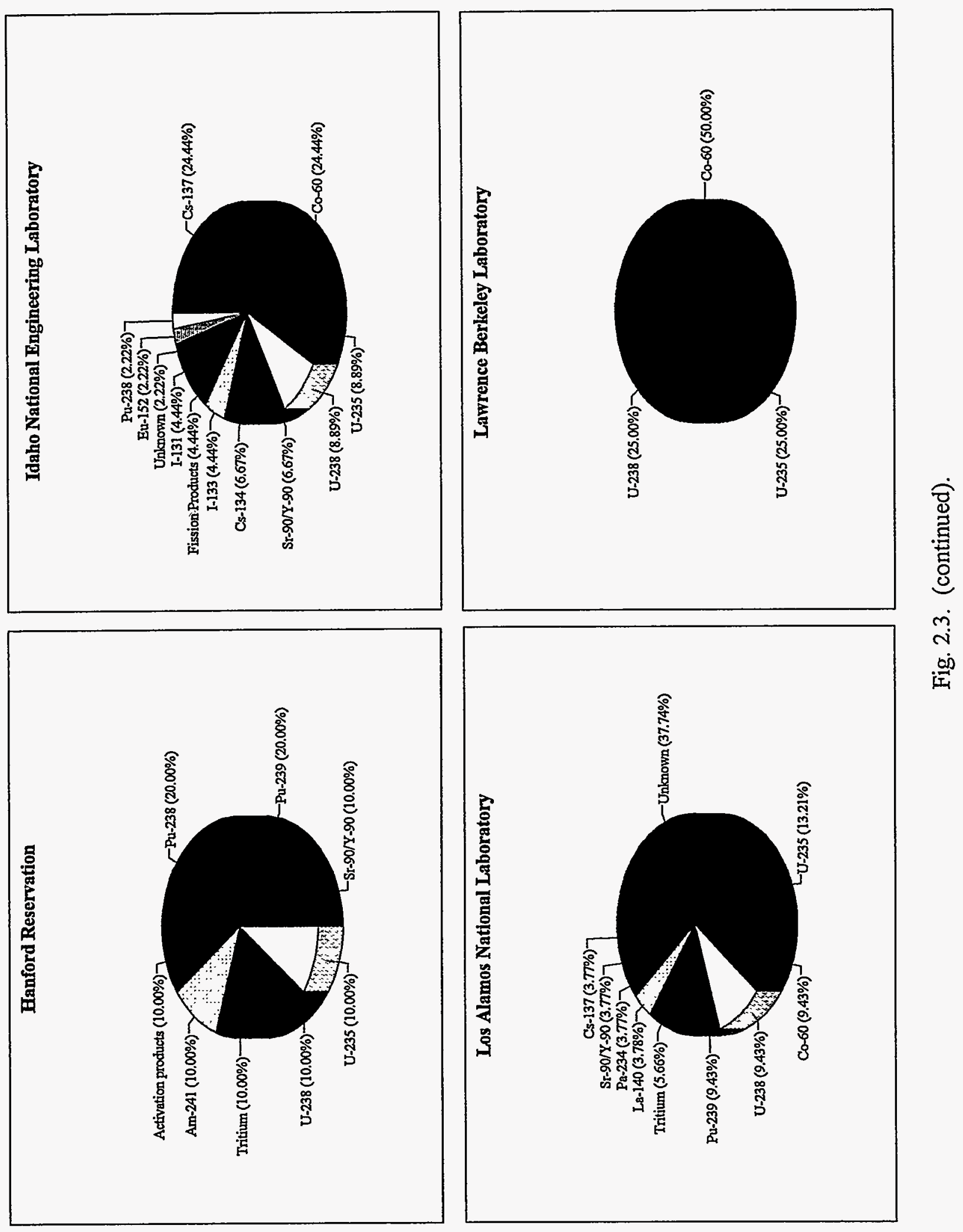


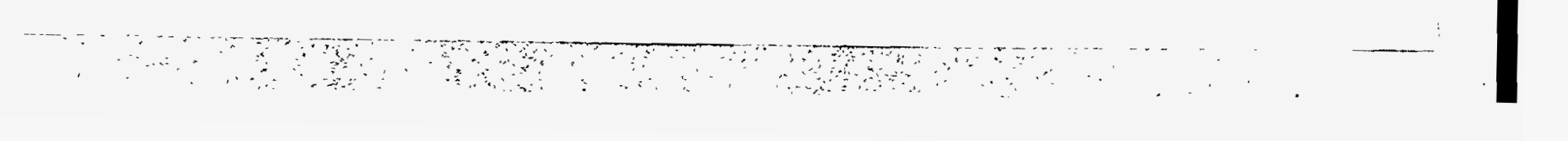



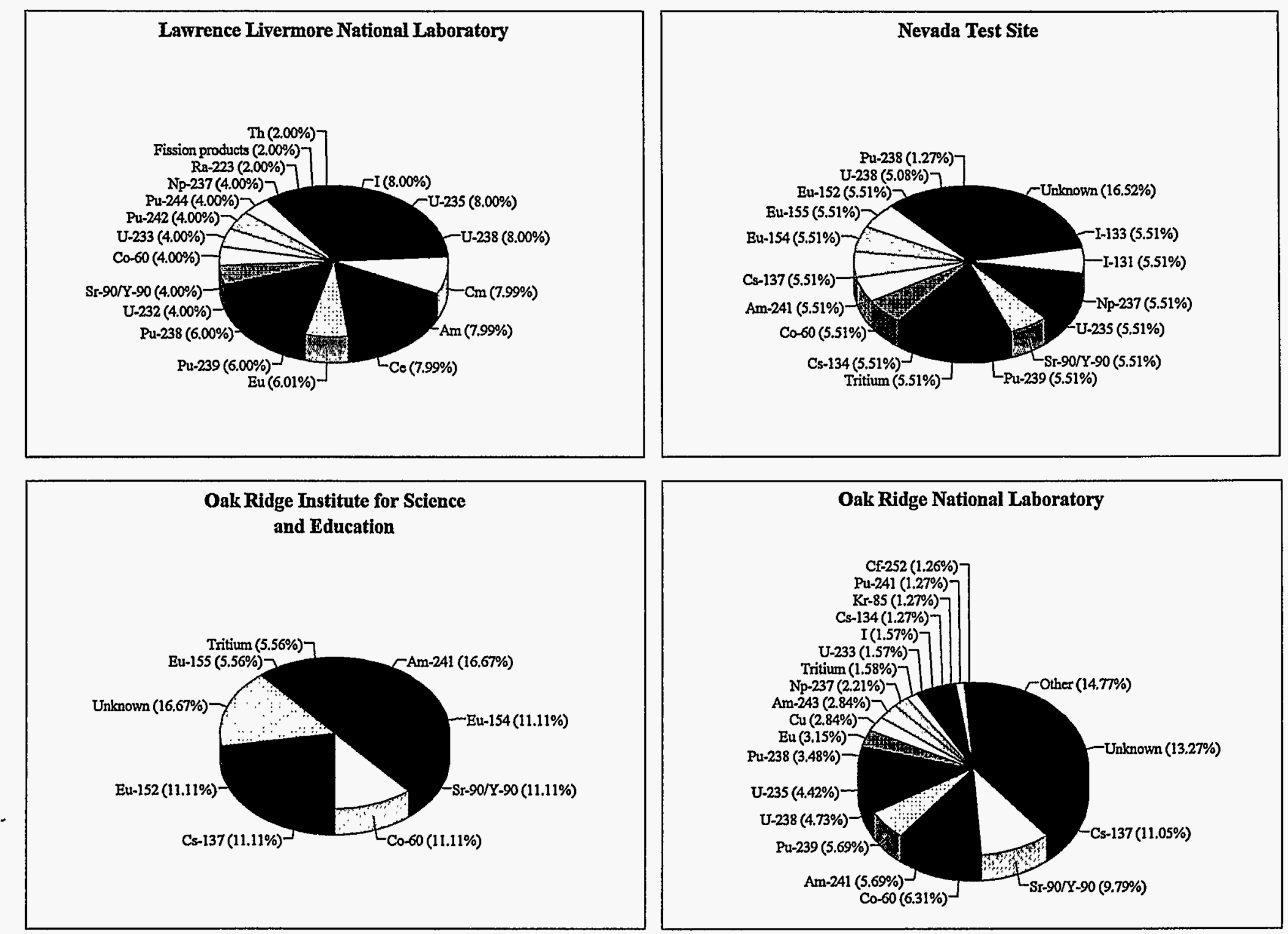

Fig. 2.3. (continued). 

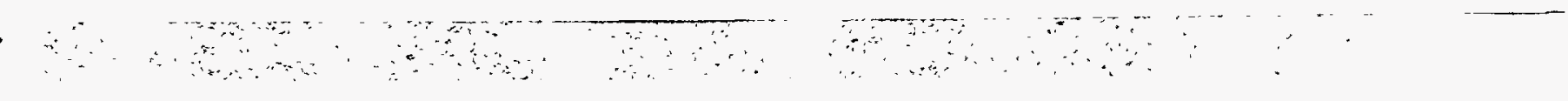

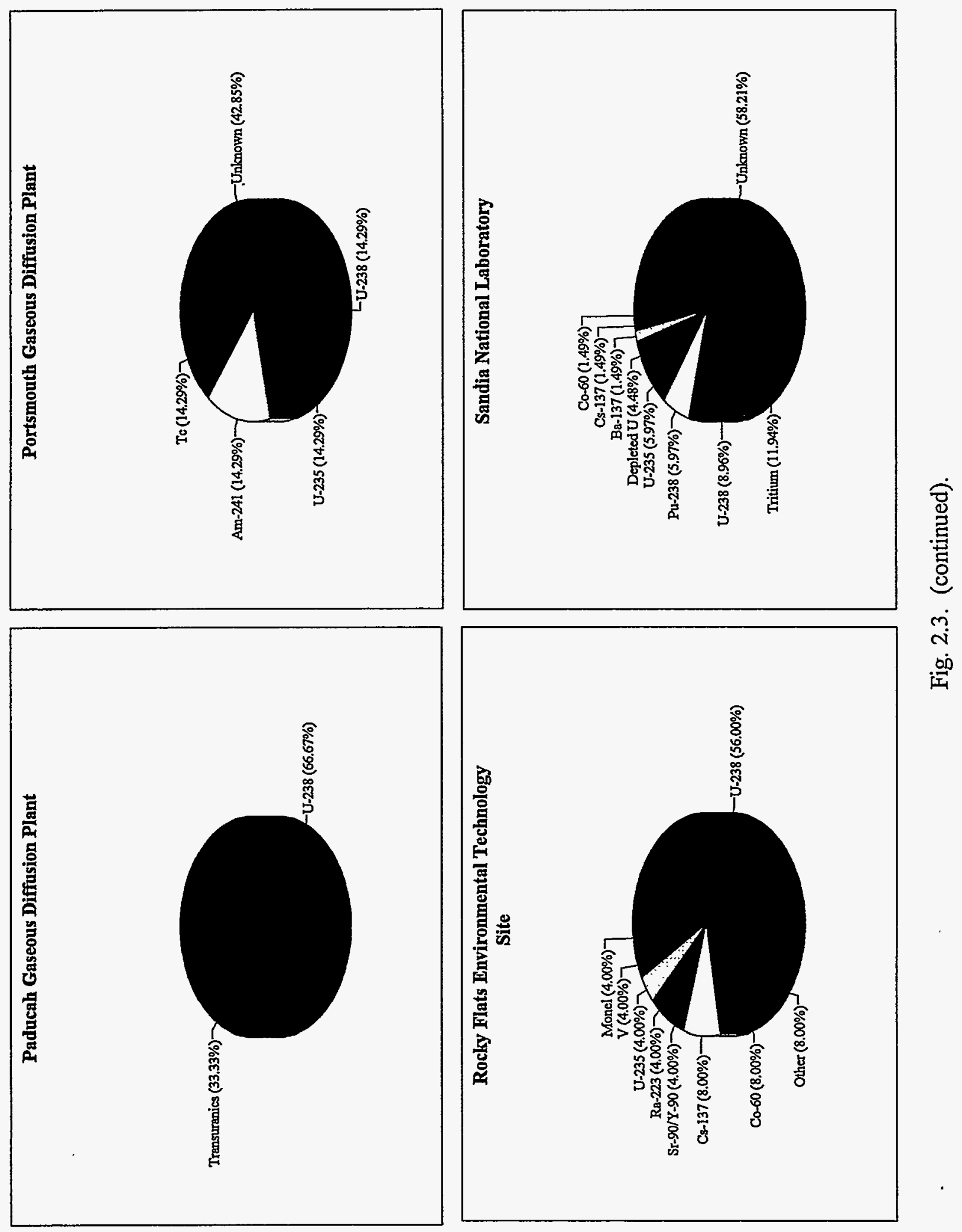

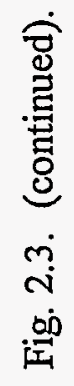




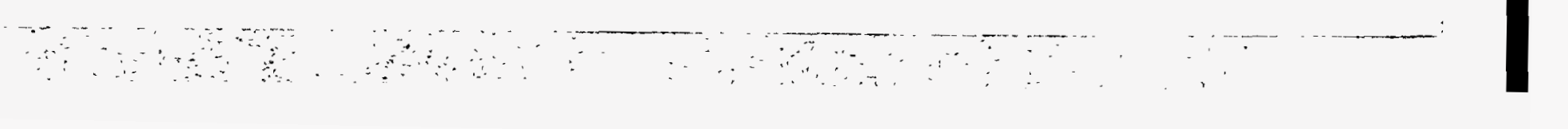


$2-28$

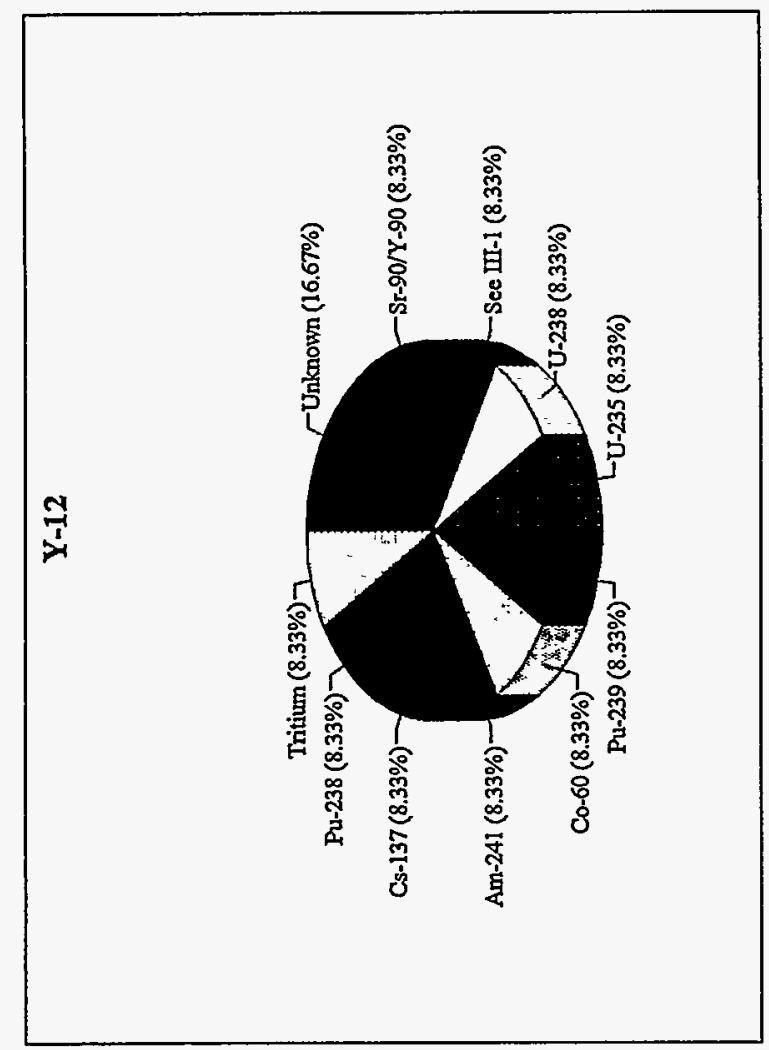

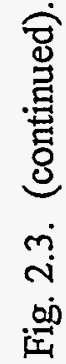

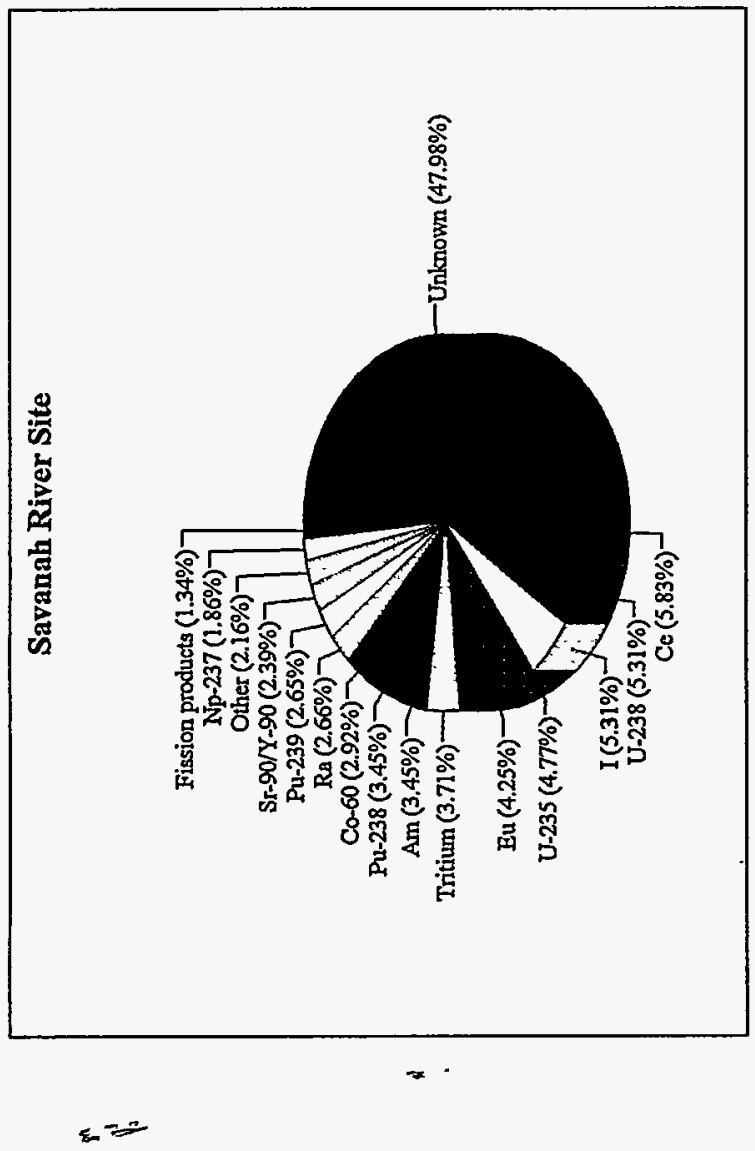


Table 2.6. Summary of technology assessment based on site queries

\begin{tabular}{|c|c|c|c|}
\hline Site & Contaminated area & Technologies under consideration & $\begin{array}{l}\text { Technology needs as identified by } \\
\text { the site }\end{array}$ \\
\hline ANLE & $\begin{array}{l}\text { Containment structures, } \\
\text { rod storage area }\end{array}$ & $\begin{array}{l}\text { Mechanical demolition and abrading, } \\
\text { scabbling, abrasive cleaning, pneumatic } \\
\text { demolition equipment }\end{array}$ & Unknown \\
\hline BCL & Undefined & $\begin{array}{l}\text { Vacuum blasting and scabbling, } \\
\text { jackhammers for deep cracks }\end{array}$ & None \\
\hline $\mathrm{BNL}$ & $\begin{array}{l}\text { Buildings, storage tanks, } \\
\text { reactor, canals, concrete } \\
\text { surfaces surrounding } \\
\text { duct work }\end{array}$ & Undefined & $\begin{array}{l}\text { Any cost-effective methods to } \\
\text { manage long-term risks and to } \\
\text { decontaminate prior to disposal }\end{array}$ \\
\hline ETEC & $\begin{array}{l}\text { Buildings, fuel storage } \\
\text { vaults }\end{array}$ & $\begin{array}{l}\text { Mechanical scabbling, hydraulic hammers } \\
\text { and jackhammers }\end{array}$ & Unknown \\
\hline FEMP & Buildings, silos & $\begin{array}{l}\text { Performance criteria provided to } \\
\text { subcontractor who then selects an } \\
\text { appropriate technology }\end{array}$ & Unknown \\
\hline GJPO & Concrete floors & Needle scabbling & None \\
\hline HANF & $\begin{array}{l}\text { Buildings (reactor and } \\
\text { support), laboratories, } \\
\text { canyon facilities, } \\
\text { underground storage } \\
\text { tanks }\end{array}$ & $\begin{array}{l}\text { Dry-ice blasting, arc saw, fixatives, water } \\
\text { cannon, concrete spalling, high-pressure } \\
\text { hot water jet, laser ablation, chemical } \\
\text { methods, needle guns, shot blasting }\end{array}$ & $\begin{array}{l}\text { None; technical approach has } \\
\text { been developed }\end{array}$ \\
\hline INEL & $\begin{array}{l}\text { Reactors and associated } \\
\text { structures (canals), hot } \\
\text { cell, chemical } \\
\text { processing plants }\end{array}$ & $\begin{array}{l}\text { Numerous technologies (see INEL } \\
\text { technology logic diagram, INEL 1994) }\end{array}$ & $\begin{array}{l}\text { Further research, development, } \\
\text { testing, and evaluation needed for } \\
\text { numerous technologies }\end{array}$ \\
\hline $\mathrm{KCP}$ & $\begin{array}{l}\text { Manufacturing } \\
\text { buildings, no rad } \\
\text { contamination }\end{array}$ & NA & NA \\
\hline $\begin{array}{l}\text { ORR } \\
\mathrm{K}-25\end{array}$ & $\begin{array}{l}82 \text { facilities slated for } \\
\text { D\&D }\end{array}$ & $\begin{array}{l}\text { Numerous technologies (see K-25 } \\
\text { technology logic diagram, } \\
\text { Oak Ridge K-25 Site } 1993\end{array}$ & $\begin{array}{l}\text { More efficient concrete surface } \\
\text { layer removal, reduction of } \\
\text { secondary wastes, innovative } \\
\text { systems for floor and wall } \\
\text { decontamination, reduction of } \\
\text { rubble waste }\end{array}$ \\
\hline LANL & $\begin{array}{l}\text { Floors and walls, one } \\
\text { reactor }\end{array}$ & $\begin{array}{l}\text { Mechanical scabbling, solvents, } \\
\text { microwave, laser technologies }\end{array}$ & Unknown \\
\hline LBL & $\begin{array}{l}\text { Concrete blocks used for } \\
\text { shielding }\end{array}$ & $\begin{array}{l}\text { Recycle and reuse; concrete shipped to } \\
\text { Oak Ridge will be pulverized and reused as } \\
\text { aggregate in new concrete for waste burial } \\
\text { boxes. }\end{array}$ & None \\
\hline LLNL & $\begin{array}{l}\text { No concrete D\&D } \\
\text { planned }\end{array}$ & NA & NA \\
\hline MND & Buildings & $\begin{array}{l}\text { Chemical extraction, blasting, and various } \\
\text { mechanical methods }\end{array}$ & Unknown \\
\hline
\end{tabular}




\section{2-30}

Table 2.6. (continued)

\begin{tabular}{|c|c|c|c|}
\hline Site & Contaminated area & Technologies under consideration & $\begin{array}{l}\text { Technology needs as identified by } \\
\text { the site }\end{array}$ \\
\hline NTS & Buildings & $\begin{array}{l}\text { None to date; previous concrete D\&D used } \\
\text { chipping and scabbling }\end{array}$ & Unknown \\
\hline $\begin{array}{l}\text { ORR } \\
\text { ORNL }\end{array}$ & $\begin{array}{l}\text { Reactors, buildings, } \\
\text { storage tanks }\end{array}$ & $\begin{array}{l}\text { Numerous technologies (see ORNL } \\
\text { technology logic diagram, ORNL 1993) }\end{array}$ & $\begin{array}{l}\text { More efficient concrete surface } \\
\text { layer removal, reduction of } \\
\text { secondary wastes, innovative } \\
\text { systems for floor and wall } \\
\text { decontamination, remote } \\
\text { decontamination, and } \\
\text { decontamination of rubble }\end{array}$ \\
\hline PANT & $\begin{array}{l}\text { No concrete } D \& D \text { to } \\
\text { date nor planned }\end{array}$ & $\mathrm{NA}$ & NA \\
\hline PGDP & Buildings & $\begin{array}{l}\text { Chemical treatments, ultra-high-pressure } \\
\text { water jetting, blasting, scarifying, and } \\
\text { vacuuming }\end{array}$ & Unknown \\
\hline PINP & $\begin{array}{l}\text { No concrete } D \& D \text { to } \\
\text { date nor planned }\end{array}$ & NA & NA \\
\hline PNL & Included with Hanford & Included with Hanford & Included with Hanford \\
\hline PORTS & Buildings & None; $\mathrm{D} \& \mathrm{D}$ is in planning stage & Unknown \\
\hline PPPL & $\begin{array}{l}\text { Tokamak fusion test } \\
\text { reactor scheduled for } \\
\text { D\&D in } 9 / 95\end{array}$ & Very little D\&D planned & None \\
\hline RFETS & Buildings & $\begin{array}{l}\text { Scabbling, strippable coatings, } \mathrm{CO}_{2} \\
\text { blasting }\end{array}$ & Unknown \\
\hline RMIT & Buildings & $\begin{array}{l}\text { Scabbling and vacuuming, chemical, } \\
\text { mechanical, and electrical technologies }\end{array}$ & $\begin{array}{l}\text { Technologies with cost and } \\
\text { schedule reductions }\end{array}$ \\
\hline SNLI & D\&D delayed to FY96 & Unknown & Unknown \\
\hline SRS & $\begin{array}{l}\text { Reactors, buildings, } \\
\text { canyons, waste tanks }\end{array}$ & Conventional technologies & Unknown \\
\hline WSS & Buildings & High-pressure water, vacuums & None \\
\hline WVDP & Chemical process cell & $\begin{array}{l}\text { D\&D completed used high-pressure } \\
\text { detergent washing and vacuuming }\end{array}$ & Unknown \\
\hline $\begin{array}{l}\text { ORR } \\
\text { Y-12 }\end{array}$ & Buildings & $\begin{array}{l}\text { High-pressure water jet, pelletized carbon } \\
\text { dioxide }\end{array}$ & $\begin{array}{l}\text { More efficient concrete surface } \\
\text { layer removal, reduction of } \\
\text { secondary wastes, innovative } \\
\text { systems for floor and wall } \\
\text { decontamination }\end{array}$ \\
\hline
\end{tabular}

Note: This table was generated from information provided in the site queries. More detailed information is presented in Appendix A.

$\mathrm{NA}=$ not applicable 
Table 2.7. Past experience in concrete decontamination

\begin{tabular}{|c|c|c|c|c|}
\hline Date & Technology & Site & Result & Comments \\
\hline $\begin{array}{l}\text { June } 1972 \\
\text { to July } 1974\end{array}$ & Explosives & $\begin{array}{l}\text { Elk River Reactor: } \\
\text { biological shicld, fuel } \\
\text { element storage well }\end{array}$ & $\begin{array}{l}\text { Good; removal of } 1550 \mathrm{yd}^{3} \text { of concrete } \\
\text { utilizing } 1200 \mathrm{lb} \text { of explosives. }\end{array}$ & $\begin{array}{l}\text { Blast mats and water fog systems were used to suppress rock throw } \\
\text { and dust production during blasting activities. High levels of airborne } \\
\text { contamination were experienced following blasting activities, but were } \\
\text { minimized by air filtration and area cover systems. (Anderson 1980) }\end{array}$ \\
\hline 1976 & Explosives & $\begin{array}{l}\text { Princeton Industrial } \\
\text { Reactor Laboratory: } \\
\text { pool walls, beam tube } \\
\text { liners, isotope garden }\end{array}$ & $\begin{array}{l}\text { Good; efficient removal of wall surface to } \\
\text { a depth of } 3 \text { to } 4 \text { in. }\end{array}$ & $\begin{array}{l}\text { Blast mats and water fog was used to contain }{ }^{137} \mathrm{Cs} \text { and }{ }^{60} \mathrm{Co} \\
\text { contaminants. (Anderson 1980) }\end{array}$ \\
\hline Pre-1979 & $\begin{array}{l}\text { Scabbler tool, } \\
7 \text {-piston floor } \\
\text { model }\end{array}$ & $\begin{array}{l}\text { Sodium reactor } \\
\text { experiment, } \\
\text { Santa Suzanna, Calif. }\end{array}$ & $\begin{array}{l}\text { Good; up to } 3 / 8 \mathrm{in.} \text { of concrete can be } \\
\text { removed. When removing } 1 / 8 \mathrm{in.} \mathrm{to} \\
1 / 4 \mathrm{in} \text {., removal rates of approximately } \\
0.5 \mathrm{ft}^{2} / \text { min are achieved. }\end{array}$ & $\begin{array}{l}\text { No information in literature concerning depth of removal or } \\
\text { contamination levels. (Brengle 1979) }\end{array}$ \\
\hline $\begin{array}{l}1993 \text { to } \\
1995\end{array}$ & $\begin{array}{l}\text { Scabbling, } \\
\text { tractor- mounted } \\
\text { hammer, } \\
\text { jackhammer }\end{array}$ & ETEC: Building T020 & $\begin{array}{l}\text { Good; } \$ 20 \mathrm{M} \text { decontamination project, } \\
90 \% \text { of which was accomplished using } \\
\text { conventional technologies. }\end{array}$ & $\begin{array}{l}\text { Mechanical scabbling was/is used to remove surface contamination. } \\
\text { Backhoe-mounted pneumatic hammer and manual jackhammers } \\
\text { were/are used to remove grossly contaminated concrete. Contami- } \\
\text { nated penetrations are removed by core drilling. (Phil Horton, ETEC, } \\
\text { personal communication with D.S. Foster, ORNL, 1995) }\end{array}$ \\
\hline$\sim 1994$ & Needle scabbling & GJPO & $\begin{array}{l}\text { Good; decontaminated approximately } 330 \mathrm{ft}^{2} \\
\text { of concrete floor, removing less than one } \\
5 \text {-gal bucket of material. }\end{array}$ & $\begin{array}{l}\text { Contaminants removed included }{ }^{226} \mathrm{Ra} \text { and decay products. Contami- } \\
\text { nation was removed to an off-site disposal area. (Steven G. Corle, } \\
\text { Rust Geotech, personal communication with D.S. Foster, ORNL, } \\
\text { 1995) }\end{array}$ \\
\hline $\begin{array}{l}1994 \text { to } \\
2004\end{array}$ & $\begin{array}{l}\text { Mechanical } \\
\text { scabbling }\end{array}$ & LANL & $\begin{array}{l}\text { Unknown; mechanical scabbling used to } \\
\text { remove low-level Pu and U contamination } \\
\text { from concrete walls and floors. }\end{array}$ & $\begin{array}{l}\text { Volume is estimated at } 6000 \mathrm{yd}^{3} \text {. Decontamination techniques to be } \\
\text { tried in the future may include solvent, microwave, and/or laser tech- } \\
\text { nologies. Decontamination costs are expected to cost from } \$ 500,000 \\
\text { to } \$ 1.5 \text { million per year. (Miguel Salazar, LANL, personal communi- } \\
\text { cation with D.S. Foster, ORNL, 1995) }\end{array}$ \\
\hline 1994 & $\begin{array}{l}\text { "Squirrel" and } \\
\text { "needle" gun }\end{array}$ & ORR: Building 1401 & $\begin{array}{l}\text { Good; these devices clean at a rate up to } \\
12 \mathrm{ft}^{2} / \mathrm{h} \text {. Cleanup of } 24 \mathrm{ft}^{2} \text { results in } \\
<100 \mathrm{~g} \text { of waste, because the contami- } \\
\text { nation is contained in the upper } 0.5 \mathrm{~mm} \\
\text { of concrete. }\end{array}$ & $\begin{array}{l}\text { Health physics costs were the largest cost component. The use of sol- } \\
\text { vents and acids have not been allowed due to mixed waste generation } \\
\text { concerns. (Ronnie K. McMahan, ORR, personal communication with } \\
\text { D.S. Foster, ORNL, 1995) }\end{array}$ \\
\hline 1994 & $\begin{array}{l}\text { Mechanical } \\
\text { Scabbling }\end{array}$ & RFETS & $\begin{array}{l}\text { Good; D\&D has been successfully completed } \\
\text { using a dustless decontamination system by } \\
\text { Pentek. }\end{array}$ & $\begin{array}{l}\text { Scabbling is being considered for future D\&D projects at RFETS. } \\
\text { Also under consideration are strippable coatings for the decontami- } \\
\text { nation of glove boxes. The rate of concrete decontamination with } \\
\text { the Pentek system was about } 30 \mathrm{ft}^{2} / \mathrm{h} \text {. (Michael Simmons, RFETS, } \\
\text { personal communication with D.S. Foster, ORNL, 1995) }\end{array}$ \\
\hline
\end{tabular}


Table 2.7. (continued)

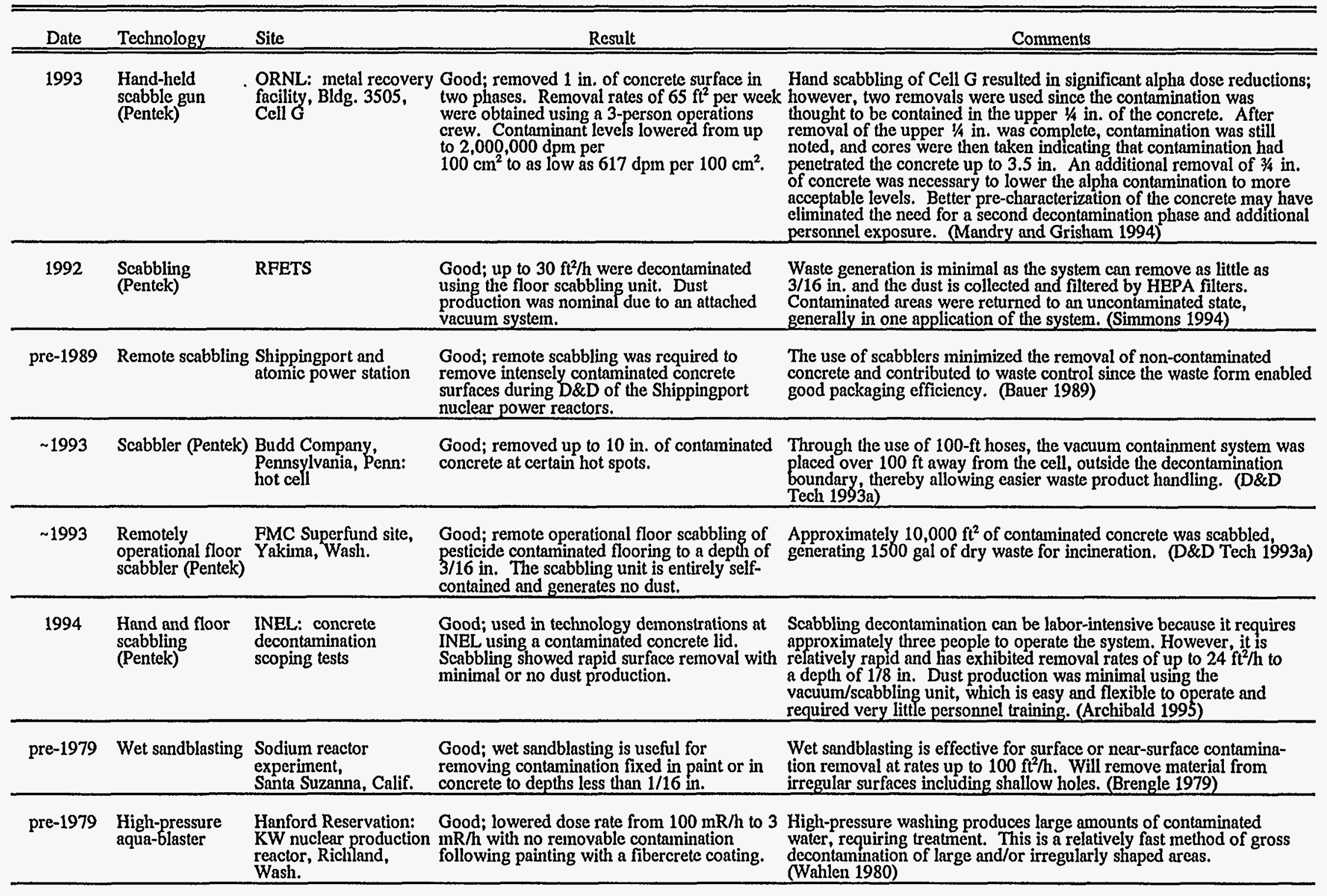


Table 2.7. (continued)

\begin{tabular}{|c|c|c|c|c|}
\hline Date & Technology & Site & Result & Comments \\
\hline $1979-1980$ & $\begin{array}{l}\text { Hydroblasting, } \\
\text { hand scrubbing, } \\
\text { and wet-vacuum } \\
\text { removal }\end{array}$ & $\begin{array}{l}\text { Three Mile Island: } \\
\text { Unit II power facility, } \\
\text { elevator pit }\end{array}$ & $\begin{array}{l}\text { Moderate; elevator shaft was not seal-coated, } \\
\text { which allowed the contaminants to penetrate } \\
\text { the walls and floors up to } 2 \mathrm{~cm} \text { in depth. }\end{array}$ & $\begin{array}{l}\text { Initial dose levels of } 7 \mathrm{R} / \mathrm{h} \text { were reduced to } 1 \mathrm{R} / \mathrm{h} \text { following } \\
\text { hydroblasting and additionally to } 400 \text { to } 700 \mathrm{mR} / \mathrm{h} \text { by scrubbing. } \\
\text { Further dose reductions will require concrete removal and chemical } \\
\text { etching due to the penetration of the contamination into the uncoated } \\
\text { concrete walls and floor of the elevator pit. (Irving 1980) }\end{array}$ \\
\hline $1979-1980$ & $\begin{array}{l}\text { Remote } \\
\text { hydroblasting }\end{array}$ & $\begin{array}{l}\text { Three Mile Island: } \\
\text { Unit II power facility, } \\
\text { seal injection valve } \\
\text { room }\end{array}$ & $\begin{array}{l}\text { Poor to good; concrete areas with surface } \\
\text { coatings were reduced from } 50 \text { to } 70 \mathrm{R} / \mathrm{h} \\
\text { to } 2 \mathrm{R} / \mathrm{h} \text { due to the coating effectiveness. } \\
\text { Uncoated areas were reduced from approxi- } \\
\text { mately } 550 \mathrm{R} / \mathrm{h} \text { to } 200 \mathrm{R} / \mathrm{h} \text {. Further reduc- } \\
\text { tion could not be obtained due to penetration } \\
\text { of the concrete by contamination. }\end{array}$ & $\begin{array}{l}\text { Initial contamination on the floor was } 550 \mathrm{R} / \mathrm{h} \text { gamma and } 5900 \mathrm{rad} \\
\text { beta. Concrete coatings were shown to have prevented significant } \\
\text { amounts of penetration of the concrete by contaminants. Removal } \\
\text { activities will be required to complete the cleanup of the seal injection } \\
\text { valve room. (Irving 1980) }\end{array}$ \\
\hline 1992 & $\begin{array}{l}\text { Sponge-jet } \\
\text { (Sponge-Jet, } \\
\text { Inc.) }\end{array}$ & $\begin{array}{l}\text { Aerojet Ordinance } \\
\text { Tennessee Depleted } \\
\text { Uranium Facility }\end{array}$ & $\begin{array}{l}\text { Good; sponge-jet technology utilizes a foam } \\
\text { abrasive media to replace sandblasting, high- } \\
\text { pressure water jetting, power tool cleaning, } \\
\text { and hand scrubbing. }\end{array}$ & $\begin{array}{l}\text { The sponge-jet system utilizes a foam abrasive technology to mini- } \\
\text { mize impact and ricochet distances of traditional or high-pressure } \\
\text { abrasive systems. Medium can be reused or recycled with a break- } \\
\text { down rate of } 2 \text { to } 5 \% \text {. (D\&D Tech 1993b) }\end{array}$ \\
\hline $1968-1972$ & Pressure washing & $\begin{array}{l}\text { Mound Facility: } \\
\text { special metallurgical } \\
\text { building }\end{array}$ & $\begin{array}{l}\text { Moderate to good; initial contamination was } \\
\text { reduced from an average of } 2,000,000 \mathrm{cpm} \\
\text { to } 50,000 \mathrm{cpm} \text {. }\end{array}$ & $\begin{array}{l}\text { Pressure washing is generally effective for gross contamination } \\
\text { removal; however, the area will require additional hand scrubbing and } \\
\text { concrete removal to obtain a conditional or unconditional release of } \\
\text { the facility. (Combs et al. 1980) }\end{array}$ \\
\hline 1978 & $\begin{array}{l}\text { Pneumatic } \\
\text { scarifiers (hand- } \\
\text { held and floor } \\
\text { models) }\end{array}$ & $\begin{array}{l}\text { LANL: Plutonium } \\
\text { Operations, DP-West }\end{array}$ & $\begin{array}{l}\text { Good; removed concrete flooring to a depth } \\
\text { of up to } 1 \text { in. No contamination has been } \\
\text { noted after scarifying is complete. }\end{array}$ & $\begin{array}{l}\text { The scarifying method produces approximately } 4 \text { gal of water for each } \\
1 \mathrm{~m}^{2} \text { of decontamination. The system utilizes up to } 3 \text { people at a time } \\
\text { to minimize fatigue. The floor model can decontaminate up to } 1 \mathrm{~m}^{2} / \mathrm{h} \text {. } \\
\text { (Cox and Garde 1980) }\end{array}$ \\
\hline 1984 & Flame scarfing & $\begin{array}{l}\text { Grundremminger } \\
\text { KRB-A }\end{array}$ & $\begin{array}{l}\text { Unknown; flame scarfing was proven } \\
\text { effective at the decommissioned nuclear } \\
\text { power plant, Grundremmingen KRB-A. }\end{array}$ & $\begin{array}{l}\text { Testing was conducted by Salzgitler AG/NOELL as part of the } \\
\text { community research program "Decommissioning of Nuclear Power } \\
\text { Plants". (Ebeling et al. 1984) }\end{array}$ \\
\hline $1959-1961$ & $\begin{array}{l}\text { Hand cleaning, } \\
\text { floor grinding, } \\
\text { jackhammer } \\
\text { removal, and } \\
\text { pressure washing }\end{array}$ & $\begin{array}{l}\text { ORNL: Bldg. } 3019 \\
\text { contaminated with Pu } \\
\text { following a chemical } \\
\text { explosion }\end{array}$ & $\begin{array}{l}\text { Moderate; lowered contamination levels, but } \\
\text { resulted in the generation of abundant mixed } \\
\text { hazardous wastes due to use of acids for } \\
\text { contamination removal. }\end{array}$ & $\begin{array}{l}44,000 \mathrm{ft}^{2} \text { of concrete contaminated with Pu ranging from } 50 \text { to } \\
100,000,000 \text { dis } / \mathrm{min} / 100 \mathrm{~cm}^{2} \text {. Concrete coatings would have avoided } \\
\text { significant amounts of removal activities through the prevention of } \\
\text { concrete penetration by the radioactive materials. (Parrott 1980) }\end{array}$ \\
\hline $1979-1980$ & $\begin{array}{l}\text { Scrubbing and } \\
\text { wet-vacuum } \\
\text { removal }\end{array}$ & $\begin{array}{l}\text { Three Mile Island: } \\
\text { Unit II power facility, } \\
\text { diesel generator } \\
\text { building bays }\end{array}$ & $\begin{array}{l}\text { Good; prior seal coating of the concrete } \\
\text { allowed efficient removal of the contaminants }\end{array}$ & $\begin{array}{l}\text { Initial contamination of } 3,000,000 \mathrm{dpm} \text { was lowered to }<1000 \mathrm{dpm} \\
\text { in two scrubbing and wet-vacuum recovery passes. Good seal coat- } \\
\text { ings on the concrete surfaces are credited for preventing significant } \\
\text { penetration of the concrete by the contaminants. (Irving 1980) }\end{array}$ \\
\hline
\end{tabular}


Table 2.7. (continued)

\begin{tabular}{|c|c|c|c|c|}
\hline Date & Technology & Site & Result & Comments \\
\hline $1979-1980$ & $\begin{array}{l}\text { Floor buffers and } \\
\text { wet-vacuum } \\
\text { removal }\end{array}$ & $\begin{array}{l}\text { Three Mile Island: } \\
\text { Unit II power facility, } \\
\text { general floor areas }\end{array}$ & $\begin{array}{l}\text { Good; seal-coated floors allowed for efficient } \\
\text { removal of radioactive contamination. }\end{array}$ & $\begin{array}{l}\text { Initial contamination of } 15 \mathrm{R} / \mathrm{h} \text { was lowered to }<5000 \mathrm{dpm} \text { after } \\
\text { approximately six weeks of decontamination efforts. Seal coatings are } \\
\text { credited with preventing penetration of the concrete by the contami- } \\
\text { nants. (Irving 1980) }\end{array}$ \\
\hline $1979-1980$ & $\begin{array}{l}\text { Hand scrubbing } \\
\text { and wet vacuum }\end{array}$ & $\begin{array}{l}\text { Three Mile Island: } \\
\text { Unit II power facility, } \\
\text { containment annulus }\end{array}$ & $\begin{array}{l}\text { Poor to moderate; gamma exposure was } \\
\text { lowered from } 1 \text { to } 3 \mathrm{R} / \mathrm{h} \text { to } 200 \text { to } \\
300 \mathrm{mR} / \mathrm{h} \text {; however, beta contamination was } \\
\text { little reduced, indicating significant } \\
\text { penetration of the uncoated concrete. }\end{array}$ & $\begin{array}{l}\text { Initial beta contamination levels of } 2 \text { to } 10 \text { rad were little affected by } \\
\text { the clean-up efforts, indicating that the contamination had penetrated } \\
\text { the concrete surfaces. Concrete removal will be required to complete } \\
\text { the decontamination of the containment annulus. (Irving 1980) }\end{array}$ \\
\hline $1970 \mathrm{~s}$ & $\begin{array}{l}\text { Pavement } \\
\text { breaker } \\
\text { (jackhammer) }\end{array}$ & Mound Facility & $\begin{array}{l}\text { Good; cleanup of } 1,500,000 \mathrm{cpm} \text { to } \\
\text { background levels. }\end{array}$ & $\begin{array}{l}\text { Dust containment and air filtration measures are required during } \\
\text { operation of pavement breaker equipment. (Combs et al. 1980) }\end{array}$ \\
\hline pre-1975 & $\begin{array}{l}\text { Pneumatic } \\
\text { hammer } \\
\text { (jackhammer) }\end{array}$ & SRS & $\begin{array}{l}\text { Unknown; jackhammering was used to } \\
\text { remove concrete in a highly contaminated } \\
\text { obsolete } 239 \text { Pu facility. While it is evident that } \\
\text { jackhammering was successful, it is unclear } \\
\text { whether other technologies may have been } \\
\text { more appropriate. }\end{array}$ & $\begin{array}{l}\text { Significant dust was generated during the jackhammering removal } \\
\text { activities. Air-supplied respiratory protection and protective suits } \\
\text { were required at an times for all activities. Therefore, dust generation } \\
\text { may not have had much of an adverse affect on the overall removal } \\
\text { activities. (Caldwell and Harper 1975) }\end{array}$ \\
\hline$\sim 1975$ & Vacu-Blast & Mound Facility & $\begin{array}{l}\text { Good; used for spot decontamination of } \mathrm{Pu} \\
\text { contaminants. }\end{array}$ & $\begin{array}{l}\text { Uses abrasives and internal vacuum mechanism to remove concrete } \\
\text { contamination. Can reclaim and recycle the abrasives for reuse. } \\
\text { Generally used for small area decontamination. Can significantly } \\
\text { lower contamination levels in concrete with shallow penetration of the } \\
\text { contaminants. (Combs et al. 1980) }\end{array}$ \\
\hline 1995 & $\begin{array}{l}\text { Vacuum blasting } \\
\text { and jackhammers }\end{array}$ & $\begin{array}{l}\text { Batelle Columbus } \\
\text { Laboratory }\end{array}$ & $\begin{array}{l}\text { Good; approximately } 200,000 \mathrm{ft}^{2} \text { of concrete } \\
\text { has been decontaminated. Contamination } \\
\text { depth varies from } 1 / 16 \text { in. to } 5 \text { or } 6 \text { in. }\end{array}$ & $\begin{array}{l}\text { Contamination at this site included } U, T h \text {, and some mixed fission } \\
\text { products. Vacuum blasting has been used for shallow ( }<1 / 16 \text { in.) } \\
\text { contamination removal, while jackhammering has been used for deep } \\
\text { cracks in concrete. Vacuum blasting removed about } 95 \% \text { of the } \\
\text { contanination. (Ron Carlson, BCL, personal communication with } \\
\text { D.S. Foster, ORNL, 1995) }\end{array}$ \\
\hline pre-1995 & Vacuum blasting & LBL & $\begin{array}{l}\text { Poor; attempted to decontaminate a } 10 \mathrm{ft} \times \\
10 \mathrm{ft} \times 18 \text {-m. concrete pad contaminated } \\
\text { with transformer oil containing PCBs. }\end{array}$ & $\begin{array}{l}\text { Vacuum blasting pushed the contaminated oil deeper into the con- } \\
\text { crete. Detergent (Moxie Clean) was more successful at removing the } \\
\text { contamination. (Mike Schoonover, LBL, personal communication } \\
\text { with D.S. Foster, ORNL, 1995) }\end{array}$ \\
\hline
\end{tabular}


Table 2.7. (continued)

\begin{tabular}{|c|c|c|c|c|}
\hline Date & Technology & Site & Result & Comments \\
\hline 1994 & $\begin{array}{l}\text { Solvent } \\
\text { extraction }\end{array}$ & Mound Facility & $\begin{array}{l}\text { Good; contaminants may include } \mathrm{Pu} \text {, } \\
\text { tritium, and Th. }\end{array}$ & $\begin{array}{l}\text { Environmental and Extraction Technologies (EET) has conducted two } \\
\text { pilot tests on tile-covered floors that have yielded good decontamina- } \\
\text { tion results. If solvents don't work, the best approach has been use of } \\
\text { an enclosed recycling abrasive blaster. Mound has experienced prob- } \\
\text { lems with the ability of Health Physics to free-release the remaining } \\
\text { concrete after decontamination. (W.P. Davis, MND, Personal } \\
\text { communication with D.S. Foster, ORNL, 1995) }\end{array}$ \\
\hline 1994 & $\begin{array}{l}\text { Carbon dioxide } \\
\text { blasting }\end{array}$ & ORR: Building 1401 & $\begin{array}{l}\text { Poor; extremely expensive and worker } \\
\text { unfriendly. }\end{array}$ & $\begin{array}{l}\text { The use of acids and solvents at K-25 have not been allowed due to } \\
\text { mixed-waste generation concerns. (Ronnie K. McMahan, ORR, } \\
\text { personal communication with D.S. Foster, ORNL, 1995) }\end{array}$ \\
\hline$\sim 1993$ & $\begin{array}{l}\text { Chemical } \\
\text { extraction } \\
\text { (EET, Inc., } \\
\text { TechX'ract) }\end{array}$ & $\begin{array}{l}\text { Portsmouth: } \\
\text { Building 705A }\end{array}$ & $\begin{array}{l}\text { Moderate to poor; product was applied to an } \\
\text { epoxy-coated concrete slab contaminated with } \\
\text { beta and gamma. Contaminant removal was } \\
\text { not as effective as hoped because the } \\
\text { radionuclides were either bonded to or under } \\
\text { the epoxy coating. }\end{array}$ & $\begin{array}{l}\text { The TechXtract was a technology demonstration project and involved } \\
\text { three applications of the product to a concrete slab contaminated with } \\
\text { isotopes of U and potentially contaminated with Tc and TRU. (Bill } \\
\text { Schloesslin, PORTS, personal communication with D.S. Foster, } \\
\text { ORNL, 1995) }\end{array}$ \\
\hline$\sim 1994$ & $\begin{array}{l}\text { Hot gas decon- } \\
\text { tamination }\end{array}$ & $\begin{array}{l}\text { Rocky Mountain } \\
\text { Arsenal }\end{array}$ & $\begin{array}{l}\text { Unknown; hot gas decontamination was used } \\
\text { to decontaminate chemical agent mustard. } \\
\text { Total treatment time was } 5 \text { weeks with a total } \\
\text { cost of } \$ 5.2 \mathrm{M} \text {. }\end{array}$ & $\begin{array}{l}\text { Hot gas }\left(700 \text { to } 800^{\circ} \mathrm{F}\right) \text { was introduced into the building; } 117 \text { thermo- } \\
\text { couples were installed to monitor temperature in the walls and floor. } \\
\text { When all thermocouples had heated to } 350^{\circ} \mathrm{F} \text { temperature was main- } \\
\text { tained for } 24 \mathrm{~h} \text { and then allowed to cool. Contaminant was vented } \\
\text { through an exhaust duct and burned at } 2000^{\circ} \mathrm{F} \text {. Results of the test } \\
\text { should be available in March } 1995 \text {. Wayne Sisk, Rocky Mountain } \\
\text { Arsenal, personal communication with D.S. Poster, ORNL, 1995) }\end{array}$ \\
\hline pre-1994 & $\begin{array}{l}\text { Carbon dioxide } \\
\text { blaster }\end{array}$ & RFETS & $\begin{array}{l}\text { Poor; carbon dioxide blaster was physically } \\
\text { tiring for the workers, expensive, and } \\
\text { worked better on metal than on concrete. } \\
\text { (Michael Simmons, RPETS, personal } \\
\text { communication with D.S. Poster, ORNL, } \\
\text { 1995) }\end{array}$ & \\
\hline $\begin{array}{l}1985 \text { to } \\
1987\end{array}$ & $\begin{array}{l}\text { Remotely } \\
\text { operated cranes } \\
\text { and electro- } \\
\text { mechanical } \\
\text { vacuums and } \\
\text { cutting tools }\end{array}$ & $\begin{array}{l}\text { WVDP: chemical } \\
\text { process cell (CPC) }\end{array}$ & $\begin{array}{l}\text { Assumed to be good; CPC was decontami- } \\
\text { nated by remote removal of piping, and } \\
\text { vessels. Floors, walls, etc., were vacuumed, } \\
\text { and three } 22.5 \text {-ton concrete neutron absor- } \\
\text { bers were remotely cut and removed using } \\
\text { overhead cranes and an electromechanical } \\
\text { manipulator. }\end{array}$ & $\begin{array}{l}\text { Estimated curie content of the CPC that was removed was above } \\
210 \mathrm{Ci} \text { for } \mathrm{Cs} \text {, Sr, and Pu. Total volume of the primary decommis- } \\
\text { sioning waste was over } 850 \mathrm{~m}^{3} ; \text { an additional } 217 \mathrm{~m}^{3} \text { of secondary } \\
\text { waste was also generated. (Dan Burke, WVDP, personal communi- } \\
\text { cation with D.S. Foster, ORNL, 1995) }\end{array}$ \\
\hline$\sim 1988$ & Foam & SRS & $\begin{array}{l}\text { Good; foam (composition unknown) is used } \\
\text { in conjunction with nitric acid to provide a } \\
\text { low-impact, low-pressure decontamination } \\
\text { fluid. }\end{array}$ & $\begin{array}{l}\text { Although specific radiological levels are not listed, foam has been } \\
\text { used with excellent results to remove smearable contamination. The } \\
\text { system yielded significant waste reduction over conventional washing } \\
\text { system. (Peterson et al. 1991) }\end{array}$ \\
\hline
\end{tabular}


Table 2.7. (continued)

\begin{tabular}{|c|c|c|c|c|}
\hline Date & Technology & Site & Result & Comments \\
\hline 1993 & $\begin{array}{l}\text { Removable } \\
\text { surface coating } \\
\text { (Pentek 604 } \\
\text { paint) }\end{array}$ & $\begin{array}{l}\text { ORNL: Metal } \\
\text { Recovery Pacility, } \\
\text { Bldg. } 3505 \text {, } \\
\text { Cell G }\end{array}$ & $\begin{array}{l}\text { Poor; coating applied to a stainless steel floor } \\
\text { pan in an attempt to bond removable con- } \\
\text { tamination to the coating which contracts and } \\
\text { flakes upon drying allowing easy removal of } \\
\text { the coating. }\end{array}$ & $\begin{array}{l}\text { No significant reduction in activity levels were noted from pre- } \\
\text { application measurements to post-applications measurements. } \\
\text { (Mandry and Grisham 1994) }\end{array}$ \\
\hline 1994 & $\begin{array}{l}\text { Chemical } \\
\text { Extraction } \\
\text { (EET Tech- } \\
\text { Xtract) }\end{array}$ & $\begin{array}{l}\text { INEL: concrete } \\
\text { decontamination } \\
\text { scoping tests }\end{array}$ & $\begin{array}{l}\text { Good to moderate; in technology demon- } \\
\text { strations, chemical extractions showed that } \\
\text { with enough applications, the test concrete } \\
\text { could be cleaned from } 21,000 \text { dpm beta- } \\
\text { gamma to free-release levels. However, } \\
\text { numerous applications and removals of } \\
\text { chemicals subject personnel to increased } \\
\text { exposure and may increase total project } \\
\text { completion time over other technologies. }\end{array}$ & $\begin{array}{l}\text { EET's decontamination technique was easy to use and took } \\
\text { approximately } 15 \text { min per application to cover the } 24-\mathrm{ft}^{2} \text { area } \\
\text { of test concrete. Chemical dwell time varied from } 2 \text { to } 24 \mathrm{~h} \text { for the } \\
\text { three types of chemical extractants required for the job. The six } \\
\text { applications of chemicals required for this technology demonstration } \\
\text { generated approximately } 2 \text { gal of liquid waste, including rinse waters. } \\
\text { This represents a much lower generation of liquid waste compared to } \\
\text { detergents and water jet blasting. Use of the chemical extraction } \\
\text { agents will not destroy the concrete substrate that is being cleaned. } \\
\text { (Archibald 1995) }\end{array}$ \\
\hline 1994 & $\begin{array}{l}\text { Chemical } \\
\text { extraction }\end{array}$ & Portsmouth & $\begin{array}{l}\text { Good to poor; fixed alpha was reduced to } \\
\text { below release limits in three applications. } \\
\text { However, beta-gamma levels did not change } \\
\text { appreciably after } 6 \text { applications. }\end{array}$ & $\begin{array}{l}\text { Initial contamination levels treated were } 10,800 \mathrm{dpm} / 100 \mathrm{~cm}^{2} \text { alpha } \\
\text { and } 20,800 \text { and } 36,667 \mathrm{dpm} / 100 \mathrm{~cm}^{2} \text { for beta and gamma. A paint } \\
\text { coating on scattered portions of the sample surface appears to have } \\
\text { confounded the efficiency of the chemical extraction process. } \\
\text { (Davenport and Houk 1995) }\end{array}$ \\
\hline pre-1992 & $\begin{array}{l}\text { Chemical } \\
\text { removal of } \\
\text { painted coatings } \\
\text { on concrete }\end{array}$ & RFETS & $\begin{array}{l}\text { Good; methylene-chloride based strippers } \\
\text { proved superior to non-solvent based paint } \\
\text { removers. }\end{array}$ & $\begin{array}{l}\text { This option may be limited due to the long-term storage of the } \\
\text { stripped paint and due to lack of disposal options for the mixed } \\
\text { hazardous waste created by this process. (Simmons 1994) }\end{array}$ \\
\hline$\sim 1992$ & Shot blasting & $\begin{array}{l}\text { Elza Gate site } \\
\text { Oak Ridge, Tenn. }\end{array}$ & $\begin{array}{l}\text { Good to poor; removal of surface con- } \\
\text { tamination was completed; however, } \\
\text { contamination remained in cracks and } \\
\text { expansion joints. }\end{array}$ & $\begin{array}{l}\text { Original slab size was } 12,000 \mathrm{ft}^{2} \text {, which was contaminated by }{ }^{255} \mathrm{Ra} \text {, } \\
{ }^{232} \mathrm{Th} \text {, }{ }^{230} \mathrm{Th} \text {, and }{ }^{238} \mathrm{U} \text {. It is assumed that the shot blasting was } \\
\text { effective at decontaminating those concrete surfaces that were } \\
\text { accessible by the shot blasting equipment. (Ramachandran 1992) }\end{array}$ \\
\hline 1994 & $\begin{array}{l}\text { Electro-Osmotic } \\
\text { Pulse } \\
\text { (Dry-Tec of } \\
\text { North America) }\end{array}$ & $\begin{array}{l}\text { INEL: concrete } \\
\text { decontamination } \\
\text { scoping tests }\end{array}$ & $\begin{array}{l}\text { Unknown; preliminary testing of the process } \\
\text { showed migration of contaminants out of the } \\
\text { concrete; however, the results were incon- } \\
\text { clusive as to the overall effectiveness of the } \\
\text { technology, Setup and labor requirements } \\
\text { are minimal; however, treatment time can be } \\
\text { lengthy. }\end{array}$ & $\begin{array}{l}\text { INEL's use of Electro-Osmotic Pulse is in the preliminary stages of } \\
\text { technology development for concrete decontamination and showed } \\
\text { that although contamination can be removed from concrete, more } \\
\text { study is needed to determine the optimal conditions for removal. The } \\
\text { primary concern with the system is how much moisture is in the } \\
\text { concrete. The system has great potential and further testing would } \\
\text { help define the best way to set up the system and its limitations. } \\
\text { (Archibald 1995) }\end{array}$ \\
\hline
\end{tabular}


Table 2.7. (continued)

\begin{tabular}{|c|c|c|c|c|}
\hline Date & Technology & Site & Result & Comments \\
\hline 1989 & Hydraulic spaller & $\begin{array}{l}\text { PNL: Bldg. } 324 \text { and } \\
325 \text {, cock cover block } \\
\text { air locklacement }\end{array}$ & $\begin{array}{l}\text { Good; a hydraulic spaller was used to remove } \\
\text { a contaminated concrete surface with } \\
\text { radioactivity ranging from } 1100 \text { to } 22,000 \\
\text { mrad/h. The resulting surface was re- } \\
\text { grouted, and a stainless steel covering was } \\
\text { placed over the surface. }\end{array}$ & $\begin{array}{l}\text { The savings in radiation exposure as a result of this action is estimated } \\
\text { at } 7200 \text { mrad for personnel completing burial box runs for the } 324 \\
\text { and } 325 \text { Building Hot Cell Cleanout Program. Radiation exposure to } \\
\text { all staff members entering the air lock is now at least 50\% lower. } \\
\text { (Katayama et al. 1989) }\end{array}$ \\
\hline 1982 & Concrete spaller & PNL & $\begin{array}{l}\text { Good; the concrete spaller can remove up to } \\
100 \mathrm{ft}^{2} / \mathrm{h} \text { of concrete to a depth of } 1 / 2 \mathrm{in} \text {. }\end{array}$ & $\begin{array}{l}\text { The concrete spaller requires } 2 \text { operators to drill the holes and operate } \\
\text { the spalling device. Removal costs can be as low as } \$ 3.00 / \mathrm{ft}^{2}(1982 \\
\text { dollars). A vacuum system is utilized to remove the drilling-generated } \\
\text { dust. (Halter et al. 1982) }\end{array}$ \\
\hline 1982 & Water cannon & PNL & $\begin{array}{l}\text { Good; the water cannon consists of a } .458 \\
\text { magnum rifle that fires a small glycerine stick } \\
\text { into the concrete surface, removing up to } 9.5 \\
\mathrm{ft}^{2} / \mathrm{h} \text { to a depth of up to } 1 / 2 \text { in. }\end{array}$ & $\begin{array}{l}\text { The glycerine stick water cannon requires } 3 \text { operators, but is compact } \\
\text { and easy to handle, allowing it to be used in small, hard to reach } \\
\text { locations. Removal cost was estimated at } \$ 17.75 / \mathrm{ft}^{2} \text { (1982 dollars). } \\
\text { (Halter et al. 1982) }\end{array}$ \\
\hline
\end{tabular}

HEPA = high-efficiency particulate air (filter)

$\mathrm{HP}=$ health physics 
Table 2.8. Total and contaminated surface areas for structures at NRC reference sites

\begin{tabular}{|c|c|c|c|c|c|}
\hline \multirow{3}{*}{$\begin{array}{l}\text { Reference } \\
\text { facility }\end{array}$} & \multirow{3}{*}{$\begin{array}{l}\text { Structures' } \\
\text { radionuclide } \\
\text { activity, } \\
\text { dpm } / 100 \mathrm{~cm}^{2}\end{array}$} & \multicolumn{4}{|c|}{ Structures' surface areas ${ }^{b}$} \\
\hline & & \multicolumn{2}{|c|}{$\mathrm{ft}^{2}$} & \multicolumn{2}{|c|}{ Contaminant $\%$} \\
\hline & & Floor & Wall & Floor & Wall \\
\hline Power reactor & $7.5 \times 10^{6}{ }^{60} \mathrm{Co}$ & 250,000 & 300,000 & 10 & 2 \\
\hline Test reactor & $2.4 \times 10^{4137} \mathrm{Cs}$ & 100,000 & 120,000 & 10 & 2 \\
\hline Research reactor & $\begin{array}{r}102,000^{60} \mathrm{Co} \\
33,300^{137} \mathrm{Cs}\end{array}$ & 35,000 & 40,000 & 10 & 2 \\
\hline $\begin{array}{l}\text { Uranium fuel } \\
\text { fabrication }\end{array}$ & $18,000 \mathrm{U}$ & 240,000 & 240,000 & 50 & 5 \\
\hline Hexafluoride & $1.1 \times 10^{6} \mathrm{U}$ & 120,000 & 130,000 & 50 & 45 \\
\hline $\begin{array}{l}\text { Sealed source } \\
\text { manufacturer }\end{array}$ & $\begin{array}{r}102,0000^{60} \mathrm{Co} \\
33,300{ }^{137} \mathrm{Cs} \\
\end{array}$ & 6,000 & 4,600 & 10 & 5 \\
\hline Rare metal extraction & $18,000 \mathrm{Th}$ & 150,000 & 180,000 & 40 & 10 \\
\hline $\begin{array}{l}\text { Broad R\&D facility } \\
\text { (generic) }\end{array}$ & $\begin{array}{r}102,000{ }^{60} \mathrm{Co} \\
33,300{ }^{137} \mathrm{Cs}\end{array}$ & 6,000 & 4,600 & 10 & 5 \\
\hline Uranium mill & $1.1 \times 10^{6} \mathrm{U}$ & 100,000 & 130,000 & 100 & 100 \\
\hline $\begin{array}{l}\text { Dry independent spent- } \\
\text { fuel storage installation }\end{array}$ & $\begin{array}{l}980^{60} \mathrm{Co} \\
310^{137} \mathrm{Cs}\end{array}$ & 23,000 & 0 & 10 & -- \\
\hline
\end{tabular}

\section{Source: NRC 1994a}

- Radionuclide activity shown is for building surfaces.

$\checkmark$ The estimated surface areas are based on very limited information and in many cases, represent an engineering judgement estimate based on the size of the building structural facilities and types of operations. The estimates are believed to be conservatively large, i.e., probably overestimate the actual areas involved. 
Table 2.9. DOE concrete decontamination technology needs

\begin{tabular}{|c|c|c|}
\hline Technology need & Explanation & Applicable sites \\
\hline Reduction of secondary waste & $\begin{array}{l}\text { Large volumes of scabbled material created by } \\
\text { decontamination pose disposal problems. } \\
\text { Technologies capable of washing and leaching } \\
\text { contamination from rubble are desired. }\end{array}$ & $\begin{array}{l}\text { FEMP } \\
\text { ORR K-25 } \\
\text { ORNL }\end{array}$ \\
\hline $\begin{array}{l}\text { Less labor-intensive, time- } \\
\text { consuming methods }\end{array}$ & $\begin{array}{l}\text { Labor involved in the traditional scabbling } \\
\text { methods creates high costs in decontamination. }\end{array}$ & All sites \\
\hline Recycling of concrete & $\begin{array}{l}\text { Potential to reuse concrete rubble requires } \\
\text { technologies to ensure that the material can be } \\
\text { released. }\end{array}$ & $\begin{array}{l}\text { INEL } \\
\text { LBL }\end{array}$ \\
\hline Remote decontamination & $\begin{array}{l}\text { In order to reduce worker exposure to high levels } \\
\text { of radiation present at facilities, remote methods } \\
\text { are desired. }\end{array}$ & $\begin{array}{l}\text { HANF } \\
\text { INEL reactors } \\
\text { ETEC } \\
\text { SRS }\end{array}$ \\
\hline $\begin{array}{l}\text { Size reduction of large blocks } \\
\text { of concrete }\end{array}$ & $\begin{array}{l}\text { Unlike rubble, which has various potential } \\
\text { reuses, large blocks of concrete must be reduced } \\
\text { before any potential reuse }\end{array}$ & HANF \\
\hline $\begin{array}{l}\text { Decontamination of deeply } \\
\text { contaminated concrete, } \\
\text { including joints and cracks }\end{array}$ & $\begin{array}{l}\text { The majority of traditional concrete } \\
\text { decontamination methods are not effective for } \\
\text { deep contamination. }\end{array}$ & $\begin{array}{l}\text { FEMP } \\
\text { ANL } \\
\text { BCL }\end{array}$ \\
\hline $\begin{array}{l}\text { Decontamination of mercury- } \\
\text { contaminated concrete }\end{array}$ & $\begin{array}{l}\text { Mercury penetrates concrete to depths where } \\
\text { traditional methods are not effective. }\end{array}$ & $\begin{array}{l}\text { ORR Y-12 } \\
\text { ORNL } \\
\text { WSS }\end{array}$ \\
\hline $\begin{array}{l}\text { Decontamination of tritium- } \\
\text { contaminated concrete }\end{array}$ & $\begin{array}{l}\text { Tritium penetrates concrete to depths where } \\
\text { traditional methods are not effective. }\end{array}$ & $\begin{array}{l}\text { SRS } \\
\text { MND } \\
\text { LANL } \\
\text { INEL } \\
\text { PPPL } \\
\text { ORNL }\end{array}$ \\
\hline $\begin{array}{l}\text { Characterization/separation/ } \\
\text { segregation process }\end{array}$ & $\begin{array}{l}\text { A process where contaminated concrete is } \\
\text { identified, segregated, and cleaned during } \\
\text { dismantlement for recycling/reuse is needed. }\end{array}$ & $\begin{array}{l}\text { LBL } \\
\text { LANL }\end{array}$ \\
\hline
\end{tabular}

Sources: U.S.DOE 1993a and Appendix A 


\section{Candidate Technologies for Concrete Decontamination}

\subsection{Introduction}

Prior to evaluating and screening candidate technologies for concrete decontamination, a list of candidate technologies was required. This list was developed through assimilation and integration of information obtained from literature reviews, from personal inquires of commercial technology vendors and technology researchers and developers, and from prior experience of individual project team members. This task focused on compiling existing information (e.g., technology logic diagrams) in an effort to minimize duplication of past efforts. Although it was the focus of this task to look at emerging and/or innovative technologies, commercially available technologies were also included for completeness. This section reviews the process used to develop the preliminary candidate technology list and briefly describes the candidate technologies. It is important to note that efforts are continuing to investigate and include other technologies that may not be presented here.

\subsection{Methods}

The existing literature was searched for technology information that identified treatment options and constraints potentially applicable to concrete decontamination. Literature searches, targeting international as well as domestic technology development activities, were conducted in several data bases: the EPA ATTIC data base, Uncover, the DOE RAPIC data base, and DIALOG. Searches were structured to look for references specific to radionuclide-contaminated concrete and to decontamination methods (emerging and commercially available) applicable to concrete. Key DOE sources of information included the ORNL, K-25, and INEL logic diagrams (ORNL 1993; Oak Ridge K-25 Site 1993; INEL 1993, 1994), the Decommissioning Handbook (U.S. DOE 1993b), and previous DOE-funded efforts such as technology feasibility studies.

Technology R\&D activities within academia were surveyed by phone. A total of 41 universities were contacted (Table 3.1), with the initial contact targeting nuclear engineering departments. Additionally, 20 vendors that were queried responded with the concrete decontamination processes shown in Table 3.2. These processes can be subdivided into four broad types of treatment technologies: scabbling/scarification, chemical extraction, EK processes, and other emerging technologies. 


\subsection{Results and Discussion}

Preliminary lists of emerging and commercially available technologies with purported application to concrete decontamination were compiled and are shown in Tables 3.3 and 3.4. Fact sheets describing several technologies were prepared to enable rapid review and understanding of the technologies. These are presented in Appendix $\mathrm{C}$ and summarized in Tables 3.5 and 3.6. The information assembled includes: process description, number of successful remediations, treatment efficiencies, limiting conditions, processing rates, cost, and unusual environmental and worker health and safety concerns.

While gathering this information, no attempt was made to screen these technologies. In other words, emerging technologies have not been removed from consideration based on factors such as time before technology is ready for field application, likelihood of implementation, cost, etc. The technology fact sheets presented in Appendix $\mathrm{C}$ will be revised and updated as additional information from literature reviews, DOE site experiences, and commercial vendors becomes available.

Results of contacts with universities and brief descriptions of candidate technologies are presented in Sects. 3.3.1 through 3.3.5.

\subsubsection{Concrete Decontamination Research in Academia}

Searches and phone queries of academic researchers revealed that there is limited research of concrete decontamination. Observations resulting from the academic survey are summarized as follows:

- Few universities are currently conducting research with respect to concrete decontamination technologies. Many of the universities queried were unaware of the magnitude of the problem associated with radionuclide-contaminated concrete within the DOE complex.

- Surveys of universities that previously operated research reactors requiring decommissioning reported that facilities were typically demolished and disposed of without waste reduction or decontamination. In other words, the waste volume was not large enough to warrant decontamination, and it was easier to dispose of contaminated concrete rather than to decontaminate.

- The majority of the universities were unaware of any type of academic research being conducted with respect to concrete decontamination other than within the DOE complex (i.e., national laboratories). One university indicated that it would be difficult to manage the waste volumes created during large bench-scale tests. 
- Decontamination methods that have been used at universities where radionuclidecontaminated concrete was a problem included hand grinding or high-pressure water.

- Research on decontamination technologies (not necessarily limited to concrete or radionuclides) is currently being conducted at the following universities. Concrete decontamination research is relatively new to these institutions, and few investigators have published their findings.

1) Florida International University: microwave decontamination of concrete;

2) North Carolina State: chemical decontamination of stainless steel using surfactants;

3) Texas A\&M: electrolytic techniques for stainless steel, working with a Swedish company on cleaning the rinsate used in a Swedish decontamination process;

4) University of Florida: improving shot blasting with $\mathrm{CO}_{2}$ pellets;

5) University of Missouri: optimization of existing water-jet technology; and

6) University of Tennessee: chemical decontamination of metal surfaces containing oil and grease using non-hazardous solvents.

\subsubsection{Emerging Technologies}

The technologies discussed in this section are considered emerging, requiring additional research, development, evaluation, or testing prior to commercialization. These technologies were conceived and developed with the expectation that each technology would be more effective in a special situation than an existing, commercial technology. Because these technologies are at various stages of development and most have not been field-tested, a thorough description and evaluation of key parameters (e.g., processing rate, secondary waste generation, implementation, cost, removal efficiency) is not possible at this time. The brief descriptions of emerging processes applicable to concrete decontamination presented in this section were derived largely from the technology logic diagrams prepared at ORNL, ORR K-25, and INEL (ORNL 1993; Oak Ridge K-25 Site 1993; INEL 1993, 1994) and from the D\&D Handbook (U.S. DOE 1993b). These documents should be consulted for more detailed information.

\subsubsection{Biological Decontamination Technologies}

This method uses microbes to decontaminate concrete surfaces. Although biological processes are slow (months to years vs hours to days), they have the potential to significantly reduce both the secondary waste and man hours required for decontamination, offering benefits in situations where time is not a primary concern. 


\section{Biological Decontamination (Microbial-Influenced Degradation)}

This emerging technology has been laboratory-tested at INEL using living organisms to remove surface contamination (M. A. Hamilton, INEL, personal communication with Kathryn Dickerson, ORNL, 1995). The microorganisms used in the process at INEL, Thiobacilli, produce mineral acids that dissolve or disintegrate the concrete matrix. Organisms are introduced to form a uniform covering of the surface, probably through a spray or fine mist. Conditions to promote bacterial activity - temperature and relative humidity-are maintained for optimum microorganism growth, with periodic addition of mineral salts and nutrients. After several months (or up to several years), the surface is allowed to dry, terminating the microorganism growth. The remaining biomass and "rubble" is then removed by brushing or vacuuming. The technology is likely to work if methods can be developed to apply a layer of microbes to surfaces to be decontaminated, to supply needed nutrients to the microbes, and to remove the microbe layer from the decontaminated surface (ORNL 1993). This method may possibly be applied in situations where other technologies cannot be used (e.g., areas that are inaccessible to other technologies) or in situations where clean-up time is not a primary factor. Secondary-waste generation is minimal, consisting of the contaminated layer of microbes removed from the treated surface.

\subsubsection{Chemical Treatment Technologies}

These methods employ reactions with contaminants to form species that dissolve in the cleaning solution and are thereby removed from the substrate. Chemical surface-removal technologies may have potential use for concrete decontamination, but are most applicable to decontamination of metals. Therefore, a complete listing of technologies is not presented in this report [e.g., organic and inorganic acid treatments and reduction-oxidation (redox) treatments are not discussed].

\section{Chemical Gels}

Chemical gels are applied to remove smearable contamination from surfaces. Used as a carrier of chemical decontamination agents, not as the agent itself, the gel is sprayed onto component walls; allowed to react; and then scrubbed, wiped, rinsed, or peeled off. Solutions with viscosities of 300 to 600 centipoises form a reasonably stable film on the contaminated surface. An airless compressor can be used for spraying the gel and, with a change in heads, for rinsing. Typical reagent combinations are a nitric-hydrofluoric-oxalic acid mixture and a non-ionic detergent mixed with a carboxymethylcellulose gelling agent, with aluminum nitrate used as a fluoride chelating agent. Steps include scraping and vacuuming of solid waste material, preliminary hot-water rinsing, and gel spraying throughout the cell. After spraying and rinsing the gel film two or three times, the volume of waste to be neutralized was four or five times less than when using chemical solutions such as nitric acid. The acidic and basic wastes can be treated by phosphate precipitation, sulfate precipitation, simple neutralization, or neutralization and addition of nickel ferrocyanide precipitate (Harris et al. 1982). 
Chemical gels are most suited to in situ decontamination of large surfaces (Harris et al. 1982). They work well for in situ removal of smearable contamination from large components, with generation of minimal secondary waste (Costes et al. 1988). However, gels are complex systems that require laboratory optimization for changes in operating variables. They are costly and time-consuming for decommissioning but possibly worthwhile for maintenance and cleaning operations. Reagent action is limited by the solution viscosity, which reduces the ion diffusion rate at the gel-surface interface. The amount of active reagents in gel film must be kept low $\left(<10 \mathrm{~g} / \mathrm{m}^{2}\right)$.

\section{Chromographic Strippable Coatings (SensorCoat)}

This emerging technology developed at LANL is similar to commercially available strippable coatings with the addition of a colormetric indicator for decontamination of uranium, plutonium, and lead (B. Jorgensen, LANL, personal and written communication with Kathryn Dickerson, ORNL, 1995). Plans are in progress to develop a series of coatings that will be effective for a variety of conditions and contaminants. The SensorCoat strippable coating is a water-based, nontoxic polymer system that forms strong elastic films that are easily peeled from surfaces. The coatings indicate the contaminated areas by changing color where contamination is present. After drying, the coating is stripped, removing the contamination from the surface. By identifying areas of contamination during coating application, SensorCoat may minimize the area decontaminated compared to existing technologies that remove the entire surface to a specified depth over an area (including clean areas). Preliminary testing of SensorCoat indicates better decontamination factors compared to commercial coatings.

\section{Decontamination and Recycle of Concrete}

This integrated system has two major subsystems, one for decontamination and one for separation, including collection and treatment of all waste streams. The decontamination subsystem includes: dry vacuum cleaning with HEPA filtration, dust collection, foam cleaning agent application, low- and high-pressure surface rinsing, and surface concrete removal using highpressure water (METC 1994a). The separation subsystem provides coarse solids screening, oil and grease collection, fine solids removal, and organic compound removal using activated carbon. A full-scale demonstration of the process concept is planned for FY95.

\section{EK Process}

This technology removes contaminants using an electric potential to cause ion migration from the pores of the concrete into an electrolytic solution that may be subsequently treated by traditional volume-reduction methods (Morgan and Gilbert 1994; Bostick et al. 1993). This process leaves the surface intact and usable. The process has been demonstrated on concrete, and a patent has been applied for by ORR K-25 developers (Bostick et al. 1993). 
The method may be applied as a portable technology on select areas, with the solvent and electricity being applied to a localized spot. Significant contamination reductions $(>90 \%)$ have been shown during the demonstration of the technology on a small scale at ORR (Morgan and Gilbert 1994; Bostick et al. 1993; Lomasney 1993). A typical decontamination procedure begins with the construction of a dike around the area of contamination. An electrode is placed in the area behind the dike, which is filled with sufficient electrolyte material to submerge the electrode. The electrolyte is used to enhance the electrical connection between the electrode and the pore water in the concrete as well as to provide conditions favorable for removal of the contaminant (e.g., $\mathrm{pH}$ or redox). The dike and electrode make up half of the electrical circuit, while a similar diked area and floor drain, or other conductive material such as reinforcing steel, serve as the other half of the circuit. Waste generated by electromigration, if solvent recycle is included, may typically be loaded on ion exchange resin.

Several aspects of this method are being investigated, for example, selection of the best characteristics of the electrolyte in order to produce migration of all contaminants to the surface, concrete imbibing studies that evaluate the flow or migration mechanism, and a reliable test system to allow parametric studies. Evaluation of optimal parameters has not been successful because a reliable test system remains to be developed.

\section{Electro-Hydraulic Scabbling}

This technique delivers strong pulses to the concrete surface by powerful, controlled shock waves originated by a pulsed, high-voltage electric discharge (METC 1994b; Goldfard 1993). The hydraulic shock wave is propagated through water between the discharge channel and the concrete. In the electro-hydraulic scabbling head, the electric discharge occurs between two electrodes. Shock waves propagating through the water layer cause the concrete to crack and peel. The water provides transfer of energy and acts as a debris retainer. The electro-hydraulic scabbling system is currently undergoing testing, with an on-site demonstration planned in early FY96. The depth of scabbling will be controlled by changing the pulse shape and energy and the electrode position. The system is currently being designed to be a robotically operated process that will generate minimal secondary waste.

\section{Solvent Washing}

Mainly applicable to smearable contamination, solvent washing uses an automated system to spray and recover the solvent (Allen et al. 1981). Less environmentally toxic solvents need to be identified and demonstrated (ORNL 1993). Plutonium-contaminated items at Richland, Washington, were rinsed with Freon (ORNL 1993). However, the vendor no longer supplies the equipment that was used at Richland ten years ago (Allen 1984). Additionally, solvent washing to remove organic contaminants (solvent degreasing) was used successfully at the $\mathrm{K}-25$ Site, but was discontinued to avoid exposing workers and the environment to the hazardous solvents. Other solvents might be available, but their effectiveness would have to be demonstrated (ORNL 1993). 


\subsubsection{Mechanical Surface Removal Technologies}

Numerous variations of mechanical impact processes are commercially available, including grit blasting, shot blasting, plastic pellet blasting, and various $\mathrm{CO}_{2}$ blasting methods. Because these technologies remove the surface layer, $100 \%$ decontamination should result if the depth of penetration by the removal device is greater than the depth of contamination. Typically, waste generated by these technologies includes the blasting medium (if not separated from the waste) and the removed surface. Thus, technology improvements include waste minimization, handling, and treatment.

\section{Supercritical $\mathrm{CO}_{2}$ Blasting}

Supercritical $\mathrm{CO}_{2}$ (above its critical temperature of $87.8^{\circ} \mathrm{F}$ and at high pressure) is pressurized by an ultrahigh-pressure intensifier pump to $55,000 \mathrm{psi}$ and forced through nozzles, generating high velocity $\mathrm{CO}_{2}$ jets at speeds up to $3,000 \mathrm{ft} / \mathrm{s}$ (ORNL 1993). The nozzles may be mounted in different cleaning heads for various contaminated surfaces. The $\mathrm{CO}_{2}$ jets thoroughly penetrate and remove surface contaminants without damaging the healthy substrate. The removed contaminants, the $\mathrm{CO}_{2}$, and any of the substrate surface layer that has been removed are captured by a vacuum recovery system. In the recovery system, the contaminants and the substrate surface layer, if removed, are collected by a cyclone separator and a HEPA filter. The $\mathrm{CO}_{2}$, now in the gaseous state, is discharged to the atmosphere or recovered and recycled to the supercritical cleaning step. This technology, being developed by a private company, needs evaluation regarding the effect of operating parameters (e.g., pressure, distance between nozzle and substrate, traversing speed of cleaning head).

\subsubsection{Thermal Removal Technologies}

With these techniques, the surface layer is removed, and $100 \%$ decontamination should result if the method is applied until a layer below the contamination is removed. Typically these technologies produce minimal waste. However, thermal surface removal produces smoke containing small particles that are more difficult to remove by filtration than the dusts resulting from mechanical surface removal.

\section{Dry Heat Roasting}

This technology is evolving and currently at the problem-definition stage. The technology is simple in concept; however, its application for surface decontamination has not been demonstrated. Because no substrate is removed, the waste generated could potentially be minimal. No further information is available at this time. 


\section{Flashlamp Cleaning}

Using this technique, energy from a high-energy xenon flashlamp is absorbed at the surface, and the ensuing rapid temperature rise vaporizes material or decomposes it to a particulate residue (D. J. Flesher, Westinghouse-Hanford Laboratory, Hanford, Washington, personal communication with D. B. Smith, ORNL, 1993) (TTP CH101102, FY92). Radiological decontamination using high-energy xenon flashlamps is in the demonstration phase. The method is capable of removing contaminants at the surface or at very shallow depths below the surface. The primary application for flashlamp cleaning is to large surface areas that need a high degree of decontamination with the absolute minimum amount of waste. The technology produces as waste only the material that is removed from the surface (all the vaporized material is collected in a filtration system).

\section{Laser Etching and Ablation}

Laser etching and ablation are methods for removing contaminants at the surface or at very shallow depths below the surface (Freiwald 1994). Energy from pulsed laser beams is absorbed at very shallow depths below the surface, and a combination of photochemical and photothermal effects causes thin layers of material to be rapidly ejected from the surface (M.C. Edelso, Ames Laboratory, Ames, Iowa, personal communication with D. B. Smith, ORNL, 1993; Pang et al. 1992a; Pang et al. 1992b). Thus, laser ablation is not strictly a thermal effect. As with laser heating, this technology produces a minimal amount of waste. The primary waste produced is the material removed from the surface, which is collected in a filtration system. Several research groups and national laboratories have used the technology to remove radiological and organic contaminants from a variety of surface types. HANF is conducting laboratory and field tests of a prototype laser-based decontamination system (TTP CH101102, FY92). The method needs additional laboratory study before a technology demonstration can be performed. The versatility and effectiveness of the technique have been demonstrated, and the hardware and other materials required for implementing the technique (e.g., lasers, optics, vacuum and filtration systems) already exist.

\section{Laser Heating}

Laser heating removes contaminants at the surface or at very shallow depths below the surface. Energy from a continuous-wave or pulsed laser is absorbed at the surface, and the rapid temperature rise causes material to evaporate or decompose to a carbonaceous residue. Large surface areas needing a high degree of decontamination with the absolute minimum amount of waste generation are ideal for this technique. The technology produces only the material that is removed from the surface as waste, all vaporized material being collected in a filtration system. Laser-based photothermal heating is currently being considered by the military as a method for removing organic coatings (e.g., polyurethane paint) from metal and composite surfaces. A prototype paint-removal system was built by BDM International and is now being 
tested by the U.S. Air Force. This system uses a $\mathrm{CO}_{2}$ laser-based system to remove a 2-mmthick coating of paint at a rate of about $2.5 \mathrm{ft}^{2} / \mathrm{min}$ (D. J. Flesher, Westinghouse Hanford, personal communications with D. B. Smith, ORNL, July 7, 1992 and May 14, 1993).

\section{Microwave Scabbling}

In this cleaning process, microwave energy directed at a concrete surface using a specialized waveguide applicator heats both the concrete and free water present in the concrete matrix (ORNL 1993; INEL 1994). Continued heating produces thermal- and steam-pressureinduced mechanical stresses that cause the concrete surface to burst ( $\mathrm{Li}$ et al. 1992a, 1992b). The concrete particles from this steam explosion are small enough to be removed by a vacuum system, yet less than $1 \%$ of the debris is small enough to pose an airborne contamination hazard. The process is fast, dry, generates little dust, and avoids mechanical impacts. The microwave applicator head may be manually moved about on the concrete surfaces being decontaminated; the rate and depth of surface removal depends on the applicator translation speed.

Removal of noncontaminated concrete surfaces using microwave energy was demonstrated at ORNL (White et al. 1992). At microwave frequencies of $2.45 \mathrm{GHz}$ and $10.6 \mathrm{GHz}$, continuous concrete removal rates of $0.067 \mathrm{in} .3 / \mathrm{s}$ at $5.2 \mathrm{~kW}$ and $0.13 \mathrm{in} .3 / \mathrm{s}$ at $3.6 \mathrm{~kW}$ were obtained. Removal rate and removal depth are controlled by modulating frequency, power, and translation speed of the applicator on the concrete surface. Higher frequencies preferentially remove surface contamination. A mobile, prototype microwave concrete removal machine was built at ORNL during FY92 and FY93. A rugged, compact, and electrically efficient microwave applicator that is better integrated with the required concrete debris collection system is being developed (TTP OR101204). In 1987, a group from Japan reported on a mobile microwave decontaminator that could perform removal at a rate of $0.67 \mathrm{in} .{ }^{3} / \mathrm{s}$, matching the fastest commercial mechanical concrete-breaking machines (Yasunaka et al. 1987). It is anticipated that, with an upgrade of power and improvements to the applicator design to spread out the microwave power in a larger area, concrete removal rates comparable to or exceeding those obtained with conventional concrete removal equipment can be achieved (T. L. White, ORNL, personal communication with J. H. Wilson, ORNL, TTP No. OR-3DAA, DOE No. OR-101204).

The microwave technique is a dry process that generates little dust. Because microwave scabbling removes the contaminated concrete surface, the decontamination efficiency should be $100 \%$ if there is no recontamination from the removed scabble. Concrete rubble with particle diameters of 0.4 to $4 \mathrm{in}$. is generated. The quantity of waste depends upon the translation speed of the microwave applicator and the depth of the concrete surface layer removed. For example, a removal depth of $4 \mathrm{in}$. and a surface-area treatment rate of $1 \mathrm{ft}^{2} / \mathrm{min}$. yield $150 \mathrm{lb} / \mathrm{h}$ of concrete waste. 
The development and testing of a mobile prototype microwave concrete removal machine needs to be completed (TTP OR101204). Remote operation will necessitate the adaptation of the mobile microwave and vacuum collection systems to a robotically controlled system. In addition, the development of real-time monitoring sensors for measuring the progress of the decontamination process is needed so that only the contaminated portion of the concrete is removed, thus minimizing the amount of waste produced.

\section{Plasma Torch}

Using an inert gas passing through a high-powered DC or RF arc discharge, this technique produces a very high temperature gas stream that is capable of melting nearly all uncooled materials (Hollis 1983). Such torches, used in plasma synthesis and decomposition of materials, can operate with either an inert gas like argon or an active gas. In the inert-gas mode, no significant addition to the waste stream is expected because gas flow from the torch would be on the order of $10 \mathrm{ft}^{3} / \mathrm{min}$. Waste would be converted to a gaseous form and collected in a standard HEPA filtration system. In the active-gas mode, the operating gas would most likely combine with the waste, forming new material. This new material, also in gaseous form, would be handled with existing HEPA filtration systems. The inert gas is recyclable and creates no additional waste stream of its own, as compared to the $\mathrm{CO}_{2}$ and $\mathrm{NO}_{\mathrm{x}}$ products created by a combustion torch.

Plasma torches exist commercially to weld and cut materials that either have very high melting temperatures or require an inert atmosphere to prevent oxidation. The plasma torch method has potential uses for rapid spalling of concrete and using the difference in coefficient of thermal expansion to delaminate contaminants from underlying substrates. While plasma torch technology exists, its efficacy in removing various organic and radioactive contaminants has not been demonstrated. Elevation to the predemonstration stage requires laboratory-scale experiments.

\subsubsection{Commercial Technologies}

Technologies discussed in this section are considered commercial and, therefore, readily available (i.e., field tested and available from private industry vendors). Commercial technologies considered to be baseline technologies for comparison purposes are: washing of surfaces with transferrable contamination, mechanical scabbling for large surfaces (i.e., floors), needle gun scabbling and/or high pressure washing for walls and ceilings, and jack-hammering for cracks and penetrations. The brief descriptions of commercial processes applicable to concrete decontamination presented in this section were derived largely from the technology logic diagrams prepared at ORNL, ORR K-25, and INEL (ORNL 1993; Oak Ridge K-25 Site 1993; INEL 1993, 1994) and the D\&D Handbook (U.S. DOE 1993b). These documents should be consulted for more detailed information. 


\subsubsection{Chemical Treatment Technologies}

These methods employ reactions with contaminants to form species that dissolve in the cleaning solution and are thereby removed from the substrate. As stated previously, chemical surface-removal technologies may have potential use for concrete decontamination, but are most applicable to decontamination of metals.

\section{Chemical Foams}

Used to remove smearable contamination from contacted surfaces, chemical foams are widely employed throughout the nuclear industry. Foam is used as the carrier of chemical decontamination agents (in the early 1980s, detergents and wetting agents), not as the agent itself (Harris et al. 1982; Costes et al. 1988). It is sprayed onto component walls, or the component is filled with the foam. For vertical surfaces, decontamination agents are suspended in a thick, dry foam that is applied to the surface to be cleaned. Ideally, a light, even coating is formed ( 1 to 2 in. thick), with a residence time on vertical surfaces of at least several minutes. It can be sprayed on and wiped, rinsed, or vacuumed off. Repeated applications can reduce surface contamination by several orders of magnitude (ORNL 1993). The waste produced includes small amounts of contaminated sulfonated detergents, synthetic wetting agents, coupling agents, rinse water, and drying cloths. Chemical foams are a good method for large areas with complex shapes. However, it may be difficult to keep foam circulating while integrally filling large cavities. Furthermore, it is not appropriate for use on cracked surfaces or those with deep or convoluted crevices.

\section{Detergent Treatment}

Detergent treatment uses alkaline sodium carbonate, ammonium carbonate, sodium ethylenediaminetetraacetic acid (EDTA), sodium citrate, trisodium phosphate, other sequestering agents, and detergents for surface washing and removal of particulates (Swan et al. 1987). This process, which has been shown to work, removes surface smearable decontamination with caustic chemicals (essentially soap and water scrubbing). Moderate quantities of contaminated caustic solutions are produced. Simple neutralization and precipitation have been the traditional treatment. The sludge produced must also be treated, typically by stabilization/solidification.

\section{Chelation}

Chelation technologies employ selective removal of organic and inorganic compounds by chemical dissolution with organic chelating agents such as carboxylic acids (Nutek 1977; Bouchard and D'Muhala 1993). The technology has been employed at various facility operations and nuclear power plant sites, achieving acceptable decontamination levels 
resulting in unconditional release. The agent breaks the chemical bond between the contaminant ion and the contaminated item, forming a soluble complex. Additional reagents, such as surfactants and emulsifiers, can be added, depending on the situation. Current validation of updated chelating agents is underway at ORNL to confirm total efficacy and economic advantages. The technology differs from solvent extraction in that an acid solution is not required (reaction occurs at near-neutral $\mathrm{pH}$ ). Both loose and fixed contamination can be removed using these agents with either batch or continuous processes (using optional ultrasonic agitation), a spray booth, or through in situ application by a wet-vacuum cleaning machine (Ayers 1970; ORNL 1993). Chelating agents can be destroyed in solution, producing a filterable sludge containing the contaminant. Waste products from chelate solution are nonhazardous and nonfuming, do not evolve gas, and are biodegradable. The technology minimizes waste through oxidative destruction of chelate agents, partitioning of organic compounds (including PCBs), and concentration of radionuclides precipitated out in the flocculent sludge, which can be further dewatered. Oxidation of chelating agents removes any potential for mixed-waste classification from that source.

\section{Strippable Coatings}

Used for removing hazardous and/or radioactive contaminants, this method uses a coating, such as a water-based organic polymer, applied to a contaminated surface by spraying, brushing, or rolling (as may be used for paint) at typically $50 \mathrm{ft}^{2} / g a l$ of polymer (ORNL 1993). When the coating dries, it is either manually stripped from the surface or in the case of autorelease coatings, is collected by vacuuming. Surface contamination is removed with the coating, producing a dry, hard, non-airborne waste product. Water-based strippable coatings are intended for use in decontaminating smooth and semi-rough porous surfaces, including steel, concrete, aluminum, wood, and painted surfaces. Strippable coatings are very effective; however, application and removal times are relatively long in some instances, cost of materials is high, and the radioactive waste aspects for disposal must be carefully considered. Most commercial strippable coatings may be incinerated.

\subsubsection{Mechanical Surface Removal Technologies}

Numerous variations of mechanical impact processes are commercially available, including grit blasting, shot blasting, plastic pellet blasting, and various $\mathrm{CO}_{2}$ blasting methods. Because these technologies remove the surface layer, $100 \%$ decontamination should result if the depth of penetration by the removal device is greater than the depth of contamination. Typically, waste generated by these technologies includes the blasting medium (if not separated from the waste) and the removed surface. Thus, technology improvements include waste minimization, handling, and treatment. 


\section{Cryogenic $\mathrm{CO}_{2}$ Pellet Blasting}

$\mathrm{CO}_{2}$ pellet blasting, using compressed air to accelerate the pellets, is a demonstrated and effective technology for decontaminating equipment at nuclear reactor sites without producing secondary wastes (ORNL 1993; INEL 1994). The use of centrifuge pellet acceleration has been established in the DOE Fusion Energy Program, where frozen deuterium and tritium are formed and accelerated for fueling fusion reactors (Foster 1983). This technology includes accelerating pellets of argon and $\mathrm{CO}_{2}$ for the purpose of cleaning heavy oxidation deposits from uranium surfaces as part of the DOE Y-12 waste minimization program (Foster 1991). Because the pellets evaporate to gaseous $\mathrm{CO}_{2}$ upon impact, the secondary waste stream is limited to the materials removed from the surface. During the blast, the contaminants are released to the surrounding air. A vacuum shroud surrounding the blast nozzle and covering the impact area could be used to produce a negative pressure and collect the airborne contaminants in a conventional HEPA filtering system. The secondary waste stream is thereby limited to the HEPA filters.

The fundamental concepts of a centrifugal pellet accelerator are well proven and have been demonstrated. The centrifugal-accelerator $\mathrm{CO}_{2}$ pellet blaster applies directly to numerous decontamination problems (concrete, painted concrete, concrete block, tiled concrete, stainless steel sheet, structural steel, steel plate, galvanized metals, and heavily oxidized metals). The only technology needs are those associated with tailoring the accelerator to the particular contamination problem. In most cases, this is accomplished simply by adjusting the pellet speed and determining the specific decontamination rate. In some contaminated environments, it may be desirable to detect the degree of contamination and develop feedback control that will speed the overall cleaning rate, thus reducing operating costs. Since the $\mathrm{CO}_{2}$ is a gas after impact, it can be collected in normal gas collection systems. The materials removed require only established collection technology.

\section{Compressed-Air Cryogenic $\mathrm{CO}_{2}$ Pellet Blasting}

This demonstrated technology is commercially available and has been used at nuclear reactor sites (ORNL 1993; TTI Engineering 1991). Compressed-air cryogenic $\mathrm{CO}_{2}$ pellet blasting is similar to traditional sandblasting except that pellets are solid $\mathrm{CO}_{2}$ (dry ice) instead of sand. Depending on the pellet impact velocity and the substrate material, the pellets clean by removing surface contamination or by removing/etching the substrate. Since the dry ice pellets evaporate on contact, secondary waste is minimized. The contamination removed from the surface is collected via a vacuum and HEPA filtration system, which is either a closely coupled shroud over the surface or a specially designed room air filtration system. The technology is known to be effective at removing smearable contamination, while the removal of fixed contamination depends on the nature of the bonding. For example, the technology can remove paint and loose rust but is not aggressive enough to etch steel or remove black oxide from steel. 


\section{$\mathrm{CO}_{2}$ Blasting}

This technology is a variation of grit blasting where $\mathrm{CO}_{2}$ (dry ice) pellets are used. Small, dry ice pellets are accelerated through a nozzle using compressed air at 50 to $250 \mathrm{psi}$ (U.S. DOE 1993b). A typical system consists of a pelletizer that converts liquid $\mathrm{CO}_{2}$ into dry ice and a cleaning station where the pellets are stored and blasted. The pellets shatter upon impact with the surface and instantly vaporize as they blast fragments of the surface loose. The loose fragments are collected for disposal, and secondary waste is minimized due to the conversion of $\mathrm{CO}_{2}$ to the gaseous phase. Hard coatings that bond very firmly to the base material may not be removed effectively by this technique.

\section{Grit Blasting}

Grit blasting, commonly known as sand blasting, is a readily available, pneumatic cleaning process using a wide variety of grits (ORNL 1993; INEL 1994). Typical abrasives include sand, glass beads, metallic beads, and soft materials such as nut shells and rice hulls. Grit blasting units have been used many times in the nuclear industry, with applications ranging from heavily contaminated pipework to lightly contaminated surfaces (ASM 1978; IAEA 1989). Highly abrasive grits will clean more effectively and faster than soft grits; both types ultimately become part of the waste stream. Waste production rates depend on the media/ surface combination but could range from 0.005 to $0.1 \mathrm{lb} / \mathrm{f}^{2}$, including grit plus filters. Technology improvements are needed in waste minimization related to blast medium erosion and disposal; containment of waste and vacuum systems; and demonstration of specific blastmedium substrate/contaminant capabilities, including determination of decontamination factors and process automation.

\section{High-Pressure Water}

In this method, contaminated surfaces are blasted with high-pressure water to remove deposits tightly adhered to substrate materials (ORNL 1993; INEL 1994). Water pressure at the nozzle of commercially available, high-pressure blasting systems is typically 5,000 to 20,000 psig, with flow rates varying from 4 to $>100 \mathrm{gal} / \mathrm{min}$. High-pressure water blasting has been used successfully to decontaminate various large and complex surfaces at nuclear power plants, including floor drains, sumps, and reactor cavity walls. The high-pressure-water cleaning head may be manually moved on the surfaces being decontaminated, with decontamination efficiency depending on the applicator translation speed and other operating parameters. The method may be used as a preliminary step for further decontamination. The waste generated is the contaminated water from the cleaning operation, which must be treated and prevented from spreading contamination. 


\section{Ice Blasting}

Ice blasting is similar to other decontamination technologies that direct a high velocity stream of fine particles, such as shot, grit, cryogenic pellets, or plastic pellets, onto a surface to remove contamination (INEL 1994). Ice blasting will remove coatings and some fixed surface contamination, but it will not remove concrete to a significant depth (ORNL 1993). The contaminated waste water generated by the melting ice particles is the controlling medium for the displaced contamination. The water must then be treated for discharge. Ice blasting technology has been used recently for decontamination at the Oconee Nuclear Power Plant in Seneca, South Carolina (ORNL 1993).

\section{Plastic Pellet Blasting}

Plastic pellet blasting is similar to sand blasting, but uses fewer abrasive plastic pellets. This technology is a widely used alternative to sand blasting for applications where it is desirable to remove surface contamination or contaminated coatings while imparting minimal damage to the substrate (ORNL 1993; INEL 1994). Cost of the medium is high ( $\$ 1$ to $\$ 2 / \mathrm{lb}$ ), and pellet erosion can be a factor. However, cyclone systems are capable of recycling pellets up to thirty times for reuse. Cleaning rates of up to $4 \mathrm{ft}^{2} / \mathrm{min}$ are quoted for a $1 / 2$-in. nozzle at $30 \mathrm{psi}$ (Abott 1991). The plastic medium has some advantages over grits, such as sand and metal shot, in that it may be more easily separated from the waste stream and disposed of by incineration; thus, there is potential to significantly reduce waste disposal costs. As with other blasting methods, technology improvements are needed in waste minimization related to blast medium erosion and disposal; containment of waste; and demonstration of specific blast-medium substrate/contaminant capabilities, including determination of decontamination factors and process automation.

\section{Scabblers/Scarifiers}

Scabbling/scarification has been used for numerous decontamination applications involving hazardous and radioactive contaminants. This technology decontaminates a concrete substrate by using mechanical impact methods to remove the contaminated surface (ORNL 1993; INEL 1994). Many commercial units use high-speed, reciprocating, tungsten carbide-tipped pistons to pulverize protective coatings, laitance, and concrete substrate in a single-step process (laitance is the accumulation of fine particles on the surface of freshly placed concrete occurring when there is an upward movement of water through the concrete). Other types of units use a shrouded, needle scaler to remove concrete from outside edges and inside corners, as well as from wall surfaces. Because the technology involves removal of contaminated surfaces, decontamination efficiency is estimated at $95 \%$ or higher. The waste generated is the pulverized surface layer, which is collected by a vacuum system. The amount of waste generated depends upon the depth of treatment. For example, two different commercial units provide removal of concrete at rates of 3 to $4.5 \mathrm{in.} . / \mathrm{min}(8$ to $12 \mathrm{lb} / \mathrm{h}$ ) and $60 \mathrm{in.} / \mathrm{min}$ 
$(160 \mathrm{lb} / \mathrm{h})$ at a removal depth of $1 / 16$ in. Mechanical scabblers are usually operated manually, but may be remote-controlled to generate more uniform removal rates or to treat high levels of radioactivity.

\section{Shot Blasting}

This commercially available process uses mechanically accelerated iron shot (pellets) (ORNL 1993; INEL 1994). After the shot hits the surface to be cleaned, it is recovered by a magnetic system and recirculated. Shot is recycled many times during cleaning, but ultimately erodes and becomes part of the waste stream (at the rate of approximately $0.1 \mathrm{lb} / \mathrm{m}^{2}$ ). Shot blasting differs from sand blasting in that it can be controlled to give more accurate results (ASM 1978). The process has been used as a one-step technique to prepare large areas of concrete floors before painting, for cleaning rust and marine growth from ship hulls, and for cleaning structural steel elements. A Wheelbrator Blastrac is being used to decontaminate floors at the ORR K-25 site. Cleaning rates for floors are quoted as being faster than acid etching, sandblasting, and scarifying by factors of 1.7, 1.3, and 2.0 respectively (ORNL 1993). Portable machines with design rates of $2,500 \mathrm{ft}^{2} / \mathrm{h}$ are available (ORNL 1993). This method is considered advantageous because it is commercially available and has seen considerable use for cleaning various surfaces (IAEA 1989). Use of the device will generate contaminated dust, gases, and/or fluids. Thus, waste minimization related to blast medium erosion and disposal, containment of waste, and demonstration of specific blast-medium substrate/contaminant capabilities, including determination of decontamination factors and process automation, should be addressed.

\section{Sponge Blasting}

This technology is relatively new and decontaminates by blasting surfaces with various grades of patented, water-based urethane-foam cleaning media, using $110 \mathrm{psig}$ air as the propellant (ORNL 1993). The cleaning heads of the unit are similar to those of other blasting technologies. The foam may be used dry or wetted for a variety of surface contaminants such as oils, greases, lead compounds, chemicals, and radionuclides (INEL 1994). Two types of foam cleaning media are used: (1) a nonaggressive grade that is used for surface cleaning of sensitive or otherwise critical surfaces; and (2) aggressive grades that are impregnated with abrasives that can remove tough materials such as paints, protective coatings, and rust (also roughening concrete and metallic surfaces if desired). Foam blasting media are recyclable in a closed-cycle wash unit that centrifugally launders the cleaning medium. The medium typically can be recycled eight to ten times. On the first application, the sponge blasting unit uses 6 to $8 \mathrm{ft}^{3}$ of medium per hour at a surface cleaning rate of about $1 \mathrm{ft}^{2} / \mathrm{min}$. The solid waste thus produced (foam medium with the absorbed contaminants) is approximately $0.01 \mathrm{ft}^{3} / \mathrm{t}^{2}$ of surface cleaned. For waste minimization purposes, the contaminated water from the wash unit can be treated and recycled. 


\section{Steam Cleaning}

Steam cleaning combines the solvent action of water with the kinetic energy effect of blasting (U.S. DOE 1993b; ORNL 1993; Oak Ridge K-25 Site 1993). At relatively high temperatures, the solvent action is increased, and water volume requirements are reduced (compared to water blasting). The technique has proven useful, especially on complex shapes and large surfaces where the steam cleaning head may be manually moved about on the surfaces being decontaminated. Decontamination efficiency depends on the applicator translation speed as well as on other operating parameters. The waste generated is the contaminated condensed steam from the cleaning operation. The issues of waste water treatment, volatilization of contaminants, and prevention of the spread of contamination must be addressed.

\section{Superheated Water}

This technology uses a high-velocity stream of superheated water (e.g., at conditions of $300 \mathrm{psi}$ and $300^{\circ} \mathrm{F}$ ) directed onto a surface to remove contamination (ORNL 1993; Oak Ridge K-25 Site 1993). The superheated water cleaning head may be manually moved about on surfaces being decontaminated. Also, a hand-held wand may be more conveniently used for vertical surfaces, equipment surfaces, etc. Because of the relatively low operating pressures (as compared to UHPW at 30,000 to $50,000 \mathrm{psi}$ ), superheated water will remove only surface contamination that is soluble or loosely bound to the surface. The waste generated is the contaminated water from the cleaning operation, which must be treated and prevented from spreading contamination. The waste water generation rate for a typical commercial unit ranges from 0.4 to $2 \mathrm{gal} / \mathrm{min}$.

\section{Ultrahigh-Pressure Water (UHPW)}

This technology is commercially available and has been used by industry. An ultrahighpressure intensifier pump pressurizes water up to 55,000 psi and forces it through smalldiameter nozzles, generating high-velocity water jets at speeds up to $3,000 \mathrm{ft} / \mathrm{s}$ (ORNL 1993). The nozzles may be mounted in various types of cleaning heads for different contaminated surfaces. In cleaning concrete, for example, a typical flow rate for one cleaning head would be 3 to $5 \mathrm{gal} / \mathrm{min}$ at a surface treatment rate of about $1 \mathrm{ft}^{2} / \mathrm{min}$ (ORNL 1993). The water jets thoroughly penetrate and remove surface contaminants. Although the technology can produce high levels of decontamination, the issues of waste-water treatment (contaminated water generated from the cleaning operation) and prevention of spread of contamination must be addressed. Nozzle configuration, water pressure and flow rate, distance of the cleaning head to the substrate, and the geometric complexities of the substrate are all parameters that need to be evaluated. 


\section{Water Flushing}

Low-pressure, hot- or cold-water flushing, used extensively at most DOE plants, dissolves readily soluble contaminants or flushes loosely deposited particles to a central area for collection (U.S. DOE 1993b). Flushing with hot or cold water often follows scrubbing, especially on floors or as a pretreatment for other decontamination processes. The technique is not effective on fixed, nonsoluble contamination but should be effective for transferrable contamination. The large amounts of waste water generated by the flushing operation must be treated and prevented from spreading contamination.

\section{Other}

Other mechanical methods include grinding, honing, scraping, milling, and explosives. Handheld, power-driven grinding equipment is used to remove the surface from the contaminated object. Grinding has been successfully used for small-scale decontamination. Conceptually, automated grinding may be remotely operated with power-driven grinding equipment to remove the top surface layer of a contaminated object, with a manipulator for turning and moving the contaminated item. Concrete milling shaves away the top layer of the concrete. Large milling vehicles used by paving contractors could potentially be used for large-area horizontal surfaces (Barbier and Chester 1980).

The top 3 to 4 in. of concrete can be removed by detonating carefully placed and timed explosive charges, a technique that has been used to decontaminate nuclear reactor shielding (Laguardia 1980). However, safety concerns need to be resolved: dust must be contained and structural damage prevented, both to the building being decontaminated and the surrounding structures (U.S. DOE 1991). The explosion will generate toxic organic vapors; thus, technology to control these vapors must be developed and demonstrated [J. Googin, written comments on draft of Oak Ridge K-25 Site Technology Logic Diagram (Oak Ridge K-25 Site 1993)]. Improvements in the methods of applying explosives and in the uniformity of the detonation are also needed (U.S. DOE 1991).

\subsubsection{Thermal Removal Technologies}

With these techniques, the surface layer is removed, and $100 \%$ decontamination should result if the method is applied until a layer below the contamination is removed. Typically these technologies produce minimal waste. However, thermal surface removal produces smoke containing small particles that are more difficult to remove by filtration than the dusts resulting from mechanical surface removal. 


\section{Flame Scarification}

This emerging technology applies controlled high-temperature flames to concrete surfaces, causing differential expansion and spalling (U.S. DOE 1993b; Ebeling et al. 1984). Pieces up to several inches in diameter are removed from the surface. Typical machine burners have widths up to $3 \mathrm{ft}$ and have been used for large surface areas. Hand-held burners up to 10 in. wide can be used for walls. Thermal decomposition of contaminants must be addressed prior to using this technology. 
Table 3.1. Universities queried regarding technology R\&D for D\&D

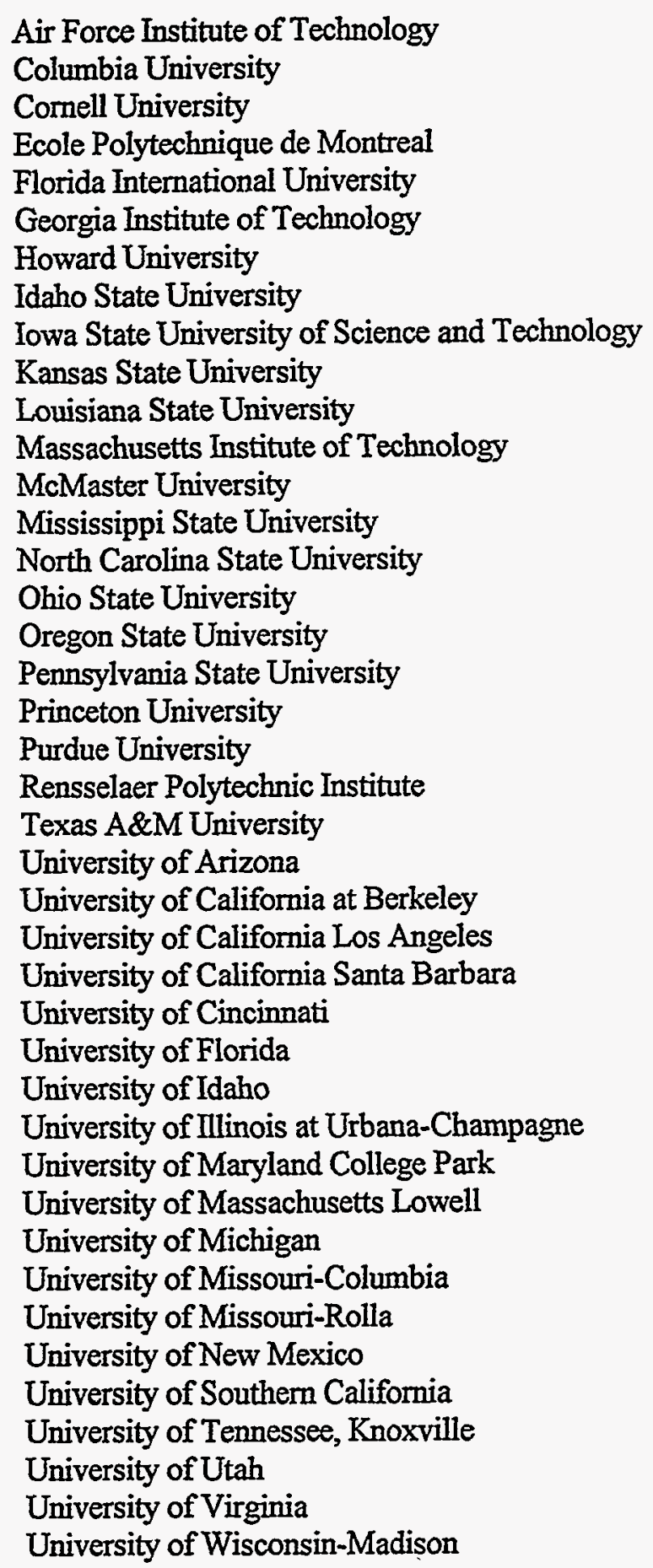




\section{3-21}

Table 3.2. Commercially available concrete $D \& D$ technologies based on vendor responses

\begin{tabular}{|c|c|c|}
\hline Company & Technology and comments & Contact \\
\hline Alaron ${ }^{2}$ & Chemical decontamination & $\begin{array}{l}\text { Ron Mencarelli, James Taylor } \\
803-791-9900\end{array}$ \\
\hline $\begin{array}{l}\text { American } \\
\text { Ecology }\end{array}$ & $\begin{array}{l}\text { Blasting, chemical decontamination } \\
\text { (former Quadrex facility in Oak Ridge) }\end{array}$ & $\begin{array}{l}\text { Val Louiselle, David Rye } \\
615-482-5532\end{array}$ \\
\hline $\begin{array}{l}\text { Applied Radio- } \\
\text { logical Controls } \\
(\text { ARC) }\end{array}$ & $\begin{array}{l}\text { Scabbling, chemical decontamination, } \\
\text { strippable coatings }\end{array}$ & $\begin{array}{l}\text { Bud Wyatt, Bob Leddy } \\
404-429-1188\end{array}$ \\
\hline Arrowjet & Soft-media blasting & $\begin{array}{l}\text { Brad Squibb, Steve Pocock, Mike Smith } \\
615-753-1388\end{array}$ \\
\hline Bartlett & Strippable coatings, chemical decontamination & $\begin{array}{l}\text { John Remark, Paul Lovendale, } \\
\text { Adrian Lombardo } \\
800-225-0385\end{array}$ \\
\hline Cold Jet & $\mathrm{CO}_{2}$ blasting (equipment at $\mathrm{Y}-12$ ) & $\begin{array}{l}\text { Chuck Price } \\
513-831-3211\end{array}$ \\
\hline $\begin{array}{l}\text { Corpex } \\
\text { Technologies" }\end{array}$ & Chemical decontamination, chemical supplier & $\begin{array}{l}\text { Susan Hawkins } \\
615-691-4877\end{array}$ \\
\hline $\begin{array}{l}\text { CyroDynamics, } \\
\text { Inc." }\end{array}$ & $\mathrm{CO}_{2}$ blasting & $\begin{array}{l}\text { Chris Wetherall } \\
615-376-4183\end{array}$ \\
\hline $\begin{array}{l}\text { Diversified } \\
\text { Environmental } \\
\text { Services } \\
\end{array}$ & $\mathrm{CO}_{2}$ blasting, chemical decontamination & $\begin{array}{l}\text { Dale Jessup } \\
615-482-8933\end{array}$ \\
\hline $\begin{array}{l}\text { Doolan } \\
\text { Environmental } \\
\end{array}$ & Microwave, scarification. blasting & $\begin{array}{l}\text { Dominick Guinto, Bruce Sutter } \\
609-988-8100\end{array}$ \\
\hline EET, Inc." & $\begin{array}{l}\text { TechXtract }{ }^{\mathrm{TM}} \text { chemical extract process } \\
\text { (demonstration at Hanford with Ivan Morgan) }\end{array}$ & $\begin{array}{l}\text { Mike Bonem } \\
713-662-0727\end{array}$ \\
\hline $\begin{array}{l}\text { Environmental } \\
\text { Alternatives, Inc. }\end{array}$ & $\begin{array}{l}\mathrm{CO}_{2} \text { blasting. AIM cellulose material blasting, } \\
\text { microwave }\end{array}$ & $\begin{array}{l}\text { Randy Martin } \\
603-357-8814 \\
\end{array}$ \\
\hline F2 Associates & Laser ablation & $\begin{array}{l}\text { Joyce Frelwald } \\
505-271-0260\end{array}$ \\
\hline Isotron ${ }^{n}$ & Electrochemical extraction & $\begin{array}{l}\text { Henry Lomasney, Richard Graves } \\
\text { 504-254-4624 }\end{array}$ \\
\hline Mele Associates ${ }^{2}$ & Chemical decontamination & $\begin{array}{l}\text { Mel and Elenor Chiogioji } \\
301-309-8442\end{array}$ \\
\hline
\end{tabular}




\section{3-22}

Table 3.2. (continued)

\begin{tabular}{|c|c|c|}
\hline Company & Technology and comments & Contact \\
\hline $\begin{array}{l}\text { Non-Destructive } \\
\text { Cleaning }\end{array}$ & $\mathrm{CO}_{2}$ blasting & $\begin{array}{l}\text { Patrick Gillis } \\
508-660-3064\end{array}$ \\
\hline $\begin{array}{l}\text { OBG Technical } \\
\text { Services }^{2}\end{array}$ & $\begin{array}{l}\text { Soda }\left(\mathrm{NaHCO}_{3} \text { ) blasting (demonstration at }\right. \\
\mathrm{K}-25 \text { ) }\end{array}$ & $\begin{array}{l}\text { Eric Newbauer } \\
315-437-6400\end{array}$ \\
\hline Pentek $^{2}$ & Scarification, wall walker & $\begin{array}{l}\text { Eric Crivella } \\
412-262-0725 \\
\end{array}$ \\
\hline $\begin{array}{l}\text { Quest Integrated, } \\
\text { Inc. }^{2}\end{array}$ & Scarification & $\begin{array}{l}\text { Dave Monserud, Bruce Goldwater } \\
206-872-9500\end{array}$ \\
\hline $\mathrm{SEG}^{2}$ & Sand blasting, $\mathrm{CO}^{2}$ blasting & $\begin{array}{l}\text { Don Barbour, Jerry Sharp } \\
615-220-1431\end{array}$ \\
\hline $\begin{array}{l}\text { Textron Defense } \\
\text { Systems }\end{array}$ & Electrohydraulic scabbling & $\begin{array}{l}\text { Dick Gannon } \\
617-381-4630\end{array}$ \\
\hline
\end{tabular}

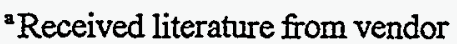


Table 3.3. Emerging candidate technologies for concrete decontamination

\begin{tabular}{|c|c|}
\hline Technology & Description \\
\hline \multicolumn{2}{|l|}{ Biological } \\
\hline $\begin{array}{l}\text { Biological decontamination (microbial- } \\
\text { influenced degradation) }\end{array}$ & $\begin{array}{l}\text { Microorganisms used to dissolve or disintegrate the concrete } \\
\text { matrix. Organisms are applied to the surface, and conditions } \\
\text { such as nutrients, temperature, and relative humidity are } \\
\text { maintained. The biomass etches the concrete surface, } \\
\text { removing the contaminants. After terminating organism } \\
\text { growth, the remaining biomass is removed by brushing or } \\
\text { vacuuming. }\end{array}$ \\
\hline \multicolumn{2}{|l|}{ Chemical } \\
\hline Chemical gels & $\begin{array}{l}\text { Uses a gel as a carrier of chemical decontamination agents. } \\
\text { The gel is applied to the surface and then scrubbed, wiped, } \\
\text { rinsed, or peeled off. Several applications may be required. }\end{array}$ \\
\hline $\begin{array}{l}\text { Decontamination and recycle of } \\
\text { concrete }\end{array}$ & $\begin{array}{l}\text { Decontamination of concrete by foam cleaning agents, low- } \\
\text { and high-pressure surface rinsing, and surface concrete } \\
\text { removal using high-pressure water. The waste is then } \\
\text { separated by using screens and microfiltration for fines } \\
\text { removal and using activated carbon for organic compound } \\
\text { removal. }\end{array}$ \\
\hline Electro-hydraulic scabbling & $\begin{array}{l}\text { Scabbling of concrete based on the generation of hydraulic } \\
\text { shock waves by means of an electric discharge. Process } \\
\text { minimizes secondary waste generation. }\end{array}$ \\
\hline $\begin{array}{l}\text { Electrokinetics (electromigration and } \\
\text { electroosmosis) }\end{array}$ & $\begin{array}{l}\text { Removes contaminants using an electric potential to cause ion } \\
\text { migration from the pores of the concrete into an electrolytic } \\
\text { solution that is subsequently treated. }\end{array}$ \\
\hline Solvent washing & $\begin{array}{l}\text { Based on washing contaminated items in solvent, with an } \\
\text { automated system to spray and recover the solvent. It is a } \\
\text { waste reduction and separation process in which radionuclides } \\
\text { are extracted from the media (e.g., soil, concrete) by use of } \\
\text { solvents. }\end{array}$ \\
\hline Strippable foil & $\begin{array}{l}\text { Removal of contaminants through chemical interactions of the } \\
\text { foil applied to the surface. The dried coating (foil) is then } \\
\text { removed. }\end{array}$ \\
\hline \multicolumn{2}{|l|}{ Mechanical } \\
\hline Centrifugal cryogenic $\mathrm{CO}_{2}$ blasting & $\begin{array}{l}\text { Uses high-speed, rotating wheel to accelerate } \mathrm{CO}_{2} \text { pellets and } \\
\text { is more efficient than compressed air. Pellets evaporate to } \\
\text { gaseous } \mathrm{CO}_{2} \text { upon impact, minimizing secondary waste. }\end{array}$ \\
\hline
\end{tabular}


Table 3.3. (continued)

\begin{tabular}{|c|c|}
\hline Technology & Description \\
\hline Compressed-air cryogenic $\mathrm{CO}_{2}$ blasting & $\begin{array}{l}\text { Similar to traditional sand blasting except that pellets are made } \\
\text { of solid } \mathrm{CO}_{2} \text { (dry ice). The dry ice pellets evaporate on } \\
\text { contact with the contaminated surface, minimizing secondary } \\
\text { waste. }\end{array}$ \\
\hline Concrete milling & $\begin{array}{l}\text { Shaves away the top layer of the concrete. Large milling } \\
\text { vehicles have been used commercially for paving and } \\
\text { potentially may apply to concrete floors. }\end{array}$ \\
\hline $\begin{array}{l}\text { Remotely operated dry ice pellet } \\
\text { decontamination system }\end{array}$ & $\begin{array}{l}\text { Decontamination of concrete by dry ice }\left(\mathrm{CO}_{2}\right) \text { blasting linked } \\
\text { with a remotely operated vehicle to reduce worker exposure } \\
\text { and costs. Remote operations are covered under a separate } \\
\text { focus area and, therefore, are not discussed further in this } \\
\text { report. }\end{array}$ \\
\hline Supercritical $\mathrm{CO}_{2}$ blasting & $\begin{array}{l}\text { Uses supercritical } \mathrm{CO}_{2}\left(>87.8^{\circ} \mathrm{F}\right) \text { pressurized up to } \\
55,000 \text { psi to generate high velocity } \mathrm{CO}_{2} \text { jets at speeds up to } \\
3,000 \mathrm{ft} / \mathrm{s} \text {. The jets remove surface contaminants without } \\
\text { damaging the clean substrate. }\end{array}$ \\
\hline \multicolumn{2}{|l|}{ Thermal } \\
\hline Dry heat roasting & $\begin{array}{l}\text { Currently at the problem definition stage. The technology is } \\
\text { simple in concept, well developed, and accepted by industry. } \\
\text { Its application in surface decontamination has not been } \\
\text { demonstrated. }\end{array}$ \\
\hline Flashlamp cleaning & $\begin{array}{l}\text { Uses energy absorbed from a high-energy xenon flashlamp to } \\
\text { cause rapid temperature rises, creating decomposition or } \\
\text { evaporation of material to a particulate residue. }\end{array}$ \\
\hline Laser etching and ablating & $\begin{array}{l}\text { Uses energy from pulsed laser beams to create a combination } \\
\text { of photochemical and photothermal effects beneath the } \\
\text { surface, causing thin layers of material to be ejected from the } \\
\text { surface. }\end{array}$ \\
\hline Laser heating & $\begin{array}{l}\text { Energy from a continuous-wave or pulsed laser is absorbed at } \\
\text { the surface, and the rapid temperature rise causes material to } \\
\text { evaporate or decompose to a carbonaceous reside. }\end{array}$ \\
\hline Microwave scabbling & $\begin{array}{l}\text { Microwave energy heats the free water present in the concrete } \\
\text { matrix, producing thermal and steam-pressure-induced } \\
\text { mechanical stresses that cause the concrete surface to burst. } \\
\text { The loosened particles may then be collected by a vacuum } \\
\text { system. }\end{array}$ \\
\hline
\end{tabular}


Table 3.3. (continued)

\begin{tabular}{ll}
\hline Technology & Description \\
\hline Plasma torch & $\begin{array}{l}\text { Uses an inert gas passing through a high-power arc discharge } \\
\text { to produce a very high temperature gas stream that is capable } \\
\text { of melting nearly all uncooled material. Potential use for rapid } \\
\text { spalling of concrete. }\end{array}$ \\
\hline
\end{tabular}

Sources: ORNL 1993; Oak Ridge K-25 Site 1993; INEL 1993, 1994; U.S. DOE 1993 b 
Table 3.4. Commercially available candidate technologies for concrete decontamination

\begin{tabular}{|c|c|}
\hline Technology & Description \\
\hline \multicolumn{2}{|l|}{ Chemical } \\
\hline Chelation treatment & $\begin{array}{l}\text { Removal of organic and inorganic compounds by } \\
\text { chemical dissolution with organic chelating agents. } \\
\text { Differs from solvent extraction in that an acid } \\
\text { solution is not required. }\end{array}$ \\
\hline Chemical foams $^{a}$ & $\begin{array}{l}\text { Foams used to carry off surface contaminants. } \\
\text { Consistent application and resident time is essential. }\end{array}$ \\
\hline Detergent (caustic) treatment & $\begin{array}{l}\text { Uses sequestering agents and detergents for surface } \\
\text { washing to remove particulates. Process applies to } \\
\text { surface-smearable contaminants. }\end{array}$ \\
\hline Strippable coatings ${ }^{a}$ & $\begin{array}{l}\text { Water-based organic polymer coatings applied by } \\
\text { spraying, brushing, or rolling and manually removed } \\
\text { once they have dried. Non-airborne secondary waste } \\
\text { is produced. }\end{array}$ \\
\hline \multicolumn{2}{|l|}{ Mechanical } \\
\hline $\mathrm{CO}_{2}$ blasting & $\begin{array}{l}\text { Concrete surfaces cleaned by blasting } \mathrm{CO}_{2} \text { ice } \\
\text { crystals under compressed air pressure. }\end{array}$ \\
\hline Chipping hammer & Used to decontaminate small inaccessible areas. \\
\hline Explosives ${ }^{a}$ & $\begin{array}{l}\text { Carefully placed and timed explosive charges remove } \\
\text { the top } 3 \text { to } 4 \text { in. of concrete. }\end{array}$ \\
\hline Grit blasting & $\begin{array}{l}\text { Pneumatic cleaning process commonly known as } \\
\text { sand blasting. Typical abrasives used are sand, glass } \\
\text { beads, metallic beads, and soft materials. A consi- } \\
\text { derable amount of secondary waste is produced. }\end{array}$ \\
\hline Hand brushing & $\begin{array}{l}\text { A labor-intensive process that removes loose } \\
\text { contaminants. Used primarily for pretreatment. }\end{array}$ \\
\hline Hand grinding, honing, scraping & $\begin{array}{l}\text { Hand-held, power-driven grinding equipment to } \\
\text { remove the surface of a contaminated object. }\end{array}$ \\
\hline High-pressure water & $\begin{array}{l}\text { Blasting surfaces with } 5,000 \text { to } 20,000 \text { psi water } \\
\text { pressure. Recontamination due to splashing is a } \\
\text { major drawback. }\end{array}$ \\
\hline Ice blasting $^{a}$ & $\begin{array}{l}\text { Shoots high-velocity ice particles at contaminated } \\
\text { surfaces. The contaminated waste water generated } \\
\text { by the melting ice particles is the controlling medium } \\
\text { for the displaced contamination. Decontamination } \\
\text { efficiency varies greatly. }\end{array}$ \\
\hline Multi-unit scarification & $\begin{array}{l}\text { Integration of scabbler, vacuum, and needle gun to } \\
\text { decontaminate cracks. Airbome contaminants are } \\
\text { minimized. }\end{array}$ \\
\hline Plastic pellet blasting & $\begin{array}{l}\text { A shot-blasting technique using plastic pellets as the } \\
\text { non-abrasive medium to decontaminate the surface. } \\
\text { Easy to recycle or dispose of by incineration. }\end{array}$ \\
\hline
\end{tabular}


Table 3.4. (continued)

\begin{tabular}{|c|c|}
\hline Technology & Description \\
\hline Scarification & $\begin{array}{l}\text { Reciprocating tungsten carbide bits scabble } \\
\text { contaminated concrete ( } 1 / 16 \text { to } 3 / 16 \text { in. per pass). } \\
\text { System driven by compressed air. }\end{array}$ \\
\hline Scabblers/scarifiers & $\begin{array}{l}\text { Mechanical impact methods to remove contaminated } \\
\text { surfaces. Usually high-speed, reciprocating, tung- } \\
\text { sten carbide-tipped pistons that are manually } \\
\text { operated. }\end{array}$ \\
\hline Shot blasting & $\begin{array}{l}\text { Steel shot blast able to remove } 1 / 4 \text { in of contami- } \\
\text { nated concrete per pass. Steel shots are recycled. }\end{array}$ \\
\hline Soft fiber medium blasting & $\begin{array}{l}\text { Blasting of compressed air and soft fiber in order to } \\
\text { remove up to } 1 / 8 \text { in. of concrete. Two grades of } \\
\text { fibers are available. }\end{array}$ \\
\hline Sponge blasting ${ }^{a}$ & $\begin{array}{l}\text { Blasting surface with air at } 110 \text { psig and patented } \\
\text { water-based urethane foam cleaning medium. } \\
\text { Aggressive medium removes the surface; non- } \\
\text { aggressive medium removes only surface } \\
\text { contaminants. }\end{array}$ \\
\hline Steam cleaning & $\begin{array}{l}\text { Combines solvent action of water (at high } \\
\text { temperatures) with the energy effect of blasting. }\end{array}$ \\
\hline Superheated water ${ }^{a}$ & $\begin{array}{l}\text { High-velocity water applied to the surface at } \\
300 \text { psi and at } 300^{\circ} \mathrm{F} \text {. Will remove only surface } \\
\text { contamination that is loosely bound or soluble. }\end{array}$ \\
\hline Ultrahigh-pressure water $^{a}$ & $\begin{array}{l}\text { Water applied to surfaces at speeds of } 3000 \mathrm{ft} / \mathrm{s} \text { and } \\
\text { pressure of } 55,000 \text { psi to remove all surface } \\
\text { contamination. Surface abrasion is possible. }\end{array}$ \\
\hline Vacuum cleaning & $\begin{array}{l}\text { Used primarily as a pre- and/or post-treatment } \\
\text { process. Loose solids are collected by a vacuum } \\
\text { system. }\end{array}$ \\
\hline Water flushing & $\begin{array}{l}\text { Low-pressure, hot or cold water is used to flush } \\
\text { loosely deposited contaminants. Used mainly as a } \\
\text { pretreatment process. }\end{array}$ \\
\hline \multicolumn{2}{|l|}{ Thermal } \\
\hline Flame Scarfing ${ }^{2}$ & $\begin{array}{l}\text { Heats concrete to cause differential expansion } \\
\text { (temperature gradient) and thus induce spalling of } \\
\text { contaminated area. }\end{array}$ \\
\hline
\end{tabular}

- Technology has been commercially accepted but has not been optimized. Sources: ORNL 1993, Oak Ridge K-25 Site 1993; INEL 1993, 1994; U.S. DOE 1993a. 
Table 3.5. Summary of candidate technologies for concrete decontamination

\begin{tabular}{|c|c|c|c|c|c|c|c|}
\hline Technology & $\begin{array}{l}\text { Stage of } \\
\text { development }\end{array}$ & Processing rates & $\begin{array}{l}\text { Secondary waste } \\
\text { generation }\end{array}$ & $\begin{array}{l}\text { Estimated } \\
\text { cost per } \mathrm{ft}^{2}\end{array}$ & $\begin{array}{l}\text { Removal } \\
\text { efficiency }\end{array}$ & Limiting conditions & Comments \\
\hline $\begin{array}{l}\text { Automated } \\
\text { brushing }\end{array}$ & Demonstration & Unknown & $\begin{array}{l}\text { Variable, HEPA filters } \\
\text { and brushing }\end{array}$ & $\$ 300.00$ & Unknown & $\begin{array}{l}\text { Not effective in } \\
\text { decontamination of } \\
\text { fixed contaminants }\end{array}$ & $\begin{array}{l}\text { HEPA filtering system is } \\
\text { integrated into this } \\
\text { technology }\end{array}$ \\
\hline $\begin{array}{l}\text { Automated } \\
\text { grinding }\end{array}$ & Conceptual & $15 \mathrm{ft}^{2} / \mathrm{min}$ & $\begin{array}{l}\text { Surface layer plus } \\
\text { grinding media }\end{array}$ & Unknown & Unknown & $\begin{array}{l}\text { Development of } \\
\text { vacuum system }\end{array}$ & $\begin{array}{l}\text { Effective for surface } \\
\text { contaminants only }\end{array}$ \\
\hline $\begin{array}{l}\text { Biological } \\
\text { (microbial } \\
\text { influenced } \\
\text { degeneration) }\end{array}$ & $\begin{array}{l}\text { Experimental/ } \\
\text { developmental }\end{array}$ & $4.7 \mathrm{~mm} /$ year & $\begin{array}{l}\text { Approximately half } \\
\text { the wastc produced by } \\
\text { conventional } \\
\text { technologies }\end{array}$ & $\$ 1.00-3.00$ & Unknown & Nutrient availability & $\begin{array}{l}\text { Reduced risks compared } \\
\text { to conventional } \\
\text { technologies; passive } \\
\text { process }\end{array}$ \\
\hline $\begin{array}{l}\text { Detergent } \\
\text { (caustic) } \\
\text { treatment }\end{array}$ & Commercial & Unknown & Caustic solutions & $>\$ 1.00$ & Variable & Labor-intensive & $\begin{array}{l}\text { Surface decontamination } \\
\text { only; used extensively at } \\
\text { gaseous diffusion plants }\end{array}$ \\
\hline $\begin{array}{l}\text { Centrifugal } \\
\text { cryogenic } \\
\text { blasting } \mathrm{CO}_{2}\end{array}$ & Developmental & $0.50-1.5 \mathrm{ft}^{2} / \mathrm{min}$ & Variable & $\$ 0.90-26.00$ & Unknown & $\begin{array}{l}\text { Surface } \\
\text { decontamination } \\
\text { only; waste handling } \\
\text { of contaminated } \\
\text { water }\end{array}$ & $\begin{array}{l}\text { Current system is not } \\
\text { suited for rad } \\
\text { decontamination; has } \\
\text { been demonstrated at } \\
\text { several sites; robotics } \\
\text { and water reuse/recycling } \\
\text { system is needed; used } \\
\text { commercially to } \\
\text { decontaminate hand tools }\end{array}$ \\
\hline Chelation & Demonstration & Variable & $\begin{array}{l}\text { Waste stream must be } \\
\text { oxidized }\end{array}$ & $\$ 1.00$ & Excellent & $\begin{array}{l}\text { Selection of } \\
\text { chelating agents }\end{array}$ & Easy to apply \\
\hline $\begin{array}{l}\text { Chemical } \\
\text { extraction }\end{array}$ & Demonstration & $100 \mathrm{ft}^{2} / \mathrm{h}$ & $0.03-0.06 \mathrm{gal} / \mathrm{ft}^{2}$ & $\$ 4.00-50.00$ & Up to $99 \%$ & $\begin{array}{l}\text { Depth of } \\
\text { contaminants }\end{array}$ & $\begin{array}{l}\text { Several demonstrations } \\
\text { have been conducted with } \\
\text { mixed results }\end{array}$ \\
\hline Chemical foams & Commercial & Variable & $\begin{array}{l}\text { Rinse water and } \\
\text { residuals }\end{array}$ & $\$ 0.50-2.00$ & $75-90 \%$ & $\begin{array}{l}\text { Ineffective with } \\
\text { cracked or } \\
\text { convoluted surfaces }\end{array}$ & $\begin{array}{l}\text { Primarily used as a } \\
\text { pretreatment }\end{array}$ \\
\hline Chemical gels & Demonstration & Unknown & $\begin{array}{l}\text { Rinse water and } \\
\text { residuals }\end{array}$ & $\$ 0.50-2.00$ & Up to $100 \%$ & $\begin{array}{l}\text { Complex chemical } \\
\text { system }\end{array}$ & $\begin{array}{l}\text { Costly and time } \\
\text { consuming }\end{array}$ \\
\hline $\begin{array}{l}\text { Chipping } \\
\text { hammer/paving } \\
\text { breaker }\end{array}$ & Commercial & $\begin{array}{l}20 \mathrm{yd}^{3} / \mathrm{day}(90-\mathrm{lb} \\
\text { hammer) }\end{array}$ & Variable & Variable & Variable & $\begin{array}{l}\text { Leaves surface very } \\
\text { rough; large amount } \\
\text { of dust produced }\end{array}$ & $\begin{array}{l}\text { Used to decontaminate } \\
\text { small inaccessible areas; } \\
\text { primarily used in } \\
\text { demolition activity; can } \\
\text { be used to decon surfaces }\end{array}$ \\
\hline
\end{tabular}


Table 3.5. (continued)

\begin{tabular}{|c|c|c|c|c|c|c|c|}
\hline Technology & $\begin{array}{l}\text { Stage of } \\
\text { development }\end{array}$ & Processing rates & $\begin{array}{l}\text { Secondary waste } \\
\text { generation }\end{array}$ & $\begin{array}{l}\text { Estimated } \\
\text { cost per } \mathrm{ft}^{2}\end{array}$ & $\begin{array}{l}\text { Removal } \\
\text { efficiency }\end{array}$ & Limiting conditions & Comments \\
\hline Concrete milling & Conceptual & Unknown & $\begin{array}{l}\text { Top } 6-25 \mathrm{~mm} \text { of } \\
\text { concrete removed }\end{array}$ & $\$ 0.75$ & Unknown & $\begin{array}{l}\text { Suited for horizontal } \\
\text { surfaces only }\end{array}$ & $\begin{array}{l}\text { Equipment is available } \\
\text { but has not been used for } \\
\text { decontamination } \\
\text { purposes }\end{array}$ \\
\hline $\begin{array}{l}\text { Compressed-air } \\
\text { cryogenic } \\
\text { blasting } \mathrm{CO}_{2}\end{array}$ & Demonstration & $0.50-1.5 \mathrm{ft}^{2} / \mathrm{min}$ & Variable & $\$ 8.00-26.00$ & Unknown & $\begin{array}{l}\text { Surface } \\
\text { decontamination } \\
\text { only; waste handling } \\
\text { of contaminated } \\
\text { water }\end{array}$ & $\begin{array}{l}\text { Robotics and water } \\
\text { reuse/recycling system is } \\
\text { needed }\end{array}$ \\
\hline $\mathrm{CO}_{2}$ blasting & Commercial & $10-90 \mathrm{ft}^{2} / \mathrm{hr}$ & Variable & $\$ 0.90-1.75$ & $\begin{array}{l}\text { Surface } \\
\text { contaminants }\end{array}$ & $\begin{array}{l}\mathrm{CO}_{2} \text { in confined area; } \\
\text { depth of } \\
\text { contamination }\end{array}$ & $\begin{array}{l}\mathrm{CO}_{2} \text { vaporizes, reducing } \\
\text { secondary waste }\end{array}$ \\
\hline $\begin{array}{l}\text { Electro-hydraulic } \\
\text { scabbling }\end{array}$ & Developmental & $20-40 \mathrm{ft}^{2} / \mathrm{h}$ & $\begin{array}{l}0.5-1 \mathrm{gal} / \mathrm{ft}^{2} \text { (liquid- } \\
\text { solid mixture) }\end{array}$ & $\$ 0.65-1.85$ & $\begin{array}{l}100 \% \text { up to } 1 \text { in. } \\
\text { deep }\end{array}$ & $\begin{array}{l}\text { Currently applicable } \\
\text { to floors only }\end{array}$ & $\begin{array}{l}\text { Initial design for floors } \\
\text { only; removes } \sim 1 \text { in. of } \\
\text { surface concrete per pass; } \\
\text { airborne particulates are } \\
\text { minimal }\end{array}$ \\
\hline Electrokinetic & Developmental & $\begin{array}{l}\text { Not yet } \\
\text { determined }\end{array}$ & $\begin{array}{l}\text { Liquid used during } \\
\text { process; volume not } \\
\text { yet determined }\end{array}$ & $\begin{array}{l}\text { Not yet } \\
\text { determined }\end{array}$ & $65->90 \%$ & $\begin{array}{l}\text { Currently applicable } \\
\text { to floors only }\end{array}$ & $\begin{array}{l}\text { Developmental/ } \\
\text { optimization stage }\end{array}$ \\
\hline Explosives & Commercial & Variable & $\sim 0.25 \mathrm{ft}^{3} / \mathrm{ft}^{2}$ & $\$ 50.00$ & Up to $100 \%$ & Dust containment & $\begin{array}{l}\text { Top } 3 \text { to } 4 \text { in. of concrete } \\
\text { are removed per } \\
\text { detonation }\end{array}$ \\
\hline Flame scarfing & Commercial & Unknown & Unknown & Unknown & Unknown & $\begin{array}{l}\text { Produces radioactive } \\
\text { airborne particulates }\end{array}$ & $\begin{array}{l}\text { Concrete is heated to } \\
\text { cause differential } \\
\text { expansion and spalling }\end{array}$ \\
\hline $\begin{array}{l}\text { Flashlamp } \\
\text { cleaning }\end{array}$ & Demonstration & Up to $120 \mathrm{ft}^{2} / \mathrm{h}$ & Ash from coating & $\$ 4.50-25.00$ & Unknown & $\begin{array}{l}\text { Surface decontami- } \\
\text { nation only }\end{array}$ & $\begin{array}{l}\text { Input from xenon } \\
\text { vendors is critical }\end{array}$ \\
\hline $\begin{array}{l}\text { Grit blasting } \\
\text { (sand blasting) }\end{array}$ & Commercial & $\begin{array}{l}\sim 47 \mathrm{ft}^{2} / \mathrm{h} \\
\text { Dependent on grit } \\
\text { used }\end{array}$ & $0.03 \mathrm{ft}^{3} / \mathrm{ft}^{2}$ (solids) & $\sim \$ 5.00-10.00$ & Up to $100 \%$ & $\begin{array}{l}\text { Waste-processing } \\
\text { system }\end{array}$ & $\begin{array}{l}\text { Waste production rates } \\
\text { depend on media/surface } \\
\text { combinations }\end{array}$ \\
\hline Hand brushing & Commercial & Variable & $\sim 0.003 \mathrm{ft}^{3} / \mathrm{ft}^{2}$ & Up to $\$ 82$ & Variable & Labor-intensive & Cost includes labor \\
\hline $\begin{array}{l}\text { Hand grinding, } \\
\text { honing, scraping }\end{array}$ & Commercial & Variable & Variable & $\$ 0.50-1.00$ & Variable & $\begin{array}{l}\text { Limited to } \\
\text { decontamination of } \\
\text { small areas }\end{array}$ & $\begin{array}{l}\text { Remote operation will } \\
\text { improve efficiency }\end{array}$ \\
\hline
\end{tabular}


Table 3.5. (continued)

\begin{tabular}{|c|c|c|c|c|c|c|c|}
\hline Technology & $\begin{array}{l}\text { Stage of } \\
\text { development }\end{array}$ & Processing rates & $\begin{array}{l}\text { Secondary waste } \\
\text { generation }\end{array}$ & $\begin{array}{l}\text { Estimated } \\
\text { cost per } \mathrm{ft}^{2}\end{array}$ & $\begin{array}{l}\text { Removal } \\
\text { efficiency }\end{array}$ & Limiting conditions & Comments \\
\hline $\begin{array}{l}\text { High-pressure } \\
\text { water }\end{array}$ & Commercial & $\sim 370 \mathrm{ft}^{2} / \mathrm{h}$ & $\begin{array}{l}0.03 \mathrm{ft}^{3} / \mathrm{ft}^{2}, 4-100 \\
\text { gpm liquids }\end{array}$ & $\$ 0.06-2.00$ & Variable & $\begin{array}{l}\text { Uses large amounts } \\
\text { of water }\end{array}$ & $\begin{array}{l}\text { Water reuse/recycling } \\
\text { system is needed }\end{array}$ \\
\hline Ice blasting & Commercial & $\begin{array}{l}\text { Similar to other } \\
\text { blasting } \\
\text { technologies }\end{array}$ & $\begin{array}{l}\sim 15 \text { gal } / \mathrm{h} \text { waste-water } \\
\text { generation rate }\end{array}$ & $\$ 1.00$ & Unknown & $\begin{array}{l}\text { Limited to surface } \\
\text { decontamination }\end{array}$ & $\begin{array}{l}\text { Remote operation will } \\
\text { improve efficiency }\end{array}$ \\
\hline Laser ablation & Developmental & $85 \mathrm{ft}^{2} / \mathrm{h}$ & $\begin{array}{l}75 \% \text { waste reduction is } \\
\text { projected }\end{array}$ & $\sim \$ 1.00$ & Unknown & None identified & $\begin{array}{l}\text { Currently building a full- } \\
\text { scale prototype }\end{array}$ \\
\hline Laser heating & Developmental & $2.5 \mathrm{ft}^{2} / \mathrm{min}$ & Unknown & $\$ 1.00$ & Unknown & $\begin{array}{l}\text { Currently used to } \\
\text { decontaminate } \\
\text { metallic surfaces }\end{array}$ & $\begin{array}{l}\text { Decontamination of large } \\
\text { surface areas with } \\
\text { minimum amount of } \\
\text { waste generation }\end{array}$ \\
\hline $\begin{array}{l}\text { Microwave } \\
\text { scabbling }\end{array}$ & Demonstration & $40 \mathrm{ft}^{2} / \mathrm{h}$ & $0.15 \mathrm{ft}^{3} / \mathrm{ft}^{2}$ solids & $\sim \$ 2.00$ & $\begin{array}{l}100 \% \\
2 \text { in. per pass }\end{array}$ & $\begin{array}{l}\text { Removes top layer of } \\
\text { concrete }\end{array}$ & $\begin{array}{l}\text { Technique has not been } \\
\text { optimized. Not available } \\
\text { in the private sector }\end{array}$ \\
\hline $\begin{array}{l}\text { Multi-unit } \\
\text { scarification }\end{array}$ & Commercial & $20-300 \mathrm{ft}^{2} / \mathrm{h}$ & $\begin{array}{l}0.078 \mathrm{gal} / \mathrm{ft}^{2} \text { solids at } \\
1 / 16 \text {-in. removal; } \\
\text { needle gun only } 0.03 \\
\text { gal } / \mathrm{ft}^{2}\end{array}$ & $\$ 1.85-2.50$ & $1 / 16$ in. per pass & Noise pollution & $\begin{array}{l}\text { Integration of several } \\
\text { pieces of scabbling } \\
\text { equipment }\end{array}$ \\
\hline Plasma torch & Developmental & Unknown & & $\sim \$ 1.00$ & Unknown & Spalling of concrete & $\begin{array}{l}\text { Technology currently } \\
\text { used to decontaminate } \\
\text { hazardous surfaces }\end{array}$ \\
\hline $\begin{array}{l}\text { Plastic pellet } \\
\text { blasting }\end{array}$ & Commercial & $4 \mathrm{ft}^{2} / \mathrm{min}$ & $\begin{array}{l}\text { Similar to other } \\
\text { scabbling/blasting } \\
\text { processes }\end{array}$ & $\$ 0.20-2.15$ & Unknown & $\begin{array}{l}\text { Demonstration of } \\
\text { specific medium } \\
\text { needed }\end{array}$ & $\begin{array}{l}\text { Pellets need to be } \\
\text { optimized; widely used as } \\
\text { an alternative to grit } \\
\text { blasting }\end{array}$ \\
\hline Scarification & Commercial & $200-400 \mathrm{ft}^{2} / \mathrm{h}$ & $\begin{array}{l}0.078 \mathrm{gal} / \mathrm{ft}^{2} \text { at } 1 / 16- \\
\text { in. removal }\end{array}$ & $\$ 1.85-2.50$ & $1 / 16$ in. per pass & Noise pollution & $\begin{array}{l}\text { Collects } 99.5 \% \text { of all } \\
\text { debris }\end{array}$ \\
\hline Shot blasting & Commercial & $30-3000 \mathrm{ft}^{2} / \mathrm{h}$ & Variable & $\$ 0.04-5.02$ & $10-100 \%$ & $\begin{array}{l}\text { Airborne debris; } \\
\text { system for } \\
\text { processing waste } \\
\text { needed }\end{array}$ & $\begin{array}{l}\text { Conventional } \\
\text { decontamination } \\
\text { equipment; removes } \\
\sim 1 / 4 \text { in. of concrete per } \\
\text { pass }\end{array}$ \\
\hline
\end{tabular}


Table 3.5. (continued)

\begin{tabular}{|c|c|c|c|c|c|c|c|}
\hline Technology & $\begin{array}{l}\text { Stage of } \\
\text { development }\end{array}$ & Processing rates & $\begin{array}{l}\text { Secondary waste } \\
\text { generation }\end{array}$ & $\begin{array}{l}\text { Estimated } \\
\text { cost per } \mathrm{ft}^{2}\end{array}$ & $\begin{array}{l}\text { Removal } \\
\text { efficiency }\end{array}$ & Limiting conditions & Comments \\
\hline $\begin{array}{l}\text { Soda blasting } \\
\left(\mathrm{NaHCO}_{3}\right)\end{array}$ & Demonstration & $120-240 \mathrm{ft}^{2} / \mathrm{h}$ & $\begin{array}{l}0.007 \mathrm{ft}^{3} / \mathrm{ft}^{2} \text { (solids) } \\
1.9 \mathrm{gal} / \mathrm{ft}^{2} \text { (liquid) }\end{array}$ & $\$ 5.00-7.00$ & $95-99 \%$ & $\begin{array}{l}\text { Multiple units } \\
\text { required for } \\
\text { secondary-waste } \\
\text { processing }\end{array}$ & $\begin{array}{l}\text { Commercially available } \\
\text { for non-rad cleanup }\end{array}$ \\
\hline $\begin{array}{l}\text { Soft media } \\
\text { blasting }\end{array}$ & Commercial & $60-100 \mathrm{ft}^{2} / \mathrm{h}$ & $\begin{array}{l}0.001-0.01 \mathrm{ft}^{3} / \mathrm{ft}^{2} \\
\text { (solids) }\end{array}$ & $\$ 10-12$ & $90-99 \%$ & $\begin{array}{l}\text { Uses large amounts } \\
\text { of water }\end{array}$ & $\begin{array}{l}\text { Successful in mixed waste } \\
\text { decontamination }\end{array}$ \\
\hline Solvent washing & Conceptual & Unknown & Unknown & Unknown & Unknown & $\begin{array}{l}\text { Applicable only to } \\
\text { smearable } \\
\text { contamination }\end{array}$ & $\begin{array}{l}\text { Limited to small areas of } \\
\text { contamination }\end{array}$ \\
\hline Steam cleaning & Commercial & Unknown & Condensed steam & $\$ 0.50-2.00$ & Variable & $\begin{array}{l}\text { Uses large amounts } \\
\text { of water }\end{array}$ & $\begin{array}{l}\text { Not effective for } \\
\text { removing fixed } \\
\text { contaminants }\end{array}$ \\
\hline $\begin{array}{l}\text { Strippable } \\
\text { coating }\end{array}$ & Commercial & Up to $100 \mathrm{ft}^{2} / \mathrm{h}$ & Coating residuals & $\$ 1.00-1.40$ & Variable & $\begin{array}{l}\text { Cost of strippable } \\
\text { coating }\end{array}$ & $\begin{array}{l}\text { Application and removal } \\
\text { times are long }\end{array}$ \\
\hline $\begin{array}{l}\text { Strippable } \\
\text { coating } \\
\text { (SensorCoat) }\end{array}$ & Developmental & Undetermined & Undetermined & Undetermined & Undetermined & $\begin{array}{l}\text { Depth of } \\
\text { contamination }\end{array}$ & $\begin{array}{l}\text { Proof of process has been } \\
\text { shown but development } \\
\text { is required }\end{array}$ \\
\hline $\begin{array}{l}\text { Supercritical } \mathrm{CO}_{2} \\
\text { blasting }\end{array}$ & Developmental & Unknown & $\begin{array}{l}\text { Variable, spent } \\
\text { grinding media }\end{array}$ & Unknown & Unknown & $\begin{array}{l}\text { Optimizing pressure } \\
\text { and speed of cleaning } \\
\text { head }\end{array}$ & $\begin{array}{l}\text { System optimization is } \\
\text { required for } \\
\text { commercialization }\end{array}$ \\
\hline Superheated water & Commercial & Variable & $0.4-2 \mathrm{gal} / \mathrm{min}$ liquids & $\$ 0.50-2.00$ & Variable & $\begin{array}{l}\text { Uses large amounts } \\
\text { of water }\end{array}$ & $\begin{array}{l}\text { Robotics and water } \\
\text { reuse/recycling system } \\
\text { are needed }\end{array}$ \\
\hline $\begin{array}{l}\text { Ultra-high- } \\
\text { pressure water }\end{array}$ & Commercial & $1 \mathrm{ft}^{2} / \mathrm{min}$ & $3-5 \mathrm{gal} / \mathrm{ft}^{2}$ liquid & $\sim \$ 2.00$ & Unknown & $\begin{array}{l}\text { Water recycling } \\
\text { system }\end{array}$ & $\begin{array}{l}\text { Robotics control is in } \\
\text { development; numerous } \\
\text { non-rad } \\
\text { decontaminations }\end{array}$ \\
\hline Vacuum cleaning & Commercial & $40-54 \mathrm{ft}^{2} / \mathrm{h}$ & $\begin{array}{l}\text { Dependent on depth of } \\
\text { removal }\end{array}$ & $\$ 2.00-11.00$ & Variable & $\begin{array}{l}\text { Limited to confined } \\
\text { areas }\end{array}$ & $\begin{array}{l}\text { This is a pre- and/or post- } \\
\text { treatment process; } \\
\text { surface decontamination }\end{array}$ \\
\hline Water flushing & Commercial & Variable & Variable & $\sim \$ 1.00$ & Variable & $\begin{array}{l}\text { Uses large amounts } \\
\text { of water }\end{array}$ & $\begin{array}{l}\text { Readily used to pre-treat } \\
\text { surfaccs }\end{array}$ \\
\hline
\end{tabular}

DOD: Department of Defense 
$3-32$

Table 3.6 Estimated costs for emerging concrete decontamination technologies

\begin{tabular}{|c|c|c|c|c|}
\hline Technology & $\begin{array}{c}\text { Estimated } \\
\text { Capital Cost, \$ }\end{array}$ & $\begin{array}{l}\text { Estimated } \\
\text { Operating } \\
\text { Cost, \$/ft }\end{array}$ & $\begin{array}{c}\text { Estimated } \\
\text { Labor Costs, } \\
\$ / h r\end{array}$ & Comment \\
\hline Automated brushing & $250 \mathrm{~K}$ & 300 & variable & \\
\hline Automated grinding & up to $500 \mathrm{~K}$ & unknown & variable & \\
\hline $\begin{array}{l}\text { Biological (microbial- } \\
\text { influenced degradation) }\end{array}$ & unavailable & 1 to 3 & $\begin{array}{l}\text { included in } \\
\text { operating cost }\end{array}$ & \\
\hline $\begin{array}{l}\text { Centrifugal cryogenic } \\
\mathrm{CO}_{2} \text { blasting }\end{array}$ & 100 to $200 \mathrm{~K}$ & 0.075 to 0.75 & unknown & $\begin{array}{l}\text { Technology may require up } \\
\text { to } \sim \$ 750 \mathrm{~K} \text { for concrete } \\
\text { application development. }\end{array}$ \\
\hline Chelation & unavailable & $<1$ & unknown & \\
\hline Chemical extraction & $<5 \mathrm{~K}$ & 4 to 5 & up to $43.75^{a}$ & $\begin{array}{l}\text { Assumes 2-person team for } \\
\text { application. }\end{array}$ \\
\hline Chemical foams & $<50 \mathrm{~K}$ & 0.5 to 2 & $43.75^{a}$ & $\begin{array}{l}\text { Assumes 2-person team for } \\
\text { application. }\end{array}$ \\
\hline Chemical gels & $<50 \mathrm{~K}$ & 0.5 to 2 & $43.75^{a}$ & $\begin{array}{l}\text { Assumes 12-person team for } \\
\text { application. }\end{array}$ \\
\hline $\begin{array}{l}\text { Chromographic } \\
\text { strippable coatings }\end{array}$ & unavailable & unavailable & unavailable & $\begin{array}{l}\text { Cost information is not } \\
\text { available due to the early } \\
\text { development stage of the } \\
\text { process. }\end{array}$ \\
\hline $\mathrm{CO}_{2}$ blasting & $300 \mathrm{~K}$ & 0.90 to 1.75 & $\begin{array}{l}15 \text { to } 300 \\
\text { (includes } \\
\text { operating cost) } \\
\end{array}$ & $\begin{array}{l}\text { Higher cost range estimates } \\
\text { are for application to } \\
\text { radioactive contaminants. }\end{array}$ \\
\hline $\begin{array}{l}\text { Compressed-air } \\
\text { cryogenic } \mathrm{CO}_{2} \text { pellet } \\
\text { blasting }\end{array}$ & unavailable & 8 to 26 & unknown & $\begin{array}{l}\text { Operating cost includes } \\
\text { energy requirements. }\end{array}$ \\
\hline Concrete milling & $11 \mathrm{~K}$ & 0.75 & $43.75^{a}$ & \\
\hline $\begin{array}{l}\text { Detergent (caustic) } \\
\text { treatment }\end{array}$ & $<10 \mathrm{~K}$ & $>1.00$ & variable & \\
\hline $\begin{array}{l}\text { Electro-hydraulic } \\
\text { scabbling }\end{array}$ & unavailable & 0.65 to 1.85 & $\begin{array}{l}\text { included in } \\
\text { operating cost }\end{array}$ & $\begin{array}{l}\text { Assumed that the process } \\
\text { would be provided as a } \\
\text { service by private industry. }\end{array}$ \\
\hline Electrokinetics & unavailable & unavailable & unavailable & $\begin{array}{l}\text { Cost information will be } \\
\text { available from the vendor by } \\
\text { mid-June. }\end{array}$ \\
\hline Explosives & $50 \mathrm{~K}$ & 50 & unknown & \\
\hline Flame scarifing & unavailable & unavailable & unavailable & \\
\hline Flashlamp & $500 \mathrm{~K}$ & 4.5 to 25 & $\begin{array}{l}\text { included in } \\
\text { operating cost }\end{array}$ & $\begin{array}{l}\text { Assumed that the process } \\
\text { would be provided as a } \\
\text { service by private industry. }\end{array}$ \\
\hline Grit (sand) blasting & unavailable & 5 to 10 & $43.75^{a}$ & \\
\hline $\begin{array}{l}\text { Hand grinding, honing, } \\
\text { scraping }\end{array}$ & unavailable & 0.5 to 1 & variable & \\
\hline High-pressure water & 50 to $75 \mathrm{~K}$ & 0.06 to 2 & $43.75^{a}$ & \\
\hline Ice blasting & 60 to $155 \mathrm{~K}$ & 1 & $43.75^{a}$ & \\
\hline Laser ablation & $\begin{array}{l}700 \mathrm{~K} \text { (up to } \\
1 \mathrm{M} \text { to develop } \\
\text { prototype) } \\
\end{array}$ & unavailable & unknown & $\begin{array}{l}\text { It is likely that the process } \\
\text { will be provided as a service } \\
\text { by private industry. }\end{array}$ \\
\hline Microwave & $150 \mathrm{~K}$ & 2 & $43.75^{a}$ & \\
\hline
\end{tabular}




\section{3-33}

Table 3.6. (continued)

\begin{tabular}{|c|c|c|c|c|}
\hline Technology & $\begin{array}{c}\text { Estimated } \\
\text { Capital Cost }\end{array}$ & $\begin{array}{l}\text { Estimated } \\
\text { Operating } \\
\text { Cost, \$/ft }\end{array}$ & $\begin{array}{c}\text { Estimated } \\
\text { Labor Costs, } \\
\$ / \mathrm{hr}\end{array}$ & Comment \\
\hline Plasma torch & $<100 \mathrm{~K}$ & 1 & $<100$ & \\
\hline Plastic pellet blasting & unavailable & 0.20 to 2.15 & 43 to 63 & \\
\hline Scarification & $110 \mathrm{~K}$ & 5 to 12.6 & $43.75^{a}$ & \\
\hline Shot blasting & $4 \mathrm{M}$ & 0.04 to 5.02 & $43.75^{a}$ & $\begin{array}{l}\text { Capital cost estimate is based } \\
\text { on the cost to design and } \\
\text { build a pilot facility. }\end{array}$ \\
\hline Soft media blasting & $20 \mathrm{~K}$ & 2,10 to 12 & $43.75^{a}$ & $\begin{array}{l}\text { Higher cost range includes } \\
\text { labor costs when assumed } \\
\text { the process is provided as a } \\
\text { service by private industry }\end{array}$ \\
\hline Soda blasting & unavailable & 5 to 7 & $43.75^{a}$ & $\begin{array}{l}\text { Operation cost estimated at } \\
\$ 5.62 / \mathrm{ft}^{2} \text { at } \mathrm{K}-25 \\
\text { demonstration. }\end{array}$ \\
\hline Steam cleaning & 50 to $75 \mathrm{~K}$ & 0.05 to 2 & $43.75^{a}$ & \\
\hline Strippable coatings & $<10 \mathrm{~K}$ & 1 to 1.4 & $43.75^{a}$ & $\begin{array}{l}\text { Assumes 2-person team for } \\
\text { application. Capital cost is } \\
\text { for the spraying unit. }\end{array}$ \\
\hline $\begin{array}{l}\text { Supercritical } \mathrm{CO}_{2} \\
\text { blasting }\end{array}$ & $150 \mathrm{~K}$ & 1 & $43.75^{a}$ & \\
\hline Superheated water & $175 \mathrm{~K}$ & 0.05 to 2 & $43.75^{a}$ & \\
\hline Ultrahigh-pressure water & $>500 \mathrm{~K}$ & $>2$ & $43.75^{a}$ & \\
\hline Water flushing & $<5 \mathrm{~K}$ & $<1$ & variable & \\
\hline
\end{tabular}

a labor cost estimate based on a 2-person team at $\$ 40 \mathrm{~K} /$ year/person.

Sources: INEL 1993, 1994; Oak Ridge K-25 Site 1993; ORNL 1993 


\section{Screening and Matching Problems with Emerging Technologies}

\subsection{Introduction}

After assimilating information on the contaminated concrete problem (nature and extent) and candidate technologies for decontamination, efforts to screen and match emerging technologies to concrete contamination problems began. Initially it was envisioned by the project team that the Kepner-Tregoe (Kepner and Tregoe 1973) screening and evaluation process would be used to provide a systematic approach for recommending technology demonstrations. However, early in this process several problems arose.

First, it was difficult to compare technologies based on some set of criteria when the technologies are at different stages of development. For example, technologies in early development stages might be removed from further consideration when compared to well-established and demonstrated technologies. This would imply that the most important criteria for a technology is the stage of development. Thus, potentially promising technologies with application to problems that are not adequately addressed by existing technologies (cracks and penetrations) might be eliminated. Second, much of the specific data required for screening, such as cost, processing rates, secondary waste generation, etc., is not well defined or known for technologies in the earlier stages of development. It is this type of data that is intended to be obtained from demonstrations. Third, because specific sites for conducting the demonstrations have not been identified, several of the evaluation criteria used in a more rigorous screening process could not be defined with certainty. For example, although there are broad considerations that can be taken into account for implementability, many aspects of the criteria are directly related to the site (contaminant concentration and depth, limiting conditions impacting equipment operation, site safety support, worker and environmental risk). Finally, it would have required more time than the schedule allowed to conduct a more rigorous screening process (such as Kepner-Tregoe). The project team recognized that a more rigorous screening process was appropriate and should be used when a technology is being selected for a specific application for cleanup (e.g., treatability demonstrations or decontamination'of a specific facility). However, the goals of the project were to identify and demonstrate promising technologies for application to a wide variety of concrete problems throughout the $\mathrm{DOE}$ complex.

\subsection{Methods}

A process for evaluating technologies based on the ability of an action (in this case a demonstration) to further the development of a technology toward implementation and technology transfer was used for technology screening (Paladino and Longsworth 1995). The technology development and implementation continuum is broken into several stages of development, 
each separated by a decision point (gate). A technology is evaluated based on a set of decision-point criteria that are appropriate for the technologies at various stages of development. If a demonstration of the technology meets these criteria (i.e., provides the information that is appropriate for the stage of development, see Fig. 4.1), the technology passes the gate and moves to the next stage of development. The process meets project goals by allowing review of technologies at different stages of development.

\subsection{Results and Discussion}

A team meeting held to conduct the screening process included representatives familiar with engineering, technology development, decontamination technologies, demonstration implementation, and health and safety. Based on the results of the first project task (see Sects. 2 and 3), concrete problems across the DOE complex were identified and categorized, emerging technologies with potential for addressing the problems were listed, and DOE sites with representative problems as potential demonstration sites were identified (Table 4.1).

For the purposes of this evaluation, contaminated concrete was broken into four different categories: (1) transferrable surface areas containing contamination on the concrete surface that is removable and is not within the concrete matrix; (2) fixed surface areas containing contaminants in the concrete matrix at a depth of $1 / 8$ in. or greater; (3) deep contamination containing contaminants that have migrated beyond the surface due to cracks and penetrations; and (4) bulk contamination, assumed to be activated concrete and, therefore, inappropriate for decontamination processes. The fixed surface area category was subdivided to take into account different conditions that impact decontamination, including bare floors, painted floors, bare walls, painted walls, and containments such as basins and pools. It was recognized by the team that hot cells could be considered separately. However, it was assumed that if decontamination did not require remotely operated technologies, which are not within the scope of this project, then decontamination of the hot cell could be conducted by considering a combination of the other fixed surface area subcategories.

Screening of candidate technologies focused on emerging technologies. Commercially available technologies (such as scabbling) were used as baseline technologies for comparison. The preliminary candidate technologies were screened based on factors such as time before the technology was expected to be ready for field application (ready for demonstration by FY 96) and the likelihood of implementation (regulatory and safety issues). Several technologies were removed from further consideration at this time. Next, the stage of development for each technology potentially applicable to a problem was identified, and the usefulness of a demonstration to move the technology through a "gate" and to the next stage of development was evaluated (Fig. 4.1 and Table 4.2). A relative rank (high, medium, low) was given to each technology within a problem area based on the probability of a demonstration moving the technology through a gate and providing new information for addressing the concrete 
problem. Other considerations given during ranking included previously conducted demonstrations, need for a technology to move to the next stage or be removed from the development process (i.e., technologies that have stalled out in the development process), and if a need is addressed that is not resolved by other technologies. For example, for surface areas with transferrable contamination, chemical extraction was ranked low because the technology is considered to be in the commercial stage and a demonstration of the technology for this problem would not move the development through a gate. However, for deep contamination in cracks and penetrations, chemical extraction was rated high because a demonstration for this problem may move the technology through a gate to implementation for a problem that is not adequately addressed by other technologies. A record of the comments and considerations during ranking of each technology was kept and is summarized in Table 4.2. The assumptions made during the evaluation were verified with vendors and technology developers to ensure that the team had an accurate understanding of the technology and its applicability to the problem.

The results from this screening process provided information regarding the breadth of problems covered by a specific technology (a measure of the fraction of concrete within the DOE complex that the technology has the potential to address) and a relative perspective on the value added to development of a technology if a demonstration were to be conducted. It should be noted that based on the uncertainties of the available data describing the extent of contamination (Sect. 2), it is not possible to accurately estimate the percentage of the total contaminated concrete represented by each specific problem area (e.g., $75 \%$ of the contaminated concrete within the DOE complex is associated with bare floors). However, general trends indicate that bare and painted floors are likely to represent the largest areal extent of contaminated concrete, followed by bare and painted walls and ceilings, then containments, and finally cracks and penetrations representing the smallest fraction of the problem. The difficulties associated with decontamination of the various problem areas were also considered. For example, cracks and penetrations may account for only a small portion of the problem, but are the most difficult to decontaminate, while floors may account for the largest portion of the problem but are the easiest to decontaminate. As mentioned previously, these factors were taken into consideration when ranking the technologies specific to problems.

Technologies with potential application to the problems were further evaluated based on estimated cost, secondary waste generation, and processing rates. Again, a relative rank (high, medium, low) was assigned to each technology based on a qualitative comparison of the criteria to the baseline technology. A high ranking indicates additional benefit of the technology over the baseline (i.e., lower cost or secondary waste generation, faster processing rates), medium indicates little or no added benefit, and low indicates a higher cost or secondary waste generation rate or a slower processing rate as compared to baseline technologies. The reported cost data used for evaluation are expected to be low due to the variations in how the data were reported and because capital costs cannot be apportioned as unit costs until the size of the demonstration (or ultimate use by the site) is determined. When capital costs are 
apportioned, it may change the individual cost rankings. Secondary waste generation rankings were typically high. This was assumed to be a reflection of the fact that emerging technologies are conceived and developed in part based on the ability of a process to reduce secondary waste. It is also interesting to note that the processing rates were typically slower than baseline technologies and, therefore, received a low ranking. It is likely that processing rates will increase as the technology is streamlined during development and commercialization.

Table 4.3 summarizes the results of the screening and evaluation process. In all cases, adequate technology performance was assumed. Additionally, it was assumed that unit disposal costs for liquid or solid secondary waste streams would be the same for each technology application. Due to the uncertainties associated with cost information for technologies that are not commercially developed, the best available cost information is reported for comparison (Table 3.6), but only a relative ranking was assigned based on the comparison between the emerging technology and the baseline technology. Cost data were solicited from private industry and technology developers and confirmed with information published in the open literature and DOE reports. For comparison and evaluation of cost, secondary waste generation, and processing rates, the baseline technologies were: washing for transferrable surfaces, mechanical scabbling for floors (bare and painted) and containments, needle gun scabbling and/or high-pressure washing for walls and ceilings (bare and painted), and jack-hammering for cracks and penetrations. These are shown at the end of Table 4.3. Parameters used during the comparison with the baseline technologies are included in Table 4.3.

\subsection{Conclusions}

The evaluation and matching process described in this section was the basis for recommendation of technologies to be demonstrated. Although the reasoning for the decision to demonstrate the technologies is beyond the scope of this report, the findings of the process provide valuable insight for concrete decontamination technology selection and implementation.

Candidate technologies were qualitatively ranked based on the relative ranking for each criteria, resulting in three different groupings: (1) demonstration is recommended, (2) demonstration may be considered, and (3) technology is removed from further consideration. Technologies in the first group were considered to provide the most potential benefit to decontamination of concrete within the DOE complex and include biological decontamination, electro-hydraulic scabbling, electrokinetics, and microwave scabbling. Biological decontamination has the potential to decontaminate a wide range of problems (a large fraction of contaminated concrete), fits a niche that is not currently addressed (long-term passive treatment), and may provide potential cost savings and waste reduction. Similarly, electrokinetic processes have the potential to decontaminate a large fraction of contaminated concrete within the DOE complex and apply to a niche that is not currently addressed (cracks and penetrations, contamination at depths greater than the surface inch) as well as having the potential for waste reduction. 
Electro-hydraulic scabbling ranked high for all criteria. A demonstration of this technology at Fernald is currently funded by Morgantown Energy Technology Center (METC). However, preliminary discussions with technology developers indicated an interest in demonstrations applicable to other problem areas. Finally, determination of the feasibility of microwave scabbling is required.

Technologies in the second group were considered to provide benefit to concrete decontamination but with specific application. Technologies in this group include chemical extraction (for application to cracks and penetrations or coupled with electrokinetic processes to determine if the processes can be optimized), chromographic strippable coatings (SensorCoat process is in early development stages but may provide characterization and waste minimization benefits), laser ablation (potential to significantly reduce secondary waste), and flashlamp (potential to significantly reduce secondary waste and when provided as a decontamination service, to reduce costs).

Technologies in the third group include $\mathrm{CO}_{2}$ blasting (and variations of the process), ice blasting, plasma torch, soda blasting and soft media blasting. These technologies were removed from further consideration based on two reasons. First, the technologies in this last group are essentially variations of baseline scabbling technologies and may be considered commercially available (at least for non-radiological contamination), therefore adding little benefit if demonstrated. Second, numerous commercial technology applications are available at lower cost for decontaminating the problem areas addressed by these technologies. It should be noted that the technologies in the third group may have the potential to significantly reduce waste generation compared to baseline technologies. 


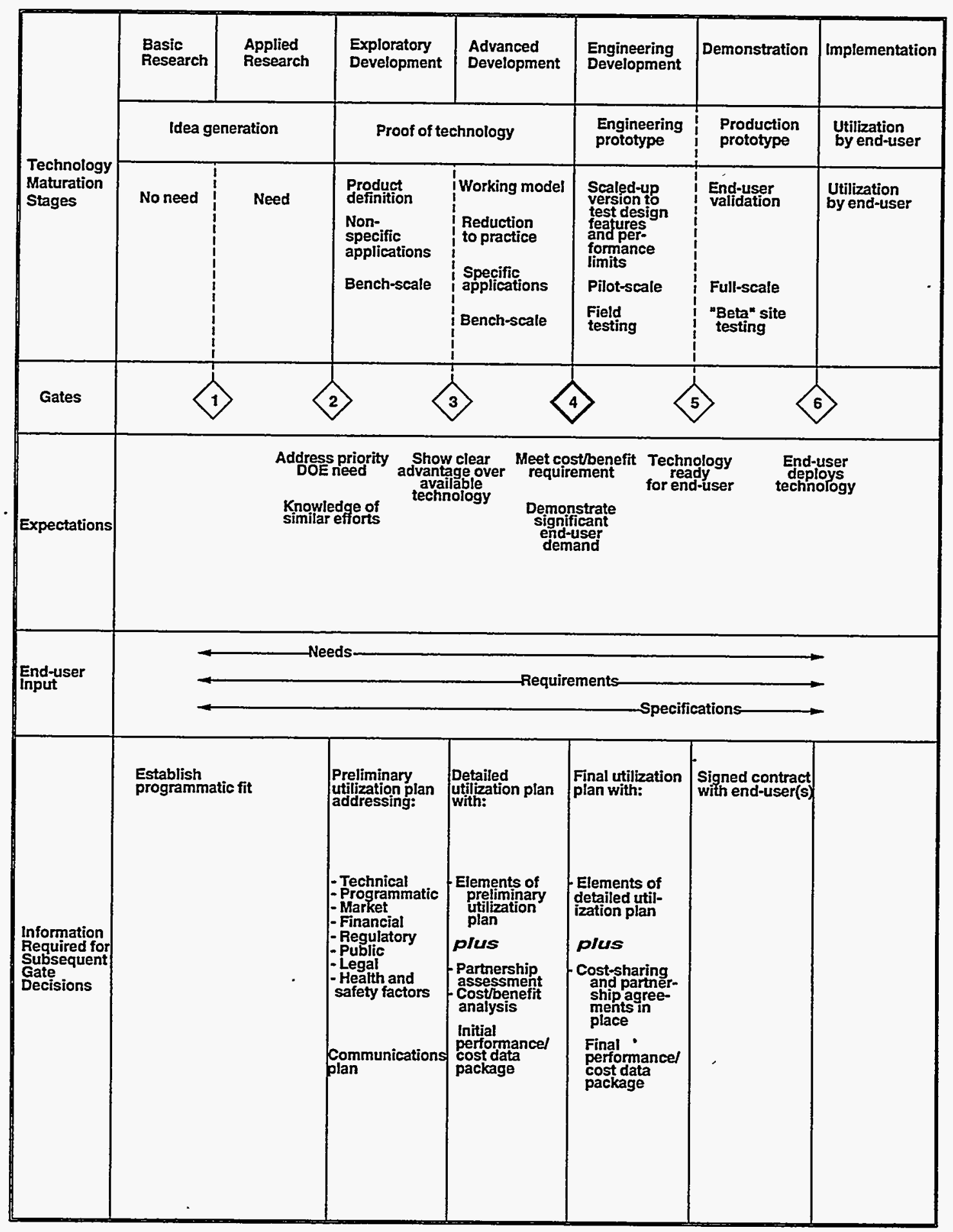

Fig. 4.1. Managing technologies for deployment. Source: Paladino, J., and P. Longsworth. $A$ Common Framework for Managing Technology Development in DOE's Environmental Cleanup Program (draft). Office of Technology Development, Office of Environmental Management. U.S. Department of Energy. Used with permission. 
Table 4.1. Matching of concrete decontamination problems with emerging technologies

\begin{tabular}{|c|c|c|c|c|c|c|c|}
\hline Problem & $\begin{array}{l}\text { Surface areas } \\
\text { (transferable) }\end{array}$ & Bare floors & Painted floors & $\begin{array}{c}\text { Surface areas } \\
\text { (fixed) } \\
\\
\text { Bare } \\
\text { walls/ceilings }\end{array}$ & $\begin{array}{c}\text { Painted } \\
\text { walls/ceilings } \\
\end{array}$ & $\begin{array}{l}\text { Containments } \\
\text { (basins/pools) }\end{array}$ & $\begin{array}{c}\text { Deep } \\
\text { contamination } \\
\text { (cracks and } \\
\text { penetrations) }\end{array}$ \\
\hline Technology & $\begin{array}{l}\text { Biological } \\
\mathrm{CO}_{2} \text { blasting } \\
\text { Chemical } \\
\text { extraction } \\
\text { Electro-hydraulic } \\
\text { scabbling } \\
\text { Flashlamp } \\
\text { Ice blasting } \\
\text { Laser ablation } \\
\text { Soda blasting } \\
\text { Soft media } \\
\text { blasting } \\
\text { Strippable } \\
\text { coatings } \\
\end{array}$ & $\begin{array}{l}\text { Biological } \\
\text { Chemical } \\
\quad \text { extraction } \\
\text { Electrokinetics } \\
\text { Electro-hydraulic } \\
\quad \text { scabbling } \\
\text { Flashlamp } \\
\text { Laser ablation } \\
\text { Microwave } \\
\text { Plasma torch } \\
\text { Soft media } \\
\quad \text { blasting }\end{array}$ & $\begin{array}{l}\text { Biological } \\
\text { Chemical } \\
\text { extraction } \\
\mathrm{CO}_{2} \text { blasting } \\
\text { Electro-hydraulic } \\
\text { scabbling } \\
\text { Flashlamp } \\
\text { Ice blasting } \\
\text { Laser ablation } \\
\text { Microwave } \\
\text { Plasma torch } \\
\text { Soda blasting } \\
\text { Soft media } \\
\text { blasting } \\
\end{array}$ & $\begin{array}{l}\text { Biological } \\
\text { Chemical } \\
\quad \text { extraction } \\
\text { Flashlamp } \\
\text { Laser ablation } \\
\text { Soft media } \\
\quad \text { blasting }\end{array}$ & $\begin{array}{l}\text { Biological } \\
\text { Chemical } \\
\quad \text { extraction } \\
\mathrm{CO}_{2} \text { blasting } \\
\text { Flashlamp } \\
\text { Ice blasting } \\
\text { Laser ablation } \\
\text { Soda blasting } \\
\text { Soft media } \\
\quad \text { blasting }\end{array}$ & $\begin{array}{l}\text { Biological } \\
\text { Chemical } \\
\quad \text { extraction } \\
\text { Electrokinetics } \\
\text { Electro-hydraulic } \\
\quad \text { scabbling } \\
\text { Flashlamp } \\
\text { Laser ablation } \\
\text { Microwave } \\
\text { Plasma torch } \\
\text { Soft media } \\
\quad \text { blasting }\end{array}$ & $\begin{array}{l}\text { Chemical } \\
\quad \text { extraction } \\
\text { Electrokinetics } \\
\text { Honing }\end{array}$ \\
\hline $\begin{array}{l}\text { Site and } \\
\text { Contaminants }\end{array}$ & All sites & $\begin{array}{l}\text { FEMP (U, Th) } \\
\text { HANF (Sr, Cs, } \\
\text { Pu, U, Tc, Co) } \\
\text { INEL (Co, Cs, Eu, } \\
\text { U, Sr, Pu) } \\
\text { K-25 (U, Tc, } \\
\text { TRU) } \\
\text { MND (Pu, tritium, } \\
\text { Th) } \\
\text { NTS( U, Pu, Am, } \\
\text { Sr, Co) } \\
\text { PORTS (U, Tc, } \\
\text { TRU) } \\
\text { PGDP (U) } \\
\text { RMIT (U) } \\
\text { SRS (U, Pu, Cs, } \\
\text { tritium) }\end{array}$ & $\begin{array}{l}\text { ANL (Co, Cs) } \\
\text { HANF (Sr, Cs, } \\
\text { Pu, U, Tc, Co) } \\
\text { INEL (Co, Cs, Eu, } \\
\text { U, Sr, Pu) } \\
\text { LANL (Pu, U) } \\
\text { ORNL (Cs, Co, } \\
\text { Sr, U, Th) } \\
\text { RFETS (Pu, U) }\end{array}$ & $\begin{array}{l}\text { FEMP (U, Th) } \\
\text { INEL (Co, Cs, Eu, } \\
\text { U, Sr, Pu) } \\
\text { K-25 (U, Tc, } \\
\text { TRU) } \\
\text { PORTS (U, Tc, } \\
\text { TRU) } \\
\text { PGDP (U) } \\
\text { SRS. (U, Pu, Cs, } \\
\text { tritium) }\end{array}$ & $\begin{array}{l}\text { ANL (Co, Cs) } \\
\text { HANF (Sr, Cs, } \\
\text { Pu, U, Tc, Co) } \\
\text { INEL (Co, Cs, Eu, } \\
\text { U, Sr, Pu) } \\
\text { LANL (Pu, U) } \\
\text { ORNL (Cs, Co, } \\
\text { Sr, U, Th) } \\
\text { RFETS (Pu, U) }\end{array}$ & $\begin{array}{l}\text { BNL (U, Pu, } \\
\text { tritium) } \\
\text { HANF ( } \mathrm{Sr}, \mathrm{Cs}, \\
\text { Pu, U, Tc, Co) } \\
\text { SRS (U, Pu, Cs, } \\
\text { tritium) }\end{array}$ & All sites \\
\hline
\end{tabular}

Note: Bulk contamination was assumed to be activated concrete associated with reactors and, therefore, inappropriate for decontamination processes. 


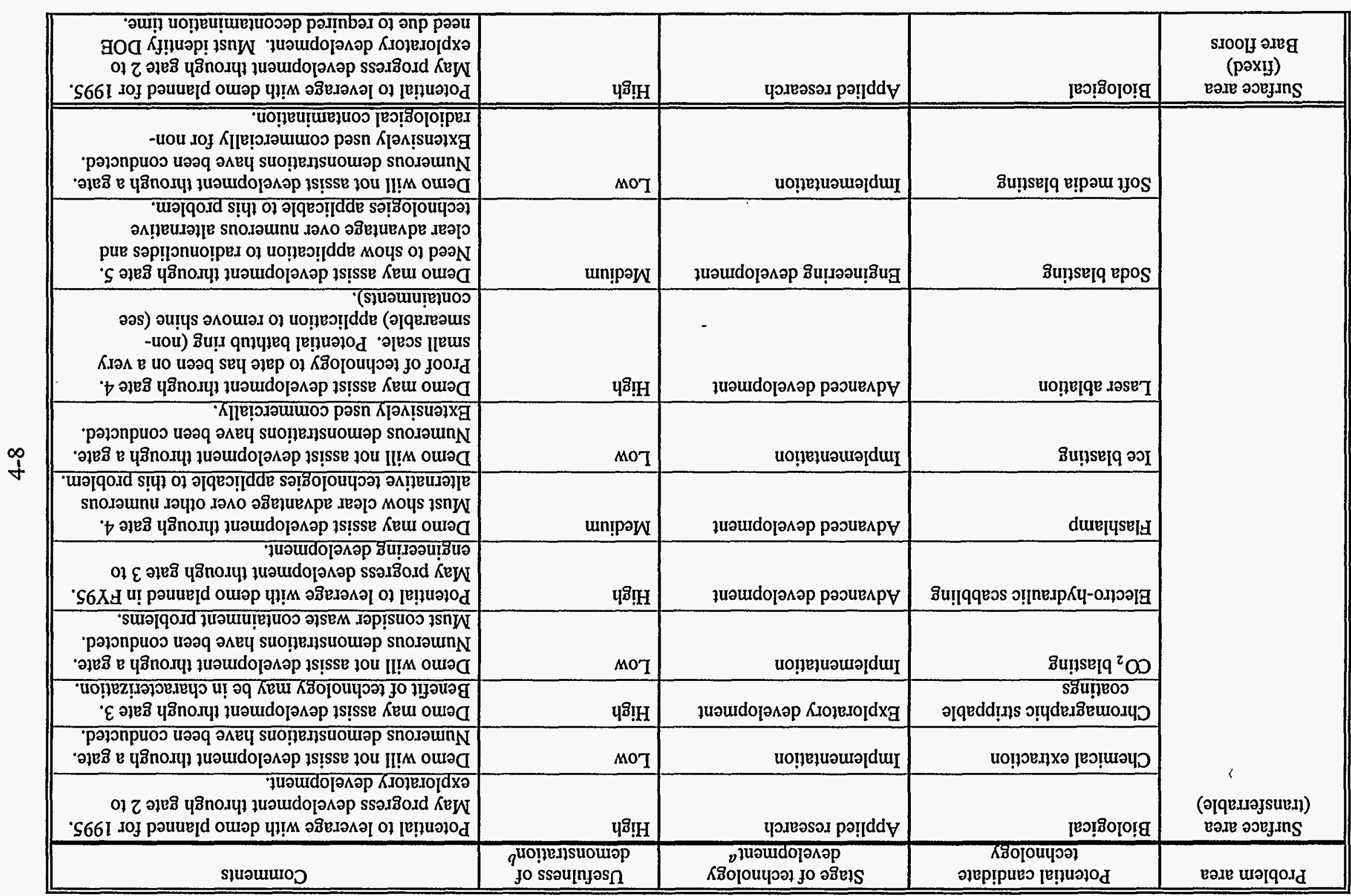


Table 4.2. (continued)

\begin{tabular}{|c|c|c|c|c|}
\hline Problem area & $\begin{array}{l}\text { Potential candidate } \\
\text { technology }\end{array}$ & $\begin{array}{c}\text { Stage of technology } \\
\text { development }\end{array}$ & $\begin{array}{c}\text { Usefulness of } \\
\text { demonstration }^{b}\end{array}$ & Comments \\
\hline & Chemical extraction & Implementation & Low & $\begin{array}{l}\text { Demo will not assist development through a gate. } \\
\text { Several demonstrations have been conducted. }\end{array}$ \\
\hline & Electrokinetics & Exploratory development & High & $\begin{array}{l}\text { Demo may assist development through gate } 3 . \\
\text { Potential to leverage with } N \text { reactor pool. }\end{array}$ \\
\hline & Electro-hydraulic scabbling & Advanced development & High & $\begin{array}{l}\text { Potential to leverage with demo planned in FY95. } \\
\text { May progress development through gate } 4 \text { to } \\
\text { engineering development. }\end{array}$ \\
\hline & Flashlamp & Advanced development & Medium & $\begin{array}{l}\text { Demo may assist development through gate } 4 . \\
\text { Must show clear advantage over other numerous } \\
\text { alternative technologies applicable to this problem. }\end{array}$ \\
\hline & Microwave & Advanced development & High & $\begin{array}{l}\text { Demo may assist development through gate } 4 . \\
\text { Potential leveraging may assist with field testing. } \\
\text { Must show cost/benefit ratio. }\end{array}$ \\
\hline & Plasma torch & Exploratory development & Low & $\begin{array}{l}\text { Unclear if demo will assist development through a } \\
\text { gate. Interest in development is not clear. }\end{array}$ \\
\hline & Soft media blasting & Implementation & Low & $\begin{array}{l}\text { Demo will not assist development through a gate. } \\
\text { Numerous demonstrations have been conducted. } \\
\text { Extensively used commercially for non- } \\
\text { radiological contamination. }\end{array}$ \\
\hline \multirow[t]{5}{*}{$\begin{array}{l}\begin{array}{l}\text { Surface area } \\
\text { (fixed) }\end{array} \\
\text { Painted floors }\end{array}$} & Biological & Applied research & High & $\begin{array}{l}\text { Potential to leverage with demo planned for } 1995 . \\
\text { May progress development through gate } 2 \text { to } \\
\text { exploratory developments. Must identify DOE } \\
\text { need due to required decontamination time. }\end{array}$ \\
\hline & Chemical extraction & Demonstration & Medium & $\begin{array}{l}\text { Demo may assist development through gate } 6 \text { to } \\
\text { commercialization. Must consider containment } \\
\text { and neutralization of chelators. }\end{array}$ \\
\hline & $\mathrm{CO}_{2}$ blasting & Implementation & Low & $\begin{array}{l}\text { Demo will not assist development through a gate. } \\
\text { Numerous demonstrations have been conducted. } \\
\text { Must consider waste containment problems }\end{array}$ \\
\hline & Electro-hydraulic scabbling & Advanced development & High & $\begin{array}{l}\text { Potential to leverage with demo planned in FY95. } \\
\text { May progress tech development through gate } 4 \text { to } \\
\text { engineering development. }\end{array}$ \\
\hline & Flashlamp & Advanced development & Medium & $\begin{array}{l}\text { Demo may assist development through gate } 4 . \\
\text { Must show clear advantage over other numerous } \\
\text { alternative technologies applicable to this problem. }\end{array}$ \\
\hline
\end{tabular}


Table 4.2. (continued)

\begin{tabular}{|c|c|c|c|c|}
\hline Problem area & $\begin{array}{l}\text { Potential candidate } \\
\text { technology }\end{array}$ & $\begin{array}{l}\text { Stage of technology } \\
\text { development }\end{array}$ & $\begin{array}{c}\text { Usefulness of } \\
\text { demonstration }^{b}\end{array}$ & Comments \\
\hline & Ice blasting & Implementation & Low & $\begin{array}{l}\text { Demo will not assist development through a gate. } \\
\text { Numerous demonstrations have been conducted. } \\
\text { Extensively used commercially. }\end{array}$ \\
\hline & Laser ablation & Advanced development & Medium & $\begin{array}{l}\text { Demo may assist development through gate } 4 . \\
\text { Proof of technology to date has been on a very } \\
\text { small scale. Must show clear advantage over other } \\
\text { technologies. }\end{array}$ \\
\hline & Microwave & Advanced development & High & $\begin{array}{l}\text { Demo may assist development through gate } 4 \text {. } \\
\text { Potential leveraging may assist with field testing. } \\
\text { Must show cost/benefit ratio. }\end{array}$ \\
\hline & Plasma torch & Exploratory development & Low & $\begin{array}{l}\text { Unclear if demo will assist development through a } \\
\text { gate. Interest in development is not clear. }\end{array}$ \\
\hline & Soda blasting & Engineering development & Medium & $\begin{array}{l}\text { Demo may assist development through gate } 5 \text {. } \\
\text { Need to show application to radionuclides and } \\
\text { clear advantage over numerous alternative } \\
\text { technologies applicable to this problem. }\end{array}$ \\
\hline & Soft media blasting & Implementation & Low & $\begin{array}{l}\text { Demo will not assist development through a gate. } \\
\text { Numerous demonstrations have been conducted. } \\
\text { Extensively used commercially for non- } \\
\text { radiological contamination. }\end{array}$ \\
\hline \multirow[t]{4}{*}{$\begin{array}{c}\begin{array}{c}\text { Surface area } \\
\text { (fixed) }\end{array} \\
\text { Bare walls/ceilings }\end{array}$} & Biological & Applied research & High & $\begin{array}{l}\text { Potential to leverage with demo planned for } 1995 \text {. } \\
\text { May progress development through gate } 2 \text { to } \\
\text { exploratory development. Must identify DOE } \\
\text { need due to required decontamination time. }\end{array}$ \\
\hline & Chemical extraction & Implementation & Low & $\begin{array}{l}\text { Demo will not assist development through a gate. } \\
\text { Several demonstrations have been conducted. }\end{array}$ \\
\hline & Flashlamp & Advanced development & Medium & $\begin{array}{l}\text { Demo may assist development through gate } 4 . \\
\text { Must show clear advantage over other numerous } \\
\text { alternative technologies applicable to this problem. }\end{array}$ \\
\hline & Soft media blasting & Implementation & Low & $\begin{array}{l}\text { Demo will not assist development through a gate. } \\
\text { Numerous demonstrations have been conducted. } \\
\text { Extensively used commercially for non- } \\
\text { radiological contamination. }\end{array}$ \\
\hline $\begin{array}{c}\text { Surface area } \\
\text { (fixed) } \\
\text { Paintedwalls/ceilings }\end{array}$ & Biological & Applied research & High & $\begin{array}{l}\text { Potential to leverage with demo planned for } 1995 \text {. } \\
\text { May progress development through gate } 2 \text { to } \\
\text { exploratory development. Must identify DOE } \\
\text { need due to required decontamination time. }\end{array}$ \\
\hline
\end{tabular}


Table 4.2. (continued)

\begin{tabular}{|c|c|c|c|c|}
\hline Problem area & $\begin{array}{l}\text { Potential Candidate } \\
\text { Technology }\end{array}$ & $\begin{array}{l}\text { Stage of Technology } \\
\text { Development }{ }^{\mathrm{a}}\end{array}$ & $\begin{array}{c}\text { Usefulness of } \\
\text { Demonstration }\end{array}$ & Comments \\
\hline & Chemical extraction & Demonstration & Medium & $\begin{array}{l}\text { Demo may assist development through gate } 6 \text { to } \\
\text { commercialization. Must consider containment } \\
\text { and neutralization of chelators. }\end{array}$ \\
\hline & $\mathrm{CO}_{2}$ blasting & Implementation & Low & $\begin{array}{l}\text { Demo will not assist development through a gate. } \\
\text { Numerous demonstrations have been conducted. } \\
\text { Must consider waste containment problems. }\end{array}$ \\
\hline & $\overline{\text { Flashlamp }}$ & Advanced development & Medium & $\begin{array}{l}\text { Demo may assist development through gate } 4 . \\
\text { Must show clear advantage over other numerous } \\
\text { alternative technologies applicable to this problem. }\end{array}$ \\
\hline & Ice blasting & Implementation & Low & $\begin{array}{l}\text { Demo will not assist development through a gate. } \\
\text { Numerous demonstrations have been conducted. } \\
\text { Extensively used commercially. }\end{array}$ \\
\hline & Laser ablation & Advanced development & Medium & $\begin{array}{l}\text { Demo may assist development through gate } 4 . \\
\text { Proof of technology to date has been on a very } \\
\text { small scale. Must show clear advantage over other } \\
\text { technologies. }\end{array}$ \\
\hline & Soda blasting & Engineering development & Medium & $\begin{array}{l}\text { Demo may assist development through gate } 5 . \\
\text { Need to show application to radionuclides and } \\
\text { clear advantage over numerous alternative } \\
\text { technologies applicable to this problem. }\end{array}$ \\
\hline & Soft media blasting & Implementation & Low & $\begin{array}{l}\text { Demo will not assist development through a gate. } \\
\text { Numerous demonstrations have been conducted. } \\
\text { Extensively used commercially for non- } \\
\text { radiological contamination. }\end{array}$ \\
\hline \multirow[t]{4}{*}{$\begin{array}{l}\text { Surface area } \\
\text { (fixed) } \\
\text { Containments } \\
\text { (basins/pools) }\end{array}$} & Biological & Applied research & High & $\begin{array}{l}\text { Potential to leverage with demo planned for } 1995 . \\
\text { May progress development through gate } 2 \text { to } \\
\text { exploratory development. Must identify DOE } \\
\text { need due to required decontamination time. }\end{array}$ \\
\hline & \begin{tabular}{|l|} 
Chemical extraction \\
\end{tabular} & Implementation & Low & $\begin{array}{l}\text { Demo will not assist development through a gate. } \\
\text { Several demonstrations have been conducted. }\end{array}$ \\
\hline & Electrokinetics & Exploratory development & High & $\begin{array}{l}\text { Demo may assist development through gate } 3 . \\
\text { Potential to leverage with } \mathrm{N} \text { reactor pool. }\end{array}$ \\
\hline & Electro-hydraulic scabbling & Advanced development & High & $\begin{array}{l}\text { Potential to leverage with demo planned in FY95. } \\
\text { May progress development through gate } 4 \text { to } \\
\text { engineering development. }\end{array}$ \\
\hline
\end{tabular}


Table 4.2. (continued)

\begin{tabular}{|c|c|c|c|c|}
\hline Problem area & $\begin{array}{l}\text { Potential candidate } \\
\text { technology }\end{array}$ & $\begin{array}{l}\text { Stage of technology } \\
\text { development }\end{array}$ & $\begin{array}{c}\text { Usefulness of } \\
\text { demonstration }^{b}\end{array}$ & Comments \\
\hline & Flashlamp & Advanced development & Medium & $\begin{array}{l}\text { Demo may assist development through gate } 4 \text {. } \\
\text { Must show clear advantage over other numerous } \\
\text { alternative technologies applicable to this problem. }\end{array}$ \\
\hline & Laser ablation & Advanced development & Medium & $\begin{array}{l}\text { Demo may assist development through gate } 4 . \\
\text { Proof of technology to date has been on a very } \\
\text { small scale. Potential bathtub ring (non- } \\
\text { smearable) application to remove shine. }\end{array}$ \\
\hline & Microwave & Advanced development & High & $\begin{array}{l}\text { Demo may assist development through gate } 4 . \\
\text { Potential leveraging may assist with field testing. } \\
\text { Must show cost/benefit ratio. }\end{array}$ \\
\hline & Plasma torch & Exploratory development & Low & $\begin{array}{l}\text { Unclear if demo will assist development through a } \\
\text { gate. Interest in development is not clear. }\end{array}$ \\
\hline & Soft media blasting & Implementation & Low & $\begin{array}{l}\text { Demo will not assist development through a gate. } \\
\text { Numerous demonstrations have been conducted. } \\
\text { Extensively used commercially for non- } \\
\text { radiological contamination. }\end{array}$ \\
\hline \multirow[t]{4}{*}{$\begin{array}{l}\text { Deep contamination } \\
\text { (cracks and } \\
\text { penetrations) }\end{array}$} & Chemical extraction & Demonstration & High & $\begin{array}{l}\text { Demo may assist development through gate } 6 \text { to } \\
\text { commercialization. Must consider containment } \\
\text { and neutralization of chelators. Few technologies } \\
\text { address this problem. }\end{array}$ \\
\hline & Electro-hydraulic scabbling & Advanced development & High & $\begin{array}{l}\text { Potential to leverage with demo planned in FY95. } \\
\text { May progress development through gate } 4 \text { to } \\
\text { engineering development. Containment of the } \\
\text { water must be considered for application to this } \\
\text { problem. }\end{array}$ \\
\hline & Electrokinetics & Exploratory development & High & $\begin{array}{l}\text { Demo may assist development through gate } 3 \text {. } \\
\text { Potential to leverage with } \mathrm{N} \text { reactor pool. Few } \\
\text { technologies address this problem. }\end{array}$ \\
\hline & Microwave & Advanced development & Medium & $\begin{array}{l}\text { Demo may assist development through gate } 4 . \text {, but } \\
\text { it is unclear if the technology will be applicable to } \\
\text { this problem (technology will require modification } \\
\text { for this application). Potential leveraging may } \\
\text { assist with field testing. Must show cost/benefit } \\
\text { ratio. }\end{array}$ \\
\hline
\end{tabular}


Table 4.2. (continued)

\begin{tabular}{|c|l|l|l|l|}
\hline Problem area & \multicolumn{1}{|c|}{$\begin{array}{c}\text { Potential candidate } \\
\text { technology }\end{array}$} & \multicolumn{1}{|c|}{$\begin{array}{c}\text { Stage of technology } \\
\text { development } a\end{array}$} & $\begin{array}{c}\text { Usefulness of } \\
\text { demonstration }\end{array}$ & \\
\hline & Honing & Implementation & Low & $\begin{array}{c}\text { Demo will not assist development through a gate. } \\
\text { Applicable to penetrations such as borings, etc. }\end{array}$ \\
\hline
\end{tabular}

a Stage of development is defined on Fig. 4.1.

$b$ Based on the usefulness of a demonstration to move the technology along on the implementation continuum (i.e., benefit from a demonstration to assist a technology through a "gate" and to the next stage of development, Fig. 4.1). 
Table 4.3. Results from technology demonstration evaluation

\begin{tabular}{|c|c|c|c|c|c|c|}
\hline Technology & $\begin{array}{l}\text { Number of } \\
\text { applicable } \\
\text { problems }\end{array}$ & $\begin{array}{l}\text { Usefulness } \\
\text { of demo }\end{array}$ & Estimated cost $t^{c}$ & $\begin{array}{l}\text { Secondary } \\
\text { waste } \\
\text { generation }^{d}\end{array}$ & $\begin{array}{l}\text { Processing } \\
\text { rates }^{e}\end{array}$ & Comments \\
\hline Biological & 6 & High & High & High & Low & $\begin{array}{l}\text { Waste volumes are assumed to be slightly less } \\
\text { than the baseline technology primarily due to } \\
\text { smaller particle size compared to the size of } \\
\text { the scabbled concrete. Advantages include } \\
\text { low worker exposure, low labor requirements, } \\
\text { controlled removal, the fact that the process } \\
\text { does not drive the contaminant further into the } \\
\text { concrete, and application to a wide variety of } \\
\text { problems and configurations. Limitations } \\
\text { include slow processing rates and careful } \\
\text { control of the operating conditions (relative } \\
\text { humidity and nutrients). }\end{array}$ \\
\hline Chemical extraction & 7 & Medium & Medium high & High & Medium & $\begin{array}{l}\text { Several vendors have completed or are in the } \\
\text { process of conducting demonstrations; thus the } \\
\text { technology may be considered as a commercial } \\
\text { process with low benefit for additional } \\
\text { demonstrations. It might be considered as an } \\
\text { enhancement to the electrokinetic process. } \\
\text { Advantages of the process are minimal worker } \\
\text { exposure, minimization of secondary waste, } \\
\text { and the fact that the concrete surface is not } \\
\text { harmed or destroyed. Limitations include } \\
\text { depth of chemical penetration for } \\
\text { decontamination and disposal of secondary } \\
\text { waste (may be considered as a mixed waste). }\end{array}$ \\
\hline $\begin{array}{l}\text { Chromographic } \\
\text { strippable coatings }\end{array}$ & 1 & High & Unknown & High & Unknown & $\begin{array}{l}\text { Technology is a variation of strippable } \\
\text { coatings and is in the early stages of } \\
\text { development. Bench-top experiments have } \\
\text { shown "proof of principle," but more specific } \\
\text { information is not available. Advantage is } \\
\text { identification of hot spots during application, } \\
\text { thus minimizing extent of the area treated. }\end{array}$ \\
\hline $\mathrm{CO}_{2}$ blasting & 3 & Low & Medium low & High & Medium & $\begin{array}{l}\text { Several variations of the technology are being } \\
\text { developed. However, } \mathrm{CO}_{2} \text { blasting is } \\
\text { considered to be commercially available; thus } \\
\text { a demonstration would provide limited } \\
\text { benefits. }\end{array}$ \\
\hline
\end{tabular}


Table 4.3. (continued)

\begin{tabular}{|c|c|c|c|c|c|c|}
\hline Technology & $\begin{array}{l}\text { Number of } \\
\text { Applicable } \\
\text { Problems }^{\text {a }}\end{array}$ & $\begin{array}{l}\text { Usefulness } \\
\text { of Demo }\end{array}$ & Estimated Cost ${ }^{c}$ & $\begin{array}{l}\text { Secondary } \\
\text { Waste } \\
\text { Generation }\end{array}$ & $\begin{array}{c}\text { Processing } \\
\text { Rates }^{\mathrm{e}}\end{array}$ & Comments \\
\hline Electrokinetics & 3 & High & Unavailable & High & Low & $\begin{array}{l}\text { Cost estimates are not available at this time. } \\
\text { Additionally, secondary waste volumes are } \\
\text { expected to be minimized compared to } \\
\text { baseline technologies but have not yet been } \\
\text { quantified. Advantages of the process are } \\
\text { minimal worker exposure, minimization of } \\
\text { secondary waste, and the fact that the concrete } \\
\text { surface is not harmed or destroyed. } \\
\text { Disadvantages include slower processing rates. }\end{array}$ \\
\hline $\begin{array}{l}\text { Electro-hydraulic } \\
\text { scabbling }\end{array}$ & 5 & High & High & Medium & Low & $\begin{array}{l}\text { This technology is expected to be sold as a } \\
\text { service; therefore, capital costs are not } \\
\text { applicable. Operating costs may vary as } \\
\text { development of the process continues. } \\
\text { Secondary waste is slightly higher than the } \\
\text { baseline due to the use of water for scabbling. } \\
\text { However, water recycling and dust } \\
\text { minimization (i.e., reduced worker exposure to } \\
\text { dust) may off set the limitations. }\end{array}$ \\
\hline Flashlamp & 6 & Medium & Medium & High & Medium & $\begin{array}{l}\text { This technology is expected to be sold as a } \\
\text { service; therefore, capital costs are not } \\
\text { applicable. Essentially this process would be } \\
\text { used to remove surface coatings only, but may } \\
\text { also fix contamination in place (e.g., } \\
\text { vitrification of concrete). It produces an ash } \\
\text { waste of } ~ 25 \% \text { of the baseline technology } \\
\text { generated waste volume. Advantages include } \\
\text { low waste volume and the fact that it does not } \\
\text { drive contaminants into the concrete nor } \\
\text { damage the surface. Limitations include } \\
\text { difficulty of maneuvering the equipment to } \\
\text { decontaminate corners and tight places. }\end{array}$ \\
\hline Ice blasting & 3 & Low & Medium & Low & Medium & $\begin{array}{l}\text { Ice blasting is considered to be commercially } \\
\text { available; thus, a demonstration would provide } \\
\text { limited benefits. }\end{array}$ \\
\hline
\end{tabular}


Table 4.3. (continued)

\begin{tabular}{|c|c|c|c|c|c|c|}
\hline Technology & $\begin{array}{l}\text { Number of } \\
\text { applicable } \\
\text { problems }{ }^{a}\end{array}$ & $\begin{array}{l}\text { Usefulness } \\
\text { of demo }\end{array}$ & Estimated cost ${ }^{c}$ & $\begin{array}{l}\text { Secondary } \\
\text { waste } \\
\text { generation } \\
\end{array}$ & $\begin{array}{c}\text { Processing } \\
\text { rates }^{e}\end{array}$ & Comments \\
\hline Laser ablation & 4 & Medium & Medium low & High & Low & $\begin{array}{l}\text { This technology is expected to be sold as a } \\
\text { service; therefore, capital costs are not } \\
\text { applicable. Essentially this process would be } \\
\text { used to remove surface coatings only. It } \\
\text { produces an ash waste of } \sim 25 \% \text { of the baseline } \\
\text { technology generated waste volume. } \\
\text { Advantages include low waste volume and the } \\
\text { fact that it does not drive contaminants into the } \\
\text { concrete nor damage the surface. Limitations } \\
\text { include difficulty of maneuvering the } \\
\text { equipment to decontaminate corners and tight } \\
\text { places. }\end{array}$ \\
\hline Microwave scabbling & $\overline{4}$ & $\begin{array}{c}\text { Medium } \\
\text { high }\end{array}$ & Medium low & Medium & Low & $\begin{array}{l}\text { Although the technology has been used } \\
\text { internationally (Japan), it is considered to be } \\
\text { available only through the DOE system in the } \\
\text { United States. Secondary waste may be } \\
\text { slightly higher than the baseline due to the } \\
\text { larger size of the scabbled concrete. } \\
\text { Advantages include minimization of air-borne } \\
\text { particles and applicability to high radiation } \\
\text { areas if remotely operated. Modifications to } \\
\text { the system may have application to } \\
\text { decontamination of walls. Limitations include } \\
\text { difficulty of maneuvering the equipment to } \\
\text { decontaminate corners and tight places. }\end{array}$ \\
\hline Plasma torch & 3 & Low & Medium & High & Low & $\begin{array}{l}\text { This process would be used to remove surface } \\
\text { coatings only: It produces an ash waste of } \sim \\
25 \% \text { of the baseline technology generated } \\
\text { waste volume. Advantages include low waste } \\
\text { volume and the fact that it does not drive } \\
\text { contaminants into the concrete or damage the } \\
\text { surface. Limitations include development } \\
\text { costs and difficulty of maneuvering the } \\
\text { equipment to decontaminate corners and tight } \\
\text { places. }\end{array}$ \\
\hline
\end{tabular}


Table 4.3. (continued)

\begin{tabular}{|c|c|c|c|c|c|c|}
\hline Technology & $\begin{array}{l}\text { Number of } \\
\text { applicable } \\
\text { problems }^{a}\end{array}$ & $\begin{array}{l}\text { Usefulness } \\
\text { of demo }{ }^{b}\end{array}$ & Estimated $\operatorname{cost}^{c}$ & $\begin{array}{l}\text { Secondary } \\
\text { waste } \\
\text { generation }^{d}\end{array}$ & $\begin{array}{l}\text { Processing } \\
\text { rates }^{e}\end{array}$ & Comments \\
\hline Soda blasting & 3 & Medium & Medium & High & Medium & $\begin{array}{l}\text { Although secondary waste volumes will be } \\
\text { slightly less than baseline technologies, } \\
\text { treatment of the waste may be a limitation. } \\
\text { The technology has been demonstrated at } \\
\text { numerous non-radioactive sites and has been } \\
\text { modified for decontamination of radioactive } \\
\text { surfaces (recently demonstrated at K-25); } \\
\text { therefore, additional demonstrations may } \\
\text { provide limited benefits. }\end{array}$ \\
\hline Soft media blasting & $\overline{6}$ & Low & Medium low & Medium & Medium & $\begin{array}{l}\text { This technology is expected to be sold as a } \\
\text { service; therefore, capital costs are not } \\
\text { applicable. Waste volumes will be slightly less } \\
\text { than baseline technologies depending on the } \\
\text { efficiency of recycling the soft media. The } \\
\text { technology has been applied to non-radioactive } \\
\text { contamination and is being modified for } \\
\text { decontamination of radioactive surfaces; } \\
\text { therefore, the technology is considered to be } \\
\text { commercially available. A demonstration } \\
\text { would provide limited benefits. }\end{array}$ \\
\hline $\begin{array}{l}\text { Mechanical scabbling } \\
\text { Scarifier } \\
\text { Grit blasting } \\
\text { Shot blasting }\end{array}$ & Baseline & NA & $\begin{array}{l}\$ 7 \text { to } 12.6 / \mathrm{ft}^{2} \\
\$ 6.65 / \mathrm{ft}^{2} \\
\$ 0.31 \text { to } 5.02 / \mathrm{ft}^{2}\end{array}$ & $\begin{array}{c}0.083 \mathrm{ft}^{3} / \mathrm{ft}^{2} \\
0.031 \mathrm{ft}^{3} / \mathrm{ft}^{2} \\
0.003 \text { to } 0.029 \\
\mathrm{ft}^{3} / \mathrm{ft}^{2}\end{array}$ & $\begin{array}{c}315 \text { to } 323 \mathrm{ft}^{2} / \mathrm{h} \\
47 \mathrm{ft}^{2} \mathrm{~h} \\
\text { Variable }\end{array}$ & $\begin{array}{l}\text { Baseline technology for fixed contamination in } \\
\text { floors (bare and painted) and containment } \\
\text { problem areas. }\end{array}$ \\
\hline Needle gun scabbling & Baseline & $\overline{\mathrm{NA}}$ & $\$ 13.06 / \mathrm{ft}^{2}$ & $0.0026 \mathrm{ft}^{3} / \mathrm{ft}^{2}$ & Unavailable & $\begin{array}{l}\text { Baseline technology for fixed contamination in } \\
\text { walls and ceilings (bare and painted). }\end{array}$ \\
\hline High-pressure washing & Baseline & $\mathrm{NA}$ & $\$ 16.91 / \mathrm{ft}^{2}$ & $0.028 \mathrm{ft}^{3} / \mathrm{ft}^{2}$ & $377 \mathrm{ft}^{2} / \mathrm{h}$ & $\begin{array}{l}\text { Baseline technology for fixed contamination in } \\
\text { walls and ceilings (bare and painted). }\end{array}$ \\
\hline Washing/scrubbing & Baseline & $\overline{\mathrm{NA}}$ & $<\$ 1 / \mathrm{ft}^{2}$ & Variable & Variable & $\begin{array}{l}\text { Baseline technology for transferable } \\
\text { contamination. }\end{array}$ \\
\hline
\end{tabular}

a Seven problems areas were identified and used for comparison (see Table 4.1).

$b$ " High ranking indicates an assumed greater benefit from a demonstration (see Table 4.2).

c High ranking indicates an assumed process operation cost savings compared to baseline technologies, medium indicates minimal (or no) benefit, and low indicates a higher process operation cost per unit. Capital cost was not included in the evaluation because these costs can not be evaluated as unit costs until a specific application (extent of contamination to be decontaminated) is identified.

d High ranking indicates an ass umed reduction in secondary waste compared to baseline technologies, medium indicates minimal (or no) benefit, and low indicates increased secondary waste generation.

$e$ High ranking indicates a faster processing rate compared to baseline technologies, medium indicates minimal (or no) benefit, and low indicates a slower processing rate.

NA $=$ not applicable 


\section{Summary}

The information presented in this report was obtained as part of a larger project to demonstrate emerging technologies for concrete decontamination. Findings from the problem definition tasks, which described the nature and extent of contaminated concrete and candidate emerging technologies, provide valuable information to technology developers as well as personnel responsible for technology selection and implementation. Efforts were focused on assimilation and review of existing information (e.g., BEMR and SFIA data bases, technology logic diagrams) to minimize duplication of previous efforts and, at the same time, to gather currently available information into one location to provide a general perspective on contaminated concrete.

The majority of the DOE sites are still in active use or in the initial stages of characterization. Thus, contaminated concrete in the DOE complex cannot be comprehensively defined until characterization is complete. However, the available information provides general trends associated with contaminated concrete within the $\mathrm{DOE}$ complex and insight into potential areas of concern in the future and areas that require more data.

It is evident from the variety of facility types within DOE that contaminants in concrete are wide-ranging. The most frequently reported contaminants are ${ }^{137} \mathrm{Cs}$ and ${ }^{28} \mathrm{U}$ and its daughters, closely followed by ${ }^{\circ 0} \mathrm{Co},{ }^{\circ 0} \mathrm{Sr}$, and tritium. Because complete characterization information is not available for several sites (including the gaseous diffusion plants), the order of the frequency of these contaminants in expected to change. For example, ${ }^{238} \mathrm{U}$ may have a greater occurrence than ${ }^{137} \mathrm{Cs}$. However, it is expected that ${ }^{137} \mathrm{Cs}$, ${ }^{288} \mathrm{U},{ }^{60} \mathrm{Co},{ }^{90} \mathrm{Sr}$, and tritium will remain as the most commonly occurring isotopes within the DOE complex.

Inventories of contaminated buildings suggest the potential for an enormous amount of contaminated concrete. The total area of contaminated concrete within the DOE complex is estimated to be in the range of $7.9 \times 10^{8} \mathrm{ft}^{2}$ or approximately 18,000 acres. The volume of contaminated concrete is estimated at $6.7 \times 10^{6} \mathrm{ft}^{3}$. These estimates do not represent the complete extent of concrete contamination because they are based on incomplete and differing data available from the sites. Although volume estimates of contaminated concrete were not available at most sites, the common finding was that most of the concrete contamination is surficial in nature and decreases with depth. Past experience indicated that scabbling is typically required to depths of $\sim 1$ in. or less. Tritium and technetium penetrate concrete more deeply and pose problems at several sites, including SRS and LANL.

The sites identified as having the most contaminated concrete are HANF, FEMP and ORR. These estimates do not include complete information from INEL, SRS, PORTS, PGDP, and RFETS, all of which are expected to have similar amounts of contaminated concrete. 
Based on the uncertainties of the available data describing the extent of contamination, it is not possible to accurately estimate the percentage of the total contaminated concrete represented by specific problem areas (e.g., $75 \%$ of the contaminated concrete within the DOE complex is associated with bare floors). However, general trends indicate that bare and painted floors are likely to represent the largest areal extent of contaminated concrete, followed by bare and painted walls and ceilings, containments (basins and pools), and finally cracks and penetrations as the smallest fraction of the problem.

Concrete decontamination needs were identified as: (1) reduction of secondary waste (rubble and liquid), (2) cost- and schedule-effective technologies, (3) more efficient removal of the concrete surface layer, (4) innovative technologies for floor and wall decontamination, and (5) unknown. When sites were asked which decontamination problems they faced, most replied with "unknown". This is attributed to the fact that D\&D planning and implementation is still in preliminary stages at many sites.

When comparing emerging technologies to existing, baseline technologies, secondary waste generation is typically less for emerging technologies. This may be a reflection of the fact that emerging technologies are conceived and developed in part to reduce secondary waste. Processing rates for emerging technologies are typically slower than for baseline technologies. However, it is likely that processing rates will increase as the technologies are streamlined during development and commercialization. Finally, comparison of cost data is difficult due to variations in how the data are reported and because capital costs cannot be apportioned as unit costs until the size of the demonstration (or ultimate use by the site) is determined.

Candidate technologies were qualitatively ranked based on the relative ranking of the above criteria, resulting in three different groupings: (1) demonstration is recommended, (2) demonstration may be considered, and (3) technology is removed from further consideration. Technologies in the first group were considered to provide the most potential benefit to decontamination of concrete within the DOE complex and include biological decontamination, electro-hydraulic scabbling, electrokinetics, and microwave scabbling. Technologies in the second group were considered to provide benefit to concrete decontamination, but with specific application, and include chemical extraction, chromographic strippable coatings (SensorCoat), laser ablation, and flashlamp. Technologies in the third group were removed from further consideration for demonstration because these technologies were essentially variations of baseline scabbling technologies and may be considered commercially available and thus beyond the scope of the project. 


\section{References}

Abel, K. H., D. E. Robertson, and C. W. Thomas. 1984. Residual Radionuclide Contamination Within and Around Nuclear Power Plants: Assessment of Origin, Distribution, Inventory and Decommissioning. PNL-5429, NUREG/CR-4289. Pacific Northwest Laboratory.

Abott, K. E. 1991. Plastic media blasting: The maturing of the technology. Presented at the 27th Annual Aerospace/Airline Plating \& Metals Finishing Forum \& Exposition, San Antonio, Texas, March 26-28, 1991.

Allen, R. P., H. W. Arrowsmith, and M. W. McCoy. 1981. New decontamination technologies for environmental applications. In proceedings of the workshop at Oak Ridge, Tennessee, December 4-5, 1981.

Allen, R. P. 1984. Overview of Nonchemical Decontamination Techniques. PNL-SA-12562. Pacific Northwest Laboratory.

Allen, R. P., K. J. Schneider, G. J. Knozek, and R. I. Smith. 1988. Decontamination technology assessment. In Proceedings of the International Topical Meeting on Nuclear and Hazardous Waste Management, Spectrum '88. American Nuclear Society, Inc., LaGrange Park, Illinois.

Anderson, K. G. 1980. Experiences in removing surfaces with explosives. In Proceedings of the Concrete Decontamination Workshop, May 28-29, PNL-SA-8855, ed. J. M. Halter, 99-108. Pacific Northwest Laboratory, Richland, Washington.

Archibald, K. E. 1995. Concrete Decontamination Scoping Tests (draft). Idaho National Engineering Laboratory, Idaho Falls, Idaho.

ANL. 1993. Manual for Implementing Residual Radioactive Material Guidelines Using RESRAD, Version 5.0. ANL/EAD/LD-2. Argonne National Laboratory.

AOU. 1994. Waste Recycling Workshop Proceedings. R. E. Bailey, A. F. Thomas, and M. A. Ries, eds. Alliance of Ohio Universities.

ASM. 1978. Metals Handbook: Surface Cleaning, Finishing, and Coating, Vol. 5. 9th ed. American Society for Metals, Metals Park, Ohio.

Ayers, A. J., ed. 1970. Ultrasonic cleaning. In Decontamination of Nuclear Reactors and Equipment, U.S. Atomic Energy Commission, Ronald Press, Hanford Operations. 
Barbier, M. M, and C. V. Chester. 1980. Decontamination of large horizontal concrete surfaces outdoors. In Proceedings of the Concrete Decontamination Workshop, September 1980, Nuclear Energy Services, Inc., Pacific Northwest Laboratory, Richland, Washington.

Bauer, R. G. 1989. Contaminated concrete scabbling at the Shippingport Station Decommissioning Project. Paper presented at the Annual Meeting of the American Nuclear Society, June 4-8, 1989, Atlanta, Georgia.

Bostick, W. D., S. A. Bush, G. C. Marsh, H. M. Henson, and W. D. Box. 1993. Electroosmotic Decontamination of Concrete. K/TCD-1054. Martin Marietta Energy Systems, Inc.

Bouchard and DMuhala. 1993. Chemical decontamination of large metal objects. Paper presented at the American Nuclear Society Global, Seattle, Washington, September 1993.

Brengle, R. G. 1979. The decontamination of concrete. Presented at the Decontamination and Decommissioning of Nuclear Facilities Conference, Sun Valley, Idaho.

Buckland, R.J., D. J. Kenoyer, and D. H. Preussner. 1993. INEL D\&D Long-Range Plan. Idaho National Engineering Laboratory, EG\&G, Idaho Falls, Idaho.

Caldwell, R. D., and R. M. Harper. 1975. Dismantling an alpha-contaminated facility. In Decontamination and Decommissioning of ERDA Facilities, proceedings of the first conference, Idaho Falls, Idaho, August 19-21, 1975, 295-302.

Cocke, D. L., and M. Y. A. Mollah. 1991. The chemistry and leaching mechanisms of hazardous substances in cementitous solidification/stabilization systems. In Proceedings of the Chemistry and Microstructure of Solidified Waste Forms Symposium, ACS National Meeting, New York City, August 25-30, 1991.

Combs, A. B., W. P. Davis, J. M. Garner, and J. R. Geichman. 1980. "A summary review of Mound Facility's experience in decontamination of concrete." In Proceedings of the Concrete Decontamination Workshop, May 28-29, PNL-SA-8855, ed. J. M. Halter, 179-191. Pacific Northwest Laboratory, Richland, Washington.

Conner, J. R. 1990. Chemical Fixation and Solidification of Hazardous Wastes. Van Nostrand Reinhold, New York. 
Cornelissen, H. A. W., and N. V. KEMA. 1990. Separation of contaminated concrete. In Decommissioning of Nuclear Installations, 1989 International Conference, ed. K. P. Flugrad, R. Bisci, B. Huber, and E. Skupinski, 731-737. Elsevier Applied Science, Barking, United Kingdom.

Costes, J. R., J. P. Gouchon, and M. Montjoie. 1988. Recent developments in gel and foam decontamination processes applied to decommissioning. In Proceedings of the Nuclear and Hazardous Waste Management International Topical Meeting, Spectrum '88, Pasco, Washington, September 11-15, 1988, 24-29. American Nuclear Society, LaGrange Park, Illinois.

Cox, E. J., and R. Garde. 1980. Decontamination of concrete surfaces at the Los Alamos scientific laboratory. In Proceedings of the Concrete Decontamination Workshop, May 28-29, PNL-SA-8855, ed. J. M. Halter, 109-123. Pacific Northwest Laboratory, Richland, Washington.

D\&D Tech. 1993a. Novel adaptions of conventional equipment for D\&D. $D \& D$ Technologies, 1(1):20.

D\&D Tech. 1993b. U.S. NRC's site decommissioning management plan. D\&D Technologies, 1(1):20.

D\&D Tech. 1993c. Sponge-jet decontamination at Aerojet. D\&D Technologies, 1(1):20.

Davenport, D., and T. Houk. 1995. X-705A Surface Decontamination Tests, Findings and Progress to Date. Internal correspondence written to Bill Schloesslin on January 4, 1995, Portsmouth Gaseous Diffusion Plant, Piketon, Ohio.

Deguchi, A., H. Fujihara, M. Makiguchi, J. Sakurai, S. Komura, H. Neki, J. Takagi, K. Chino, M. Ohura. 1992. Study on migration behavior of radioactive nuclides in concrete. In Proceedings of the International Topical Meeting on Nuclear and Hazardous Waste Management, Spectrum '92, 1359-1362. American Nuclear Society, LaGrange Park, Illinois.

Ebeling, W., B. Boedeker, K. Rose, K. H. Schaller, and B. Huber. 1984. Decontamination of concrete, with particular reference to flame scarfing. In Decommissioning of Nuclear Power Plants, European Conference, 161-176. Graham and Trotman Ltd., London, England.

EG\&G. 1986. Development of Criteria for Release of INEL Sites Following $D \& D$. EGG-2400. EG\&G, Idaho Falls, Idaho. 
Envirocare. 1989. Utah Department of Environmental Quality Division of Radiation Control Radioactive Material License No. UT2300249. Salt Lake City, Utah.

Envirocare. 1994. Waste Acceptance Criteria Summary. Envirocare, Salt Lake City, Utah.

Faillace, E. R., M. Nimmagadda, and C. Yu. 1994a. Derivation of Uranium Residual Radioactive Material Guidelines for the 4400 Piehl Road Site, Ottawa Lake, Michigan. ANL/EAD/TM-33. Argonne National Laboratory.

Faillace, E. R., M. Nimmagadda, and C. Yu. 1994b. Derivation of Uranium Residual Radioactive Material Guidelines for 13 Radionuclides Present in Operable Unit IV at Brookhaven National Laboratory, Upton, New York. ANL/EAD/TM-34. Argonne National Laboratory.

Faillace, E. R., M. Nimmagadda, and C. Yu. 1995. Derivation of Guidelines for Uranium Residual Radioactive Material in Soil at the Former Associate Aircraft Tool and Manufacturing Company Site, Fairfield, Ohio. ANL/EAD/TM-37. Argonne National Laboratory, Environmental Assessment division, Argonne, Illinois.

Foster, C. A. 1983. Solid deuterium centrifuge pellet injector. Journal of Vacuum Science and Technology, Al(2):952-958.

Foster, C. A. 1991. Surface impact cleaning by high-speed cryogenic pellets. In Second International Workshop on Solvent Substitution, Phoenix, Arizona, December 10-13, 1991.

Francis, C. W., A. J. Mattus, L. L. Farr, M. P. Elless, and S. Y. Lee. 1992. Selective Leaching of Uranium Contaminated Soils: Progress Report 1. ORNL/TM-12177. Oak Ridge National Laboratory, Oak Ridge, Tennessee.

Francis, C. W. 1993. Carbonate and Citrate Based Selectives Leaching of Uranium Contaminated Soils. ORNL-6782. Oak Ridge National Laboratory, Oak Ridge, Tennessee.

Francis, C. W., J. H. Wilson, and M. R. Ally. 1995. The Use of Carbonate/Bicarbonate Lixiviants to Extract Uranium from Uranium Contamination Soils (draft). Oak Ridge National Laboratory, Oak Ridge, Tennessee.

Freiwald, D. 1994. Laser Ablation of Contamination from Concrete and Metal Surfaces. Research by $F 2$ Associates, Albuquerque, New Mexico. 
Glasser, F. P. 1991. Chemistry of cement-solidified waste forms. In Proceedings of the Chemistry and Microstructure of Solidified Waste Forms Symposium, ACS National Meeting, New York City, August 25-30, 1991.

Goldfard, V. 1993. Concrete Decontamination by Electrohydraulic Scabbling (EHS). Research in progress by Textron, Inc., Everett, Maryland, 1993-1995.

Halter, J. M., R. G. Sullivan, and J. L. Bevan. 1982. Surface Concrete Decontamination Equipment Developed by Pacific Northwest Laboratory. PNL-4029. Pacific Northwest Laboratory, Richland, Washington.

Harris, J. M., J. R. Miller, R. S. Freeze, and J. H. Walter. 1982. Foam process for application of decontaminating agents. From the International Conference on Decontamination of Nuclear Facilities, Niagara Falls, Canada, September 19, 1982.

Harris, M. T., and O. A. Basaran. 1993. Capillary electrohydrostatics of conducting drops hanging from a nozzle in an electric field. Journal of Colloid and Interface Science, 161:389.

Hollis, J. R. 1983. Environmental Progress, 2:7.

IAEA. 1989. Cleanup of Large Areas Contaminated as a Result of a Nuclear Accident. Technical Report 300. International Atomic Energy Agency.

INEL. 1993. Idaho National Engineering Laboratory Waste Area Groups 1-7 and 10 Technology Logic Diagram. Vol. I, II, and III. EGG-WTD-10784. Idaho National Engineering Laboratory, EG\&G Idaho, Idaho Falls, Idaho.

INEL. 1994. Idaho National Engineering Laboratory Decontamination and Decommissioning Technology Logic Diagram. EGG-WTD-11104. EG\&G, Idaho Falls, Idaho.

Irving, B. A. 1980. Three Mile Island concrete decontamination experience. In Proceedings of the Concrete Decontamination Workshop, May 28-29, PNL-SA-8855, ed. J. M. Halter, 169-178. Pacific Northwest Laboratory, Richland, Washington.

Katayama, Y. B., L. K. Holton, Jr., and R. M. Gale. 1989. 324 and 325 Building Hot Cell Cleanout Program: Air Lock Cover Block Refurbishment. PNL-6898, UC-511. Pacific Northwest Laboratory, Richland, Washington.

Kaufmann, J., T. Luethi, A. Flisch, and J. Link. 1992. First results from the measurement of the distribution of water in building concrete by means of MRI and X-ray computer tomography. Presented at DGZfP Annual Meeting, Innovative Nondestructive Testing, a Challenge to All Sectors of Industry, April 27-29, 1992, Fulda, Germany. 
Kepner, C. H., and B. B. Tregor. 1973. The Rational Manager: A Systematic Approach to Problem Solving and Decision Making. Princeton Research Press, Princeton, New Jersey.

Laguardia, L. S. 1980. Concrete decontamination and demolition methods. In Proceedings of the Concrete Decontamination Workshop, September 1980. Nuclear Energy Services, Inc., Pacific Northwest Laboratory, Richland, Washington.

Li, W., M. A. Ebadian, T. L. White, and R. G. Grubb. 1992a. Heat transfer with a radiation contaminated slab applying a microwave heating technique. Journal of Heat Transfer, Transactions of the ASME, 155(1):42-50.

$\mathrm{Li}, \mathrm{W}$, et al. 1992b. Heat and mass transfer in a contaminated, porous concrete slab subjected to microwave heating. Presented at the 1992 Annual Winter Meeting of ASME, Anaheim, California, November 25 - December 2, 1992.

Lomasney, H. L. 1993. Electrokinetic Decontamination of Concrete. Research by Isotron Corporation, New Orleans, Louisiana.

Mandry, G. J., and R. W. Grisham. 1994. Decontamination Project for Cell G of the Metal Recovery Facility at Oak Ridge National Laboratory, Oak Ridge, Tennessee. ORNL/ER-219. Oak Ridge National Laboratory, Oak Ridge, Tennessee.

METC. 1994a. Decontamination and Recycle of Concrete. Technology Development Data Sheet. DE-AC21-93MC30166. Morgantown Energy Technology Center.

METC. 1994b. Concrete Decontamination by Electro-Hydraulic Scabbling. Technology Development Data Sheet. DE-AC21-93MC30164. Morgantown Energy Technology Center.

Morgan, I. L., and V. P. Gilbert. 1994. Testing of Non-Destructive Concrete Decontamination Techniques for the Solar Basins at the Hanford Site (draft). Oak Ridge National Laboratory, Oak Ridge, Tennessee.

Murphie, W. E. 1992. Decommissioning of radioactive facilities. In Proceedings of the Institution of Mechanical Engineers International Conference, February 17-19, 1992, London, United Kingdom, 9-16.

Neiswander, D. 1995. Personal and written communication to Kathryn Dickerson, Oak Ridge National Laboratory, Oak Ridge, Tennessee. (Joella - Dave Neiswander works at K-25 for CET [the Center for Environmental Technology]). 
Nimmagadda, M. R., E. Faillace, and C. Yu. 1994. Derivation of Uranium Residual Radioactive Material Guidelines for the Former Alba Craft Laboratory Site, Oxford, Ohio. ANL/EAD/TM-9. Argonne National Laboratory.

Nimmagadda, M. R. et al. 1995. Derivation of Guidelines for Uranium Residual Radioactive Material in Soil at the Former Baker Brothers, Inc. Site, Toledo, Ohio (draft). Argonne National Laboratory, Environmental Assessment Division, Argonne, Illinois.

Nutek. 1977. Chelant Mixture Regeneration with Strong Acid Cation and Weak Base Anion Resin Mixtures. Nutek Canada Limited and Prime Energy Systems, Ltd., Downsview Ontario, Canada.

Oak Ridge K-25 Site. 1993. Oak Ridge K-25 Site Technology Logic Diagram. Part A: Characterization, Decontamination, Dismantlement, Vol. 3. K-2073-Vol.3A. Oak Ridge K-25 Site, Oak Ridge, Tennessee.

ORNL. 1993. Oak Ridge National Laboratory Technology Logic Diagram. Part A: Decontamination and Decommissioning, Vol. 1 and 2. ORNL/M-2751/Pt. A. Oak Ridge National Laboratory, Oak Ridge, Tennessee.

Paladino, J., and P. Longsworth. 1995. A Common Framework for Managing Technology Development in DOE's Environmental Cleanup Program (draft). Used with permission. Office of Technology Development, Office of Environmental Management, U. S. Department of Energy.

Pang, H. M., D. Baldwin, and M. C. Edelson. 1992a. Macroscopic surface cleaning using a high repetition rate ultraviolet laser. In Proceedings of the IEEE Lasers and ElectroOptics Society (LEOS '92), Hynes Convention Center, Boston, November 16-19, 1992, 150.

Pang, H. M., R. J. Lipert, Y. M. Hamrick, S. Bayrakal, and K. Gaul. 1992b. Laser decontamination: A new strategy for facility decommissioning. In Proceedings of the International Topical Meeting on Nuclear and Waste Management, SPECTRUM '92, Boise, Idaho, August 23 and 27, 1992, 1335.

Parrott, J. R., Sr. 1980. The decontamination of concrete surfaces in building 3019, Oak Ridge National Laboratory. In Proceedings of the Concrete Decontamination Workshop, May 28-29, PNL-SA-8855, ed. J. M. Halter, 151-168. Pacific Northwest Laboratory, Richland, Washington.

Peterson, K. D., J. F. McGlynn, and W. N. Rankin. 1991. Foam as a decon waste minimization tool. In the proceedings of the Symposium on Nuclear Waste Management, Cincinnati, Ohio, April 28-May 2, 1991. 
Ramachandran, N. 1992. Methodologies used, constraints imposed, and lessons learned in the removal of radioactively contaminated concrete slab and subslab soil at the Elza Gate Site. In Waste Management '92: Working Towards a Cleaner Environment, Vol 1., Proceedings of a Symposium, Tucson, Arizona, March 1-5, ed. R. G. Post.

Ring, J. 1994. The evolution and status of ANSI N13.12, "Surface Radioactivity Guides for . Materials, Equipment, and Facilities to be Released for Uncontrolled Use." In Proceedings of Managing Radioactive and Mixed Wastes, Health Physics Society 27th Midyear Topical Meeting, Albany, New York, February 13-16, ed. NENY, 217-222. Chapter Health Physics Society, Albany, New York.

Roy, D. M. 1989. Relationships between permeability, porosity, diffusion, and microstructures of cement pastes, mortar, and concrete at different temperatures. In Proceedings 137 of the Material Research Society Symposium, 179-189.

Roy, D. M., and B. E. Scheetz. 1991. The chemistry of cementitious systems for waste management: The Penn State experience. In Proceedings of the Chemistry and Microstructure of Solidified Waste Forms Symposium, ACS National Meeting, New York City, August 25-30, 1991.

Siegrist, R. L., M. J. Morris, T. L. Donaldson, A. V. Palumbo, S. E. Herbes, R. A. Jenkins, C. M. Morrissey, and M. T. Harris. 1993. X-23IB Technology Demonstration for In Situ Treatment of Contaminated Soil: Technology Evaluation and Summary. ORNL/TM012257. Oak Ridge National Laboratory, Oak Ridge, Tennessee.

Simmons, M. 1994. Decontamination of radioactive concrete: A permanent solution that's RCRA friendly. Radwaste, 1:25-29.

Smith, D. L. 1980. Explosive demolition of activated concrete. In Proceedings of the Concrete Decontamination Workshop, May 28-29, PNL-SA-8855, ed. J. M. Halter, 137-149. Pacific Northwest Laboratory, Richland, Washington.

Swan, T., M. G. Segal, W. J. Williams, and M. E. Pick. 1987. LOMI Decontamination Reagents and Related Preoxidation Processes. EPRI-NP-5522M, Research Project 1329-1. Electric Power Research Institute, Palo Alto, California.

Troxell, G. E., E. D. Harmer, and J. W. Kelly. 1956. Composition and Properties of Concrete. 2nd ed. McGraw-Hill, New York.

TTI Engineering. 1991. Report on Nondestructive Cleaning Decontamination Facility at Surry Power Station. November 1990. Viewgraphs from seminar held March 22, 1991. 
U.S. AEC. 1974. Termination of Operating Licenses for Nuclear Reactors, Regulatory Guide 1.86. U.S. Atomic Energy Commission, Washington D.C.

U.S. DOE. 1988. Radioactive Waste Management. DOE Order 5820.2A. U.S. Department of Energy.

U.S. DOE. 1989. A Manual for Implementing Residual Radioactive Material Guidelines, $A$ Supplement to the U.S. Department of Energy Guidelines for Residual Radioactive Material at FUSRAP and SFMP Sites. DOE/CH-8901. U.S. Department of Energy.

U.S. DOE. 1990. Radiation Protection of the Public and Environment. DOE Order 5400.5. U.S. Department of Energy.

U.S. DOE. 1991. Decontamination and Decommissioning Integrated Demonstration Strategy (draft). U.S. Department of Energy.

U.S. DOE. 1992. Radiological Control Manual. DOE/EH-0256T. U.S. Department of Energy, Washington, D.C.

U.S. DOE. 1992a. Environmental Implementation Guide for Radiological Survey Procedures, (draft). U.S. Department of Energy, Washington D.C.

U.S. DOE. 1993a. Decontamination and Decommissioning Technology Assessment, Environmental Restoration Program. DOE/OR-1051. U.S. Department of Energy.

U.S. DOE. 1993b. Decommissioning Handbook. Prepared for the U.S. Department of Energy by Ebasco Services, Inc., Oak Ridge, Tennessee.

U.S. DOE. 1994a. Technical Program Plan for the Transitioning, Decommissioning, and Final Disposition Focus Area. Office of Technology Development, Office of Environmental Restoration and Waste Management, U.S. Department of Energy.

U.S. DOE. 1994b. Surplus Facility Inventory and Assessment Project. Office of Facility Transition and Management (EM-60), U.S. Department of Energy, Washington, D.C.

U.S. EPA. 1993a. Radiation Site Cleanup Regulation; Advanced Notice of Proposed Rulemaking (40 CFR 196). Federal Register, 58:54474.

U.S. EPA. 1993b. Issues Paper on Radiation Site Cleanup Regulations. EPA/402/ R-93/084. U.S. Environmental Protection Agency.

U.S. NRC. 1981. Disposal or On-site Storage of Thorium or Uranium from Past Operations. Nuclear Regulatory Commission. Federal Register, 46:52061. 
U.S. NRC. 1983. Termination of Byproduct, Source or Special Nuclear Materials Licenses. Policy and Guidance Directive FC 83-23. Nuclear Regulatory Commission.

U.S. NRC. 1992. Residual Radioactive Contamination from Decommissioning: Technical Basis for Translating Contamination Levels to Annual Total Effective Dose Equivalent. Final Report. NUREG/CR-5512. U.S. Nuclear Regulatory Commission.

U.S. NRC. 1994a. Generic Environmental Impact Statement in Support of Rulemaking on Radiological Criteria for Decommissioning of NRC-Licensed Facilities (draft). NUREG-1496, Vol. 2. U.S. Nuclear Regulatory Commission.

U.S. NRC. 1994b. Radiological Criteria for Decommissioning; Proposed Rule. Federal Register, 59(161):43200-43232.

Vig, J. R. 1990. UV/ozone cleaning of surfaces, semiconductor cleaning technology. Electrochemical Society Proceedings, 90(9):105-113.

Wahlen, R. K. 1980. Restoration of an irradiated fuel storage facility. In Proceedings of the Concrete Decontamination Workshop, May 28-29, PNL-SA-8855, ed. J. M. Halter, 125-135. Pacific Northwest Laboratory, Richland, Washington.

Washburn, E. W. 1921. The dynamics of capillary flow. Physical Review, 17:273.

White, T. L., R. G. Grubb, L. P. Pugh, D. Foster, and W. D. Box. 1992. Removal of contaminated concrete surfaces by microwave heating: Phase I results. Paper presented at Waste Management 92, March 1-5, 1992, Tucson, Arizona.

Yasunaka, $\mathrm{H}$. et al. 1987. Microwave decontaminator for concrete surface decontamination in IPDR. In Proceedings of the International Decommissioning Symposium, October 48, 1987, 109-115. 


\section{SELECTED BIBLIOGRAPHY}

Bargagliotti, A., L. Caprile, F. Piana, and E. Tolle. 1986. Plasma Arc and Thermal Lance Techniques for Cutting Concrete and Steel. EUR-10402. Commission of the European Communities, Luxembourg.

Berger, J. D. 1992. Manual for Conducting Radiological Surveys in Support of License Termination (draft). NUREG/CR-5849. Oak Ridge Associated Universities, Oak Ridge, Tennessee.

Boing, L. E., D. R. Henley, W. J. Manion, and J. W. Gordon. 1991. An evaluation of alternative reactor vessel cutting technologies for the decommissioning of the experimental boiling water reactor at Argonne National Laboratory. In Proceeding of Environmental Remediation '91: Cleaning Up the Environment for the 21st Century, Pasco, Washington, Sept. 8-11, 1991, ed. D. E. Wood, 345-350.

Caldwell, R. D., and R. M. Harper. 1975. Dismantling an alpha-contaminated facility. In Decontamination and Decommissioning of ERDA Facilities, proceedings of the first conference, Idaho Falls, Idaho, August 19-21, 1975, 518.

Cannon, N. S., and D. J. Flesher. 1993. Lasers for the radioactive decontamination of concrete. Presented at the International Conference of Lasers and Applications, Lake Tahoe, Nevada, December 6-10, 1993.

Collins, E. D., W. D. Box, H. W. Godbee, and T. C. Scott. 1988. Analysis of Data From Leaching Concrete Samples Taken from the TMI-2 Reactor Building Basement. Oak Ridge National Laboratory, Oak Ridge, Tennessee.

Commission of the European Communities, Directorate - General for Science, Research and Development Joint Research Center. 1991. EC programme on decommissioning of nuclear installations. In Decontamination and Decommissioning of Nuclear Facilities, Phase II. Second Research Coordination Meeting, Coordinated Research Program of the International Atomic Energy Agency.

Daugherty, H. F., R. Keel, J. M. Pope, I. M. Leonard, and E. J. Mayer. 1986. Decontamination and decommissioning of the West Valley Preprocessing Plant. In Proceedings, International Meeting on Low, Intermediate and High Level Waste Management - Decontamination and Decommissioning, Spectrum '86, 1253-1293. American Nuclear Society, Niagara Falls, New York. 
Hanulik, J., and D. W. T. Rippin. 1992. Chemical decontamination for decommissioning with application of DECOHA technology on metal, concrete and brickwork. In Nuclear Decom '92: Decommissioning of Radioactive Facilities, International Conference, 105-112. Mechanical Engineering Publications Ltd., London.

Harris, M. T., and C. H. Byers. 1989. An Orthogonal Co-Location Approach to Modeling Multicomponent Adsorption in Carbon Beds. ORNL/TM-10734. Oak Ridge National Laboratory, Oak Ridge, Tennessee.

ICS. 1986. Concrete demolition by hydrojetting. Indian Concrete Journal, 60(9):222-223.

Kickhus, K. J. 1992. Characterization and Decision Analysis for the Old Hot Laundry Facility (CFA-669). EGG-WM-10034.

Lynch, T. W., J. M Halter, R. G. Sullivan, and A. J. Currier. 1980. Diamond blade grinding as a means for removing surface contamination from concrete. In Proceedings of the Concrete Decontamination Workshop, PNL-SA-8855, 55-61. Pacific Northwest Laboratory, Richland, Washington.

Pietsch, E. H. E. 1970. "Uranium, General Properties, Criticality." In Gmelin Hondbook of Inorganic Chemistry Supplement Volume A6. Springer-Verlag, Berlin.

Ramsey, B. A. 1993. Peroxyborate as a decontamination agent. In Waste Management '93: Working Towards a Cleaner Environment, Tucson, Arizona, Feb. 28 - March 4, 1993, ed. R. G. Post, 1347-1350, Volume 2.

Smith, D. L. 1992. D\&D Plan for CFA-669 Hot Laundry. EGG-WM-10125.

Tuttle, R. J., W. D. Kittinger, C. C. Conners, and J. P. Page. 1984. Successful control measures for hazardous materials in decommissioning nuclear facilities. In Proceedings of an American Nuclear Society Annual Meeting, 65-66.

U.S. DOE. 1987. Real Property and Site Development Planning. DOE Order 4300.1B. U.S. Department of Energy.

U.S. DOE. 1993. Radiation Protection of the Public and the Environment; Proposed Rule (10 CFR 834). Federal Register, 58(56):16268-16322. U.S. Department of Energy.

U.S. EPA. 1991. National Primary Drinking Water Regulations; Radionuclides; Proposed Rule (40 CFR 161). Federal Register, 56:33050. U.S. Environmental Protection Agency. 
U.S. NRC. 1992. Residual Radioactive Contamination from Decommissioning: Technical Basis for Translating Contamination Levels to Annual Total Effective Dose Equivalent. Final Report. NUREG/CR-5512. U.S. Nuclear Regulatory Commission.

Weichselgartner, H. 1990. Development of decontamination foil. In Decommissioning and Demolition 1990: Decommissioning Offshore, Onshore Demolition and Nuclear Works, 2nd International Conference, ed. I. L. Whyte, 218-224. Thomas Telford Limited, London, United Kingdom.

Wing, J. F., M. E. Mitchell, and J. E Behrend. 1984. Handling and treatment of low-level wastes from gaseous diffusion plants in the United States of America. In Radioactive Waste Management, Vol. 2, proceedings of an international conference held by IAEA in Seattle, Washington, May 16-20, 1983. 


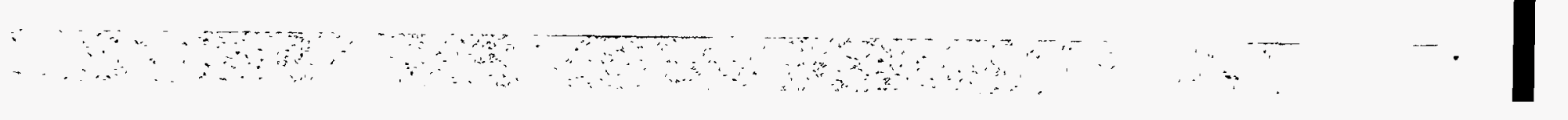




\section{Index of Candidate Technologies for Concrete Decontamination}

Biological Decontamination Technology

Biological Decontamination (Microbial-Influenced Degradation) $\ldots \ldots \ldots \ldots \ldots$ 3-4 Chemical Treatment Technologies

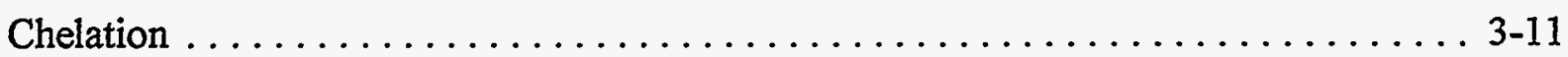

Chemical Foams . . . . . . . . . . . . .

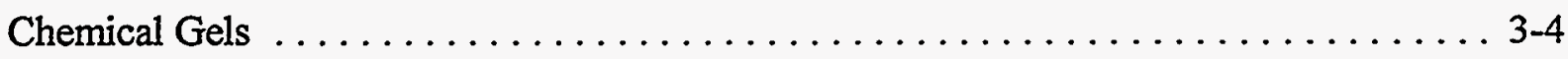

Chromographic Strippable Coatings (SensorCoat) $\ldots \ldots \ldots \ldots \ldots \ldots \ldots \ldots \ldots \ldots .5$

Decontamination and Recycle of Concrete . . . . . . . . . . . . . . . . .

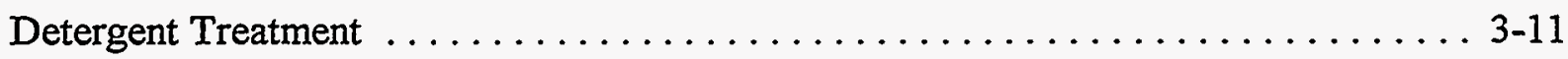

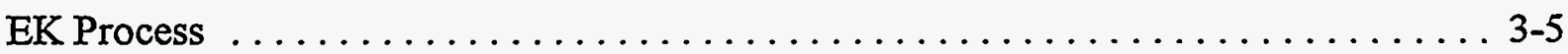

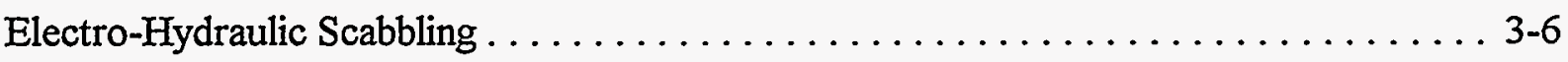

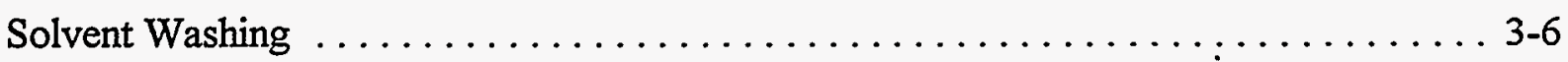

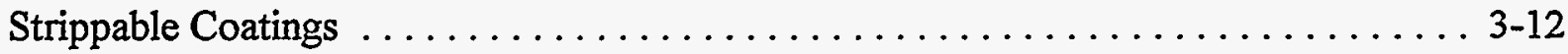

Mechanical Surface Removal Technologies

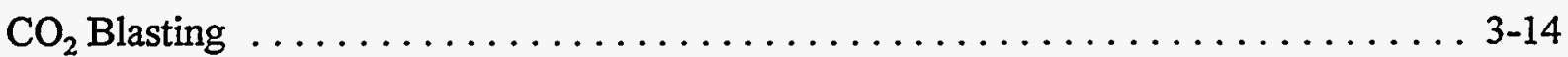

Compressed-Air Cryogenic $\mathrm{CO}_{2}$ Pellet Blasting $\ldots \ldots \ldots \ldots \ldots \ldots \ldots \ldots \ldots \ldots \ldots \ldots \ldots$

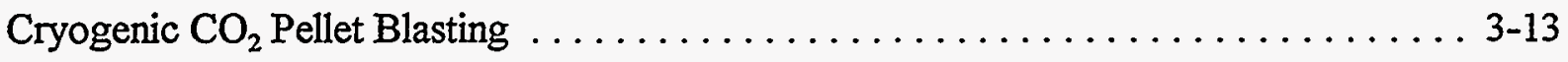

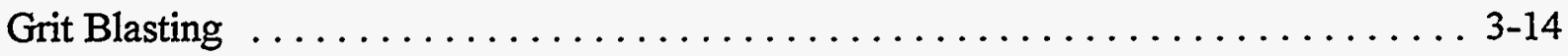

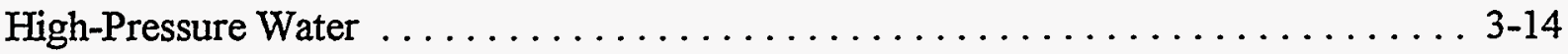

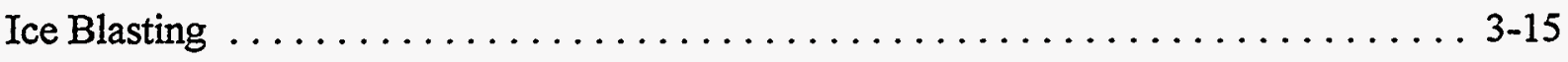

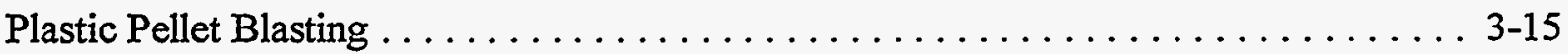

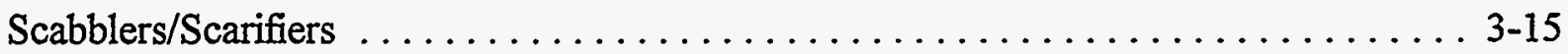

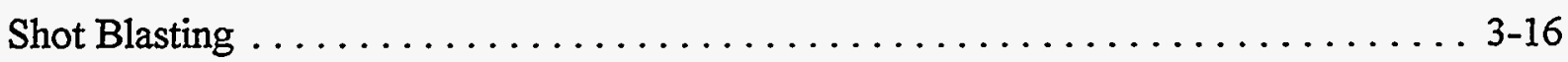

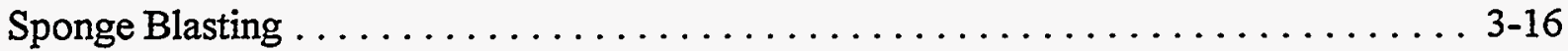

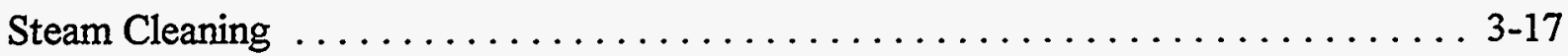




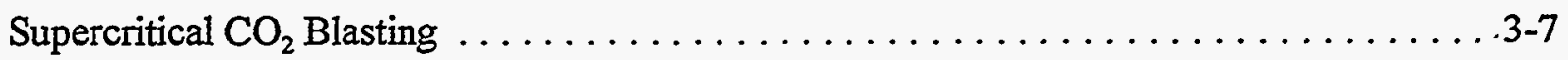

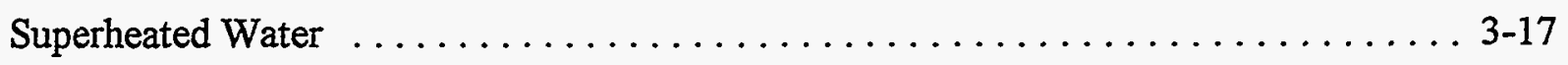

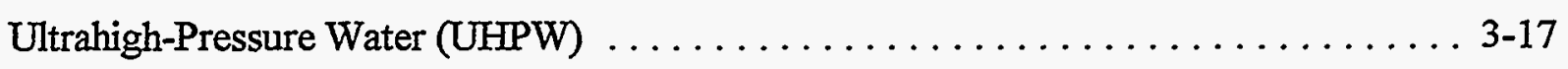

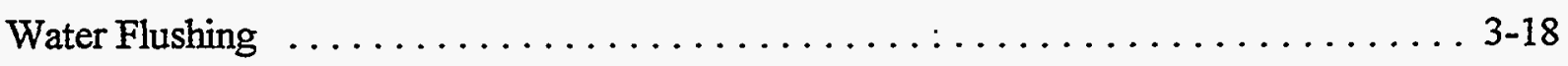

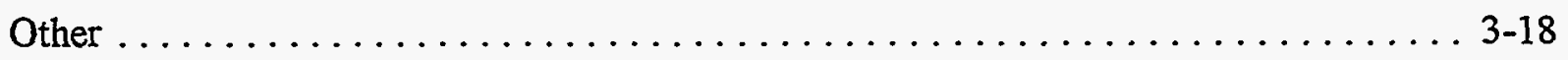

Thermal Removal Technologies

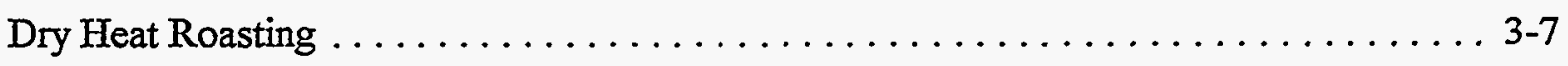

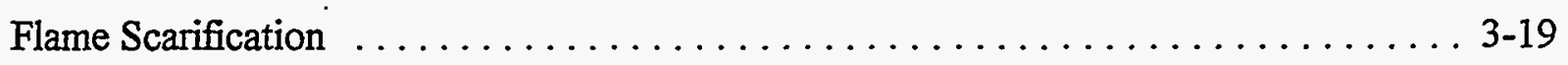

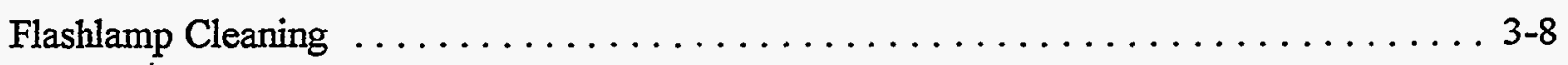

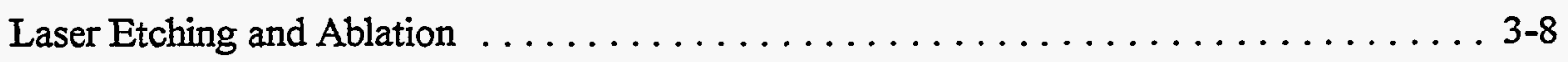

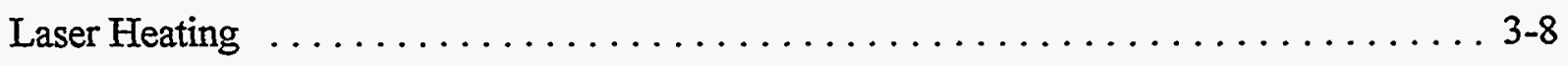

Microwave Scabbling .....................

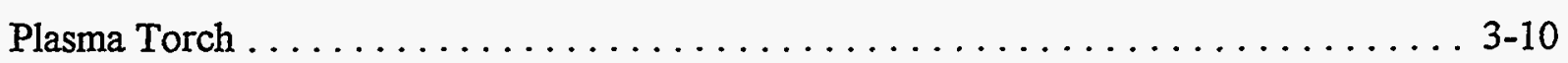


APPENDIX A

SITE EVALUATIONS 


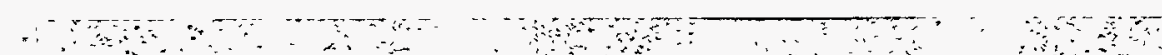




\section{INTRODUCTION}

Appendix A contains evaluations of the nature and extent of concrete contamination at $\mathrm{DOE}$ facilities. Information in the evaluations was obtained from telephone interviews with facility personnel, references received from facility contacts, documents found through a data base literature search, and written responses to an interview form. The interview form used to query D\&D representatives at the DOE sites is shown as Fig. A-1. Table A-1 is a summary of the sites contacted.

Forty-five DOE installations were contacted for information about concrete D\&D specific to each facility. Table A-2 is a summary of the information received from the sites. Typically, facilities with the largest volumes of all types of contamination had undergone more D\&D and had used more diverse D\&D technologies. ORR, INEL, HANF, and SRS, for example, had each tried many conventional technologies available. Some locations were unable to provide information for the survey because D\&D programs were not sufficiently developed. Other facilities had not yet begun pre-D\&D site-characterization studies, usually because the sites were still active. The remainder either had no contaminated concrete or had completed D\&D at some time in the past. The following installations are not included in the survey results.

Hallam Nuclear Power Facility: D\&D was completed in 1969 or 1970. Contaminants are activated metals. The reactor and associated buildings were filled with concrete, and a cover of plate steel was welded to the top of the reactor. The reactor and remaining structures were entombed rather than remediated.

Inhalation Toxicology Research Institute: Contaminants are ${ }^{90} \mathrm{Sr},{ }^{238} \mathrm{Pu},{ }^{239} \mathrm{Pu}$, and ${ }^{241} \mathrm{Am}$. Depth of contamination in the concrete is approximately $1 / 4$ in. Concrete decontamination at the waste storage area consists of breaking up entire slabs and hauling the rubble to NTS.

Lawrence Livermore: No concrete decontamination is planned.

New Brunswick Lab: No contaminated concrete exists.

Pacific Northwest Laboratory: This site is included with HANF in the survey.

Pantex: There is currently no concrete D\&D and none is planned.

Pinellas Plant: Main contaminant is tritium. There has been no previous D\&D, hardly any characterization, and none is planned. The plant ceased production in September 1994, and shutdown operations will take approximately two years. The current plan is to sell the facility, in which case no D\&D would be performed. 
Princeton Plasma Physics Lab: Contaminants are activation products of copper, stainless steel, and titanium and some tritium. Princeton is a category III nuclear facility. Tokamat Fusion Test Reactor is scheduled for decommissioning at the end of September 1995. There has been no D\&D in the past and very little planned for the future.

Sandia National Laboratory: No D\&D is planned until FY96. Characterization has been delayed until EM-40 funding is available.

Shipping Port Station : This facility was decommissioned in 1978 . 


\section{A-3}

Accelerated Testing of Concrete Decontamination Methods at DOE Facilities

INTERVIEW FORM

Site: Address :

Contact:

Phone No: Date:

1. Site Information ( $D \& D$ problem definition, general site information):

2. Concrete contamination (significance of problem, locations, extent, volume, dimensions):

3. Contaminant characteristics (primary contaminants, physical characteristics):

4. Type of decontamination technologies selected or options under consideration, technology needs (especially any new technology under development, bench scale or pilot demonstrations):

Fig. A-1. Interview form. 
5. On-site/off-site disposal (location if known):

6. Cost and schedule for decontamination: (total cost, estimate of total treatment time, current status or projected start date, if known):

7. References available: (D\&D needs, $D \& D$ technologies, characterization data, feasibility studies, treatment plans, contacts):

8. Other information and lessons learned:

9. cleanup criteria:

10. ongoing technology demonstrations:

Fig. A-1. (continued). 
Table A-1. Summary of DOE sites and contacts

\begin{tabular}{|c|c|c|c|}
\hline Site & Contact & Telephone & Fax \\
\hline $\begin{array}{l}\text { Argonne National } \\
\text { Laboratory }\end{array}$ & Mike Coffey & $(708) 252-4315$ & $(708) 252-4007$ \\
\hline $\begin{array}{l}\text { Argonne National } \\
\text { Laboratory West }\end{array}$ & $\begin{array}{l}\text { Rick Riggs } \\
\text { Larry Harrison }\end{array}$ & $\begin{array}{l}(208) 533-7816 \\
(208) 533-7458\end{array}$ & $(208) 533-7711$ \\
\hline $\begin{array}{l}\text { Battelle Columbus } \\
\text { Laboratories }\end{array}$ & Ron Carlson & $(614) 424-7074$ & $(614) 424-3954$ \\
\hline $\begin{array}{l}\text { Brookhaven National } \\
\text { Laboratory }\end{array}$ & $\begin{array}{l}\text { Bob Litzke } \\
\text { Paul Kald }\end{array}$ & $\begin{array}{l}(516) 282-5689 \text { or } \\
(516) 282-2818 \\
(516) 282-7644\end{array}$ & \\
\hline $\begin{array}{l}\text { Energy Technology } \\
\text { Engineering Center }\end{array}$ & $\begin{array}{l}\text { Rod Meyers } \\
\text { Phil Horton } \\
\text { Phil Rutherford } \\
\text { Jim Barns }\end{array}$ & $\begin{array}{l}(818) 586-5400 \\
(818) 586-5384 \\
(818) 586-6140 \\
(818) 586-5766\end{array}$ & $(818) 586-5118$ \\
\hline $\begin{array}{l}\text { Fernald Environmental } \\
\text { Management Project }\end{array}$ & $\begin{array}{l}\text { Joe Boudreaux } \\
\text { Sue Madaris } \\
\text { Dick Martineit } \\
\text { Lorie Miller } \\
\text { Tom Vunak }\end{array}$ & $\begin{array}{l}(513) 738-9455 \\
(513) 870-8309 \\
(513) 648-6386 \\
(513) 738-9471 \\
(513) 738-6121\end{array}$ & \\
\hline $\begin{array}{l}\text { Formerly Utilized Sites } \\
\text { Remedial Action Project } \\
\text { (FUSRAP) }\end{array}$ & $\begin{array}{l}\text { Melissa Noe } \\
\text { Ron Kirk } \\
\text { Jim Kopotic } \\
\text { Dave Adler }\end{array}$ & $\begin{array}{l}(615) 241-3315 \\
(615) 576-7477 \\
(615) 576-9441 \\
(615) 576-9634\end{array}$ & $(615) 576-0956$ \\
\hline General Atomics & $\begin{array}{l}\text { George Bramblett } \\
\text { Alan Lewis }\end{array}$ & $\begin{array}{l}(619) 455-4220 \\
(619) 455-3510\end{array}$ & $(619) 455-3181$ \\
\hline $\begin{array}{l}\text { Grand Junction Projects } \\
\text { Office }\end{array}$ & Steve Corle & $(303) 248-6497$ & \\
\hline $\begin{array}{l}\text { Hallam Nuclear Power } \\
\text { Facility }\end{array}$ & $\begin{array}{l}\text { Jim DeFrain (Neb. } \\
\text { Dept. of Health) }\end{array}$ & $(402) 471-2168$ & \\
\hline Hanford Reservation & $\begin{array}{l}\text { Robert Egge } \\
\text { Mike Mihalik } \\
\text { Rich Hudson }\end{array}$ & $\begin{array}{l}(509) 373-2774 \\
(509) 373-1382 \\
(509) 372-1270\end{array}$ & $(509) 373-0726$ \\
\hline $\begin{array}{l}\text { Idaho National } \\
\text { Engineering Laboratory }\end{array}$ & $\begin{array}{l}\text { R.J. (Russ) Buckland } \\
\text { Don Harrison } \\
\text { Kip Archibald }\end{array}$ & $\begin{array}{l}(208) 526-9813 \\
(208) 526-7514\end{array}$ & \\
\hline $\begin{array}{l}\text { Idaho Chemicals } \\
\text { Processing Plant }\end{array}$ & Dennis Peterson & $(208) 526-7441$ & (208) 526-4775 \\
\hline K-25 Site & Ronnie K. McMahan & $(615) 576-9979$ & \\
\hline
\end{tabular}


Table A-1. (continued)

\begin{tabular}{|c|c|c|c|}
\hline Site & Contact & Telephone & Fax \\
\hline Kansas City Plant & Dave Brown & $(816) 997-4034$ & (816)997-5903 \\
\hline $\begin{array}{l}\text { Lawrence Berkeley } \\
\text { Laboratory }\end{array}$ & $\begin{array}{l}\text { Robert Fox } \\
\text { Roger Kloepping } \\
\text { Mike Schoonover }\end{array}$ & $\begin{array}{l}(510) 486-7327 \\
(510) 486-7608 \\
(510) 486-6424\end{array}$ & $(510) 486-5007$ \\
\hline $\begin{array}{l}\text { Los Alamos National } \\
\text { Laboratory }\end{array}$ & Miguel Salazar & $(505) 665-3056$ & \\
\hline Mound Plant & William P. Davis & $(513) 865-3513$ & $(513) 847-5263$ \\
\hline Nevada Test Site & $\begin{array}{l}\text { Janet Appenzeller-Wing } \\
\text { Laura Tryboski } \\
\text { (IT Corp.) }\end{array}$ & $\begin{array}{l}(702) 295-0461 \\
(702) 794-1712\end{array}$ & $(702) 295-1113$ \\
\hline $\begin{array}{l}\text { Oak Ridge Institute of } \\
\text { Science and Education }\end{array}$ & Chuck Scott & $(615) 576-3335$ & $(615) 576-7047$ \\
\hline $\begin{array}{l}\text { Oak Ridge National } \\
\text { Laboratory }\end{array}$ & Gary Person & $(615) 574-9686$ & \\
\hline $\begin{array}{l}\text { Pacific Northwest } \\
\text { Laboratory }\end{array}$ & $\begin{array}{l}\text { Jeff Serma } \\
\text { Glenn Hollenburg }\end{array}$ & $\begin{array}{l}(509) 376-4905 \\
(509) 376-5515\end{array}$ & $(509) 372-1861$ \\
\hline $\begin{array}{l}\text { Paducah Gaseous } \\
\text { Diffusion Plant }\end{array}$ & Steve Davis & $(502) 441-5066$ & $(502) 441-5064$ \\
\hline Pantex Plant & $\begin{array}{l}\text { Bob Houck } \\
\text { (D\&D manager for } \\
\text { Albuquerque Area } \\
\text { Office) }\end{array}$ & $(505) 845-4887$ & \\
\hline Pinellas Plant & Dave Ingle & $(813) 541-8943$ & \\
\hline $\begin{array}{l}\text { Portsmouth Gaseous } \\
\text { Diffusion Plant }\end{array}$ & $\begin{array}{l}\text { Bill Schloesslin } \\
\text { Doug Davenport }\end{array}$ & $\begin{array}{l}(614) 897-4374 \\
(614) 897-3261\end{array}$ & $(614) 897-3800$ \\
\hline $\begin{array}{l}\text { Princeton Plasma } \\
\text { Physics Lab }\end{array}$ & George Coward & $(609) 243-2767$ & \\
\hline RMI Titanium, Inc. & Scott Fultz & (216)993-2088 & \\
\hline $\begin{array}{l}\text { Rocky Flats } \\
\text { Environmental } \\
\text { Technology Site }\end{array}$ & $\begin{array}{l}\text { Chuck Reed } \\
\text { Dana Santi } \\
\text { Chuck Baldwin }\end{array}$ & $\begin{array}{l}(303) 966-3688 \\
(303) 966-4200 \\
(303) 966-4008\end{array}$ & (303)966-2982 \\
\hline $\begin{array}{l}\text { Rocky Mountain } \\
\text { Arsenal }\end{array}$ & $\begin{array}{l}\text { Wayne Sisk, Aberdeen } \\
\text { Proving Ground }\end{array}$ & $(410) 612-6851$ & $(410) 612-6836$ \\
\hline $\begin{array}{l}\text { Sandia National } \\
\text { Laboratories }\end{array}$ & $\begin{array}{l}\text { Tom Sanders } \\
\text { Warren Cox } \\
\text { David Miller }\end{array}$ & $\begin{array}{l}(505) 845-8542 \\
(505) 848-0411 \\
(505) 848-0460\end{array}$ & (505)848-0417 \\
\hline
\end{tabular}




\begin{tabular}{llll} 
Site & Contact & Telephone & Fax \\
\hline Savannah River Site & Bill Austin & $(803) 644-5056$ & \\
& Tom Butcher & $(803) 725-5810$ & $(803) 725-1660$ \\
& Rich Hanes & $(803) 725-5811$ & \\
& Ron Hinds & $(803) 725-5422$ & \\
& H.P. Olson & $(803) 644-5122$ & \\
& Bob Smith & $(803) 557-2662$ & \\
Stanford Linear & Maxine Stokly & $(415) 926-4460$ & $(415) 926-3030$ \\
Accelerator Center & & & \\
Weldon Spring Site & Ken Lawver & $(314) 441-8978$ & \\
Remedial Action Project & Neil DeYong & $(314) 441-8086$ & \\
& ext. 3120 & \\
West Valley & Dan Burke & $(716) 942-4248$ & \\
Demonstration Project & Dana Pezzimenti & $(716) 942-4321$ & \\
& Don Sawyer & $(716) 942-4333$ or & \\
& Peter Vlad & $(716) 942-4964$ & \\
& Susan Howell & $(716) 942-4809$ & \\
Y-12 Plant & Bruce Walton & $(615) 576-8260$ & $(615) 576-8777$ \\
& Mark Solenberger & $(615) 241-2695$ & \\
& & & \\
\hline
\end{tabular}


Table A.2. Summary of facilities, contaminants, and technologies

\begin{tabular}{|c|c|c|c|}
\hline Fancility and Site & Contaminant & Volume & D\&D Technology and Comments \\
\hline \multicolumn{4}{|c|}{ Argonne National Laboratory } \\
\hline CP-5 reactor facility & ${ }^{60} \mathrm{Co},{ }^{137} \mathrm{Cs}$, possibly some ${ }^{3} \mathrm{H}$ & $\begin{array}{l}\text { Containment structure: } \sim 1000 \mathrm{ft}^{2} \\
\text { up to } 1 / 4 \mathrm{in.} \text { deep. } \\
\text { Rod Storage Area: } \sim 400 \mathrm{n}^{2} \text { to a } \\
\text { depth of } 6 \text { to } 8 \mathrm{in} ; \text { if the storage } \\
\text { tubes have becn breached, localized } \\
\text { areas may be contaminated } 6 \text { in. } \\
\text { radially for the affected length of } \\
\text { the tube (up to } 16 \mathrm{ft} \text { decp). }\end{array}$ & $\begin{array}{l}\text { Technology demonstrations: } \\
\text { a demonstration was performed using a chemical concrete } \\
\text { decontamination compound (not specified). Overall, this technique } \\
\text { was rated unsatisfactory because the floor still contained } \\
\text { radionclivity above clean-up criteria. } \\
\text { Technologies under consideration: } \\
\text { not known; mechnnical demolition and abrading, scnbbling, } \\
\text { abrasive tooling, and pneumatic demolition have been used. } \\
\text { Teclnologies needed: not known. }\end{array}$ \\
\hline \multicolumn{4}{|c|}{ Batelle Columbus Laboratory } \\
\hline $\begin{array}{l}\text { King Avenue and West } \\
\text { Jefferson }\end{array}$ & $\begin{array}{l}\text { U. Th, some mixed fission } \\
\text { products }\end{array}$ & $\begin{array}{l}\text { Not kuown; as of January } 1995 \text {, about } \\
200,000 \mathrm{n}^{2} \text { had becn cleaned up. } \\
\text { Contamination deptl varies from } \\
1 / 16 \text { in. to } 5 \text { or } 6 \mathrm{in} \text {. }\end{array}$ & $\begin{array}{l}\text { Tcelmology demonstrations: none. } \\
\text { Teclmologies needed: none. } \\
\text { Teclnologies considered: nonc. D\&D personncl were directed to use } \\
\text { existing teclmologics. } \\
\text { Teclunology uscd: vacuun blasting and scabbling. }\end{array}$ \\
\hline \multicolumn{4}{|c|}{ Brookhaveu National Labor'atory } \\
\hline $\begin{array}{l}\text { Buildings } 444,445 \\
446,448\end{array}$ & Radioactive (not specified) & Nol known. & $\begin{array}{l}\text { D\&D technology has not been chosen; current projections are that } \\
\text { D\&D of the graphite reactor will not begin until } 2005 \text {. }\end{array}$ \\
\hline $\begin{array}{l}\text { Building } 811 \text { storage } \\
\text { tanks }\end{array}$ & ${ }^{3} \mathrm{H},{ }^{22} \mathrm{Na},{ }^{60} \mathrm{Co},{ }^{137} \mathrm{Cs},{ }^{21 !} \mathrm{Bi}$ & Not known. & \\
\hline Graphite reactor & $\begin{array}{l}\text { Uranium oxide, } \mathrm{Pu},{ }^{60} \mathrm{Co},{ }^{60} \mathrm{Fe} \text {, } \\
{ }^{131} \mathrm{Cs},{ }^{90} \mathrm{Sr}\end{array}$ & $9000 \mathrm{ft}^{3}$ & \\
\hline
\end{tabular}


Table A.2. (continued)

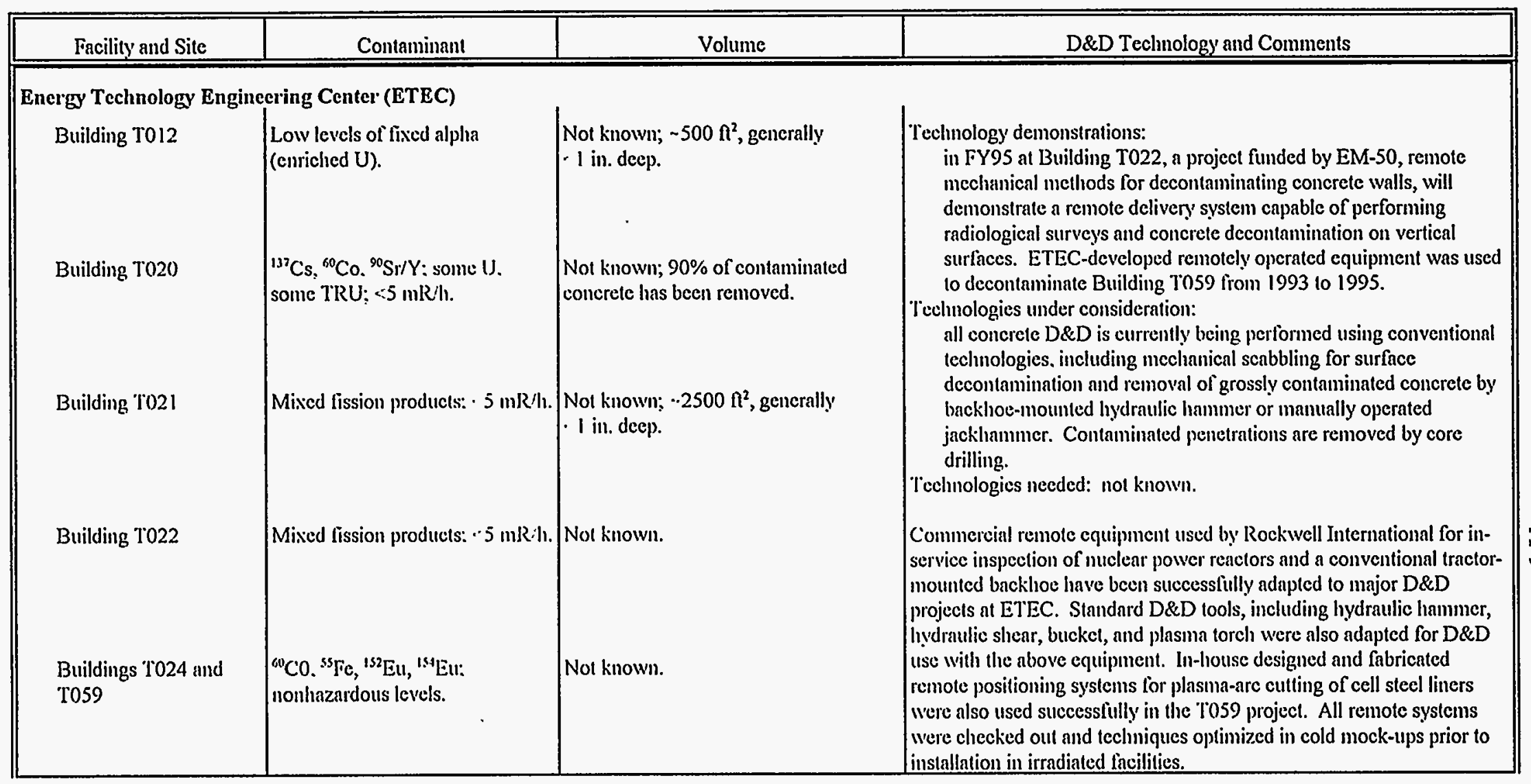


Table A.2. (continued)

\begin{tabular}{|c|c|c|c|}
\hline Facility and Site & Contaminant & Volume & D\&D Teclinology and Comments \\
\hline \multicolumn{4}{|c|}{ Feruald Environmental Management Project (FEMP) } \\
\hline $\begin{array}{l}\text { Operable Unil } 3 \text {. } \\
\text { K-65 silos (silos } 1 \\
\text { and 2) }\end{array}$ & U, Th & $3.3 \times 10^{6} \mathrm{ft}^{3}$ & $\begin{array}{l}\text { Teclunology demonstrations: } \\
\text { FEMP has been selected for a site demonstration of electro- } \\
\text { hydraulic scabbling (schedule unknown); facility is also under } \\
\text { consideration for hosting a demonstration of concrete surface } \\
\text { decontamination using laser ablation. } \\
\text { Technologies under consideration: } \\
\text { a variely of teclmologies will be used to decontaminate concrete. } \\
\text { The present approach is to allow the subcontractor to choose a } \\
\text { teclunology after providing performance specifications. Docu- } \\
\text { ments pertaining to treatability and feasibility studies of the site are } \\
\text { ised evalunte the selected technology to ensure that it is safe and } \\
\text { cost-effective. } \\
\text { Teclunologies nceded: not known. }\end{array}$ \\
\hline \multicolumn{4}{|c|}{ Grand Junction Projects Office } \\
\hline
\end{tabular}


Table A.2. (continued)

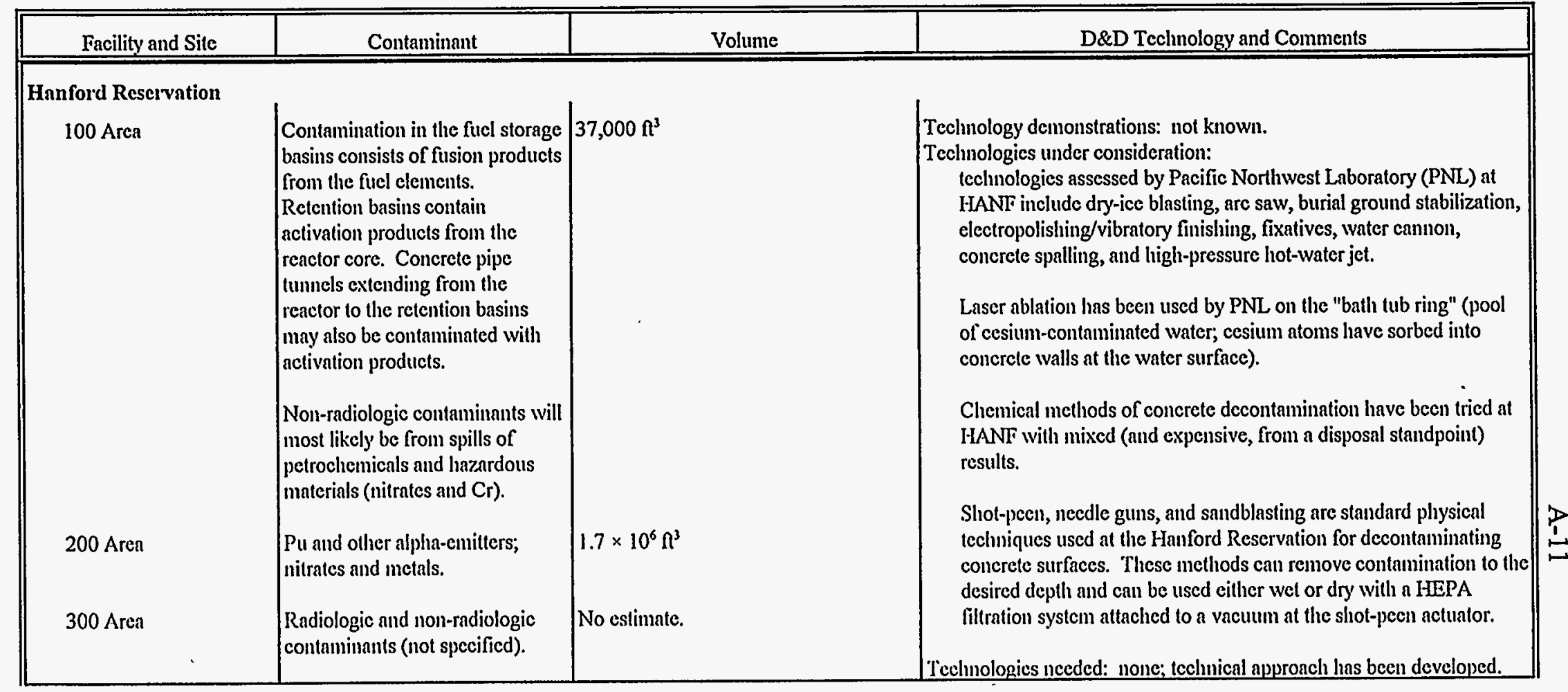


Table A.2. (continued)

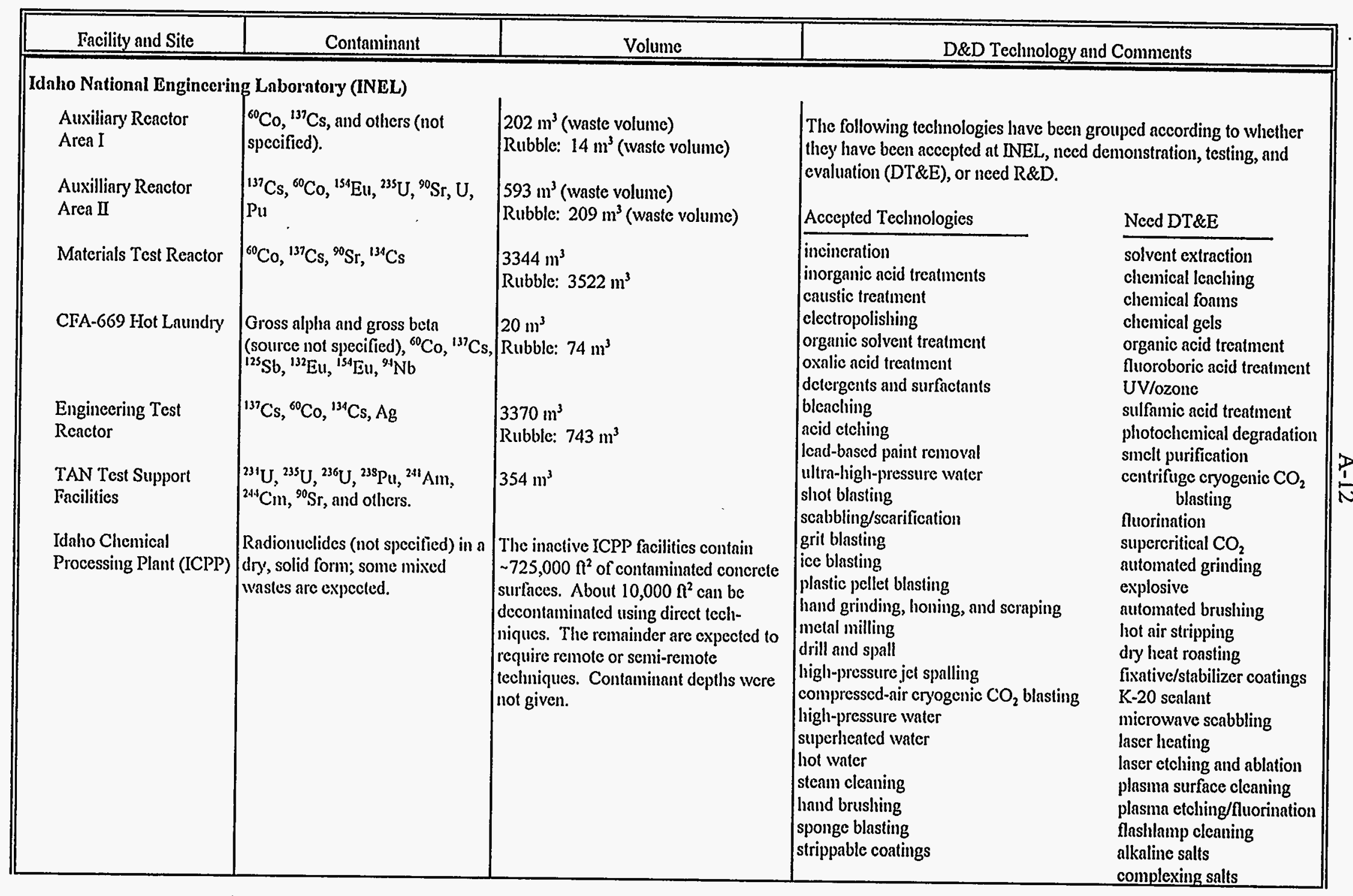


Table A.2. (continued)

\begin{tabular}{|c|c|c|c|c|}
\hline Facility and Sitc & Contaminant & Volume & \multicolumn{2}{|c|}{ D\&D Technology and Comments } \\
\hline \multicolumn{5}{|l|}{ INEL (cont.) } \\
\hline \multirow{2}{*}{$\begin{array}{l}\text { ICPP. Chloride } \\
\text { Removal System }\end{array}$} & \multirow[t]{2}{*}{ U. Pu. Sr. Ce. Co. Eu. Am } & \multirow[t]{2}{*}{ Not known. } & Accepled Technologies (cont.) & Need R\&D \\
\hline & & & $\begin{array}{l}\text { vacuuming (low pressure) } \\
\text { ultrasonic cleaning } \\
\text { llaming } \\
\text { turbulator } \\
\text { vibrating finishing } \\
\text { wet abrasive cleaning } \\
\end{array}$ & $\begin{array}{l}\text { biological } \\
\text { dry heat } \\
\text { catalytic extraction process } \\
\text { biological surlace cleaning } \\
\text { laser-activated chemistry } \\
\text { clectromigration } \\
\text { concrete milling } \\
\text { solvent washing } \\
\text { solvent washing to remove } \\
\text { organies } \\
\text { microbial degradation } \\
\text { plasma torcl }\end{array}$ \\
\hline \multicolumn{5}{|c|}{ Lawrence Berkeley Laboratory } \\
\hline Bciclac & 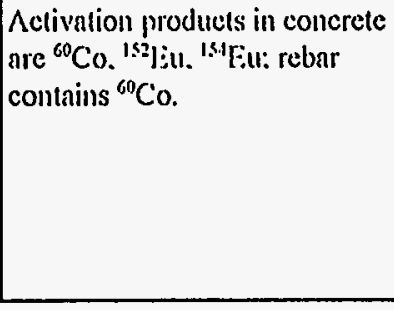 & Estimated at 500,000) $\mathrm{ll}^{3}$ & \multicolumn{2}{|c|}{$\begin{array}{l}\text { Technology demonstrations: none. } \\
\text { Technologies under consideration: } \\
\text { none, other than recycling and reuse. Concrete shipped to ORR } \\
\text { will be pulverized and reused as aggregate in new concrete for } \\
\text { wasle burial boxes. Rebar in the concrete will be cut and ground } \\
\text { into small "libers" and reintroduced into the matrix as a } \\
\text { strengthening material. } \\
\text { lechmologies needed: none. }\end{array}$} \\
\hline \multicolumn{5}{|c|}{ Los Alamos National Laboratory } \\
\hline $\begin{array}{l}\text { Various laboratories, } \\
\text { one reaclor, approxi- } \\
\text { mately } 40 \text { small } \\
\text { structures used for } \\
\text { explosives work }\end{array}$ & ${ }^{2.39} \mathrm{Pu},{ }^{235} \mathrm{U}$ & Estimated at $6000 \mathrm{yd}^{3}$ & \multicolumn{2}{|c|}{$\begin{array}{l}\text { Techmology demonstrations: not known. } \\
\text { Techmologies under consideration: } \\
\text { traditional mechanical scabbling is currently being used. Solvent, } \\
\text { microwave, and laser teclmologies are being examined but have not } \\
\text { been applied al the site. Waste minimization by crushing and } \\
\text { segregating the concrete is being seriously considered. } \\
\text { Technologies needed: not known. }\end{array}$} \\
\hline
\end{tabular}


Table A.2. (continued)

\begin{tabular}{|c|c|c|c|}
\hline Facility and Site & Contaminant & Volume & D\&D Tecluology and Comments \\
\hline \multicolumn{4}{|l|}{ Mound Plant } \\
\hline $\begin{array}{l}\text { Buildings WD, R, SW, } \\
\text { T, 21, 38, HH, Misc. }\end{array}$ & $\begin{array}{cl}\text { WD } & :{ }^{238} \mathrm{Pu},{ }^{3} \mathrm{H} \\
\mathrm{R} & :{ }^{238} \mathrm{Pu} \\
\mathrm{SW} & :{ }^{3} \mathrm{H} \\
\mathrm{T} & :{ }^{3} \mathrm{H} \\
21 & :{ }^{232} \mathrm{Th} \\
38 & :{ }^{238} \mathrm{Pu} \\
\text { HWH } & : \text { miscellaneous (not } \\
& \text { specified) } \\
\text { Misc. } & { }^{238} \mathrm{Pu},{ }^{3} \mathrm{H}\end{array}$ & $\begin{array}{l}\text { Total volume of rubble generated is } \\
\text { estimated at } 50,000 \text { to } 100,000 \mathrm{f}^{3} \\
\text { without waste-packaging volume. }\end{array}$ & $\begin{array}{l}\text { Technology demonstrations: } \\
\text { Envirommental and Extraction Techmologies (EET) is doing a pilot } \\
\text { test on a tiled-covered floor using their solvent extraction method. } \\
\text { Two of the three applications have been completed, } \\
\text { and the decontamination results have been good. A third, final } \\
\text { application will be performed after some bioassay requirements are } \\
\text { met. } \\
\text { Teclmologies under consideration: } \\
\text { For alpla emitters, acid leaching, removable paint, sandblasting, and } \\
\text { various mechanical methods of removal have been tricd. Overall, } \\
\text { the best approach (when detergents didn't work) has been the use of } \\
\text { an enclosed recycling abrasive blaster } \\
\text { Technologies needed: not known. }\end{array}$ \\
\hline \multicolumn{4}{|l|}{ Nevada Test Site } \\
\hline \multicolumn{4}{|c|}{ Onk Ridge National Laboratory (ORNL) } \\
\hline $\begin{array}{l}\text { Sixteen facilities } \\
\text { consisting of } 50 \text { separate } \\
\text { areas are currently in the } \\
\text { D\&D program }\end{array}$ & $\begin{array}{l}\text { Fission products, }{ }^{3} \mathrm{HI},{ }^{32} \mathrm{P},{ }^{60} \mathrm{Co} \\
{ }^{85} \mathrm{Kr},{ }^{90} \mathrm{Sr},{ }_{2}^{129} \mathrm{I},{ }^{137} \mathrm{Cs},{ }^{147} \mathrm{Pm},{ }^{153} \mathrm{Gd}, \\
{ }^{192} \mathrm{Ir},{ }^{233} \mathrm{U},{ }^{239} \mathrm{Pu},{ }^{244} \mathrm{Cm}, \mathrm{U}, \mathrm{Th}\end{array}$ & Not known. & $\begin{array}{l}\text { Technology demonstrations: not known. } \\
\text { Techunologies under consideration: not known. } \\
\text { Techmologics needed: } \\
\text { 1. more efficient concrete surface layer removal } \\
\text { 2. reduction of secondary waste from decontamination processes } \\
\text { 3. innovative systens for floor and wall decontamination } \\
\text { 4. decontamination of metals }(\mathrm{Ni}, \mathrm{Al}, \mathrm{Pb}, \mathrm{Hg}) \\
\text { 5. remote decontamination } \\
\text { 6. decontamination of rubble }\end{array}$ \\
\hline
\end{tabular}


Table A.2. (continued)

\begin{tabular}{|c|c|c|c|}
\hline Fancility and Site & Contaminant & Volume & D\&D Technology and Comments \\
\hline \multicolumn{4}{|c|}{ Onk Ridge Reservation (ORR) } \\
\hline K-25 & U: ${ }^{99} \mathrm{TC}$. TRU & $\begin{array}{l}16.7 \cdot 10^{6} \mathrm{n}^{2} \\
\text { Rubble: } 5 \cdot 10^{6} \mathrm{n}^{3}\end{array}$ & 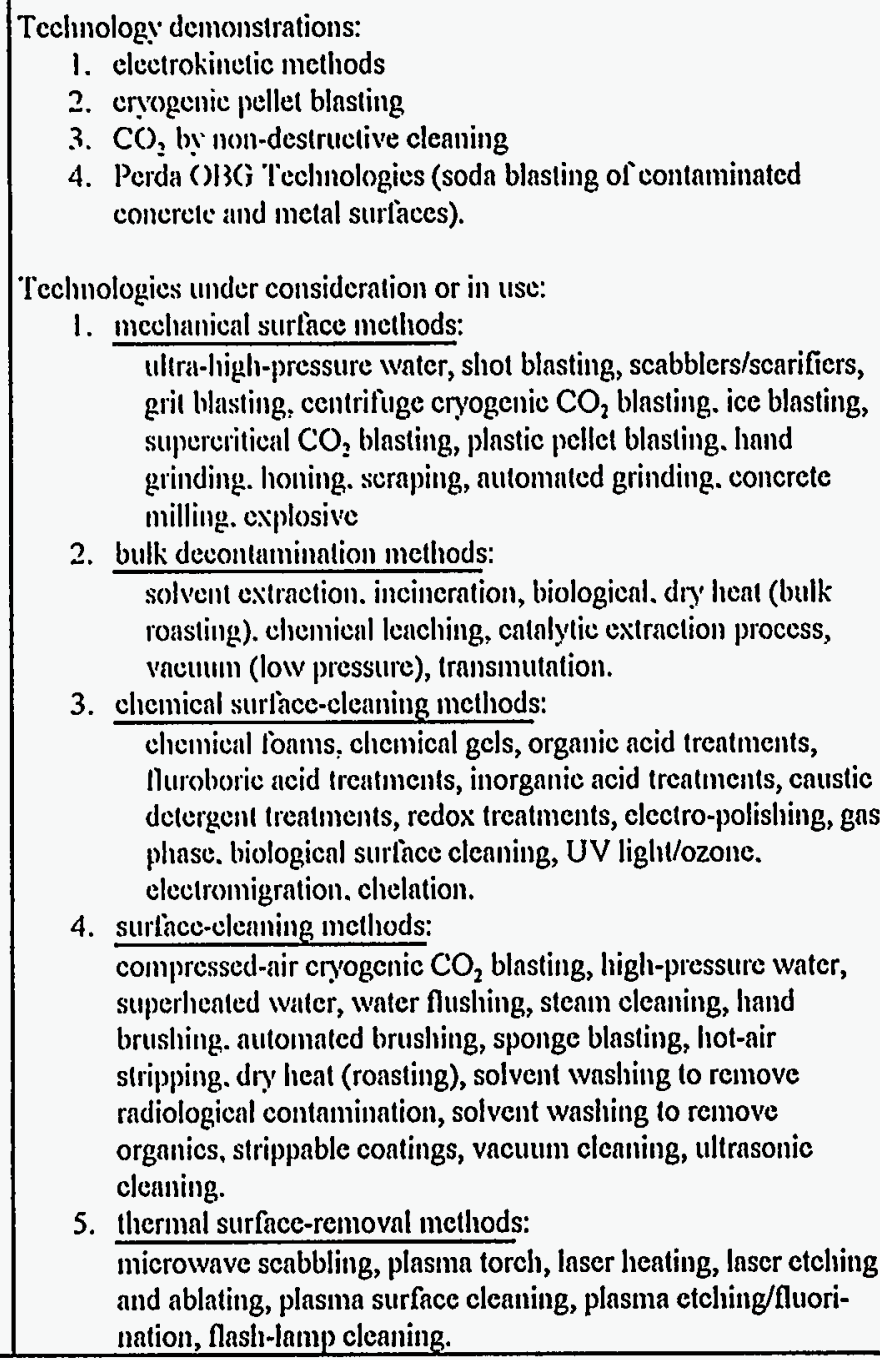 \\
\hline
\end{tabular}


Table A.2. (continued)

\begin{tabular}{|c|c|c|c|}
\hline Facility and Sile & Contaminant & Volume & D\&D Technology and Comments \\
\hline \multicolumn{4}{|l|}{ ORR (cont.) } \\
\hline $\begin{array}{l}\text { Y-12 Plant } \\
\text { Building 92()1-4 hats } \\
\text { been accepted into } \\
\text { the D\&D program. } \\
\text { More than } 20 \text { other } \\
\text { buildings are in the } \\
\text { planning stages tor } \\
\text { D\&D. }\end{array}$ & Hg. U. ${ }^{212}[\mathrm{Th} . \mathrm{Li}, \mathrm{PCBs}$ & $\begin{array}{l}\text { Not known: as much as } 250 \text { tons of } \\
\text { clemental Ilg may' remain in the } \\
\text { building. equipment. and concrete. } \\
\text { Building } 941(1-4 \text { and three other } \\
\text { potentially contuminated buildings } \\
\text { together constitute an estimated } \\
\text { 153.000 } 11^{2} \text { of thoor space. }\end{array}$ & 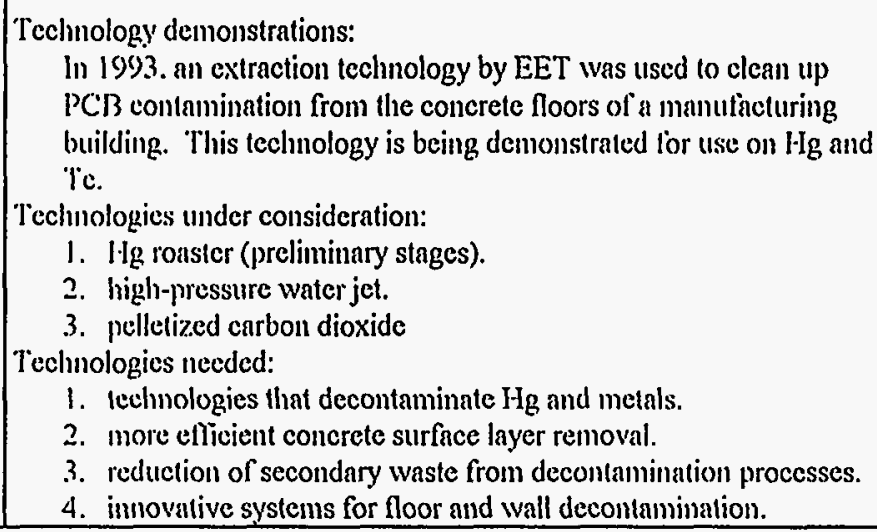 \\
\hline \multicolumn{4}{|c|}{ Paducah Gaseous Diffusion Plant } \\
\hline $\begin{array}{l}\text { 13uildings } C^{-}-340 \\
\text { and } C^{\prime}-410\end{array}$ & $\begin{array}{l}\text { U, some IRU. }{ }^{99} \mathrm{le}, \mathrm{PCB}, \\
\text { chromales. lead paint }\end{array}$ & $\begin{array}{l}\text { Not known: the buildings currently in } \\
\text { the D\&D program constitute an aren of } \\
260,000 \mathrm{ft}^{2}\end{array}$ & $\begin{array}{l}\text { The D\&D program has not yet developed to the point of considering } \\
\text { technologies. It is likely that the logic diagram fiom K-25 (ORR) will } \\
\text { be used for D\&D at Paducah. }\end{array}$ \\
\hline \multicolumn{4}{|c|}{ Portsmouth Gascous Diffusion Plant } \\
\hline Building 705A & $\begin{array}{l}\text { Isotopes of U, possibly some Tc } \\
\text { and TRU. }\end{array}$ & $\begin{array}{l}\text { Not knowil: characterization for D\&D } \\
\text { has not begtun. }\end{array}$ & $\begin{array}{l}\text { Technology demonstrations: } \\
\text { EET applied a chemical extraction process to an epoxy-coated } \\
\text { concrele slab contaminated with beta and gamma radiation. } \\
\text { Contaminant removal was not as effective as hoped because the } \\
\text { radiontuclides were either underneath or bonded to the epoxy. } \\
\text { Teclmologies under consideration: none yet; the D\&D progran is in } \\
\text { the planning stage. Technologies will be considered based on } \\
\text { findings of characterization studies. } \\
\text { Teclinologies needed: not known; areas of contaminated concrete have } \\
\text { not yet been characterized. }\end{array}$ \\
\hline
\end{tabular}


Table A.2. (continued)

\begin{tabular}{|c|c|c|c|}
\hline Facility and Sitc & Contaminant & Volune & D\&D Technology and Comments \\
\hline \begin{tabular}{|} 
Rocky Flats Plant \\
Buildings 371,374, \\
$444,446,707,771$ \\
$774,776,777,779$ \\
881,886, and 901
\end{tabular} & $\begin{array}{l}\mathrm{U}, \mathrm{Pu} \text {, asbestos, chemical (not } \\
\text { specified) }\end{array}$ & $\begin{array}{l}\text { Not known; characterization for D\&D is } \\
\text { just beginning. }\end{array}$ & $\begin{array}{l}\text { Technology demonstrations: } \\
\text { ncedle scabbling; a pilot project was successfully completed using a } \\
\text { dustless decontamination system by Pentek. } \\
\text { Teclmologies under consideration: } \\
\text { scabbling has been used successfully in the past and is planned for } \\
\text { future concrete D\&D. Strippable conting is being considered for } \\
\text { decontanination of glove boxes. } \mathrm{CO}_{2} \text { blaster (dry ice) has been } \\
\text { tried in the past but was not satisfactory. } \\
\text { Technologics needed: not known. }\end{array}$ \\
\hline $\begin{array}{l}\text { Savannal River Site } \\
\text { Five production reac- } \\
\text { tors (four surplused), } \\
\text { surplis fuel fabrica-lion } \\
\text { facility, two fucl } \\
\text { canyons (not yct sur- } \\
\text { plus), devclopment } \\
\text { reactor, } 51 \text { ligh-level } \\
\text { waste tanks, defense } \\
\text { waste processing } \\
\text { facility, numerous } \\
\text { sumport buildings. }\end{array}$ & $\begin{array}{l}\text { Fucl reprocessing canyons have } \\
\text { all isotopes associnted with } \\
\text { dissolved alumintm-clad spent } \\
\text { fucl. }\end{array}$ & $\begin{array}{l}\text { Nol known; reactor buildings have } \\
\text { some surlace concrete contamination, } \\
\text { including spent fuel basius. } \\
\text { Reprocessing canyons liave major } \\
\text { concrete contamination from spills of } \\
\text { radionctive process solutions. }\end{array}$ & $\begin{array}{l}\text { Technology demonstrations: } \\
\text { all conventional technologies have been demonstrated in the past; } \\
\text { many have been used for decontamination. There are no } \\
\text { demonstrations currently in progress (January 1995). } \\
\text { Techmologies under consideration: nol known. } \\
\text { Technologies needed: not known. }\end{array}$ \\
\hline Weldon Spring Sitc & $\mathrm{U}, \mathrm{Th}, \mathrm{Hg}$ & Nol known & $\begin{array}{l}\text { Teclunology demonstrations: not known. } \\
\text { Technologies under consideration: } \\
\text { teclnologies used include high-pressure washers to reduce the } \\
\text { amount of removable radioactive constituents; Nilfisk vacuums to } \\
\text { collect metallic } \mathrm{Hg} \text {, and a commercially available product (not } \\
\text { specified) to stabilize residual } \mathrm{Hg} \text { as a salt. }\end{array}$ \\
\hline
\end{tabular}


Table A.2. (continued)

\begin{tabular}{|c|c|c|c|}
\hline Fracility' and Sitc & Contaminant & Volume & D\&D Teclunology and Comments \\
\hline \multicolumn{4}{|l|}{ West Valley Demonstration } \\
\hline Clicmical Process Cell & ${ }^{1377} \mathrm{Cs} .{ }^{90} \mathrm{Sr} .{ }^{211} \mathrm{Am} . \mathrm{P}_{\mathrm{ul}}$ & $\begin{array}{l}\text { Primary decommissioning waste was } \\
\text { over } 30.000 \mathrm{n}^{3}: \text { an additional } \\
780011^{2} \text { of secondary waste was } \\
\text { generated. }\end{array}$ & 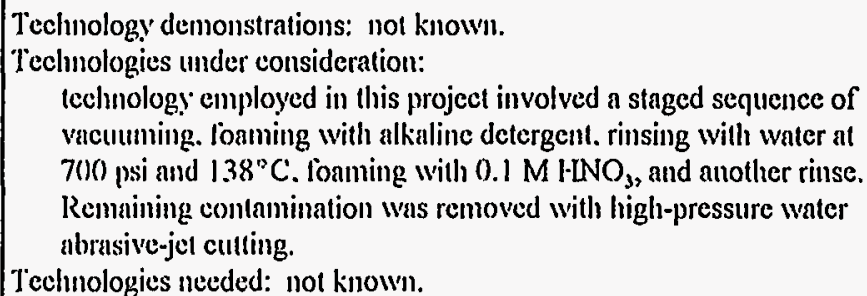 \\
\hline
\end{tabular}

Sources: Personal communication with DOl: representatives (Appendix $\Lambda$ ).

HE:PA: high-efliciency particulate air

redox: reduction-oxidation

I'RU: transuranic (clement)

UV: tiltraviolet

PCBS: polychlorinated biphenyls 


\section{Survey Results}

\section{Facility: Argonne National Laboratory}

Site: CP-5 Reactor Facility (containment structure, rod storage area, spent-fuel canal, and hot cell area).

D\&D Description: prepare the facility for unrestricted use.

Concrete Contamination:

Significance: not known.

Extent:

Containment structure: approximately $1000 \mathrm{ft}^{2}$ to a depth of $1 / 4$ to 1 in.

Rod storage area: $\sim 400 \mathrm{ft}^{2}$ contaminated to a depth of 6 to 8 in. If the storage tubes have been breached, localized areas may be contaminated in a 6-in. radius around the tubes for the affected length of the tube (up to $16 \mathrm{ft}$ deep).

Volume: see above.

Contaminants: ${ }^{60} \mathrm{Co},{ }^{137} \mathrm{Cs}$, and possibly some tritium in the walls and floors of the containment building.

Technology Demonstrations: a demonstration was performed using chemical decontamination of concrete (type not specified). Overall, this technique was rated as unsatisfactory because the floor still contained radioactivity above clean-up criteria upon completion of the demonstration.

Technologies Under Consideration: mechanical demolition and abrading, scabbling, abrasive cleaning, and pneumatic demolition equipment.

Technologies Needed: not known.

Data and Studies Available: Management and Engineering Plan for the D\&D of CP-5.

Disposal Location: HANF. 


\section{(ANL continued)}

Decontamination Schedule:

Start date: not known.

Total treatment time: not known.

Current status: not known.

Decontamination Cost:

Containment structure: $\sim \$ 500,000$

Rod storage area: if tubes are breached, $\$ 500,000$. This could be appreciably higher if the entire monolithic slab must be removed.

Comments: none.

Clean-Up Criteria: DOE Order 5400.5 (U.S. DOE 1990).

References and Contacts:

Mike Coffey (708)252-4315 


\section{Facility: Battelle Columbus Laboratory}

Sites: King Avenue and West Jefferson

D\&D Description: decontamination of concrete.

Concrete Contamination:

Significance: not known.

Extent: not known.

Volume: not known; as of January 1995 , about $200,000 \mathrm{ft}^{2}$ of concrete have been decontaminated. Depth of contamination varies from $1 / 16$ in. to 5 or 6 in.

Contaminants: $\mathrm{U}, \mathrm{Th}$, and some mixed fission products.

Technology Demonstrations: none.

Technologies Under Consideration: none; D\&D personnel were directed to use existing technologies. Method chosen was vacuum blasting and scabbling; jackhammers are used for deep cracks in concrete.

Technologies Needed: none.

Data and Studies Available: not known.

Disposal Location: off site at HANF.

Decontamination Schedule:

Start date: 1993.

Total treatment time: on-going through FY97.

Current status: King Avenue is about 50\% complete (as of January 1995); West Jefferson hasn't started yet.

Decontamination Cost: $\$ 8.50 / \mathrm{ft}^{2}$; cost of $200,000 \mathrm{ft}^{2}$ thus far is $\$ 1.7$ million. 
(BCL continued)

Comments: vacuum blaster removed about $95 \%$ of contamination. Technology has proven effective at this facility, and no problems have been encountered.

Clean-Up Criteria: depends on isotope; cleanup is in accordance with NRC NUREG criteria (document not specified).

References and Contacts:

Ron Carlson (614)424-7074. 


\section{Facility: Brookhaven National Laboratory}

Site: buildings $444,445,446,447,448$, building 811 storage tanks, and Brookhaven graphite research reactor (BGRR) are scheduled for eventual D\&D. Although other areas contain contaminated concrete, these areas are in active use. The original seven operable units at $\mathrm{BNL}$ have been combined into four.

D\&D Description: dismantlement of the buildings; removal, stabilization, and disposal of 68,000-gal underground storage tanks, concrete tank vault, and associated piping at Building 811; decommission BGRR, including graphite pile, biological shield, ancillary items (control drives, air cooling system), and support structures (fuel canal, canal and treatment houses, storage vaults, and radiological waste lines).

Concrete Contamination:

Significance: not known.

Extent:

Buildings 444, 446, 447, 448: not known; contamination in the floor is up to 6 in. deep.

Building 445: unknown; surface and fixed to 6 in. deep.

Building 811 storage tanks: not known; generally surface contamination, possibly soil.

BGRR: estimated that $9000 \mathrm{ft}^{3}$ would be generated if the graphite pile and biological shield were entombed and all other support systems and structures were dismantled. Contamination is generally only surficial; possibly some soil contamination. Three areas of potential contamination have been identified at BGRR:

9A canal: floor and walls of canal are contaminated. Canal capacity is 55,000 gal; dimensions are $64 \mathrm{ft}$ long $\times 6 \mathrm{ft}$ wide $\times 8.5 \mathrm{ft}$ deep, except for a $13 \mathrm{ft} \times 13 \mathrm{ft} \times$ 20 -ft-deep well at the reactor end; the canal chute is $5 \mathrm{ft} \times 13 \mathrm{ft}$. Surface area of contamination and remaining activity are not known.

9B underground ductworks: not known; concrete outer wall of the secondary duct should be clean except where the inner wall of the secondary duct has lost integrity.

9C spill sites: not known. 


\section{(BNL continued)}

Volume:

Buildings: not known.

BGRR: $9,000 \mathrm{ft}^{3}$; if materials could be decontaminated before disposal, both volume and cost of waste could be drastically reduced.

Contaminants:

Buildings $444,446,447,448$ : radioactive (not specified).

Building 445: radioactive (not specified), some alpha, chemical (not specified), and $\mathrm{Hg}$.

Building 811 storage tanks: ${ }^{3} \mathrm{H},{ }^{22} \mathrm{Na},{ }^{60} \mathrm{Co},{ }^{137} \mathrm{Cs},{ }^{211} \mathrm{Bi}$.

BGRR 9A canal: uranium oxide, $\mathrm{Pu},{ }^{60} \mathrm{Co},{ }^{60} \mathrm{Fe},{ }^{137} \mathrm{Cs},{ }^{90} \mathrm{Sr}$.

Technology Demonstrations: not known.

Technologies Under Consideration: not known.

Technologies Needed: any cost-effective methods to manage long-term risks and to decontaminate prior to disposal.

Data and Studies Available: Burns and Roe Co. 1989. Decommissioning Evaluations and Plan for the BGRR, Revision 2. Prepared for Brookhaven National Laboratory, N.Y.

Disposal Location:

Buildings: dismantle and ship to HANF.

BGRR: has not been decided: either entombment or dismantlement.

Decontamination Schedule:

Start date: current projections are that the BGRR will undergo D\&D beginning in 2005 .

Building 811 storage tanks may be dismantled sooner. 


\section{(BNL continued)}

Total treatment time: not known.

Current status: remedial investigation/feasibility study (RU/FS) work is on-going; D\&D has been delayed.

Decontamination Cost:

Buildings 444, 445, 446, 447, 448: unknown.

BGRR: \$3.7 M (FY89 estimated cost) without cost of material disposal. Based on current projections, this estimate is suspected to be low.

Building 811 storage tanks: $\$ 420,000$ (FY94 estimated costs) not including cost of material disposal.

Comments: none.

Clean-Up Criteria: have not been established.

References and Contacts:

References:

BNL. 1948. Brookhaven Nuclear Reactor. Brookhaven National Laboratory, N.Y.

BNL. 1948. Supplement to Report on the Brookhaven Nuclear Reactor. Brookhaven National Laboratory, N.Y.

BNL. 1960. Graphite Research Reactor; Facilities and Services Guide. Revised. Brookhaven National Laboratory, N.Y.

BNL. 1975. 1975 Site Waste Management Plans. Brookhaven National Laboratory, N.Y.

Boutelle, R. 1957. Memo to L. Gemmell, Progress Report - January, February 8, 1957. Brookhaven National Laboratory, N.Y.

Boutelle, R. 1958. Memo to L. Gemmell, Progress Report - January, February 11, 1958. Brookhaven National Laboratory, N.Y.

Brookhaven National Laboratory Site Baseline Report, 1992. 


\section{(BNL continued)}

Burns and Roe Co. 1989. Decommissioning Evaluations and Plan for the BGRR, Revision 2. Prepared for Brookhaven National Laboratory, N.Y.

ERDA. 1977. Final Environmental Impact Statement, Brookhaven National Laboratory. ERDA-1540. U.S. Energy Research and Development Administration.

Humm, A. F., and S. R. Protter. 1963. Reconditioning the BGRR Fuel Storage Canal. NUCLE-ONICS.

ITC. 1989. Underground Storage Tanks Sampling \& Analysis Plan for BNL.

ITC. 1989. Soil Sampling \& Analysis Plan for BNL.

Keene, B. 1954. Memo to L. Gemmell, Progress Report - January 28, 1954. Brookhaven National Laboratory, N.Y.

Phillips, J. 1984. Memo to G. Kinne, BGRR Canal Facility D\&D, May 14, 1984. Brookhaven National Laboratory, N.Y.

Pile Group. 1956. Memo to L. Gemmell, Progress Report - September 1956, October 9, 1956. Brookhaven National Laboratory, N.Y.

Porcelli, D., and J. Naidu. 1990. BNL-Environmental Data Review. Brookhaven National Laboratory, N.Y.

Powell, R. 1990. Memo to R. Howe, Comments on SBR - Draft, September 2, 1990. Brookhaven National Laboratory, N.Y.

Reyer, R. J. 1986. Memo to G. C. Kline, BGRR Canal Water Treatment Facility Decontamination and Decommission Project, November 12, 1986. Brookhaven National Laboratory, N.Y.

U.S. DOE. 1988. Emvironmental Survey Preliminary Report. Brookhaven National Laboratory, N.Y.

Contacts:

Bob Litzke (516)282-5689 or (516)282-2818

Paul Kald (516)282-7644 


\section{Facility: Energy Technology Engineering Center}

Site: buildings T012, T020, T021, T022, T024, T059; Radioactive Materials Disposal Facility (RMDF).

D\&D Description: sites contain low-level activated concrete and low-level fission products.

Concrete Contamination:

Significance: most significant remaining contamination at ETEC is surface $(<1$ in. deep). Buildings T024 and T059 have very low levels of activated concrete. Based on the high cost of removing essentially background levels of radioactivity, the current plan for Building T0249, a former reactor test cell, is to allow the radioactivity to decay in place over the next 75 years. Building T059, also a former reactor test facility, has undergone major D\&D over the last five years; based on a pathway analysis and cost evaluation, it was again concluded that a below-grade vault with very low levels of residual radioactivity should be filled with concrete to exclude future occupancy and left in place.

Extent:

T020: $90 \%$ of contaminated concrete has been removed using conventional techniques.

T012: $\sim 500 \mathrm{ft}^{2}$ floor area and minor contamination on wall surfaces.

T021: $\sim 2500 \mathrm{ft}^{2}$ concrete floor.

T022: seven underground, dry, irradiated fuel storage vaults approximately $25 \mathrm{ft} \times$

$12 \mathrm{ft} \times 20 \mathrm{ft}$ deep. One contains an 8000-gal low-level liquid waste hold-up tank; several contain fuel storage racks that must be removed and decontaminated. Preliminary surveys of two of the seven vaults show no contamination. It is anticipated that localized contamination will be found on the floors due to contaminated liquids and minor spills in the vaults. Scabbling to $1 / 8$ to $1 / 4$ in. is expected to remove these contaminants.

T024: not known. 


\section{(ETEC continued)}

T059: not known.

RMDF: not known.

Volume: not known; contamination is generally $<1$ in. deep.

Contaminants:

T024 and T059: ${ }^{60} \mathrm{Co},{ }^{55} \mathrm{Fe},{ }^{152} \mathrm{Eu}$, and ${ }^{154} \mathrm{Eu}$ at nonhazardous levels.

T012: low levels of fixed alpha (enriched uranium); background levels.

T020: ${ }^{137} \mathrm{Cs},{ }^{60} \mathrm{Co},{ }^{90} \mathrm{Sr} / \mathrm{Y}$, some uranium, and some TRU; $<5 \mathrm{mR} / \mathrm{h}$.

T021: mixed fission products; $<5 \mathrm{mR} / \mathrm{h}$.

T022: mixed fission products; $<5 \mathrm{mR} / \mathrm{h}$.

Technology Demonstrations: in FY95 at building T022, a project funded by EM-50, "Remote Mechanical Methods for Decontaminating Concrete Walls," will demonstrate a remote delivery system capable of performing radiological surveys and concrete decontamination on vertical surfaces. ETEC-developed remotely operated equipment was used to decontaminate Building T059 from 1993 through 1995.

Technologies Under Consideration: all concrete D\&D is currently being performed using conventional technologies, including mechanical scabbling for surface decontamination and removal of grossly contaminated concrete by backhoe-mounted hydraulic hammer or manually operated jackhammer. Contamination at depth is removed by core drilling.

Technologies Needed: not known.

Data and Studies Available: not known.

Disposal Location: radioactive waste from Building T020 is disposed of at NTS; all other radioactive waste is disposed of at HANF. 


\section{(ETEC continued)}

Decontamination Schedule:

Start date: not known.

Total treatment time: not known.

Current status:

T020: seven-year project is scheduled to be completed in FY97.

T021 and T022: planning is scheduled to begin in the second half of FY95 and D\&D scheduled to be completed in FY97.

T012: planning is complete; D\&D to be done in FY95.

Decontamination Cost:

T020: estimated at $\$ 20 \mathrm{M}$.

T021 and T022: estimated at $\$ 5 \mathrm{M}$.

T012: estimated at $\$ 200 \mathrm{M}$.

Comments: a conventional tractor-mounted backhoe and commercial remote equipment used by Rockwell International for in-service inspection of nuclear power reactors have been successfully adapted to major D\&D projects at ETEC. Standard D\&D tools, including hydraulic hammer, hydraulic shear, bucket, and plasma torch, were also adapted for D\&D use with the above equipment. In-house-designed and -fabricated remotepositioning systems for plasma arc cutting of cell steel liners were also successfully used in the T059 project. All remote systems were checked out and techniques optimized in cold mock-ups prior to installation in irradiated facilities.

Clean-Up Criteria: DOE 5400.5 (U.S. DOE 1990) and California regulations for free release. A pathway analysis (using RESRAD computer code) is applied to contamination left in place (e.g., a below-grade concrete vault containing residual radioactivity was backfilled to provide shielding). Waste classified as nondetectable and hauled off site undergoes a statistical analysis of the sampling to provide a $95 \%$ confidence interval that no hot spots are in the waste. 
(ETEC, continued)

References and Contacts:

References:

Harris, J.M. 1980. Diamond Ordinance Radiation Facility Decommissioning Program (final report). Energy Systems Group, Rockwell International.

Liddle, R., T. Moss, and P. Horton. 1993. Rockwell experience on D\&D of the Rockwell International Hot Laboratory. Paper presented at ER '93, Department of Energy Environmental Remediation Conference, October 24-28, 1993.

Meyer, R.D., P.H. Waite, and G. Subbarman. 1993. Remote plasma arc cutting and removal of a test reactor vessel. Paper presented at ER '93, Department of Energy Environmental Remediation Conference, October 24-28, 1993.

Sturtevant, W.C., R.D. Meyer, P.H. Horton, and G. Subbarman. 1993. Paper presented at Waste Management '93, February 28-March 3, 1993.

Contacts:

Phil Horton (818)586-5384

Rod Meyers (818)586-5400

Phil Rutherford (818)586-6140 (manager of Health Physics)

Jim Barns (818)586-5766 (radiation safety officer) 


\section{Facility: Fernald Environmental Management Project}

Site: Operable unit (OU) 3, K-65 silos (silos 1 and 2).

D\&D Description: of the 5 OUs at FEMP, only OU 3 has concrete contamination.

Numerous buildings and structures will undergo D\&D; most of the buildings have concrete floors and structural steel skeletons covered with transite. The most difficult D\&D efforts may involve smaller, more unusual activities, such as the D\&D of the K-65 silos.

Concrete Contamination:

Significance: without decontamination to reduce the volume requiring disposal, concrete would be one of the major contributors to the total volume of waste. The largest single $\mathrm{D} \& \mathrm{D}$ problem is contaminated metal.

Extent: not known.

Volume: $3.3 \times 10^{6} \mathrm{ft}^{3}$.

Contaminants: U, Th.

Technology Demonstrations: FEMP has been selected for a site demonstration of electrohydraulic scabbling (currently scheduled for September 1995); facility is also under consideration for hosting a demonstration of concrete surface decontamination using laser ablation.

Technologies Under Consideration: a variety of technologies will be used to decontaminate concrete. The approach presently in use is to provide performance specifications to the subcontractor and allow the subcontractor to choose a technology. Documents pertaining to treatability and feasibility studies of the site are used to evaluate the selected technology to ensure that it is safe and cost effective.

Technologies Needed: not known.

Data and Studies Available: see References and Contacts.

Disposal Location: concrete waste acceptable for burial in a sanitary landfill will be buried on site. Wastes not suitable for a sanitary landfill will be disposed of in an on-site disposal cell if the waste meets the cell's WAC. Wastes that do not meet the FEMP WAC will be hauled to NTS or Envirocare, South Clive, Utah, depending on the waste type and continued access to the site. 


\section{A-32}

\section{(FEMP continued)}

Decontamination Schedule: this is currently under development.

Decontamination Cost: not yet established.

Comments: there have been numerous delays in obtaining valid radiometric analyses from off-site laboratories. Problems cited by the laboratories include:

- the fact that concrete is an unusual medium for this type of analysis (i.e., neither water nor soil);

- matrix interferences that had not been encountered before;

- problems with contract clarity;

- information requested by the facility was not what the laboratory normally provided.

Clean-Up Criteria: Interim ROD states that all buildings in the D\&D program will be torn down and removed; consequently, all contaminated concrete will be cleaned up. As of January 1995, it had not been decided if the surface contamination will be removed, thus reducing the contaminated waste disposal volume, or if the entire volume, contaminated exterior and uncontaminated interior, will be disposed of in bulk. RI/FS is still in progress.

References and Contacts:

References:

Operable Unit 3 Work Plan Addendum, Remedial Investigation and Feasibility Study, Rev. 3 (final).

Operable Unit 3 Treatability Study Work Plan (final).

Operable Unit 3 Remedial Design:Remedial Action Work Plan, Rev. 0. This also includes the sampling and analysis plan, health and safety plan, operations and maintenance plan, and the construction quality assurance plan.

Operable Unit 3 Building 4A Implementation Plan (draft).

Operable Unit 3 Record of Decision for the Interim Remedial Action. June 1994. 


\section{(FEMP continued)}

Contacts:

Dick Martineit (513)648-6386, general information for all areas.

Joe Boudreaux (513)738-9455, questions specific to the D\&D of structures included in the scope of OU 3.

Lorie Miller (513)738-9471, questions concerning the referenced studies or plans.

Sue Madaris (513)870-8309, questions about the characterization of media involved in OU 3 D\&D activities.

Tom Vunak (513)738-6121, questions about the cost and schedule for the OU 3 D\&D program. 


\section{Facility: Formerly Utilized Sites Remedial Action Project}

Site: there are 46 FUSRAP sites throughout 14 states.

D\&D Description: 17 facilities have completed D\&D. Others are in the planning or characterization stages.

Concrete Contamination:

Significance: not known.

Extent: not known.

Volume: not known; not all sites have been characterized.

Contaminants: generally uranium; some thorium and metals.

Technology Demonstrations: not known.

Technologies Under Consideration: the preferred method at Aliquippa Forge, Pennsylvania, and Colonie, New York, is to use a strong vacuum for eliminating removable contamination and then to crush the concrete to soil-sized particles. The advantage to this method is that the disposal facility charges $\$ 8 / \mathrm{ft}^{3}$ for soil disposal versus $\$ 18 / \mathrm{ft}^{3}$ to dispose of rubble and debris. An additional advantage is that often the homogenized concrete "soil" is below clean-up criteria and can be spread around or used as fill.

Technologies Needed: not known.

Data and Studies Available: not known.

Disposal Location: not known.

Decontamination Schedule: D\&D scheduling depends on funding each year. Seventeen of the 46 sites have completed D\&D. The FUSRAP D\&D program is scheduled for completion in 2016. Seven sites are scheduled for D\&D in FY95.

Start date: not known. Schedule for the Colonie site is to start demolition in April 1995, begin concrete crushing operations in July, and finish D\&D in August. The current timetable calls for crushing $4000 \mathrm{yd}^{3}$ of concrete in two weeks.

Total treatment time: not known.

Current status: not known. 


\section{(FUSRAP continued)}

Decontamination Cost: cost varies considerably depending on the method chosen and whether the decontaminated material can be left on site or must be hauled to a disposal facility. At Aliquippa Forge, for example, $600 \mathrm{yd}^{3}$ of concrete were cleaned up. The estimated cost for disposing of rubble was $\$ 291,000\left(600 \mathrm{yd}^{3} \times \$ 486 / \mathrm{yd}^{3}\right)$. By crushing the concrete to soil-sized particles, the cost was reduced to $\$ 129,600\left(600 \mathrm{yd}^{3} \times \$ 216 / \mathrm{yd}^{3}\right)$. The savings paid for the rock crusher. A comparison of costs found that it was much cheaper to crush the concrete and dispose of it or use it for fill than to decontaminate the surface. This was especially true for walls. Vacuuming costs about $\$ 4.70 / \mathrm{ft}^{2}$; surface blasting with the intention of meeting release criteria costs about $\$ 66 / \mathrm{ft}^{2}$. Scabbling and other surface decontamination methods were too labor-intensive compared to crushing.

.Comments: none.

Clean-Up Criteria: specific to each site. Typically, a RESRAD model is used to derive a preliminary dose rate; then ALARA considerations are applied. The RESRAD value is usually much higher than the final ALARA number.

References and Contacts:

Melissa Noe (615)241-3315

Ron Kirk (615)576-7477

Jim Kopotic (615)576-9441

Dave Adler (615)576-9634 


\section{Facility: Grand Junction Projects Office}

Site: 1 building.

D\&D Description: remove surface contamination from concrete floor.

Concrete Contamination:

Significance: unknown but presumably not significant.

Extent: $-300 \mathrm{ft}^{2}$.

Volume: less than one 5-gal bucket.

Contaminants: uranium mill tailings; low-level ${ }^{226} \mathrm{Ra}$ and decay products.

Technology Demonstrations: not known.

Technologies Under Consideration: none; needle scabbling was used for remediation.

Technologies Needed: none.

Data and Studies Available: not known.

Disposal Location: off site at Cheny Reservoir.

Decontamination Schedule: not known.

Start date: not known.

Total treatment time: not known.

Current status: concrete decontamination has been completed.

Decontamination Cost: not known.

Comments: volume was so small that the cost of overhead was much higher than the cost of remediating the concrete slab.

Clean-Up Criteria: DOE 5400.5 (U.S. DOE 1990). 
A-37

(GJPO continued)

References and Contacts:

Steve Corle (303)248-6497. 


\section{Facility: Hanford Reservation}

Site: 100 Area, 200 Area, 300 Area

D\&D Description: a total of 147100 Area surplus facilities are currently in the D\&D scope of work, with the transition of more expected in the next few years. Eight of the nine production reactor buildings and 138 reactor support buildings and related facilities must be decontaminated and demolished to clean up the 100 Area. The multi-story buildings are constructed of steel and concrete; they contain multiple rooms with tons of mechanical and electrical equipment that must be removed and recycled or disposed of before the buildings can be decontaminated and demolished.

The 200 Area contains office buildings, canyon facilities, laboratories, shops, other ancillary facilities and WM units, including underground radioactive waste storage tanks on the 200 Area Plateau. The large concrete and steel structures are beginning the transition status from surplus to D\&D.

Buildings in the 300 Area are generally smaller than the 100 Area and 200 Area facilities and are mostly constructed from concrete and steel or concrete block.

Concrete Contamination:

Significance: not known.

Extent:

100 Area: concrete contamination occurs within the fuel reactor storage basins and, to a minor extent, within the retention basins which held "once-through" cooling water until it had thermally cooled sufficiently to be released into the Columbia River.

200 Area: contamination occurs on the tops of concrete tank domes, within concrete valve boxes, in piping tunnels, and within hot cells and process equipment bays. Spills may have contaminated some concrete surfaces near transfer areas. Pump and valve pits may contain both radiologic and non-radiologic contamination.

300 Area: radiologic (especially uranium) and non-radiologic contamination has resulted from spills on laboratory floors, in sumps, within piping tunnels, and onto other concrete surfaces. 


\section{(HANF continued)}

Volume: not known; volumes vary according to the method of decontamination used. If surface contamination cannot be removed, and "decontamination" requires demolition and disposal of the entire structure, the volumes are large. If the contaminated concrete surfaces can be removed, volumes are reduced to a few millimeters deep times the areas of the structures.

Volume estimates: 100 Area reactor cores: $37,000 \mathrm{ft}^{3}$.

200 Area chemical process facilities: $1.7 \times 10^{6} \mathrm{ft}^{3}$.

300 Area: no estimate.

\section{Contaminants:}

100 Area: contamination in the fuel storage basins consists of fission products from the fuel elements. Retention basins contain activation products from the reactor core. As a result of pipe leaks, concrete pipe tunnels extending from the reactor to the retention basins may also be contaminated with activation products. Non-radiologic contaminants in the 100 Area will most likely be from spills of petro-chemicals and hazardous materials (nitrates and chromium) during transfer from shipping containers (carboys, rail cars, tanks) to pipes or other containers.

200 Area: plutonium and other alpha emitters and hazardous contaminants such as nitrates and metals.

300 Area: both radiologic and non-radiologic contaminants.

In general, contaminants that may be found to some degree in concrete at the sites include $\mathrm{Sr}, \mathrm{Cs}, \mathrm{Pu}, \mathrm{U}, \mathrm{Tc},{ }^{60} \mathrm{Co},{ }^{14} \mathrm{C}, \mathrm{Am}, \mathrm{Cu}, \mathrm{Ag}, \mathrm{I}, \mathrm{Cr}$, nitrates, cyanides, and chloroform.

Technology Demonstrations: not known.

Technologies Under Consideration: technologies assessed by Pacific Northwest Laboratory (PNL) include dry-ice blasting, arc saw, burial ground stabilization, electropolishing/vibratory finishing, fixatives, water cannon, concrete spalling, and high-pressure hot water jet. Laser ablation has been used by PNL on the "bath tub ring," a pool of cesium-contaminated water from which cesium atoms have absorbed into concrete walls at the water surface. Chemical methods of concrete decontamination have been tried at HANF with mixed (and expensive, from a disposal standpoint) results. The shot-peen, needle guns, and sandblasting are standard physical techniques used at HANF for decontaminating concrete surfaces. These methods can remove contamination to the desired depth and can be used either wet or dry with a HEPA filtration system attached to a vacuum at the shotpeen actuator.

Technologies Needed: none; technical approach has been developed. 


\section{(HANF continued)}

Data and Studies Available: not specified; available references include characterization reports that can be found in public records pertaining to $D \& D$ activities.

Disposal Location: low-level and mixed low-level contaminated materials are disposed of on site in the WM area on the 200 Area plateau.

Hazardous materials have been shipped off site to Arlington, Oregon, or disposed of on site on land leased to the state of Washington, or in DOE waste disposal facilities.

Current plans are to build a waste disposal facility for managing wastes from the 100 Area remediation. The waste disposal facility, which will accept hazardous, low-level, and mixed low-level wastes, will become operational in FY97.

Decontamination Schedule: concrete decontamination is currently underway at the HANF as surplus buildings are being prepared for demolition.

Total treatment time: not known. Shot-peen decontamination may take 1 to 2 passes at about one second per pass with a total decontaminated area of 64 in. ${ }^{2}$ Using laser ablation to decontaminate concrete in air, the estimated contaminant removal rate is about $65 \mathrm{in}^{2} / \mathrm{h}$ to a depth of $1 / 4$ in.; rates for underwater concrete would be considerably reduced.

Current status: as of January 1995, a total of 147100 Area surplus facilities are in the D\&D work scope, with the transition of more expected in the next few years. Before demolition of the reactor facilities, an engineering assessment will be performed to characterize the extent of contamination within the structures. This assessment will be used to define the measures necessary to protect the health and safety of the workers, prevent further spread of contamination, and identify material that can be recycled or reused.

Decontamination Cost: not known. Because of the extremely large surface area of contaminated concrete and slow rate of decontamination, much of the cost will be based on the labor rate required for this labor-intensive process.

Comments: none.

Clean-Up Criteria: DOE 5400.5, Chapter 4, pp. 3 -7 (U.S. DOE 1990).

References and Contacts:

Rich Hudson (509)372-1270. 
Facility: Idaho National Engineering Laboratory

\section{Overview of D\&D}

The INEL D\&D Program was established in late 1977 and has remained active. Forty-five surplus contaminated facilities were originally identified, and 24 have been decommissioned to date. Westinghouse Idaho Nuclear Company (WINCO) is responsible for D\&D of surplus facilities at the ICPP, and EG\&G Idaho is responsible for D\&D of surplus facilities at Test Area North (TAN), Test Reactor Area (TRA), Central Facilities Area (CFA), Power Burst Facility (PBF), Auxiliary Reactor Areas (ARAs), and the reactor experimental areas located near the Radioactive Waste Management Complex (RWMC). Surplus facilities at ANLW and the Naval Reactors Facility (NRF) are managed by Westinghouse Electric Corporation and are under a separate D\&D program (Buckland et al. 1993). Facilities associated with ICPP will require $D \& D$ within the next decade; however, these facilities have not yet been characterized.

Fifty-two reactors exist at INEL; eight are still operational. The phased-out reactors form the basis of the INEL D\&D program. In general, contaminants of concern are radionuclides and heavy metals $(\mathrm{Cr}, \mathrm{Hg}, \mathrm{Pb})$.

Scabbling has been used for most of the concrete decontamination at INEL. However, problems with contaminant penetration into deep cracks has occurred. In the past, scabbling has been the selected option due to cost. Innovative decontamination methods often prove to be more expensive than traditional methods, primarily because of available on-site disposal. INEL has prepared an in-depth D\&D Technology Logic Diagram to suggest solutions and provide technical alternatives to D\&D problems (INEL 1994). Table A.3 is from the INEL logic diagram and lists the methods accepted, the methods requiring demonstration or R\&D, and the estimated volume of waste the method could treat.

One major need that surfaced from the INEL evaluation is that of decontaminating concrete surfaces to avoid large volumes of rubble that will require disposal. This is especially true if the rubble is a mixed waste.

The following descriptions are only a sampling of INEL facilities that have seen or will see significant concrete decontamination. Detailed histories, physical descriptions, maps, etc. are provided in the INEL long range plan (Buckland et al. 1993). 


\section{A-42}

Table A.3. INEL decontamination technology summary

\begin{tabular}{|c|c|c|}
\hline Technology Category & Status & Volume, $\mathrm{ft}^{3}$ \\
\hline Solvent extraction & DT\&E needed & 571,500 \\
\hline Incineration & Accepted & Unknown \\
\hline Biological & R\&D needed & 318,700 \\
\hline Dry heat & R\&D needed & 321,100 \\
\hline Chemical leaching & DT\&E needed & 477,900 \\
\hline Catalytic extraction process & R\&D needed & 158,700 \\
\hline Vacuum & Accepted & 4,300 \\
\hline Chemical foams & DT\&E needed & 473,200 \\
\hline Chemical gels & DT\&E needed & 473,200 \\
\hline Organic acid treatment & DT\&E needed & 156,400 \\
\hline Fluoroboric acid treatment & DT\&E needed & 473,200 \\
\hline Inorganic acid treatments & Accepted & 156,400 \\
\hline Caustic treatment & Accepted & 156,400 \\
\hline Redox treatments & DT\&E needed & 156,400 \\
\hline Electropolishing & Accepted & 156,400 \\
\hline Biological surface cleaning & R\&D needed ${ }^{\circ}$ & 474,300 \\
\hline Laser-activated chemistry & R\&D needed & 156,400 \\
\hline Ultraviolet light (UV)/ozone & DT\&E needed & 156,800 \\
\hline Electromigration & R\&D needed & 316,800 \\
\hline Organic solvent treatment & Accepted & 1,100 \\
\hline Phosphoric acid treatment & Accepted & 156,400 \\
\hline Oxalic acid treatment & Accepted & 156,400 \\
\hline Hydrochloric acid treatment & Accepted & 156,400 \\
\hline Sulfamic acid treatment & DT\&E needed & 156,400 \\
\hline Detergents and surfactants & Accepted & 473,200 \\
\hline Bleaching & Accepted & 1,100 \\
\hline Acid etching & Accepted & 474,300 \\
\hline Lead-based paint removal & Accepted & 1,100 \\
\hline
\end{tabular}


Table A.3. (continued)

\begin{tabular}{||l|l|c||}
\hline \multicolumn{1}{|c|}{ Technology Category } & Status & Volume, $\mathrm{ft}^{3}$ \\
\hline \hline Photochemical degradation & DT\&E needed & 1,100 \\
\hline Smelt purification & DT\&E needed & 156,400 \\
\hline Ultra-high-pressure water & Accepted & 474,300 \\
\hline Shot blasting & Accepted & 474,300 \\
\hline Scabblers/scarifiers & Accepted & 316,800 \\
\hline Grit blasting & Accepted & 473,200 \\
\hline Centrifugal cryogenic $\mathrm{CO}_{2}$ blasting & DT\&E needed & 473,200 \\
\hline Ice blasting & Accepted & 473,200 \\
\hline Supercritical CO $\mathrm{C}_{2}$ & DT\&E needed & 473,200 \\
\hline Plastic pellet blasting & Accepted & 473,200 \\
\hline Hand grinding, honing, scraping & Accepted & 473,200 \\
\hline Automated grinding & DT\&E needed & 473,200 \\
\hline Metal milling & Accepted & 156,400 \\
\hline Concrete milling & R\&D needed & 316,800 \\
\hline Explosive & DT\&E needed & 316,800 \\
\hline Drill and spall & Accepted & 316,800 \\
\hline High-pressure jet spalling & Accepted & 316,800 \\
\hline Compressed-air cryogenic $\mathrm{CO}_{2}$ blasting & Accepted & 473,200 \\
\hline High-pressure water & Accepted & 473,200 \\
\hline Superheated water & Accepted & 473,200 \\
\hline Hot water & Accepted & 473,200 \\
\hline Steam cleaning & Accepted & 473,200 \\
\hline Hand brushing & Accepted & 474,500 \\
\hline Automated brushing & DT\&E needed & 474,500 \\
\hline Sponge blasting & Accepted & 473,200 \\
\hline Hot air stripping & DT\&E needed & 1,100 \\
\hline Dry heat roasting & DT\&E needed & 1,100 \\
\hline Solvent washing & R\&D needed & 473,200 \\
\hline Solvent washing to remove organics & R\&D needed & 1,100 \\
\hline & & \\
\hline
\end{tabular}


A-44

Table A.3. (continued)

\begin{tabular}{|l|l|c||}
\hline \multicolumn{1}{|c|}{ Technology Category } & Status & Volume, $\mathrm{ft}^{3}$ \\
\hline \hline Strippable coatings & Accepted & 473,200 \\
\hline Vacuuming (low pressure) & Accepted & 473,200 \\
\hline Ultrasonic cleaning & Accepted & 156,400 \\
\hline Microbial degradation & R\&D needed & 474,500 \\
\hline Fixative/stabilizer coatings & DT\&E needed & 474,500 \\
\hline K-20 sealant & DT\&E needed & 474,500 \\
\hline Microwave scabbling & DT\&E needed & 316,800 \\
\hline Plasma torch & R\&D needed & 473,200 \\
\hline Laser heating & DT\&E needed & 156,400 \\
\hline Laser etching and ablation & DT\&E needed & 156,400 \\
\hline Plasma surface cleaning & DT\&E needed & 156,400 \\
\hline Plasma etching/fluorination & DT\&E needed & 156,400 \\
\hline Flashlamp cleaning & DT\&E needed & 156,400 \\
\hline Alkaline salts & DT\&E needed & 474,500 \\
\hline Complexing agents & DT\&E needed & 473,200 \\
\hline Flaming & Accepted & 1,100 \\
\hline Turbulator & Accepted & 156,400 \\
\hline Vibrating finishing & Accepted & 156,400 \\
\hline Wet abrasive cleaning & Accepted & 156,400 \\
\hline
\end{tabular}

Source: INEL 1994. 


\section{(INEL continued)}

Site: ARA I

D\&D Description: ARA I was built in support of military nuclear reactor programs in the late 1950s. It is comprised of two buildings (ARA-626 and ARA-247) that contain offices, laboratory space, and hot cell facilities. The D\&D-recommended methodology is total dismantlement and unrestricted release of the site. All reactors were removed or dismantled when decommissioned. Presently, surveillance and maintenance activities are on-going.

Concrete Contamination:

Significance: concrete contamination is associated with the hot cells that are constructed of high-density concrete, with walls up to $0.94 \mathrm{~m}$ thick, and are designed to handle high-level radioactivity.

Extent: provided in characterization study.

Volume: $202 \mathrm{~m}^{3}$ (waste volume).

Rubble: $14 \mathrm{~m}^{3}$ (waste volume).

Contaminants: ${ }^{60} \mathrm{Co},{ }^{137} \mathrm{Cs}$, and others (not specified).

Technology Demonstrations: not known.

Technologies Under Consideration: see Table A.3.

Technologies Needed: see Table A.3:

Data and Studies Available: characterization study (see References).

Disposal Location: on site.

Decontamination Schedule:

Start date: D\&D activities were initiated prior to FY92 and funded through FY97.

Total treatment time: 4 years.

Current status: surveillance and maintenance are on-going. 


\section{(INEL ARA I continued)}

Decontamination Cost: total estimated cost is $\$ 6,342,000$.

Comments: this facility is on the DOE Surplus Facilities List (DOE Order 5820.5A) (U.S. DOE 1988).

Clean-Up Criteria: DOE Order 5400.5 (U.S. DOE 1990). D\&D release criteria specific to INEL application were developed in 1986 (EG\&G 1986). Additional considerations exist for projects subject to CERCLA.

References and Contacts:

References:

Buckland, R.J., D. J. Kenoyer, and D. H. Preussner. 1993. INEL D\&D Long-Range Plan. Idaho National Engineering Laboratory, EG\&G, Idaho Falls, Idaho.

EG\&G. 1986. Development of Criteria for Release of INEL Sites Following D\&D. EGG-2400. EG\&G, Idaho Falls, Idaho.

INEL. 1994. Idaho National Engineering Laboratory Decontamination and Decommissioning Technology Logic Diagram. EEG-WTD-11104. EG\&G, Idaho Falls, Idaho.

Larsen, D.J., and T.N. Thiel. 1993. Characterization and Decision Analysis for Auxiliary Reactor Area I (revision O). EGG-WM-10757. EG\&G, Idaho Falls, Idaho.

U.S. DOE. 1988. Radioactive Waste Management. DOE Order 5820.2A. U.S. Department of Energy.

Contacts:

R. J. (Russ) Buckland, D\&D. (208)526-9813.

Don Harrison, Database Management. (208)526-7514.

Kip Archibald, Technology Development. 


\section{(INEL continued)}

Site: ARA II.

D\&D Description: the ARA II facilities have been funded for D\&D from FY92 through FY97. A military reactor testing program was conducted at ARA II from 1958 to 1960. The SL-1 reactor building was buried $1600 \mathrm{ft}$ northeast of ARA II. Clean-up operations were completed in 1961; afterwards, buildings were used as offices and shops until 1986. ARA II has been abandoned since 1986. The recommended D\&D method is to remove all eight buildings, nine structures, and underground utilities.

Concrete Contamination:

Significance: concrete contamination is associated with the reinforced concrete of the building's floors. All structures contain varying amounts of low-level radiological contamination.

Extent: provided in characterization study (Bradford and Clark 1984).

Volume: $593 \mathrm{~m}^{3}$ (waste volume).

Rubble: $209 \mathrm{~m}^{3}$ (waste volume).

Contaminants: ${ }^{137} \mathrm{Cs},{ }^{60} \mathrm{Co},{ }^{154} \mathrm{Eu},{ }^{235} \mathrm{U},{ }^{90} \mathrm{Sr}, \mathrm{U}, \mathrm{Pu}$.

Technology Demonstrations: not known.

Technologies Under Consideration: not known.

Technologies Needed: refer to Table A.3.

Data and Studies Available: characterization study (Bradford and Clark 1984).

Disposal Location: on site.

Decontamination Schedule:

Start date: FY92 through FY96.

Total treatment time: 5 years. 


\section{(INEL ARA II continued)}

Current status: surveillance and maintenance; most of concrete decontamination is finished or in progress.

Decontamination Cost: total estimated cost is $\$ 1,077,000$.

Comments: this site was characterized for radiological contamination in 1984 and again in 1991 for hazardous substances.

Clean-Up Criteria: DOE Order 5400.5 (U.S. DOE 1990). D\&D release criteria specific to INEL application were developed in 1986 (EG\&G 1986). Additional considerations exist for projects subject to CERCLA.

References and Contacts:

References:

Buckland, R.J., D. J. Kenoyer, and D. H. Preussner. 1993. INEL D\&D Long-Range Plan. Idaho National Engineering Laboratory, EG\&G, Idaho Falls, Idaho.

Bradford, J.D., and J.H. Clark. 1984. Characterization and Decision Analysis for the ARA-II, PT-WM-84-101.

EG\&G. 1986. Development of Criteria for Release of INEL Sites Following D\&D. EGG-2400. EG\&G, Idaho Falls, Idaho.

INEL. 1994. Idaho National Kingineering Laboratory Decontamination and Decommissioning Technology Logic Diagram. EGG-WTD-11104. EG\&G, Idaho Falls, Idaho.

Thiel, T. N. 1993. Decontamination and Decommissioning Plan for ARA-II. WM-ERP-92-016. Idaho National Engineering Laboratory, EG\& G, Idaho Falls, Idaho.

Contacts:

R. J. (Russ) Buckland, D\&D. (208) 526-9813.

Don Harrison, Database Management. (208) 526-7514.

Kip Archibald, Technology Development. 


\section{(INEL continued)}

Site: Materials Test Reactor (MTR)

D\&D Description: MTR is the oldest of the INEL test reactors; it began operation in 1952. MTR is located in building MTR-603, which contains the reactor structure and storage canal. The building is $39.6 \mathrm{~m}^{2}$. The MTR-603 canal is $2.4 \mathrm{~m}$ wide, $5.5 \mathrm{~m}$ deep, and extends $42.7 \mathrm{~m}$ eastward. Building MTR-603, and approximately 30 other buildings and structures, contain widespread, low-level contamination, much of which is associated with the concrete. As of 1993, a decision had not been made in regard to a preferred option for D\&D. A decision analysis report will be prepared in 1996.

Concrete Contamination:

Significance: the large volume of concrete associated with this facility and requirements for a remote method of $D \& D$ are primary concerns.

Extent: provided in the characterization study (Rolfe and Wills 1984).

Volume: $3,344 \mathrm{~m}^{3}$.

Rubble: $3,522 \mathrm{~m}^{3}$.

Contaminants: ${ }^{60} \mathrm{Co},{ }^{137} \mathrm{Cs},{ }^{90} \mathrm{Sr},{ }^{134} \mathrm{Cs}$

Technology Demonstrations: not known.

Technologies Under Consideration: see Table A.3.

Technologies Needed: the method for D\&D of the MTR vessel and components is of primary concern. The reactor core components are highly radioactive and require remote technologies.

Data and Studies Available: characterization study (Rolfe and Wills 1984).

Disposal Location: on site.

Decontamination Schedule:

Start date: prior to FY92 through FY2005.

Total treatment time: 8 years. 
(INEL MTR continued)

Current status: surveillance and maintenance activities are on-going.

Decontamination Cost: total estimated cost of $D \& D$ is $\$ 33,026,000$.

Comments: the MTR-605 Process Water Building was decontaminated and decommissioned in 1984 and the MTR-674 Plug Storage Facilities in 1983.

Clean-Up Criteria: DOE Order 5400.5 (U.S. DOE 1990). D\&D release criteria specific to INEL application were developed in 1986 (EG\&G 1986). Additional considerations exist for projects subject to CERCLA.

References and Contacts:

References:

Buckland, R.J., D. J. Kenoyer, and D. H. Preussner. 1993. INEL D\&D Long-Range Plan. Idaho National Engineering Laboratory, EG\&G, Idaho Falls, Idaho.

EG\&G. 1986. Development of Criteria for Release of INEL Sites Following D\&D. EGG-2400. EG\&G, Idaho Falls, Idaho.

INEL. 1994. Idaho National Engineering Laboratory Decontamination and Deconmissioning Technology Logic Diagram. EGG-WTD-1 1104. EG\&G, Idaho Falls, Idaho.

Rolfe, R. L., and E. L. Wills. 1984. Characterization of the MTR. WM-F1-83-016. 


\section{(INEL continued)}

Site: CFA-669 Hot Laundry

D\&D Description: this facility was constructed in 1950 to serve as the "hot" and "cold" laundry for INEL site contractors. The use of CFA-669 was discontinued in 1982 after the boiler exploded. CFA- 669 has nearly $4500 \mathrm{ft}^{2}$ of floor space. Approved D\&D is to remove and dispose of all hazardous and radiological contamination, demolish the remaining structure, and release the site for unrestricted use.

Concrete Contamination:

Significance: small volume of concrete and concrete rubble.

Extent: provided in characterization study (Kickhus 1992).

Volume: $20 \mathrm{~m}^{3}$.

Rubble: $74 \mathrm{~m}^{3}$.

Contaminants: gross alpha and gross beta, gamma from ${ }^{60} \mathrm{Co},{ }^{137} \mathrm{Cs},{ }^{125} \mathrm{Sb},{ }^{152} \mathrm{Eu},{ }^{154} \mathrm{Eu},{ }^{94} \mathrm{Nb}$.

Contact beta-gamma contamination ranged from 1,000 to $46,000 \mathrm{cpm}$ above background.

Technology Demonstrations: not known.

Technologies Under Consideration: see Table A.3.

Technologies Needed: see Table A.3.

Data and Studies Available: characterization study (Kickhus 1992).

Disposal Location: on site.

Decontamination Schedule:

Start date: FY92 through FY95.

Total treatment time: 3 years.

Current status: D\&D activities in progress.

Decontamination Cost: total estimated cost is $\$ 2,958,000$. 
(INEL CFA-669 continued)

Comments: none.

Clean-Up Criteria: DOE Order 5400.5 (U.S. DOE 1990). D\&D release criteria specific to INEL application were developed in 1986 (EG\&G 1986). Additional considerations exist for projects subject to CERCLA.

References and Contacts:

References:

Buckland, R.J., D. J. Kenoyer, and D. H. Preussner. 1993. INEL D\&D Long-Range Plan. Idaho National Engineering Laboratory, EG\&G, Idaho Falls, Idaho.

EG\&G. 1986. Development of Criteria for Release of INEL Sites Following D\&D. EGG-2400. EG\&G, Idaho Falls, Idaho.

INEL. 1994. Idaho National Engineering Laboratory Decontamination and Decommissioning Technology Logic Diagram. EGG-WTD-11104. EG\&G, Idaho Falls, Idaho.

Kickhus, K. J. 1992. Characterization and Decision Analysis for the Old Hot Laundry Facility (CFA-669). EGG-WM-10034.

Smith, D. L. 1992. D\&D Plan for CFA-669 Hot Laundry. EGG-WM-10125. 


\section{(INEL continued)}

Site: Engineering Test Reactor (ETR)

D\&D Description: the ETR first operated in 1957. The facility consists of a reactor building and approximately 14 support buildings and structures. Widespread, low-level contamination exists in most facility structures. A decision analysis has not been performed for the ETR; D\&D options have yet to be determined.

Concrete Contamination:

Significance: the reactor core components are highly radioactive. A large volume of contaminated concrete is associated with this facility.

Extent: provided in the characterization study (Kaiser et al. 1982).

Volume: $3370 \mathrm{~m}^{3}$

Rubble: $743 \mathrm{~m}^{3}$

Contaminants: ${ }^{137} \mathrm{Cs},{ }^{60} \mathrm{Co},{ }^{134} \mathrm{Cs}, \mathrm{Ag}$.

Technology Demonstrations: not known.

Technologies Under Consideration: see Table A.3.

Technologies Needed: see Table A.3.

Data and Studies Available: characterization study (Kaiser et al. 1982).

Disposal Location: on site.

Decontamination Schedule:

Start date: FY94 through FY2005.

Total treatment time: 11 years.

Current status: routine surveillance and maintenance.

Decontamination Cost: total estimated cost is $\$ 44,974,000$. 


\section{(INEL ETR continued)}

Comments: the ETR was deactivated and decontaminated immediately after its shutdown.

Clean-Up Criteria: DOE Order 5400.5 (U.S. DOE 1990). D\&D release criteria specific to INEL application were developed in 1986 (EG\&G 1986). Additional considerations exist for projects subject to CERCLA.

References and Contacts:

References:

Buckland, R.J., D. J. Kenoyer, and D. H. Preussner. 1993. INEL D\&D Long-Range Plan. Idaho National Engineering Laboratory. EG\&G, Idaho Falls, Idaho.

EG\&G. 1986. Development of Criteria for Release of INEL Sites Following D\&D. EGG-2400. EG\&G, Idaho Falls, Idaho.

INEL. 1994. Idaho National Engineering Laboratory Decontamination and Decommissioning Technology Logic Diagram. EG\&G, Idaho Falls, Idaho.

Kaiser L. L. 1982. Characterization of the ETR Facility. EGG-PR-5784. 


\section{A-55}

\section{(INEL continued)}

Site: TAN Test Support Facilities (TSF)

D\&D Description: TSF were used from 1952 to 1984. Most of these facilities are no longer in use for their original purpose and are scheduled for demolition the near future. All facilities have not been fully characterized to determine the appropriate D\&D method. The TAN TSF-3 concrete pad of TAN-604 was decontaminated and decommissioned in 1983. The TAN TSF Radioactive Liquid Waste Evaporator System (PM-2A) underwent D\&D in 1982.

Concrete Contamination:

Significance: contaminated concrete will be removed; the facility will be retained for future use.

Extent: not fully characterized at this time.

Volume: $354 \mathrm{~m}^{3}$

Contaminants: ${ }^{23+} \mathrm{U},{ }^{235} \mathrm{U},{ }^{236} \mathrm{U},{ }^{238} \mathrm{Pu},{ }^{239} \mathrm{Pu},{ }^{2+1} \mathrm{Am},{ }^{244} \mathrm{Cm},{ }^{90} \mathrm{Sr}$, and others.

Technology Demonstrations: not known.

Technologies Under Consideration: not known.

Technologies Needed: not known.

Data and Studies Available: see References.

Disposal Location: on site.

Decontamination Schedule:

Start date: 1993.

Total treatment time: unknown.

Current status: surveillance and maintenance, D\&D.

Decontamination Cost: total estimated cost is $\$ 4,193,000$. 


\section{(INEL TSF continued)}

Comments: none.

Clean-Up Criteria: DOE Order 5400.5 (U.S. DOE 1990). D\&D release criteria specific to INEL application were developed in 1986 (EG\&G 1986). Additional considerations exist for projects subject to CERCLA.

References and Contacts:

References:

Buckland, R.J., D. J. Kenoyer, and D. H. Preussner. 1993. INEL D\&D Long-Range Plan. Idaho National Engineering Laboratory. EG\&G, Idaho Falls, Idaho.

EG\&G. 1986. Development of Criteria for Release of INEL Sites Following D\&D. EGG-2400. EG\&G, Idaho Falls, Idaho.

INEL. 1994. Idaho National Engineering Laboratory Decontamination and Decommissioning Technology Logic Diagram. EG\&G, Idaho Falls, Idaho. 


\section{(INEL continued)}

Site: Idaho Chemical Processing Plant

D\&D Description: several inactive facilities require decontamination using remote and semiremote technologies.

Concrete Contamination:

Significance: not known.

Extent: $\sim 725,000 \mathrm{ft}^{2}$ of concrete surfaces require decontamination. Direct-contact techniques are planned for $\sim 10,000 \mathrm{ft}^{2}$; the remainder must be decontaminated by remote and semi-remote techniques.

Volume: not known.

Contaminants: radionuclides (not specified) in dry, solid form; some mixed wastes.

Technology Demonstrations: on-going demonstrations of chelation and surface abrasion.

Technologies Under Consideration: the anticipated methods are wet chemistry (chelation, extraction, corrosive removal) and destructive mechanical (scabbling, scraping, grinding, etc.).

Technologies Needed: not known.

Data and Studies Available: site-characterization and decision analysis reports (titles not specified) are available for many of the inactive ICPP facilities. Other characterization and feasibility studies are on-going (as of January 1995).

Disposal Location: on site.

Decontamination Schedule: FY95 through FY2001. Cost and schedule for particular sites are not yet available.

Start date: FY95.

Total treatment time: 7 years.

Current status: not known. 


\section{A-58}

\section{(INEL ICPP continued)}

Decontamination Cost: not yet estimated.

Comments: residual radionuclide contaminants tend to leach out of previously decontaminated concrete after several years of inactivity.

Clean-Up Criteria: to health-based release limits and ALARA considerations.

References and Contacts:

D.A. Peterson (208)526-7441 


\section{(INEL continued)}

Site: ICPP chloride removal system (CRS).

D\&D Description: WINCO is in the D\&D process of eight contaminated surplus facilities that have been identified by DOE ER. One of these facilities, CRS, is the first step in the larger D\&D effort of ICPP and hence, is the subject of various technology demonstrations.

Concrete Contamination:

Significance: not known.

Extent: not known.

Volume: not known.

Contaminants: U, Pu, Sr, Ce, Co, Eu, Am.

Technology Demonstrations:

1. scabbling by Pentek.

2. chemical processes by EET.

3. electroosmotic pulse technology by Dry-Tech.

Technologies Under Consideration: see Table A.3.

Technologies Needed: see Table A.3.

Data and Studies Available: see References.

Disposal Location: on site.

Decontamination Schedule:

Start date: not known.

Total treatment time: not known.

Current status: not known. 


\section{(INEL CRS continued)}

Decontamination Cost: not known.

Comments: past efforts produced large amounts of radioactive, sodium-bearing, liquid waste or secondary waste. Crushing methods resulted in high volumes of contaminated solid waste.

Clean-Up Criteria: same as other INEL sites. Note: The technology demonstrations at CRS were required to clean to free-release criteria of: (1) $<200 \mathrm{dpm}$ beta/gamma (smearable), (2) $<10 \mathrm{dpm}$ alpha (smearable), (3) $<100 \mathrm{cpm}>$ background beta/gamma (fixed), and (4) no detectable alpha (fixed).

References and Contacts:

References:

Archibald, Kip E. 1995. Concrete Decontamination Scoping Tests. Idaho National Engineering Laboratory. Idaho Falls, Idaho.

INEL. 1994. Idaho National Engineering Laboratory Decontamination and Decommissioning Technology Logic Diagram. EG\&G, Idaho Falls, Idaho.

Waite, Thorton H. 1992. Contamination and Decommissioning of a Small Surplus Facility. Idaho National Engineering Laboratory. Idaho Falls, Idaho.

Contacts:

Dennis Peterson, (208) 526-7441, (208) 526-4775 (fax) 


\section{Facility: Kansas City Plant}

Site: various buildings and equipment.

D\&D Description: as a result of the current effort to reduce floor space at the plant, a significant portion of the facility will be returned to the General Services Administration for other use. Some of the real estate is contaminated.

Concrete Contamination:

Significance: not known.

Extent: not known.

Volume: not known.

Contaminants: PCBs, petroleum hydrocarbons, chlorinated solvents.

Technology Demonstrations: EET, Inc., will demonstrate solvent technology (Tech-Xtract).

Technologies Under Consideration: not known.

Technologies Needed: not known.

Data and Studies Available: characterization data, feasibility studies (not specified).

Disposal Location: Emelle, Alabama, for large quantities.

Decontamination Schedule:

Start date: not known.

Total treatment time: not known.

Current status: $\mathrm{KCP}$ has only recently initiated a $\mathrm{D} \& \mathrm{D}$ program.

Decontamination Cost: not known.

Comments: none.

Clean-Up Criteria: not known.

References and Contacts:

D. E. Brown (816)997-4034 


\section{Facility: Lawrence Berkeley Laboratory}

Site: Bevalac

D\&D Description: thousands of blocks of concrete formerly used for lining and shielding; some are activated. Blocks range in size from $\sim 2 \mathrm{ft}$ up to $\sim 8 \mathrm{ft}$ on each side, weighing up to $60,000 \mathrm{lb}$ each. Some have to be characterized with respect to activity; others will be shipped to BNL to be reused for shielding; the remainder will go to ORR where they will be pulverized and recycled as waste burial boxes for contamination at ORR.

Concrete Contamination:

Significance: not especially significant; most of the activated concrete will be recycled or reused.

Extent: not known; "thousands" of blocks are stored on site.

Volume: estimated at $500,000 \mathrm{ft}^{3}$

Contaminants: activation products in concrete are ${ }^{60} \mathrm{Co}$ and isotopes of Eu; rebar contains ${ }^{60} \mathrm{Co}$.

Technology Demonstrations: none

Technologies Under Consideration: none, other than recycling and reuse. Concrete shipped to ORR will be pulverized and reused as aggregate in new concrete for waste burial boxes. Rebar in the concrete will be cut and ground into small "fibers" and reintroduced into the matrix as a strengthening material.

Technologies Needed: none.

Data and Studies Available: none.

Disposal Location: non-activated $(<20 \mathrm{pCi} / \mathrm{g})$ concrete will be separated for unrestricted release; blocks with surface activity $<2 \mathrm{nCi} / \mathrm{g}$ will be shipped to $\mathrm{BNL}$ for use as shielding; remaining, higher-activity concrete will be shipped to ORR and recycled as aggregate in waste burial boxes.

Decontamination Schedule: project began in FY95 and will continue another four years.

Current status: program is in progress. 


\section{(LBL continued)}

Decontamination Cost: free-release and concrete shipped to ORR costs are not known; estimated at $\$ 10 \mathrm{M}$ for the concrete shipped to BNL; most of the cost is for transportation.

Comments:

1. It would have cost more than $\$ 100 \mathrm{M}$ to characterize and dispose of the entire quantity. Exposure rate of the activated concrete is $\leq 1 \mathrm{mrem} / \mathrm{h}$ on the surface. Activation is 2 to 4 in. deep.

2. There is a concrete pad $10 \mathrm{ft} \times 10 \mathrm{ft} \times 18 \mathrm{in}$. contaminated with transformer oil containing very low level PCBs. Vacuum blasting was tried unsuccessfully. The process pushed the oil deeper into the concrete; when pressure returned to ambient, the oil seeped back to the surface. Detergent (Moxie Clean) was more successful.

3. Very small spills of radionuclides have occurred, usually from dropping a sample bottle. These were cleaned up by chipping the concrete where the spill occurred.

Clean-Up Criteria: $<20 \mathrm{pCi} / \mathrm{g}$ for free release, $<2 \mathrm{nCi} / \mathrm{g}$ for shipping to $\mathrm{BNL}$, no criteria for material shipped to ORR.

References and Contacts:

Mike Schoonover (510)486-6424

Roger Kloepping (510)486-7608

Robert Fox (510)486-7327 


\section{A -64}

\section{Facility: Los Alamos National Laboratory}

Site: not specified.

D\&D Description: various laboratories, one reactor, and approximately 40 small structures used for explosives work are scheduled for decommissioning within the next ten years. The volume of waste generated is the most significant issue.

Concrete Contamination:

Significance: not known.

Extent: concrete walls and floors, typically 12 in. thick, have low-level surface contamination. Scattered spill areas have contaminants absorbed into the concrete.

Volume: estimated at $6000 \mathrm{yd}^{3}$ over the next 3 to 4 years.

Contaminants: ${ }^{239} \mathrm{Pu}$ and ${ }^{235} \mathrm{U}$.

Technology Demonstrations: not known.

Technologies Under Consideration: traditional mechanical scabbling is currently being used. Solvent, microwave, and laser technologies are being examined but have not been applied at the site. Waste minimization by crushing and segregating the concrete is seriously being considered.

Technologies Needed: not known.

Data and Studies Available: not known.

Disposal Location: exploring disposal options at NTS and in Utah. The best option appears to be to remove the radionuclide contaminants and use the aggregate for on-site construction.

Decontamination Schedule: entire D\&D is scheduled for completion in ten years. Remediation activities began in 1994; two new projects should start in spring 1995.

Decontamination Cost: from $\$ 500,000$ to $\$ 1.5 \mathrm{M}$ per year.

Comments: LANL is also examining the long-range alpha detector for measurement of alpha contamination.

Clean-Up Criteria: not known. 
A- 65

(LANL continued)

References and Contacts:

Miguel Salazar (505)665-3056 


\section{Facility: Mound Plant}

Site: buildings WD, R, SW, T, 21, 38, HH.

D\&D Description: decontamination and demolition of buildings.

Concrete Contamination:

\begin{tabular}{|c|c|c|}
\hline Extent: & Site & Contamination, $\mathrm{ft}^{2}$ \\
\hline & $\overline{\mathrm{WD}}$ & 26,000 \\
\hline & $\mathrm{R}$ & 10,000 \\
\hline & SW & 41,000 \\
\hline & $\mathrm{T}$ & 50,000 \\
\hline & 21 & 4,000 \\
\hline & 38 & 20,000 \\
\hline & $\mathrm{HH}$ & 5,000 \\
\hline & Misc. & 5,000 \\
\hline & $\overline{\text { Total }}$ & $\overline{161,000}$ \\
\hline
\end{tabular}

Volume of rubble generated: 50,000 to $100,000 \mathrm{ft}^{3}$ (without waste-packaging volume).

Contaminants:

$\frac{\text { Site }}{\mathrm{WD}}$
$\mathrm{R}$
$\mathrm{SW}$
$\mathrm{T}$
21
38
$\mathrm{HH}$
Misc

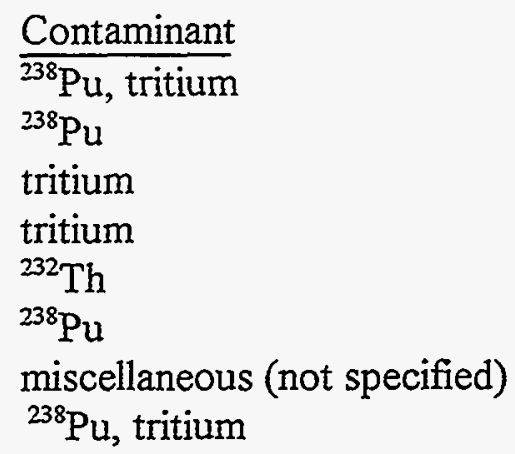

Technology Demonstrations: EET is pilot-testing a solvent-extraction method on a tilecovered floor. Two of the three applications have been completed; the decontamination results have been good. A third, final application will be performed after some bioassay requirements are met.

Technologies Under Consideration: for alpha emitters, acid leaching, removable paint, sandblasting, and various mechanical methods of removal have been tried. Overall, the best approach (if detergents don't work) has been the use of an enclosed, recycling abrasive blaster (Blast' N Vac).

Technologies Needed: not known. 


\section{A-67}

\section{(MND continued)}

Data and Studies Available: not known.

Disposal Location: an off-site landfill will be used for uncontaminated concrete; will continue to use NTS for low-level waste (LLW) disposal.

Decontamination Schedule: current, on-going D\&D program goes through 2010; this date will be extended much farther with the future addition of transition facilities.

Start date: not known.

Total treatment time: not known.

Current status: $D \& D$ is in progress.

Decontamination Cost: current inventory of surplus contaminated sites has a remaining estimated cost of $\sim \$ 335 \mathrm{M}$. Transition efforts at MND will probably add another $\$ 300 \mathrm{M}$.

Comments: decontamination of concrete is less of a problem than the free release by Health Physics of the remaining concrete after decontamination.

Clean-Up Criteria: DOE Order 5400.5 (U.S. DOE 1990).

References and Contacts:

William P. Davis (513)865-3513 


\section{Facility: Nevada Test Site}

Site: Nuclear Rocket Development Station (Engine Maintenance and Disassembly, Reactor Maintenance and Disassembly, Junior Hot Cell, Test Cell A, and Test Cell C); EPA Farm; Super Kukla Prompt Burst Reactor; Pluto Disassembly and Maintenance facility.

D\&D Description: D\&D has not yet begun at NTS; characterization of the sites starts in FY95 at the Junior Hot Cell and EPA Farm.

Concrete Contamination:

Significance: not known, but concrete contamination is a factor at all sites.

Extent: not known.

Volume: not known.

Contaminants: uranium and its longer-lived fission products at all but the EPA Farm; EPA Farm contaminants may include isotopes of $\mathrm{Pu}, \mathrm{Am}, \mathrm{Sr}$, and $\mathrm{Co}$.

Technology Demonstrations: none.

Technologies Under Consideration: none yet; chipping and scabbling were used for some concrete decontamination in the 1970s.

Technologies Needed: not known.

Data and Studies Available: none available for the D\&D program.

Disposal Location: on site for all LLW.

Decontamination Schedule: none; schedule will be established after sites are characterized.

Start date: not known; sites have not been characterized.

Total treatment time: not known.

Current status: characterization of the Junior Hot Cell and EPA Farm will begin in 1995.

Decontamination Cost: not known.

Comments: concrete decontamination and removal from several of the sites during the 1970 s eliminated the highly contaminated areas, but residual contamination still exists. 


\section{(NTS continued)}

Clean-Up Criteria: DOE Order 5400.5 (U.S. DOE 1990).

References and Contacts:

Janet Appenzeller-Wing (702)295-0461

Laura Tryboski (702)794-1712 


\section{Facility: Oak Ridge Reservation}

\section{General D\&D Description}

The scale of D\&D activities on the ORR is enormous, consisting of more than half of the DOE national D\&D program (MMES 1994). Facilities slated for D\&D on the reservation involve over 400 acres of enclosed space. The facilities currently in the ORR D\&D are at $\mathrm{Y}-12$, ORNL, and $\mathrm{K}-25$. The facilities are contaminated with a wide variety of substances including PCBs, asbestos, radioisotopes, chlorofluorocarbons, lubrication oils, and more. These facilities are constructed of concrete and, therefore, concrete decontamination technology development is sought to provide more efficient methods for the D\&D.

Because of the immense volumes of concrete that must ultimately be decontaminated and decommissioned, it was impossible to provide an exact inventory for ORR. The following sections describe some of the major D\&D projects and problems at $\mathrm{K}-25, \mathrm{Y}-12$, and ORNL.

\section{Site: K-25 Site}

D\&D Description: K-25 was formerly known as the Oak Ridge Gaseous Diffusion Plant, built to supply enriched uranium for nuclear weapons production. Eighty-two facilities are slated for D\&D at K-25. A detailed logic diagram that was developed to provide a planning document relating EM problems to potential technologies (ORNL 1993b).

Concrete Contamination:

Significance: K-25 contains 20 million $\mathrm{ft}^{2}$ of concrete surfaces potentially contaminated.

Extent: 139 acres of concrete floor, mostly surface contamination 1/16 in. or less. Depths vary in areas where organic compounds and water infiltrated.

Volume: not known.

Contaminants: U, ${ }^{99} \mathrm{Tc}, \mathrm{TRU}$.

Technology Demonstrations:

1. EK methods (Morgan et al. 1994)

2. Cryogenic pellet blasting (building $\mathrm{K}-25$ cell pilot project)

3. $\mathrm{CO}_{2}$ by non-destructive cleaning, 1994 (fair results) 
(ORR K-25 continued)

4. Perda OBG Technologies (soda blasting of contaminated concrete and metal surfaces). Proved to be labor-intensive and required secondary treatment of liquid waste streams. Also, required use of supplied breathing air.

Technologies Under Consideration or in Use:

Technologies discussed and considered in the logic diagram were (ORNL 1993b):

Mechanical surface methods

ultra-high-pressure water

shot blasting

scabblers/scarifiers

grit blasting

centrifuge cryogenic $\mathrm{CO}_{2}$ blasting

ice blasting

supercritical $\mathrm{CO}_{2}$ blasting

plastic pellet blasting

hand grinding, honing, scraping

automated grinding

concrete milling

explosive

Bulk decontamination methods

\author{
solvent extraction \\ incineration \\ biological \\ dry heat (bulk roasting) \\ chemical leaching \\ catalytic extraction process \\ vacuum (low pressure) \\ transmutation
}

Chemical surface cleaning methods

chemical foams

chemical gels

organic acid treatments

fluoroboric acid treatments

inorganic acid treatments

caustic detergent treatments

redox treatments

electropolishing

gas phase 


\section{(ORR K-25 continued)}

biological surface cleaning

UV/ozone

electromigration

chelation

Surface cleaning methods

compressed air cryogenic $\mathrm{CO}_{2}$ blasting

high-pressure water

superheated water

water flushing

steam cleaning

hand brushing

automated brushing

sponge blasting

hot-air stripping

dry heat (roasting)

solvent washing to remove radiological contamination

solvent washing to remove organic contamination

strippable coatings

vacuum cleaning

ultrasonic cleaning

Thermal surface removal methods

microwave scabbling

plasma torch

laser heating

laser etching and ablating

plasma surface cleaning

plasma etching/fluorination

flashlamp cleaning

Building 1401: D\&D personnel have been using the "squirrel" and "needle gun" for decontamination of concrete at this site. These devices clean at the rate of $12 \mathrm{ft}^{2} / \mathrm{h}$. Other mechanical devices used are the shot-blaster for floors and a forklift-mounted shot-blaster for walls. Both units are manufactured by NELCO in Oklahoma City. Approximately $1000 \mathrm{ft}^{2}$ have been cleaned up. Cost for the technology varies with locations, utilities accessibility, fixtures, protrusions, regulations, Health Physics, waste disposal, etc. It was noted that Health Physics costs were the largest component. For floor space of $6 \mathrm{ft} \times 4 \mathrm{ft}$, the waste is $<100 \mathrm{~g}$ because contamination is limited to depth of $0.5 \mathrm{~mm}$. $\mathrm{CO}_{2}$ blasting was tried and found to be extremely expensive and worker-unfriendly. The use of acids or solvents is not allowed at K-25 because of waste volume and waste disposal issues (mixed wastes). 


\section{(ORR K-25 continued)}

Technologies Needed:

1. more efficient concrete surface layer removal.

2. reduction of secondary waste from decontamination processes.

3. innovative systems for floor and wall decontamination.

4. decontamination of metals $(\mathrm{Ni}, \mathrm{Al}, \mathrm{Pb}$, and $\mathrm{Hg})$.

5. reduction of rubble waste.

Data and Studies Available: see References.

Disposal Location: waste generated by shot blasting is stored on site as dry LLW.

Decontamination Schedule: schedules are determined by risk factors and customer budgets. Cost estimates are made for each decontamination request; $\mathrm{ft}^{2}$ cost varies by contamination levels, obstructions in area, process knowledge, utility availability, and accessibility.

Start date: demonstrations in 1994 and 1995.

Total treatment time: not known.

Current status: characterization, planning, and some D\&D.

Decontamination Cost: total cost of all D\&D at K-25 estimated in the order of $\$ 8 \mathrm{~B}$. Disposal costs for LLW estimated at $\$ 600$ to $\$ 1500$ per drum.

Comments: accurate and complete characterization gives more precise cost estimates.

Process knowledge coupled with characterization will increase the precision of estimated clean-up costs.

Clean-Up Criteria: DOE orders; non-TRU release limits: $<5000 \mathrm{dpm} / \mathrm{cm}^{2}$ fixed beta; $<1000 \mathrm{dpm} / \mathrm{cm}^{2}$ transferrable gamma.

References and Contacts:

References:

Bailey, H. L., L. D. Charles, and R. K. Kibbe. 1992. Decontamination and decommissioning: K-25 pilot project. In proceedings of the 8th Annual Oak Ridge Model Conference, Waste Management and Environmental Restoration. Oak Ridge, Tennessee. 


\section{A-74}

\section{(ORR K-25 continued)}

Delozier, M. P., and J. Powell. 1991. Decommissioning of nuclear facilities by the U. S. DOE/Oak Ridge Field Office. In the 7th Annual DOE Model Conference on Waste Management and Environmental Restoration proceedings, Martin Marietta Energy Systems, Inc., Oak Ridge, Tennessee.

ORNL. 1993b. Oak Ridge K-25 Site Technology Logic Diagram. Volume 3, Technology Evaluation Data Sheets. Prepared for the Office of Technology Development, Oak Ridge National Laboratory, Oak Ridge, Tennessee.

MMES. 1994. Decontamination \& Decommissioning Activities on the Oak Ridge Reservation. Martin Marietta Energy Systems, Inc., Oak Ridge, Tennessee.

Morgan, I. L., W. D. Bostick, and W. D. Box. 1994. Electrokinetic Decontamination of Concrete. Martin Marietta Energy Systems, Inc., Oak Ridge, Tennessee.

\section{Contacts:}

Don Davis, (615) 241-3531.

Ronnie K. McMahan, Operations Division, (615) 576-9979. 
Facility: Oak Ridge National Laboratory

D\&D Description: sixteen facilities, comprising 50 separate areas, are slated for D\&D at ORNL. The D\&D challenge is one of complexity rather than scale due to the huge variety of radioactive elements and isotopes involved. ORNL has some of the most detailed information on concrete contamination in the DOE complex, documented in the ORNL Technology Logic Diagram (ORNL 1993a). This document is the source of most of the information in this evaluation.

The following ORNL facilities are in the D\&D program:

Building 3001 ORNL Graphite Reactor

Building 3005 Low-Intensity Test Reactor

Building 3042 Oak Ridge Research Reactor

Building 3087 Oak Ridge Research Reactor Heat Exchanger

Building 3505 Metal Recovery Facility

Building 3506 Waste Evaporator Facility

Building 3515 Fission Product Pilot Plan

Building 3517 Fission Product Development Laboratory Inactive Cells

Building 4507 High-Level Chemical Development Laboratory

Building 7500 Homogeneous Reactor Experiment

Building 7503 Molten Salt Reactor Experiment

Building 7852 Old Hydrofracture Facility

Building 9201-3 Mezzanine Storage Tank (Y-12)

Building 9201-3 Coolant Salt Technology Facility (Tritium Test Loop)

Building 9201-3 Molten Salt Corrosion Loop

Building 9419-1 Decontamination Facility

Shielded Transfer Tanks

ORNL isotope facilities scheduled for the D\&D program are:

Building 3026-C Krypton-85 Enrichment Facility

Building 3028 Alpha Powder Facility

Building 3029 Source Development Laboratory

Building 3030 Radioisotope Production Laboratory-C

Building 3031 Radioisotope Production Laboratory-D

Building 3033-A Actinide Fabrication Facility

Building 3038 Isotope Research Materials Laboratory

Building 3047 Radioisotope Development Laboratory

Building 3093 Storage Cubicle for Krypton

Building 3099 Storage Pad

Building 3118 Radioisotope Production Laboratory-H

Building 3517 Fission Products Development Laboratory

Building 7025 Tritium Target Facility 
(ORNL continued)

Building 3019-A Radiochemical Development Facility

Building 3019-B High-Level-Radiation Analytical Facility

Concrete Contamination: Table A.4 lists concrete, painted concrete, and high density concrete associated with these facilities.

Significance: highly significant.

Extent: see Table A.4.

Volume: not known.

Contaminants: see Table A.4.

Technologies Ünder Consideration: see Technology Logic Diagram (ORNL 1993a).

Technologies Needed:

1. more efficient concrete surface layer removal;

2. reduction of secondary waste from decontamination processes;

3. innovative systems for floor and wall decontamination;

4. decontamination of metals $(\mathrm{Ni}, \mathrm{Al}, \mathrm{Pb}$, and $\mathrm{Hg})$;

5. remote decontamination;

6. decontamination of rubble.

Data and Studies Available: characterization studies are available for most of the ORNL facilities, but are usually limited to surface radiological measurements.

Disposal Location: this is dependent on the type of contaminant and varies with location. See Technology Logic Diagram for further information (ORNL 1993a).

Decontamination Schedule: unknown.

Decontamination Cost: unknown.

Comments: none.

Clean-Up Criteria: Federal Facility Compliance Agreements (FFCA for ORR); DOE Order 5400.5 (U.S. DOE 1990). 
(ORNL continued)

References and Contacts:

References:

Delozier, M. P. 1991. Decommissioning of muclear facilities by the U. S. DOE/Oak Ridge Field Office. In the 7th Annual DOE Model Conference on Waste Management and Environmental Restoration proceedings, Martin Marietta Energy Systems, Inc., Oak Ridge, Tennessee.

ORNL. 1993a. Oak Ridge National Laboratory Technology Logic Diagram. Volumes 1,2, and 3. Oak Ridge National Laboratory, Oak Ridge, Tennessee.

Contacts:

Gary Person, (615) 574-9686.

John K. Williams, Martin Marietta Energy Systems, Inc., Oak Ridge National Laboratory, Health Sciences Research Division, P.O. Box 2008, Building 7503, Mail Stop 6382, Bethel Valley Road, Oak Ridge, Tennessee 37831-6382. Phone: (615) 574-7752; fax: (615) 574-1778. 
Table A.4. Concrete and associated contaminants at ORNL

\begin{tabular}{|c|c|c|c|}
\hline Substrate & Contaminant $^{a}$ & $\begin{array}{l}\text { Radiation } \\
\text { Level }^{b}\end{array}$ & Example \\
\hline High-density concrete & F.P., C.P., A.P. & $\mathrm{H}$ & HRT stiucture \\
\hline Concrete & 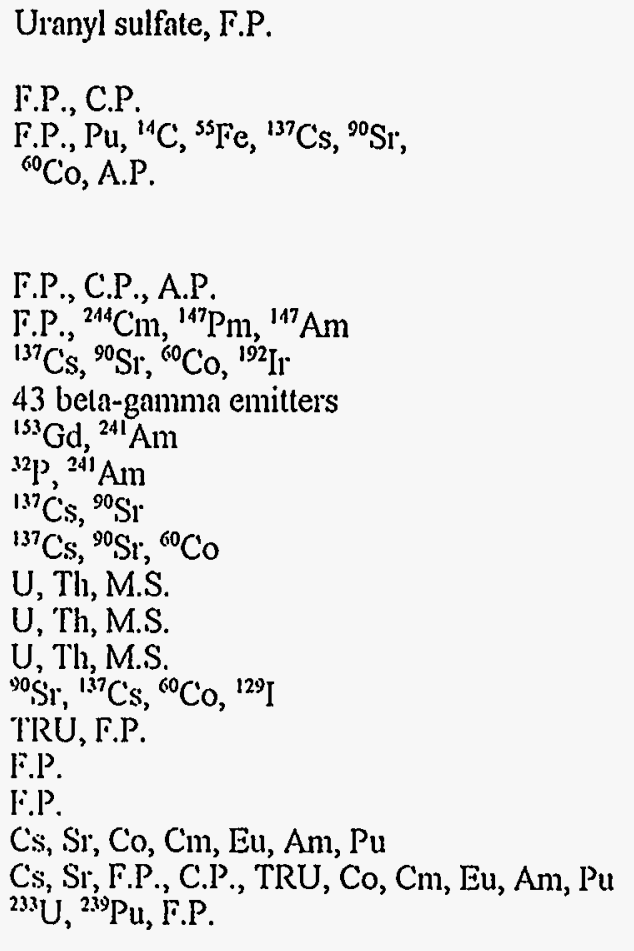 & $\begin{array}{l}\text { M } \\
H, M, I \\
M \\
M \\
L \\
L \\
L \\
M \\
M \\
M \\
L \\
L \\
V L \\
M \\
L \\
L \\
L \\
M \\
L . . \\
V L \\
M \\
M \\
M \\
H, M\end{array}$ & $\begin{array}{l}\text { Floor under and shield around evaporator in } \\
\text { bldg.7500 } \\
\text { ORR bilogical shield } \\
\text { Graphite Reactor bilogical shields } \\
\text { Graphite Reactor canal } \\
\text { Graphite Reactor duct work } \\
\text { Graphite Reactor stack } \\
\text { Slab supporting LITR components } \\
\text { Bldg. } 3028 \text { hot cell interiors } \\
\text { Bldg. } 3029 \text { hot cell interiors } \\
\text { Bldg. } 3030 \text { hot cell interiors } \\
\text { Bldg. } 3031 \text { hot cell interiors } \\
\text { Bldg. } 3032 \text { hot cell interiors } \\
\text { Bldg. } 3036 \text { floor } \\
\text { Bldg. } 3517 \text { hot cell interiors } \\
\text { Roofs of molten salt cells, bldg. } 9201-3 \\
\text { Floor of bldg. } 9419-1 \\
\text { First floor of molten salt cells, bldg. } 9201-3 \\
\text { Cell interiors in bldg. 3038 } \\
\text { Bldg. } 3505 \text { hot cell interiors } \\
\text { Bldg. } 3506 \text { hot cell interiors } \\
\text { Bldg. } 3515 \text { hot cell interiors } \\
\text { Bldg. } 3047 \text { hot cell interiors } \\
\text { Bldg. } 7852 \text { pump house pads } \\
\text { Bldg. } 3019 \text { hot cell interiors }\end{array}$ \\
\hline
\end{tabular}




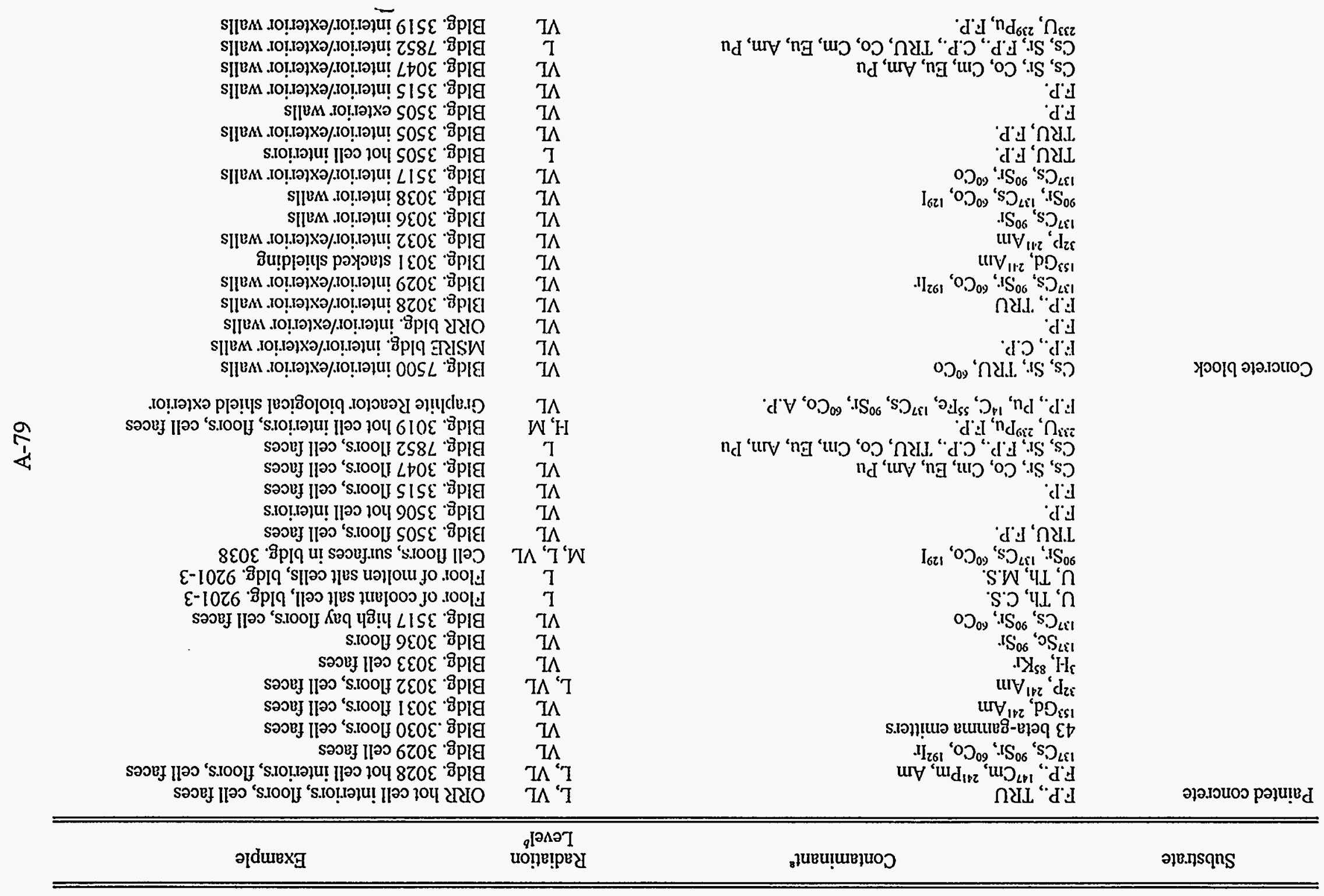

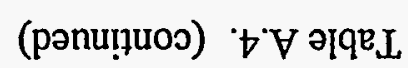


Table A.4. (continued)

\begin{tabular}{|c|c|c|c|}
\hline Substrate & Contaminant $^{\mathfrak{a}}$ & $\begin{array}{l}\text { Radiation } \\
\text { Level }^{b}\end{array}$ & Example \\
\hline Plaster/concrete block & $\mathrm{Cs}, \mathrm{Sr}, \mathrm{Co}, \mathrm{Cm}, \mathrm{Eu}, \mathrm{Am}, \mathrm{Pu}$ & VL & Bldg. 3047 interior walls \\
\hline Tiled concrete & 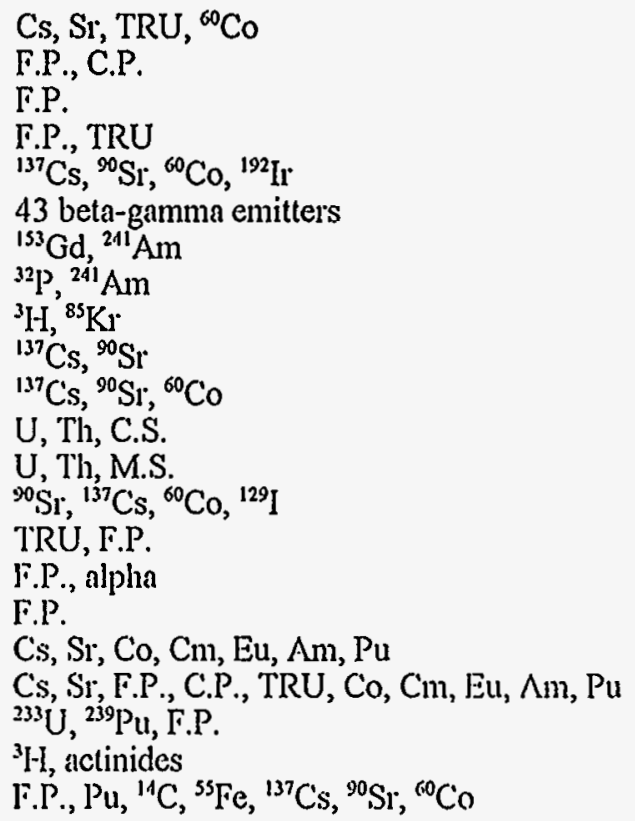 & 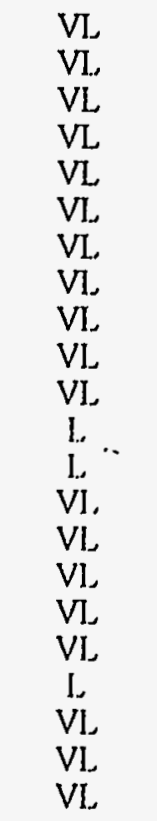 & $\begin{array}{l}\text { Bldg. } 7500 \text { floors } \\
\text { MSRE bldg. floors } \\
\text { ORR bldg. floors } \\
\text { Bldg. } 3028 \text { floors } \\
\text { Bldg. } 3029 \text { floors } \\
\text { Bldg. } 3030 \text { floors } \\
\text { Bldg. } 3031 \text { floors } \\
\text { Bldg. } 3032 \text { floors } \\
\text { Bldg. } 3033 \text { floors } \\
\text { Bldg. } 3036 \text { floors } \\
\text { Bldg. } 3517 \text { floors } \\
\text { Floor of coolant salt cell, bldg. } 9201-3 \\
\text { Floor of molten salt cells, bldg. } 9201-3 \\
\text { Bldg. } 3038 \text { floors } \\
\text { Bldg. } 3505 \text { floors } \\
\text { Bldg. } 3505 \text { floors } \\
\text { Bldg. } 3515 \text { floors } \\
\text { Bldg. } 3047 \text { floors } \\
\text { Bldg. } 7852 \text { floors } \\
\text { Bldg. } 3019 \text { floors } \\
\text { Bldg. } 7025 \text { floors } \\
\text { Crraphite Reactor bldg. floors }\end{array}$ \\
\hline
\end{tabular}

a F.P. = lission products; C.P. = corrosion products; A.P. = activation products; M.S. = molten salt; C.S. = coolant salt.

6 $\mathrm{H}=>100 \mathrm{R} / \mathrm{h} ; \mathrm{M}=1$ to $100 \mathrm{R} / \mathrm{h} ; \mathrm{L}=0.01$ to $1 \mathrm{R} / \mathrm{h} ; \mathrm{VL}=$ background to $0.01 \mathrm{R} / \mathrm{h}$. (Most values arc estimates.)

IHRT: Homogeneous Renctor Test

LITR: Low-Intensity Test Reactor

MSRE: Molten Salt Reactor Experiment

Source: ORNL 1993a 


\section{(ORR continued)}

\section{Site: Y-12 Plant}

$D \& D$ Description: the original mission of $Y-12$ was the separation of ${ }^{235} U$ from natural uranium by the electromagnetic separation process. Various operations have resulted in contamination of the facility since the Manhattan Project. One building at $\mathrm{Y}-12$ has been accepted into the D\&D program (Building 9201-4, known as Alpha-4). More than 20 other buildings have been identified as candidates for $D \& D$ but have yet to be accepted into the program. The BEMR data base identifies 76 buildings, five of which were declared surplus. The majority of these buildings are contaminated. There is on-going decontamination of concrete in Y-12 buildings, where missions have changed and contaminated areas need to be reused as office space. This on-going work is preceded by characterization and usually consists of surface cleaning. Scabbling techniques (shot blasting) are used to clean below surface.

Concrete Contamination:

Significance: not known.

Extent: D\&D at $Y-12$ is in the planning stages; it is difficult to assess the nature and extent of concrete contamination. Furthermore, on-going decontamination is often occurring in active buildings. Therefore, characterization and cleanup are often concurrent.

Volume: this information was not available; however, there are at least four buildings $(9201-4,9201-2,9202,9731)$ currently in the D\&D process, with 15 to 20 acres of floor space (according to information in the CROSSWALK data base), estimated total of $153,000 \mathrm{ft}^{2}$ of floor space. In Building $9401-4$, as much as 250 tons of elemental mercury may remain in the building, equipment, and foundation.

Contaminants: $\mathrm{Hg}, \mathrm{U},{ }^{232} \mathrm{Th}, \mathrm{PCBs}, \mathrm{Li}$.

Technology Demonstrations: in 1993, a chemical extraction technology was used to clean up PCB contamination from the concrete floors and walls of a manufacturing building. During the project, indirect evidence indicated that heavy metals and radionuclides were also being extracted from the surfaces. The chemical-based technology by EET, Inc. is being demonstrated for use on $\mathrm{Hg}$ and $\mathrm{Tc}$.

Technologies Under Consideration:

1. Hg roaster (preliminary stages)

2. high-pressure water jet

3. pelletized carbon dioxide. 


\section{(Y-12 continued)}

Technologies Needed:

1. technologies that decontaminate mercury;

2. more efficient concrete surface layer removal;

3. reduction of secondary waste from decontamination processes;

4. innovative systems for floor and wall decontamination;

5. decontamination of metals $(\mathrm{Ni}, \mathrm{Al}$, and $\mathrm{Pb})$.

Past Experience: Alpha-4 Building.

Data and Studies Available: information not available

Disposal Location: information not available

Decontamination Schedule: information not available

Decontamination Cost: not known.

Comments: one of the most significant contaminants at $Y-12$ is mercury, which penetrates concrete to greater depths than the radionuclide contamination. Since the radiological contamination is related to depleted and enriched uranium, there are no high exposure rates for workers during $\mathrm{D} \& \mathrm{D}$.

Clean-Up Criteria: information not available

References and Contacts:

References:

CROSSWALK data base.

Delozier, M. P., and J. Powell. 1991. Decommissioning of nuclear facilities by the U. S. DOE/Oak Ridge Field Office. In the 7th Annual DOE Model Conference on Waste Management and Environmental Restoration proceedings, Martin Marietta Energy Systems, Inc., Oak Ridge, Tennessee.

Contacts:

Susan Howell, (615)576-8260. Ms. Howell also recommended talking with Frank

Carrey and Dave Bethel for further information.

Bruce Walton, (615)241-2695; fax (615)576-8777

Mark Solenberger (615)241-2695 


\section{Facility: Paducah Gaseous Diffusion Plant}

Site: buildings $\mathrm{C}-340$ and $\mathrm{C}-410$ have been accepted for $\mathrm{D} \& \mathrm{D}$.

D\&D Description: characterization for D\&D has not yet begun. The facility contains four process buildings and numerous support facilities that will eventually be scheduled for D\&D.

Concrete Contamination:

Significance: not known.

Extent: total extent is unknown. The two buildings currently accepted for $D \& D$ comprise approximately $260,000 \mathrm{ft}^{2}$.

Volume: not known. An estimated 1,786,000 tons of structural concrete are potentially contaminated.

Contaminants: uranium, some TRU, PCBs, chromates, lead paint.

Technology Demonstrations: none.

Technologies Under Consideration: PGDP will use the K-25 Site Technology Logic Diagram for D\&D (ORNL 1993b). Technologies currently in use at PGDP include:

1. Chemical

boric acid

soda ash solutions

household 409 solution

strippable coatings

2. Physical

ultra-high-pressure water jetting

steam cleaning

glass bead blasting

alumina grit blasting

shot blasting

scarifying

HEPA vacuums

Technologies Needed: not known. 


\section{(PGDP continued)}

Data and Studies Available: not known.

Disposal Location: some on-site disposal is available at a permitted landfill, but most D\&D waste will need to be shipped off site. Current disposal options include a Toxic Substances Control Act incinerator; Envirocare, Clive County, Utah; HANF; and Scientific Ecology Group. Future options under consideration include NTS, the mixed-waste treatment facility at ORR, Aptus, and Rollins Environmental Services.

Decontamination Schedule: not known. Only two buildings are currently accepted for D\&D.

Start date: not known.

Total treatment time: cost estimate is projected through the year 2016, with D\&D scheduled for completion by 2030.

Current status: pre-D\&D characterization has not yet begun.

Decontamination Cost: $\$ 470 \mathrm{M}$ through the year 2016; total cost has not been estimated.

Comments: process building under roof: 74 acres.

Clean-Up Criteria: not known; basic criterion is $35 \mathrm{pCi} / \mathrm{g}$ for uranium in soil. Acceptable activity levels for release were created for scrap metal but also apply to concrete:

Transferable: $<20 \mathrm{dpm} / 100 \mathrm{~cm}^{2}$ alpha, $<1000 \mathrm{dpm} / 100 \mathrm{~cm}^{2}$ beta

Fixed: $<300 \mathrm{dpm} / 100 \mathrm{~cm}^{2}$ alpha, $<5000 \mathrm{dpm} / 100 \mathrm{~cm}^{2}$ beta

References and Contacts:

Steve Davis (502)441-5066; fax (502)441-5064. 


\section{Facility: Portsmouth Gaseous Diffusion Plant (PORTS)}

Site: building $705 \mathrm{~A}$.

D\&D Description: D\&D will take place in three phases: (1) remove equipment and decontaminate building, (2) demolish building, and (3) remediate soil.

Concrete Contamination:

Significance: not known.

Extent: not known; characterization for D\&D has not begun.

Volume: not known.

Contaminants: isotopes of uranium; possibly some technetium and TRU.

Technology Demonstrations: EET, Inc., used a chemical extraction process involving three applications of TechXtract. Product was applied to an epoxy-coated concrete slab contaminated with beta and gamma radiation. Contaminant removal was not as effective as hoped because the radionuclides were either under or bonded to the epoxy.

Technologies Under Consideration: none yet; the D\&D program is in the planning stage. Technologies will be considered based on the findings from Phase 1.

Technologies Needed: not known; areas of contaminated concrete have not been characterized.

Data and Studies Available: none.

Disposal Location: temporarily stored on site; ultimate disposal area is not known, but possibly off site at HANF or Envirocare, Clive County, Utah.

Decontamination Schedule: field work for bldg. 705A scheduled to begin in April 1995, Phase 3 to be completed in early 1996.

Decontamination Cost: not known.

Comments: none.

Clean-Up Criteria: not established, but the clean-up levels will comply with DOE Order 5400.5 (U.S. DOE 1990). 
(PORTS continued)

References and Contacts:

Bill Schloesslin (614)897-4374

Doug Davenport (614)897-3261 


\section{Facility: Rocky Mountain Arsenal}

Site: concrete building. Although Rocky Mountain Arsenal is not a DOE site, an evaluation was completed to disclose the innovative technology selection at the site.

D\&D Description: concrete building $52 \mathrm{ft} \times 16 \mathrm{ft} \times 8 \mathrm{ft}$, all but top $2 \mathrm{ft}$ is underground; building was contaminated with chemical agent mustard (mustard gas).

Concrete Contamination:

Significance: could not dispose off site; must decontaminate on site.

Extent: chemical agent mustard had partially permeated the building walls and had penetrated the entire thickness of the floor ( $24 \mathrm{in}$.) and contaminated underlying soil.

Volume: not known.

Contaminants: chemical agent mustard.

Technology Demonstrations: not known.

Technologies Under Consideration: technology selected was hot gas decontamination. Hot gas $\left(700-800^{\circ} \mathrm{F}\right)$ was introduced into the building; 117 thermocouples were installed to monitor temperature in the walls and floor. When all thermocouples had heated to $350^{\circ} \mathrm{F}$, temperature was maintained for $24 \mathrm{~h}$, then allowed to cool. Contaminant was vented through an exhaust duct and burned at $2000^{\circ} \mathrm{F}$ in an afterburner.

Technologies Needed: none

Data and Studies Available: technical report will be available in March 1995; contact: Wayne Sisk (Aberdeen Proving Ground) (410)612-6851. Technical reports are available for a previous technology demonstration at Cornhusker Army Ammunition Plant, Nebraska.

Disposal Location: burned on site.

Decontamination Schedule: not applicable.

Start date: not applicable.

Total treatment time: 5 weeks: 15 days to heat, $24-\mathrm{h}$ "soak" time, 18 days to cool.

Current status: not known. 


\section{A- 88}

(Rocky Mountain Arsenal continued)

Decontamination Cost: $\$ 5.2 \mathrm{M}$ for the entire project.

Comments: this was a technology demonstration. Hot gas has also been used at other facilities for decontamination of explosives-contaminated concrete. More demonstrations are being planned.

References and Contacts:

Wayne Sisk (Aberdeen Proving Ground) (410)612-6851 


\section{Facility: Rocky Flats Environmental Technology Site}

Site: buildings 371, 374, 444, 447, 707, 771, 774, 776, 777, 779, 881, 886, and 901.

D\&D Description: two small pilot projects are currently in progress; $D \& D$ program is in the planning stages for eventual ER of all 16 OUs. Plans for concrete D\&D call for removal of surface contaminants.

Concrete Contamination:

Significance: not known.

Extent: not known; characterization is just beginning. Of approximately 140 buildings in the RFETS inventory, 116 have been identified as contaminated; 13 (listed above) are scheduled for $\mathrm{D} \& \mathrm{D}$.

Volume: not known.

Contaminants: uranium, plutonium, asbestos, $\mathrm{PCBs}$, chemicals (not specified).

Technology Demonstrations: needle scabbling; a pilot project was successfully completed using a dustless decontamination system by Pentek. Strippable coating on glove boxes is in progress.

Technologies Under Consideration: scabbling has been used successfully in the past and is planned for future concrete $\mathrm{D} \& \mathrm{D}$. $\mathrm{CO}_{2}$ blaster (dry ice) has been tried in the past, but was not satisfactory due to the size and mobility of equipment. Method was physically tiring for workers, was expensive, and worked better on metal than on concrete. It is being considered for permanent installation in the Advanced Size Reduction Facility.

Technologies Needed: see demonstrations above.

Data and Studies Available: internal reports; contact: Tom Bourgeois (303)966-8020.

Disposal Location: hazardous waste is shipped off site; LLW and low-level mixed wastes (LLMW) are treated and stored at RFETS and are awaiting shipment for disposal at NTS. The use of commercial facilities for disposal of LLW and LLMW is being considered as an option to disposal at NTS; this would require a waiver to certain requirements in DOE Order 5820.2A (U.S. DOE 1988).

Decontamination Schedule: characterization of high-priority locations scheduled for D\&D is in progress and should be completed in 1995; D\&D is in the planning stages.

Decontamination Cost: not yet available. 


\section{(RFETS continued)}

Comments: after operators became familiar with the Pentek equipment, the rate of concrete decontamination was about $30 \mathrm{ft}^{2} / \mathrm{h}$. The equipment used cost less than $\$ 40,000$ and required no modification.

Clean-Up Criteria: clean up to $<250 \mathrm{cpm} / 100 \mathrm{~cm}^{2}$ alpha.

References and Contacts:

References:

Simmons, Michael. 1994. Decontamination of radioactive concrete: A permanent solution that's RCRA friendly. Radwaste Magazine, January 1994, pp. 25-29.

Contact:

Chuck Reed (303)966-3688

Chuck Baldwin (303)966-4008 
Facility: RMI Titanium, Inc. (RMIT)

Site: RMI Decommissioning Project (RMIDP)

D\&D Description: the primary function of RMIT from 1962 until 1988 was the extrusion and closed-die forging of depleted, normal, and slightly enriched metallic uranium as an intermediate step in the production of nuclear fuel elements for use in DOE plutonium production reactors at HANF and SRS. Current activities at the plant are focused on environ-mental restoration and $D \& D$ for eventual release for unrestricted use. The floors of all 25 facilities at RMIDP are concrete, generally $20 \mathrm{ft} \times 20 \mathrm{ft}$ slabs separated by expansion joints. Surveys have found minor removable contamination ( $<5000 \mathrm{dpm})$, fixed contamination ranging from $10,000 \mathrm{dpm}$ on the general floor spaces to $100,000 \mathrm{dpm}$ in the expansion joints and equipment footings, and up to $1,000,000 \mathrm{dpm}$ in the floor drains. The assumption that contamination is restricted to the top 1 in. of concrete will be confirmed by coring. It is likely that contamination will be found at greater depths where damage has occurred from fissures, acid weakening, and stress.

Concrete Contamination:

Significance: not known.

Extent: see D\&D description.

Volume: approximately $15,000 \mathrm{ft}^{3}$ of contaminated concrete will require disposal.

Contaminants: mainly ${ }^{2.35} \mathrm{U}$; inputs to drains contain a contaminated sludge from acid splashes, oil, grease, and water.

Technology Demonstrations: see Table A.5.

Technologies Under Consideration: present work plans call for scabbling and vacuuming the floors to remove contamination to depth. Chemical, mechanical, and electrical technologies are being investigated for comparison to the planned activities (see Table A.5). New technologies are being evaluated on the basis of reductions of cost and schedules for the project.

Technologies Needed: not known.

Data and Studies Available: see References. 
Table A.5. Status of technology demonstrations at RMIT

\begin{tabular}{|c|c|c|}
\hline Technology; Vendor & RMIDP Activity & Status \\
\hline $\begin{array}{l}\text { Flash lamp system for } \\
\text { removing contaminated } \\
\text { coatings; Polygon, Inc. }\end{array}$ & $\begin{array}{l}\text { Demonstrated in September } \\
\text { 1994. }\end{array}$ & $\begin{array}{l}\text { Test reported in January } \\
1995 \text {; possible follow-up test } \\
\text { using modified flashlamp } \\
\text { head in } 1995 \text {. }\end{array}$ \\
\hline $\begin{array}{l}\text { Contamination survey } \\
\text { robot; ORNL }\end{array}$ & $\begin{array}{l}\text { Developed proposal for } \\
\text { testing the robot at RMIT. }\end{array}$ & $\begin{array}{l}\text { Robot navigation system is } \\
\text { being modified; scheduled to } \\
\text { be available for testing at } \\
\text { RMI in mid- } 1995 \text { pending } \\
\text { DOE approval to proceed. }\end{array}$ \\
\hline $\begin{array}{l}\text { Laser ablation for } \\
\text { surface } \\
\text { decontamination; } \\
\text { F2 Associates. } \\
\end{array}$ & $\begin{array}{l}\text { F2 is continuing develop- } \\
\text { ment of a prototype with a } \\
\text { larger head and delivery } \\
\text { system. }\end{array}$ & $\begin{array}{l}\text { Parsons will propose a test at } \\
\text { RMIDP in mid } 1995 \text {. }\end{array}$ \\
\hline $\begin{array}{l}\text { Solvent application; } \\
\text { EET, Inc. }\end{array}$ & $\begin{array}{l}\text { Draft proposal for testing in } \\
\text { a contaminated area has } \\
\text { been submitted to RMIT } \\
\text { management for review. }\end{array}$ & $\begin{array}{l}\text { Continue proposal } \\
\text { development for planned } \\
\text { demonstration in mid-1995. }\end{array}$ \\
\hline $\begin{array}{l}\text { Concrete } \\
\text { decontamination }\end{array}$ & $\begin{array}{l}\text { Hosted a visit by the national } \\
\text { coordinators of the EM- } 50 \\
\text { Program for Contaminated } \\
\text { Concrete Recycle. }\end{array}$ & $\begin{array}{l}\text { Explore possibilities for } \\
\text { hosting a demonstration of } \\
\text { concrete decontamination } \\
\text { technology under the } \\
\text { program. }\end{array}$ \\
\hline $\begin{array}{l}\text { Soft media cleaning } \\
\text { system; Gencor/Aerojet. }\end{array}$ & $\begin{array}{l}\text { Aerojet visited the site and } \\
\text { has prepared a proposal for } \\
\text { testing; the proposal should } \\
\text { be available the week of } \\
2 / 13 / 95 \text {. }\end{array}$ & $\begin{array}{l}\text { Reviewing the proposal from } \\
\text { the vendor; considering for } \\
\text { testing at this site. }\end{array}$ \\
\hline $\begin{array}{l}\text { Ice blast cleaning; } \\
\text { ARC, Inc. }\end{array}$ & Demonstration complete. & $\begin{array}{l}\text { Considering for application } \\
\text { to D\&D of RMIT. }\end{array}$ \\
\hline
\end{tabular}




\section{(RMIT continued)}

Disposal Location: contaminated concrete will be disposed of at the NTS or at Envirocare, Clive County, Utah. Uncontaminated concrete will be crushed to rubble smaller than 1 in. and used as clean backfill after remediation. The ability to perform on-site disposal will depend on obtaining permits from the Ohio EPA and the Ashtabula County Health Department.

Decontamination Schedule:

Start date: not known.

Total treatment time: not known.

Current status: the schedule for completing the RMIDP has not been determined.

Current efforts are being directed toward developing an alternate decommissioning project cost and technical baseline to be submitted to DOE.

Decontamination Cost: total cost has not been estimated. Disposal rates are $\$ 21 / \mathrm{ft}^{3}$ at NTS and $\$ 16 / \mathrm{ft}^{3}$ at Envirocare.

Comments: none.

Clean-Up Criteria: Regulatory Guide 1.86 (U.S. AEC 1974) and NUREG 1500 (U.S. NRC 1994b).

References and Contacts:

References:

Regulatory Guide 1.86: Reactor License Termination (U.S. AEC 1974).

NUREG 5849: Manual for Conducting Radiological Surveys in Support of License Termination.

NRC 3.65: Decommissioning Plan Format

NUREG 1500: Release Criteria (U.S. NRC 1994b)

NRC BTB: Site Characterization for Decommissioning 
(RMIT continued)

10 CFR 20

10 CFR 40

40 CFR 264

DOE Order 5820.2A/2B (U.S. DOE 1988)

NVO-325

Contact:

Scott Fultz (216)993-2088 


\section{Facility: Savannah River Site}

Site: 5 production reactors (4 surplus), fuel fabrication facility, 2 canyons, surplus development reactor, 51 high-level waste tanks, defense waste processing facility (DWPF), numerous support buildings.

D\&D Description: D\&D is on-going. Eleven surplus buildings were dismantled and removed in FY94. Currently the original tritium product recovery facility is undergoing D\&D as well as initial D\&D for the Heavy Water Components Test Reactor.

Concrete Contamination:

Significance: not known.

Extent: reactor buildings, including spent-fuel basins, have some surface concrete contamination. Reprocessing canyons have major concrete contamination from spills of radioactive process solutions. Plutonium-processing lines have alpha contamination inside the process enclosures, although concrete involvement is minimal.

Volume: not known.

Contaminants: reactor spent-fuel basins contain fission products, contaminated sludge (not specified), and corrosion products (not specified). Fuel-reprocessing canyons have isotopes associated with dissolved, aluminum-clad spent fuel, uranium, plutonium, and fission products.

Technology Demonstrations: no integrated demonstrations under the EM-50 Program are on-going at this time. The Savannah River Technology Center has an on-going program to evaluate promising decontamination methods in field applications. Contact is Tom Butcher (803) 725-5810.

Technologies Under Consideration: most conventional technologies have been used.

Technologies Needed: no new technology needs have been identified at this time.

Data and Studies Available: all decontamination jobs and studies have been documented. Contacts are Tom Butcher (803) 725-5810, and Bob Smith (803) 557-2662.

Disposal Location: on site. 


\section{(SRS continued)}

Decontamination Schedule:

Start date: decontamination of the tritium recovery facility will begin in FY95 and be finished in FY96.

Total treatment time: not known.

Current status: no other major decontamination projects have been funded and scheduled at this time.

Decontamination Cost: $\mathrm{D} \& \mathrm{D}$ program is not yet sufficiently advanced to estimate costs.

Comments: none.

Clean-Up Criteria: not specified.

References and Contacts:

Bill Austin (803)644-5056

Tom Butcher (803)725-5810

Ron J. Hinds (803)725-5422

H.P. Olson (803)644-5122

Rich Hanes (803)725-5811

Bob Smith (803)557-2662 


\section{Facility: Weldon Spring Site Remedial Action Project (WSR)}

Site: not known.

D\&D Description: demolition, remediation, and disposal of uranium refining process buildings, process equipment, support facilities, and former disposal areas.

Concrete Contamination:

Significance: not known.

Extent: building foundations and slabs are contaminated with uranium and thorium compounds; elemental mercury was present in some areas.

Volume: not known.

Contaminants: U, Th, Hg.

Technology Demonstrations: not known.

Technologies Under Consideration: technologies used to date include high-pressure washers to reduce removable radioactive constituents and Nilfisk vacuums to collect metallic mercury. A commercially available product (not specified) was used to stabilize residual mercury as a salt.

Technologies Needed: none.

Data and Studies Available: building demolition specifications.

Disposal Location: most concrete will be buried on site; some will be crushed and hauled off site for release.

Decontamination Schedule: not known.

Start date: not known.

Total treatment time: not known.

Current status: not known.

Decontamination Cost: has not yet been separated from other costs.

Comments: there is a ROD through CERCLA. Clean-up standard for uranium is $200 \mathrm{pCi} / \mathrm{g}$ (same as for soil). Off-site ALARA clean-up standard is $30 \mathrm{pCi} / \mathrm{g}$. 


\section{A-98}

(WSR continued)

Clean-Up Criteria: $200 \mathrm{pCi} / \mathrm{g}$ for uranium (same as criterion for soil). Off-site ALARA cleanup standard is $30 \mathrm{pCi} / \mathrm{g}$.

References and Contacts:

Ken Lawver (314)441-8978

Neil DeYong (314)441-8086 ext. 3120 


\section{Facility: West Valley Demonstration Project (WVDP)}

This facility has performed concrete D\&D at numerous other on-site locations. Information specific to D\&D of the Chemical Process Cell was taken from a document provided by West Valley Nuclear Services Company, Inc. (Meigs 1987).

Site: Chemical Process Cell (CPC).

D\&D Description: D\&D was accomplished between January 1985 and March 1987. Preparatory work included D\&D of the Equipment Decontamination Room (EDR), the Chemical Crane Room (CCR), and the Scrap Removal Room. The CPC was decontaminated by removal of all jumpered piping and 11 vessels, vacuuming the cell floor, and decontaminating the ceiling, walls, and floors. Three 22.5-ton concrete neutron absorbers were cut and removed. All work was performed remotely using overhead cranes and an electromechanical manipulator.

Concrete Contamination:

Significance: not known.

Extent: initial area dose rate in the CPC ranged from 12 to $56 \mathrm{R} / \mathrm{h}$; smearable beta contamination exceeded $10^{9} \mathrm{dpm} / 100 \mathrm{~cm}^{2}$.

Estimated curie content of waste removed from the CPC:

\begin{tabular}{lc} 
Isotope & Estimated Curies \\
\cline { 2 - 2 }${ }^{137} \mathrm{Cs}$ & 245 \\
${ }^{90} \mathrm{Sr}$ & 235 \\
${ }^{241} \mathrm{Am}$ & 5 \\
$\mathrm{Pu}$ (total) & 212
\end{tabular}

Volume: total volume of primary decommissioning waste was over $30,000 \mathrm{ft}^{3}$; an additional $7800 \mathrm{ft}^{3}$ of secondary waste was generated.

Contaminants: ${ }^{137} \mathrm{Cs},{ }^{917} \mathrm{Sr},{ }^{2+1} \mathrm{Am}, \mathrm{Pu}$.

Technology Demonstrations: not known.

Technologies Under Consideration: technology employed in this project involved a staged sequence of vacuuming, foaming with alkaline detergent, rinsing with water at $700 \mathrm{psi}$ and $138^{\circ} \mathrm{C}$, foaming with $0.1 \mathrm{M} \mathrm{HNO}_{3}$, and another high-pressure hot water rinse. Remaining contamination was removed with high-pressure water abrasive-jet cutting. 


\section{(WVDP continued)}

Technologies Needed: not known.

Data and Studies Available: see References.

Disposal Location: on site.

Decontamination Schedule:

Start date: January 1985.

Total treatment time: 2 years.

- Current status: D\&D of the CPC was completed in March 1987.

Decontamination Cost: Labor

$\$ 2,025,077$

\begin{tabular}{lr} 
Materials and Supplies & $1,705,397$ \\
\hline Total & $\$ 3,730,474$
\end{tabular}

Comments:

Lessons learned:

1. Tool power cabling and hoses were significant impediments to work. A cable and hose handling system could have saved many manned entries into the CCR and EDR to repair broken cables and hoses.

2. A decontamination pass prior to equipment removal would have reduced exposure during waste handling and decreased the contamination control concerns significantly. Sampling of high-pH decontamination solutions that had come in contact with fissile materials indicates there is no criticality concern as long as slab geometries are maintained until the solids have settled.

3. An on-bridge video system would be extremely helpful during remote $D \& D$ work.

4. A mock-up electromechanical manipulator that would allow testing of all manipulator-held tools could help to minimize rework of equipment in contaminated areas, thereby reducing exposure and saving time.

5. An abrasive saw has proven to be a useful manipulator-held tool. 


\section{(WVDP continued)}

6. The addition of one set of master-slave manipulators to perform tasks that the electromechanical manipulator could not perform, such as replacement of saw blades, could have reduced worker exposure and saved a significant amount of time.

7. A transfer port for small equipment would reduce manned entry requirements.

8. Development work is needed on remote-vacuuming systems.

9. High-pressure water cutting and decontamination equipment has proved to be very helpful.

10. Outside storage of waste packages exceeding $1 \mathrm{R} / \mathrm{h}$ must be evaluated for "sky shine" potential, and adequate measures must be preplanned to keep storage area dose rates to an acceptable level.

Clean-Up Criteria: the following target levels were established before D\&D began:

1. $<10 \mathrm{mR} / \mathrm{h}$ general area dose rate or ALARA

2. reduce smearable contamination to $<200 \mathrm{dpm} / 100 \mathrm{~cm}^{2}$ beta and $<20 \mathrm{dpm} / 100 \mathrm{~cm}^{2}$ alpha

Contamination measured after completion of D\&D:

1. smearable, walls: $50,000-300,000 \mathrm{dpm} / 100 \mathrm{~cm}^{2}$ beta

2. smearable, floor: $100,000-950,000 \mathrm{dpm} / 100 \mathrm{~cm}^{2}$ beta

3. dose rates from $250-1200 \mathrm{mR} / \mathrm{h}$ gamma

References and Contacts:

References:

Meigs, R.A. 1987. Decontamination and Decommissioning of the Chemical Process Cell (CPC). DOE/NE/44139-41. West Valley Nuclear Services Company, Inc., West Valley, New York.

Contacts:

Dan Burke (716)942-4248

Dana Pezzimenti (716)942-4321

Don Sawyer (716)942-4333

Peter Vlad (716)942-4809 
,

เ 
APPENDIX B

DATA BASE INFORMATION

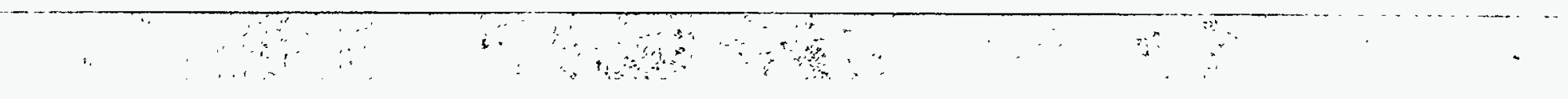





\section{Introduction}

SFIA data base

Table B. 1 is a listing of selected facilities from the SFIA data base, which holds over 20,000 records and, therefore, was filtered for information pertinent to this study. The filters to obtain the 211 records used in the observations in Sect. 2 were:

TYPE Limits the search to buildings (defined as fixed roof structures used for housing people, material, and/or equipment).

GROUPS Includes groups $1,2,3$, and 4 defined below.

Group 1: Process-contaminated buildings/structures that have been officially designated surplus by the cognizant Secretarial Officer by official notification to EM-1. By placing a structure in Group 1, EM will assume an official declaration of "surplus" has been made, therefore making the building eligible for transfer. EM will not consider a building/structure for transfer until it is placed in Group 1.

Group 2: All buildings/structures with one or more of the following characteristics:

1. no mission;

2. no funding;

3. orphan: the building/structure has no program/owner and has not been formally accepted by the site landlord; .

4. abandoned: has an owner but is left unattended with essentially no surveillance and maintenance activities. Group 2 is intended to be a temporary holding area for buildings/structures that have not been declared surplus but probably should be.

Group 3: All buildings with one or more of the following characteristics:

1. no mission projected beyond FY98;

2. declining budget, defined as a greater than $50 \%$ reduction over a 5 -year period;

3. current funding is solely dedicated to surveillance and maintenance activities. 


\section{B-2}

Group 4: A "watch list" of process-contaminated buildings/structures that, although not yet candidates for surplus, appear to have the potential of becoming surplus based on a continued trend of declining funding and mission.

RCANY Identifies whether or not there is confirmed radiological contamination at the facilities. This field can be $Y, N$, or $U$. The 211 records are those buildings that are confirmed (Y).

Because this project is focused on radiological contaminants, non-radiological contaminates were not filtered. In addition to not being thoroughly characterized, non-radiological contaminants may pose very specific decontamination situations (such as mixed waste) that are beyond the scope of this project.

The above procedure limited the data base to buildings that have a high potential of containing contaminated concrete and would be likely candidates for D\&D operations in the next decade. The data base filtered out buildings that did not have complete contaminant information (EM40 and EM-60 sites).

The SFIA data base was used to provide an overview of specific contaminants occurring at DOE facilities (Sect. 2.3). Although square footage of buildings was provided in the data base, there was no indication of how much of the area was contaminated. Therefore, for the purpose of this report, the floor space figures were not used as a means of estimating contaminated concrete.

Other pertinent observations from the SFIA data base are as follows:

1. $0.02 \%$ of the buildings are in $\mathrm{D} \& \mathrm{D}, 34 \%$ are operating, $11 \%$ are classified as "other", $37 \%$ are shut down, $12 \%$ are abandoned, and $3 \%$ are deactivated.

2. $63 \%$ of the buildings have reinforced concrete construction, $20 \%$ are concrete block/masonry, $25 \%$ are steel frame, $3 \%$ are wood, and $22 \%$ are "others".

\section{BEMR data base}

The BEMR data base contained 3937 records of contaminated DOE buildings. Only 759 of these buildings had detailed information on the estimated percentage of floor contamination. Table 2 lists these 759 buildings. From this data set the following observations were made:

1. Facilities are listed by estimated floor space contaminated (in square feet). Figure 2.1 illustrates the results by percentage, showing Hanford and Y-12 to consume over $50 \%$ of the contaminated area known at the time the data base was compiled. 
2. Types of facilities: $86 \%$ were radiologically contaminated process buildings, $9 \%$ were non-radiologically contaminated buildings, $2 \%$ were research reactors, $1 \%$ were production reactors, $0.66 \%$ were gaseous diffusion plants, and $1 \%$ were not classified.

3. Operation status: $60.74 \%$ were active, $3.95 \%$ were standby, $19.10 \%$ were surplus, $1.19 \%$ were surplus cleanup-approved, and $15.02 \%$ were not classified.

4. Contaminate type: $31.49 \%$ were not classified, $0.66 \%$ were asbestos, $2.37 \%$ were chemically contaminated, $8.04 \%$ contained mixed radiological and hazardous contaminants, $0.13 \%$ contained nuclear contaminants, $56.92 \%$ were radiologically contaminated, and $0.40 \%$ were unknown.

5. Fixed-form contamination: $96.27 \%$ had no fixed contamination, $3 \%$ had $10 \%$ fixed contamination, $0.05 \%$ had $80 \%$ fixed contamination, $0.08 \%$ had $95 \%$ fixed contamination, $0.23 \%$ had $99 \%$ fixed contamination, and $0.26 \%$ had $100 \%$ fixed contamination.

6. Contaminants: $82.61 \%$ not classified (characterized), $1.58 \%$ fission products, $1.58 \%$ asbestos, $1.32 \%$ beta, $1.58 \%{ }^{137} \mathrm{Cs}, 1.58 \%$ lead, $1.58 \%$ plutonium, $1.05 \%{ }^{90} \mathrm{Sr}, 1.18 \%$ uranium series, and the remainder of contaminants contributed less than $1 \%$ : acetone, americium, barium, benzoic acid, beta/gamma, boron, cadmium, ${ }^{14} \mathrm{C}$, chromium, ${ }^{60} \mathrm{Co}$ gamma, iron, lithium hydroxide, mercury, ${ }^{237} \mathrm{~Np},{ }^{63} \mathrm{Ni},{ }^{94} \mathrm{Nb}$, nitric acid, PCBs, radium, and ${ }^{90} \mathrm{Y}$.

7. When the entire record set of 3937 buildings was considered, 647 had light concrete (thickness less than $1 \mathrm{ft}$ ) and 1247 had heavy concrete (more than $1 \mathrm{ft}$ thick).

\section{CROSSWALK data base}

Table B.3 is from the CROSSWALK Technology Needs Assessment data base, which provides pertinent concrete decontamination needs for a variety of DOE sites. This information was used as a basis for the site evaluations presented in Appendix A.

The CROSSWALK data base was queried for sites that need concrete decontamination technology or any technology related to concrete $\mathrm{D} \& \mathrm{D}$ in general. The sites that occurred as having a concrete decontamination technology needs were ANL, BCL, BNL, FEMP, FUSRAP, HANF, INEL ITRI, LLNL, LANL, ORNL, SRS, and WSR. The primary media were labeled as masonry debris, construction debris, or buried material for the majority of the sites in need of technology (Table B.3). In other words, needs for in situ decontamination occurred rarely 


\section{B-4}

in this query. In general, the observations from the query were:

1. Sites evaluated existing technologies to be costly and labor-intensive.

2. It was believed existing technologies do not to minimize worker exposure.

3. Sites desired to reduce secondary waste volume (rubble) from existing technology, since permanent disposal of the material was costly.

4. Remote decontamination methods are needed (not within the scope of this report).

5. Sites desired to try a variety of technologies, e.g., chemical treatment, abrasives, highpressure water, chemical leaching and etching, and scabbling. 
Table B.1. Facility information from the SFIA data base

\begin{tabular}{|c|c|c|c|c|c|}
\hline Site & Facility & $\begin{array}{l}\text { Operational } \\
\text { Status }\end{array}$ & Construction & $\begin{array}{l}\text { Primary or Potential } \\
\text { Contaminants }\end{array}$ & $\begin{array}{c}\text { Floor Space, } \\
\mathrm{ft}^{2}\end{array}$ \\
\hline ANLE & Reactor Zero IX (IN15) & Shut down & Reinforced concrete & U-235, U-238, Pu-239 & 1,200 \\
\hline ANLE & Reactor Zero VI (IN315) & Shut down & Reinforced concrete & U-235, U-238, Pu-239 & 1,200 \\
\hline ANLE & Fast Neutron Generator & Other & Concrete/mason block & $\begin{array}{l}\text { H-3, U-235, U-238, Pu-239, } \\
\text { Am-241, Cf-252, Th-232, } \\
\text { Pu-241, Pu-242, Pu-244 }\end{array}$ & 6,038 \\
\hline ANLE & Engineering Physics/SPO & Other & Concrete/mason block & Unknown & 598 \\
\hline ANLE & Applied Physics and TIS & Other & Reinforced concrete & $\mathrm{U}-235, \mathrm{U}-238$ & 450 \\
\hline ANLE & Reactor Janus ANL (IN202) & Deactivated & Reinforced concrete & Co-60, I-131, Cs-137, U-235 & 10,200 \\
\hline ANLE & Accel CY CR 21M (IN211-C) & Shut down & Reinforced concrete & & 7,048 \\
\hline ANLW & Fuel Manufacturing Facility & Operating & Reinforced concrete & $\begin{array}{l}\mathrm{H}-3, \mathrm{U}-235, \mathrm{U}-238, \mathrm{~Np}-237 \\
\text { Pu-238, Pu-239, Am-241 }\end{array}$ & 6,650 \\
\hline ANLW & Treat Reactor Building & Operating & Steel frame & $\begin{array}{l}\text { Co-60, Sr-90/Y-90, I-126, I- } \\
131, \text { I-133, Cs-134, Cs-137, } \\
\text { U-235, U-238, Pu-238, Pu-239 }\end{array}$ & 16,800 \\
\hline ANLW & Laboratory and office building & Operating & Concrete/mason block & $\begin{array}{l}\text { H-3, Co-60, Sr-90/Y-90, I-131, } \\
\text { I-133, Cs-134, Cs-137, Eu-152, } \\
\text { Eu-154, Eu-155, U-235, U-238, } \\
\text { Np-237, Pu-238, Pu-239, } \\
\text { Am-241 }\end{array}$ & 62,614 \\
\hline ANLW & Sanitary Waste Pump House & Operating & Other & Unknown & 183 \\
\hline ANLW & Fuel cycle facility & Operating & Reinforced concrete & Other & 22,700 \\
\hline ANLW & Reactor building & Operating & Other & $\begin{array}{l}\text { H-3, Co-60, Sr-90/Y-90, I-126, } \\
\text { I-131, I-133, Cs-134, Cs-137, } \\
\text { Eu-152, Eu-154, Eu-155, } \\
\text { Ra-223, Ra-224, U-235, Np-237, } \\
\text { U-238, Pu-238, Pu-239, } \\
\text { Am-241, Am-243, other }\end{array}$ & 9,000 \\
\hline ANLW & Argonne Fast Source Reactor & Standby & Steel frame & $\begin{array}{l}\text { Co-60, Cs-137, U-235, U-238, } \\
\text { Pu-239 }\end{array}$ & 1,600 \\
\hline ANLW & ZPPR vault-workroom equipment room & Operating & Reinforced concrete & $\begin{array}{l}\text { Co-60, Cs-137, U-235, U-238, } \\
\text { Pu-239, Am-241, Am-243 }\end{array}$ & 4,200 \\
\hline ANLW & ZPPR Reactor Cell & Standby & Reinforced concrete & $\begin{array}{l}\text { Co-60, Cs-137, U-235, U-238, } \\
\text { Pu-239, Am-241, Am-243 }\end{array}$ & 3,600 \\
\hline ANLW & Laundry sorting building & Operating & Other & Unknown & 583 \\
\hline ANLW & ZPPR material control building & Operating & Steel frame & $\begin{array}{l}\text { Co-60, U-235, U-238, Pu-239, } \\
\text { Th-232 }\end{array}$ & 4,400 \\
\hline ANLW & Hot fuel examination facility & Operating & Steel frame & Other & 57,704 \\
\hline
\end{tabular}


Table B.1. (continued)

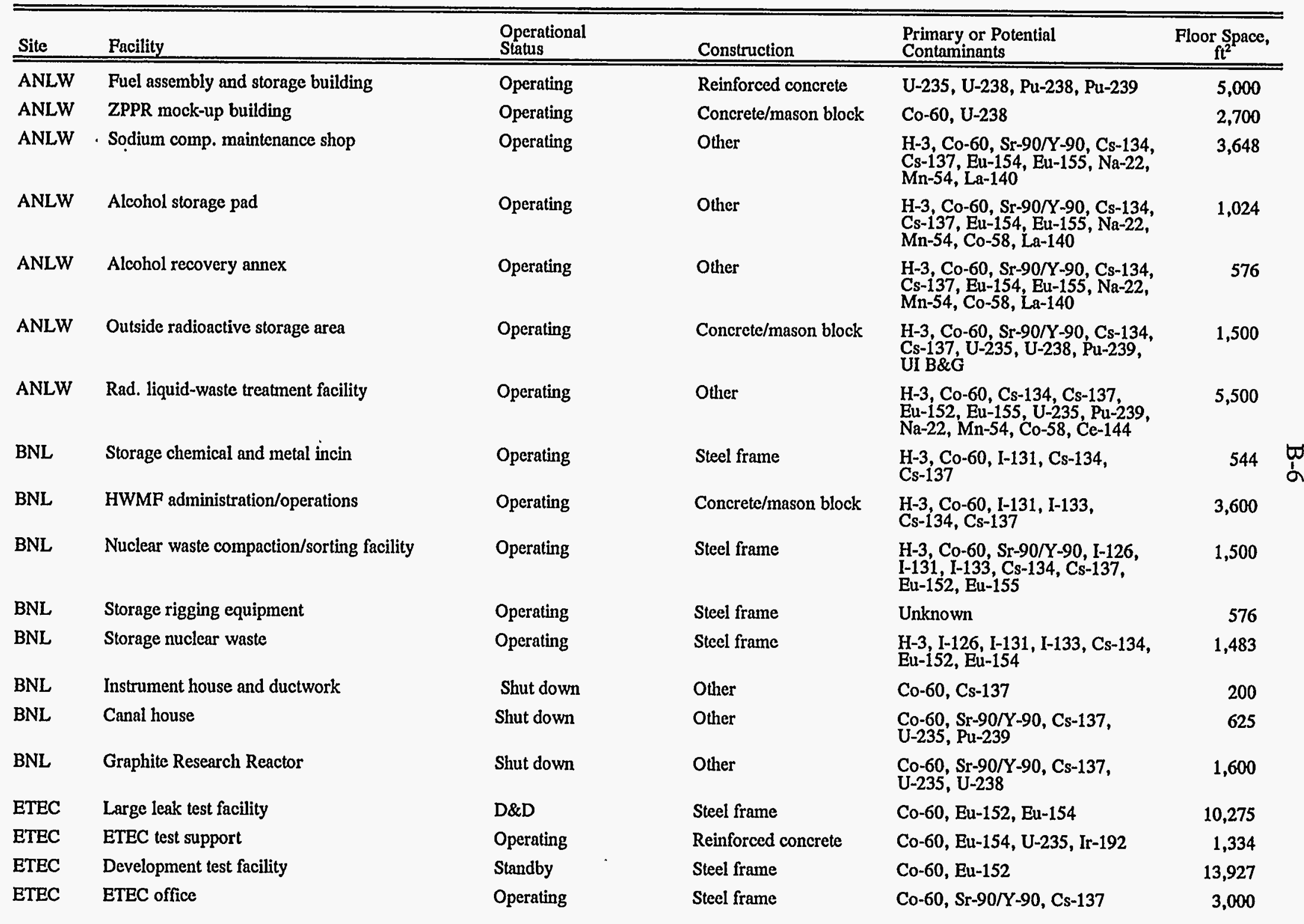


Table B.1. (continued)

\begin{tabular}{|c|c|c|c|c|c|}
\hline Site & Facility & $\begin{array}{l}\text { Operational } \\
\text { Status } \\
\end{array}$ & Construction & $\begin{array}{l}\text { Primary or Potential } \\
\text { Contaminants } \\
\end{array}$ & $\begin{array}{c}\text { Floor Space, } \\
\mathrm{ft}^{2}\end{array}$ \\
\hline ETEC & Radioactive storage & Operating & Steel frame & Co-60, Sr-90/Y-90, Cs-137 & 3,910 \\
\hline ETEC & Drainage sump & Operating & Other & Co- 60, Cs- 137 & 0 \\
\hline ETĖC & Hot laboratory & D\&D & Other & Co-60, Sr-90/Y-90, Cs-137 & 17,799 \\
\hline HANF & Mechanical properties lab & Operating & Steel frame & Activation products & 4,150 \\
\hline HANF & Materials evaluation lab & Operating & Concrete/mason block & $\mathrm{Pu}-238, \mathrm{Pu}-239, \mathrm{Am}-241$ & 1,296 \\
\hline HANP & SP-100 GES test facility & Shut down & Other & $\mathrm{U}-235, \mathrm{U}-238, \mathrm{Pu}-238, \mathrm{Pu}-239$ & 46,700 \\
\hline INEL & Advance reactivity measurement facility & Standby & Concrete/mason block & Co-60, Cs-137, U-235, U-238 & 2,100 \\
\hline INEL & Maintenance shop & Operating & Concrete/mason block & & 5,752 \\
\hline INEL & Warm waste monitor station & Shut down & Other & Co-60, Cs-137 & \\
\hline INEL & Stack gas monitor building & Shut down & Steel frame & Co-60, Cs-137 & 853 \\
\hline INEL & Reactor building & Shut down & Concrete/mason block & $\begin{array}{l}\text { Co-60, Sr-90/Y-90, I-131, I-133, } \\
\text { Cs-134, Cs-137, U-235, U-238, } \\
\text { Pu-238, fission prod. }\end{array}$ & 19,046 \\
\hline INEL & Hot waste storage tank & Shut down & Reinforced concrete & $\begin{array}{l}\text { Co-60, Sr-90/Y-90, I-131, I-133, } \\
\text { Cs-134, Cs-137, U-235, U-238, } \\
\text { fission prod. }\end{array}$ & 0 \\
\hline INEL & Primary water storage tank & Shut down & Steel frame & Co-60, Cs-137 & \\
\hline INEL & Liquid nitrogen storage tank & Shut down & Steel frame & Co-60, Cs-137 & \\
\hline LANL & Press building & Operating & Reinforced concrete & $\mathrm{U}-235$ & 11,245 \\
\hline LANL & Laboratory building & $D \& D$ & Concrete/mason block & & 21,420 \\
\hline LANL & Laboratory building & D\&D & Concrete/mason block & & 4,600 \\
\hline LANL & Filter building & Operating & Concrete/mason block & & 843 \\
\hline LANL & Filter house & Operating & Concrete/mason block & & 1,059 \\
\hline LANL & Lab building & Operating & Reinforced concrete & $\mathrm{H}-3, \mathrm{U}-235, \mathrm{Pu}-239$ & 7,154 \\
\hline LANL & Phase separation pit & Deactivated & Other & $\begin{array}{l}\text { H-3, Sr-90/Y-90, Cs-137, Pu- } \\
239, \mathrm{La}-140\end{array}$ & 2,300 \\
\hline LANL & Air filter building & Deactivated & Reinforced concrete & $\begin{array}{l}\mathrm{H}-3, \mathrm{Sr}-90 / \mathrm{Y}-90, \mathrm{Cs}-137, \mathrm{Pu}- \\
239, \mathrm{La}-40\end{array}$ & 8,709 \\
\hline LANL & Lab meson facility & Operating & Steel frame & & 316,249 \\
\hline
\end{tabular}


Table B.1. (continued)

\begin{tabular}{|c|c|c|c|c|c|}
\hline Site & Facility & $\begin{array}{l}\text { Operational } \\
\text { Status } \\
\end{array}$ & Construction & $\begin{array}{l}\text { Primary or Potential } \\
\text { Contaminants }\end{array}$ & $\begin{array}{c}\text { Floor Space, } \\
\mathrm{ft}^{2} \\
\end{array}$ \\
\hline LANL & Pump shed & Operating & Other & & 315 \\
\hline LANL & WNR target cell \#4 & $\mathrm{D} \& \mathrm{D}$ & Concrete/mason block & & 315 \\
\hline LBL & 071 HILAC & Deactivated & Steel frame & Co-60, U-235 & 56,797 \\
\hline LLNL & Heavy element facility & Operating & Concrete/mason block & $\begin{array}{l}\mathrm{Np}-237, \mathrm{Pu}-238, \mathrm{Pu}-239, \mathrm{Am}- \\
241, \mathrm{Am}-243, \mathrm{Cm}-244, \mathrm{Cm}-246, \\
\mathrm{Pu}-244, \mathrm{U}-232, \mathrm{U}-233, \mathrm{U}-235 \\
\mathrm{U}-238, \mathrm{Pu}-240, \mathrm{Pu}-242\end{array}$ & 35,677 \\
\hline LLNL & Reactor dome & Operating & Reinforced concrete & $\begin{array}{l}\text { Co-60, Sr-90/Y-90, I-133, Cs- } \\
134, \text { Cs-137, U-235, fission from } \\
\text { fuel }\end{array}$ & 5,250 \\
\hline LLNL & Geoscience and Environmental Research Program & Operating & Wood & $\begin{array}{l}\text { Co-60, Sr-90/Y-90, I-126, I-131, } \\
\text { I-133, Cs-134, Cs-137, Eu-152, } \\
\text { Eu-154, Eu-155, Ra-223, U-235, } \\
\text { U-238, Pu-238, Pu-239 }\end{array}$ & 55,629 \\
\hline LLNL & $\mathrm{B} 251$ & Operating & Reinforced concrete & $\begin{array}{l}\text { Np-237, Pu-238, Pu-239, Am- } \\
241, \mathrm{Am}-243, \mathrm{Cm}-244, \mathrm{Cm}-246, \\
\text { Pu-240, Pu-242, Pu-244, U-232, } \\
\text { U-233, U-235, U-238 }\end{array}$ & 35,677 \\
\hline NTS & 16-tunnel & Abandoned & Other & $\begin{array}{l}\text { H-3, Co-60, Sr-90/Y-90, I-131, } \\
\text { I-133, Cs-134, Cs-137, Eu-152, } \\
\text { Eu-154, Eu-155, U-235, Np-237, } \\
\text { U-238, Pu-239, Am-241 }\end{array}$ & $2,850,000$ \\
\hline NTS & E-tunnel (U12E) & Shut down & Other & $\begin{array}{l}\mathrm{H}-3, \mathrm{Co}-60, \mathrm{Sr}-90 / Y-90, \mathrm{I}-131, \\
\mathrm{I}-133, \mathrm{Cs}-134, \mathrm{Cs}-137, \mathrm{Eu}-152 \\
\text { Eu-154, Eu-155, U-235, Np-237, } \\
\text { U-238, Pu-239, Am-241 }\end{array}$ & 69,696 \\
\hline NTS & G-tunnel (U12G) & Shut down & Other & $\begin{array}{l}\mathrm{H}-3, \mathrm{Co}-60, \mathrm{Sr}-90 / Y-90, \mathrm{I}-131, \\
\mathrm{I}-133, \mathrm{Cs}-134, \mathrm{Cs}-137, \mathrm{Eu}-152 \\
\text { Eu-154, Eu-155, U-235, Np-237, } \\
\text { U-238, Pu-239, Am-241 }\end{array}$ & 211,000 \\
\hline NTS & N-tunnel (U12N) & Shut down & Other & $\begin{array}{l}\mathrm{H}-3, \mathrm{Co}-60, \mathrm{Sr}-90 / Y-90, \mathrm{I}-131 \\
\mathrm{I}-133, \mathrm{Cs}-134, \mathrm{Cs}-137, \mathrm{Eu}-152 \\
\text { Eu-154, Eu-155, U-235, Np-237, } \\
\text { U-238, Pu-239, Am-241 }\end{array}$ & 317,000 \\
\hline NTS & K-tunnel, U12K & Abandoned & Other & $\begin{array}{l}\mathrm{H}-3, \mathrm{CO}-60, \mathrm{Sr}-90 / Y-90, \mathrm{I}-131 \\
\mathrm{I}-133, \mathrm{Cs}-134, \mathrm{Cs}-137, \mathrm{Eu}-152 \\
\text { Eu-154, Eu-155, U-235, Np-237, } \\
\text { U-238, Pu-239, Am-241 }\end{array}$ & 5,000 \\
\hline
\end{tabular}


Table B.1. (continued)

\begin{tabular}{|c|c|c|c|c|c|}
\hline Site & Pacility & $\begin{array}{l}\text { Operational } \\
\text { Status } \\
\end{array}$ & Construction & $\begin{array}{l}\text { Primary or Potential } \\
\text { Contaminants }\end{array}$ & $\begin{array}{c}\text { Floor Space, } \\
\mathrm{ft}^{2}\end{array}$ \\
\hline NTS & J-tunnel, U12J & Abandoned & Other & $\begin{array}{l}\mathrm{H}-3, \mathrm{CO}-60, \mathrm{Sr}-90 / Y-90, \mathrm{I}-131 \\
\mathrm{I}-133, \mathrm{Cs}-134, \mathrm{Cs}-137, \mathrm{Eu}-152 \\
\text { Eu-154, Eu-155, U-235, Np-237, } \\
\text { U-238, Pu-239, Am-241 }\end{array}$ & 5,000 \\
\hline NTS & I-tunnel, U12I & Abandoned & Other & $\begin{array}{l}\mathrm{H}-3, \mathrm{Co}-60, \mathrm{Sr}-90 / \mathrm{Y}-90, \mathrm{I}-131 \\
\mathrm{I}-133, \mathrm{Cs}-134, \mathrm{Cs}-137, \mathrm{Eu}-152 \\
\text { Eu-154, Eu-155, U-235, Np-237, } \\
\text { U-238, Pu-239, Am-241 }\end{array}$ & 5,000 \\
\hline NTS & F-tunnel, U12F & Abandoned & Other & $\begin{array}{l}\mathrm{H}-3, \mathrm{Co}-60, \mathrm{Sr}-90 / Y-90, \mathrm{I}-131, \\
\mathrm{I}-133, \mathrm{Cs}-134, \mathrm{Cs}-137, \mathrm{Eu}-152 \\
\mathrm{Eu}-154, \mathrm{Eu}-155, \mathrm{U}-235, \mathrm{~Np}-237, \\
\mathrm{Pu}-238, \mathrm{Pu}-239, \mathrm{Am}-241\end{array}$ & 10,000 \\
\hline NTS & D-tunnel, U12D & Abandoned & Other & $\begin{array}{l}\text { H-3, Co-60, Sr-90/Y-90, I-131, } \\
\text { I-133, Cs-134, Cs-137, Eu-152, } \\
\text { Eu-154, Eu-155, U-235, Np-237, } \\
\text { U-238, Pu-239, Am-241 }\end{array}$ & 10,000 \\
\hline NTS & C-tunnel, U12C & Abandoned & Other & $\begin{array}{l}\mathrm{H}-3, \mathrm{Co}-60, \mathrm{Sr}-90 / Y-90, \mathrm{I}-131 \\
\mathrm{I}-133, \mathrm{Cs}-134, \mathrm{Cs}-137, \mathrm{Eu}-152 \\
\text { Eu-154, Eu-155, U-235, Np-237, } \\
\mathrm{U}-238, \mathrm{Pu}-239, \mathrm{Am}-241\end{array}$ & 10,000 \\
\hline NTS & T-tunnel (U12T) & Shut down & Other & $\begin{array}{l}\text { H-3, Co-60, Sr-90/Y-90, I-131, } \\
\text { I-133, Cs-134, Cs-137, Eu-152, } \\
\text { Eu-154, Eu-155, U-235, Np-237, } \\
\text { U-238, Pu-239, Am-241 }\end{array}$ & 79,200 \\
\hline NTS & U2U cellar & Abandoned & Other & $\begin{array}{l}\mathrm{H}-3, \mathrm{Co}-60, \mathrm{Sr}-90 / \mathrm{Y}-90, \mathrm{I}-131, \\
\mathrm{I}-133, \mathrm{Cs}-134, \mathrm{Cs}-137, \mathrm{Eu}-152 \\
\text { Eu-154, Eu-155, U-235, Np-237, } \\
\text { U-238, Pu-239, Am-241 }\end{array}$ & \\
\hline NTS & U2DC-2 cellar & Abandoned & Other & $\begin{array}{l}\mathrm{H}-3, \mathrm{Co}-60, \mathrm{Sr}-90 / \mathrm{Y}-90, \mathrm{I}-131, \\
\mathrm{I}-133, \mathrm{Cs}-134, \mathrm{Cs}-137, \mathrm{Eu}-152 \\
\text { Eu-154, Eu-155, U-235, Np-237, } \\
\text { U-238, Pu-239, Am-241 }\end{array}$ & \\
\hline NTS & Large airplane structure wreckage front section & Abandoned & Other & $\mathrm{Pu}-238$ & 0 \\
\hline NTS & Large airplane structure wreckage, tail section & Abandoned & Other & $\mathrm{Pu}-238$ & 0 \\
\hline NTS & Radioactive material storage facility & Abandoned & Other & Unknown & 6,300 \\
\hline ORISE & Isolation Barn-SC11 & Abandoned & Wood & Cs-137, Eu-152, Eu-154 & 3,022 \\
\hline ORISE & Isotope Laboratory-SC2 & Abandoned & Concrete/mason block & $\begin{array}{l}\mathrm{H}-3, \mathrm{Co}-60, \mathrm{Sr}-90 / \mathrm{Y}-90, \mathrm{Cs}-137, \\
\text { Eu-152, Eu-154, Eu-155, Am- } \\
241\end{array}$ & 952 \\
\hline
\end{tabular}


Table B.1. (continued)

\begin{tabular}{|c|c|c|c|c|c|}
\hline Site & Facility & $\begin{array}{l}\text { Operational } \\
\text { Status } \\
\end{array}$ & Construction & $\begin{array}{l}\text { Primary or Potential } \\
\text { Contaminants } \\
\end{array}$ & $\begin{array}{c}\text { Floor Space, } \\
\mathrm{ft}^{2}\end{array}$ \\
\hline ORISE & Nutrition barn slab & Abandoned & Reinforced concrete & Sr-90/Y-90, Am-241 & 11,900 \\
\hline ORNL & Coal lab hood & Shut down & Other & $\mathrm{U}-238$ & 20 \\
\hline ORNL & East research service sat shop & Shut down & Concrete/mason block & Unknown & 180 \\
\hline ORNL & Stack & Shut down & Reinforced concrete & Unknown & 140 \\
\hline ORNL & Office building & Operating & Wood & $\begin{array}{l}\text { Cs-137, U-235, U-238, Pu-239, } \\
\text { Th-232, U-236 }\end{array}$ & 12,372 \\
\hline ORNL & High-level radiation analytical lab & Shut down & Concrete/mason block & Sr-90/Y-90, Cs-137, Cm-244 & 3,000 \\
\hline ORNL & Biology & Other & Concrete/mason block & $\begin{array}{l}\text { H-3, } 1-126 \text {, unknown, C-14, } \\
\text { P-32, P-33 }\end{array}$ & 247,000 \\
\hline ORNL & Green house & Shut down & Other & $\mathrm{Pu}-239$ & 338 \\
\hline ORNL & Hot storage garden & Standby & Reinforced concrete & $\begin{array}{l}\text { Co-60, Sr-90/Y-90, Cs-137, } \\
\text { Eu-154, U-235, U-238, Pu-239 }\end{array}$ & 900 \\
\hline ORNL & Storage shed & Shut down & Reinforced concrete & Unknown & 200 \\
\hline ORNL & Source development laboratory & Shut down & Steel frame & Co-60, Sr-90/Y-90, Cs-137 & 2,273 \\
\hline ORNL & Alpha powder facility & Shut down & Steel frame & $\begin{array}{l}\mathrm{I}-131, \mathrm{~Np}-237, \mathrm{U}-238, \mathrm{Pu}-238 \\
\mathrm{Am}-241, \mathrm{Am}-243, \mathrm{Cm}-242 \\
\mathrm{Cm}-244, \mathrm{Pm}-147, \mathrm{FP}^{\prime} \mathrm{s}, \mathrm{Xe}-133\end{array}$ & 17,054 \\
\hline ORNL & Isotope area storage and service & Shut down & Steel frame & Unknown & 1,250 \\
\hline ORNL & Storage cubicle for krypton & Shut down & Reinforced concrete & $\mathrm{Kr}-85$ & 176 \\
\hline ORNL & Isotope technology building (hot cells) & Shut down & Concrete/mason block & $\begin{array}{l}\text { Co-60, Sr-90/Y-90, I-131, Cs- } \\
137, \text { Eu-155, U-235, Np-237, } \\
\text { Pu-239, Am-241, Am-243 }\end{array}$ & 16,000 \\
\hline ORNL & Solid state annex & Operating & Wood & Unknown & 25,860 \\
\hline ORNL & New hydrofracture facility & Other & Concrete/mason block & Sr-90/Y-90, Cs-137 & 4,500 \\
\hline ORNL & Cell off-gas filter house for 3019 & Shut down & Concrete/mason block & Th-232, U-233 & 146 \\
\hline ORNL & Integrated process demonstration & Operating & Other & $\mathrm{U}-238$ & 19,750 \\
\hline ORNL & Cell ventilation filters & Deactivated & Reinforced concrete & $\mathrm{Co}-60, \mathrm{Eu}-151, \mathrm{Ir}-192$ & 445 \\
\hline ORNL & Cell ventilation filter & Other & Reinforced concrete & Unknown & 250 \\
\hline ORNL & Charcoal filter (NOG) ORR & Shut down & Steel frame & Unknown & 127 \\
\hline ORNL & BSR heat exchanger and pump house & Other & Concrete/mason block & Unknown & 667 \\
\hline ORNL & Off-gas filters for ORR & Other & Concrete/mason block & Unknown & 104 \\
\hline ORNL & ORR cooling tower 3 & Other & Steel frame & Unknown & 3,340 \\
\hline
\end{tabular}


Table B.1. (continued)

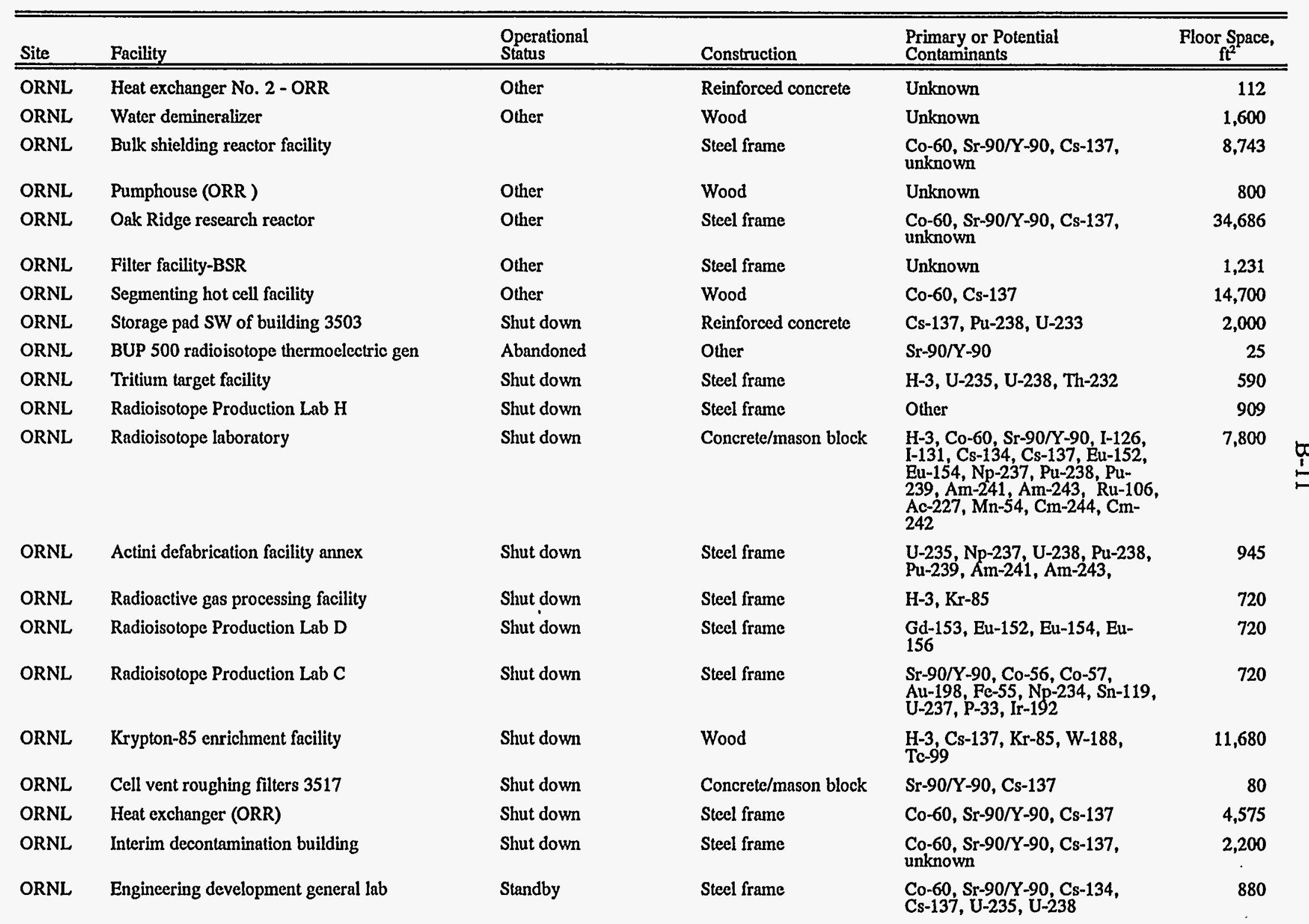


Table B.1. (continued)

\begin{tabular}{|c|c|c|c|c|c|}
\hline Site & Pacility & $\begin{array}{l}\text { Operational } \\
\text { Status } \\
\end{array}$ & Construction & $\begin{array}{l}\text { Primary or Potential } \\
\text { Contaminants } \\
\end{array}$ & $\begin{array}{c}\text { Floor Space, } \\
\mathrm{ft}^{2}\end{array}$ \\
\hline ORNL & Coal conversion facility & Operating & Steel frame & $\begin{array}{l}\text { Co-60, Sr-90/Y-90, Cs-134, } \\
\text { Cs-137, U-235, U-238 }\end{array}$ & 1,392 \\
\hline ORNL & Pilot pits 1 and 2 & Shut down & Concrete/mason block & Sr-90/Y-90, Cs-137 & 1,000 \\
\hline ORNL & Alpha greenhouse facility & Shut down & Concrete/mason block & $\begin{array}{l}\text { Sr-90/Y-90, Cs-137, Np-237, } \\
\text { U-238, Pu-239 }\end{array}$ & 518 \\
\hline ORNL & Sewage digester building & Abandoned & Concrete/mason block & Unknown & 500 \\
\hline ORNL & QA \& I & Operating & Concrete/mason block & Unknown & 10,300 \\
\hline ORNL & Fission product development lab & Shut down & Steel frame & $\begin{array}{l}\mathrm{Co}-60, \mathrm{Sr}-90 / \mathrm{Y}-90, \mathrm{Cs}-137 \\
\mathrm{Eu}-152, \mathrm{Eu}-154, \mathrm{Kr}-85, \mathrm{Cm}-244\end{array}$ & 16,708 \\
\hline ORNL & Cell vent filters for 3517 & Shut down & Steel frame & Sr-90/Y-90, Cs-137 & 140 \\
\hline ORNL & Radioisotope Production Lab E & Other & Steel frame & $\begin{array}{l}\mathrm{Co}-60, \mathrm{Sr}-90 / \mathrm{Y}-90, \mathrm{Cs}-137 \\
\mathrm{U}-235, \mathrm{Am}-241\end{array}$ & 720 \\
\hline PGDP & Storage facility & Abandoned & Other & U-238, TRU & 3,666 \\
\hline PORTS & Mechanical testing building & Abandoned & Steel frame & U-235, U-238, Am-241, Tc & 22,640 \\
\hline RFETS & Building 444 , manufacturing facility & Operating & Concrete/mason block & $\begin{array}{l}\mathrm{Co}-60, \mathrm{Sr}-90 / \mathrm{Y}-90, \mathrm{Cs}-137, \\
\text { U-238, Ir-204 }\end{array}$ & 161,980 \\
\hline RFETS & Building 447 , manufacturing facility & Standby & Concrete/mason block & $\mathrm{U}-238$ & 23,100 \\
\hline RFETS & Building 451 , filter plenum & Operating & Steel frame & U-238 & 3,645 \\
\hline RFETS & Building 455 , filter plenum & Operating & Other & $\mathrm{U}-238$ & 394 \\
\hline RFETS & Building 879 , filter plenum & Operating & Steel fraine & $\mathrm{U}-238$ & 3,680 \\
\hline RFETS & Building 883 , rolling and forming facility & Operating & Concrete/mason block & $\mathrm{Ra}-223, \mathrm{U}-235, \mathrm{U}-238$ & 52,350 \\
\hline RFETS & Building 450 , ventilation supply (filter) plenum & Operating & Steel frame & $\mathrm{U}-238$ & 4,320 \\
\hline SP & KMS fusion facility & Deactivated & Concrete/mason block & $\mathrm{H}-3$ & \\
\hline SNLL & 828 Light Lab & Operating & Wood & U-238, deplet. U & 13,591 \\
\hline SNLL & 844 General Lab & Other & Steel frame & $\begin{array}{l}\mathrm{H}-3, \mathrm{Co}-60, \mathrm{Cs}-137, \mathrm{Pu}-238, \\
\mathrm{Ba}-137\end{array}$ & 4,189 \\
\hline SNLL & 845 General Lab & Other & Steel frame & U-238, deplet. U & 4,227 \\
\hline SNLL & 901 General Lab & Operating & Reinforced concrete & $\mathrm{H}-3$ & 1,854 \\
\hline
\end{tabular}


Table B.1. (continued)

\begin{tabular}{|c|c|c|c|c|c|}
\hline Site & Pacility & $\begin{array}{l}\text { Operational } \\
\text { Status } \\
\end{array}$ & Construction & $\begin{array}{l}\text { Primary or Potential } \\
\text { Contaminants }\end{array}$ & $\begin{array}{c}\text { Floor Space, } \\
\mathrm{ft}^{2}\end{array}$ \\
\hline SRS & Manufacturing building, 232-F & Abandoned & Reinforced concrete & $\mathbf{H}-\mathbf{3}$ & 19,260 \\
\hline SRS & EC process building, $247-7 \mathrm{~F}$ & Other & Steel frame & $\mathrm{U}-235$ & 5,760 \\
\hline SRS & Naval fuels man. building 247-F, (core) & Shut down & Concrete/mason block & $\mathrm{U}-235$ & 34,726 \\
\hline SRS & Metallurgical building, 235-F (PUFF) & Shut down & Reinforced concrete & $\mathrm{Pu}-238$ & 7,015 \\
\hline SRS & Metallurgical building, 235-F (old metal lab) & Shut down & Reinforced concrete & $\mathrm{Pu}-238$ & 435 \\
\hline SRS & Manipulator repair shop, 779-000A & Abandoned & Reinforced concrete & U-238, U-233, U-234 & 5,400 \\
\hline SRS & Beta gamma incinerator & Shut down & Steel frame & Other & 5,500 \\
\hline SRS & Waste evaporator \# 1, 242-F & Shut down & Reinforced concrete & Cs-137, Ru-106 & 720 \\
\hline SRS & Waste evaporator \# 1, 242-H & Operating & Reinforced concrete & Cs-137 & 600 \\
\hline SRS & Concentrator building, 420-D & Operating & Reinforced concrete & Unknown & 9,000 \\
\hline SRS & Rework handling facility, 420-2D & Operating & Reinforced concrete & H-3, unknown & 440 \\
\hline SRS & Moderator handling and storage, $421-2 \mathrm{D}$ & Operating & Reinforced concrete & H-3, unknown & 3,200 \\
\hline SRS & cooling water effluent weir, 107-L & Shut down & Reinforced concrete & Únknown & 1,000 \\
\hline SRS & Reactor building, 105-L & Shut down & Reinforced concrete & $\begin{array}{l}\mathrm{H}-3, \mathrm{Co}-60, \mathrm{Sr}-90 / \mathrm{Y}-90, \mathrm{I}-126, \\
\mathrm{I}-131, \mathrm{I}-133, \mathrm{Cs}-134, \mathrm{Cs}-137, \\
\text { Eu-152, Eu-154, Eu-155, Ra- } \\
223, \mathrm{Ra}-224, \mathrm{U}-235, \mathrm{~Np}-237, \mathrm{U}- \\
\text { 238, Pu-238, Pu-239, Am-241, } \\
\text { Am-243, unknown, fission prod. }\end{array}$ & $1,000,000$ \\
\hline SRS & Sand filter, 105-9L & Shut down & Reinforced concrete & $\begin{array}{l}\mathrm{H}-3, \mathrm{Co}-60, \text { Sr-90/Y-90, I-131, } \\
\text { Cs-134, Cs-137, Eu-155, U-235, } \\
\text { U-238, Pu-238, Pu-239, } \\
\text { unknown, Cs-134 }\end{array}$ & 900 \\
\hline SRS & $\begin{array}{l}\text { Underground contaminated water storage tank, } \\
106-\mathrm{L}\end{array}$ & Shut down & Reinforced concrete & Unknown & $\mathbf{0}$ \\
\hline SRS & Reactor building, 105-P & Shut down & Reinforced concrete & $\begin{array}{l}\mathrm{H}-3, \mathrm{Co}-60, \mathrm{Sr}-90 / \mathrm{Y}-90, \mathrm{I}-126, \\
\mathrm{I}-131, \mathrm{I}-133, \mathrm{Cs}-134, \mathrm{Cs}-137, \\
\text { Eu-152, Eu-154, Eu-155, Ra- } \\
223, \mathrm{Ra}-224, \mathrm{U}-235, \mathrm{~Np}-237, \mathrm{U}- \\
238, \mathrm{Pu}-238, \text { Pu-239, Am-241, } \\
\text { Am-243, unknown, fission prod. }\end{array}$ & $1,000,000$ \\
\hline
\end{tabular}


Table B.1. (continued)

\begin{tabular}{|c|c|c|c|c|c|}
\hline Site & Facility & $\begin{array}{l}\text { Operational } \\
\text { Status } \\
\end{array}$ & Construction & $\begin{array}{l}\text { Primary or Potential } \\
\text { Contaminants } \\
\end{array}$ & Floor Space, \\
\hline SRS & U.G. contaminated water storage tank, 106-P & Shut down & Reinforced concrete & Unknown & 600 \\
\hline SRS & Cooling water effluent weir, 107-p & Shut down & Reinforced concrete & Unknown & 864 \\
\hline SRS & Purge water storage tank, 109-P & Shut down & Reinforced concrete & Co-60, unknown & 120 \\
\hline SRS & Basin deionizer pad, 105-10L & Shut down & Reinforced concrete & $\begin{array}{l}\mathrm{H}-3, \mathrm{Co}-60, \mathrm{Sr}-90 / \mathrm{Y}-90, \mathrm{I}-131 \\
\mathrm{Cs}-134, \mathrm{Cs}-137\end{array}$ & 1,600 \\
\hline SRS & U.G. contaminated water storage tank, 106-R & Shut down & Reinforced concrete & Unknown & 200 \\
\hline SRS & Purge water storage tank, 109-R & Shut down & Reinforced concrete & Unknown & 140 \\
\hline SRS & Receiving tank/105 building sump pumps, 106-C & Shut down & Reinforced concrete & Unknown & 1,350 \\
\hline SRS & Hot shop/storage shed, 717-C & Operating & Reinforced concrete & Unknown & 0 \\
\hline SRS & Cooling water effluent sump, 904-1C & Shut down & Reinforced concrete & Unknown & 375 \\
\hline SRS & Shield cooling water dump tank, 109-L & Shut down & Reinforced concrete & Co-60, unknown & 305 \\
\hline SRS & Cooling water effluent sump, 904-L & Operating & Reinforced concrete & Unknown & \\
\hline SRS & Reactor building, 105-C & Shut down & Reinforced concrete & $\begin{array}{l}\mathrm{H}-3, \mathrm{Co}-60, \mathrm{Sr}-90 / Y-90, \mathrm{I}-126, \\
\mathrm{I}-131, \mathrm{I}-133, \mathrm{Cs}-134, \mathrm{Cs}-137, \\
\text { Eu-152, Eu-154, Eu-155, Ra- } \\
223, \mathrm{Ra}-224, \mathrm{U}-235, \mathrm{~Np}-237, \mathrm{U}- \\
238, \mathrm{Pu}-238, \mathrm{Pu}-239, \mathrm{Am}-241 \text {, } \\
\text { Am-243, unknown, fission prod. }\end{array}$ & 750,000 \\
\hline SRS & Reactor building, 105-R & Shut down & Reinforced concrete & $\begin{array}{l}\mathrm{H}-3, \mathrm{Co}-60, \mathrm{Sr}-90 / \mathrm{Y}-90, \mathrm{I}-126, \\
\mathrm{I}-131, \mathrm{I}-133, \mathrm{Cs}-134, \mathrm{Cs}-137, \\
\text { Eu-152, Eu-154, Eu-155, Ra- } \\
223, \mathrm{Ra}-224, \mathrm{U}-235, \mathrm{~Np}-237, \mathrm{U}- \\
\text { 238, Pu-238, Pu-239, Am-241, } \\
\text { Am-243, unknown, fission prod. }\end{array}$ & 1,$000 ; 000$ \\
\hline SRS & L-Area maintenance shop, 717-G & Shut down & Reinforced concrete & Unknown & 2,400 \\
\hline SRS & Process heat exchanger repair, $690-\mathrm{N}$ & Shut down & Other & $\begin{array}{l}\mathrm{H}-3, \mathrm{Co}-60, \mathrm{Sr}-90 / \mathrm{Y}-90, \mathrm{I}-126, \\
\mathrm{I}-131, \mathrm{I}-133, \mathrm{Cs}-134, \mathrm{Cs}-137, \\
\mathrm{Eu}-152, \mathrm{Eu}-154, \mathrm{Eu}-155, \mathrm{Ra}- \\
223, \\
\mathrm{Ra}-224, \mathrm{U}-235, \mathrm{~Np}-237, \mathrm{U}-238, \\
\mathrm{Pu}-238, \mathrm{Pu}-239, \mathrm{Am}-241, \\
\text { Am-243, unknown, fission prod. }\end{array}$ & 10,500 \\
\hline SRS & $\begin{array}{l}\text { Change house contaminated equipment shop, } \\
707-G\end{array}$ & Shut down & Reinforced concrete & Unknown & 960 \\
\hline SRS & Storage building, 712-G & Shut down & Reinforced concrete & Unknown & 60 \\
\hline SRS & Purge water storage tank, $109-\mathrm{C}$ & Shut down & Reinforced concrete & Unknown & 248 \\
\hline SRS & Slug fabrication facility, $313-\mathrm{M}$ & Shut down & Concrete/mason block & $\mathrm{U}-235, \mathrm{U}-238$ & 75,912 \\
\hline
\end{tabular}


Table B.1. (continued)

\begin{tabular}{|c|c|c|c|c|c|}
\hline Site & Facility & $\begin{array}{l}\text { Operational } \\
\text { Status }\end{array}$ & Construction & $\begin{array}{l}\text { Primary or Potential } \\
\text { Contaminants }\end{array}$ & $\begin{array}{c}\text { Floor Space, } \\
\mathrm{ft}^{2}\end{array}$ \\
\hline SRS & Fuel fabrication facility, 321-M & Operating & Steel frame & $\mathrm{U}-235, \mathrm{~Np}-237, \mathrm{U}-238, \mathrm{Pu}-238$ & 57,672 \\
\hline SRS & Chemical transfer facility, 313-M, CTF & Operating & Steel frame & $\mathrm{U}-238$ & 6,800 \\
\hline SRS & Chemical laboratory, 320-M & Operating & Steel frame & $\mathrm{U}-235, \mathrm{U}-238, \mathrm{Th}$ & 13,752 \\
\hline SRS & Metallurgical laboratory, 322-M & Operating & Steel frame & $\begin{array}{l}\mathrm{H}-3, \mathrm{U}-235, \mathrm{~Np}-237, \mathrm{U}-238, \\
\mathrm{Pu}-238, \mathrm{Am}-241\end{array}$ & 11,411 \\
\hline SRS & Waste filtering building, $340-\mathrm{M}$ & Operating & Steel frame & $\mathrm{U}-235, \mathrm{U}-238$ & 416 \\
\hline SRS & Interim storage facility, $341-1 \mathrm{M}$ & Operating & Steel frame & $\mathrm{U}-235, \mathrm{U}-238$ & 6,000 \\
\hline SRS & Acid scrubber, 313-4M & Deactivated & Reinforced concrete & U-235, U-238 & 512 \\
\hline $\mathrm{Y}-12$ & Testing & Other & Reinforced concrete & $\begin{array}{l}\mathrm{H}-3, \mathrm{Co}-60, \mathrm{Sr}-90 / \mathrm{Y}-90, \mathrm{Cs}-137, \\
\mathrm{U}-235, \mathrm{U}-238, \mathrm{Pu}-238, \mathrm{Pu}-239 \\
\mathrm{Am}-241\end{array}$ & 23,500 \\
\hline ZZOTH & GTF brine pond and others & Abandoned & Other & $\mathrm{Ra}-226$ & 0 \\
\hline
\end{tabular}


Table B.2. Facility Information from the BEMR data base

\begin{tabular}{|c|c|c|c|c|c|c|}
\hline $\begin{array}{l}\text { Site } \\
\text { Code } \\
\end{array}$ & $\begin{array}{l}\text { Bldg. } \\
\text { Number } \\
\end{array}$ & $\begin{array}{l}\text { Site } \\
\text { Type }\end{array}$ & Operating Status & $\begin{array}{c}\text { Contaminant } \\
\text { Type }\end{array}$ & $\begin{array}{l}\text { Approx. Area of } \\
\text { Contamination, } \mathrm{ft}^{3} \\
\end{array}$ & Contaminant Name \\
\hline ANLE & 200 & 3 & active & $\mathbf{R}$ & $3,595,850$ & \\
\hline ANLE & 203 & 3 & active & & $2,934,830$ & asbestos \\
\hline ANLE & 203 & 3 & active & & $2,934,830$ & radium \\
\hline ANLE & 212 & 3 & surplus, cleanup approved & $\mathbf{R}$ & $3,034,900$ & \\
\hline ANLE & 301 & 3 & surplus, cleanup approved & $\mathbf{R}$ & $1,527,500$ & \\
\hline ANLE & 315 & 8 & active & $\mathbf{R}$ & 537,520 & \\
\hline ANLE & 335 & 8 & active & $\mathbf{R}$ & 14,582 & \\
\hline ANLE & 4 & 3 & active & $\mathbf{R}$ & 27,900 & \\
\hline ANLE & 5 & 3 & active & $\mathbf{R}$ & 37,530 & \\
\hline ANLE & 6 & 3 & active & $\mathbf{R}$ & 19,000 & \\
\hline ANLE & 24 & 3 & active & $\mathbf{R}$ & 6,075 & \\
\hline ANLE & 25 & 3 & active & $\mathbf{R}$ & 6,400 & \\
\hline ANLE & 26 & 3 & active & $\mathbf{R}$ & 2,300 & \\
\hline ANLE & 27 & 3 & active & $\mathbf{R}$ & 420 & \\
\hline ANLE & 28 & 3 & active & $\mathbf{R}$ & 2,800 & \\
\hline ANLE & 33 & 3 & active & $\mathbf{R}$ & 2,280 & \\
\hline ANLE & 40 & 3 & active & $\mathbf{R}$ & 49,290 & \\
\hline ANLE & 202 & 3 & active & $\mathbf{R}$ & $1,954,782$ & \\
\hline ANLE & 301 & 3 & active & $\mathbf{R}$ & $1,527,500$ & \\
\hline ANLE & 306 & 3 & active & $\mathbf{R}$ & 413,600 & \\
\hline ANLE & 314 & 3 & active & $\mathbf{R}$ & 177,020 & \\
\hline ANLE & 330 & 3 & active & $\mathbf{R}$ & $2,053,760$ & \\
\hline ANLE & 331 & 3 & active & $\mathbf{R}$ & 40,064 & \\
\hline ANLE & $33 \mathrm{~T}$ & 3 & active & $\mathbf{R}$ & 250 & \\
\hline ANLE & 350 & 3 & active & $\mathbf{R}$ & $1,026,144$ & \\
\hline ANLE & 381 & 3 & active & $\mathbf{R}$ & 385,000 & \\
\hline ANLE & 481 & 3 & active & $\mathbf{R}$ & 4,710 & \\
\hline ANLE & 809 & 3 & active & $\mathbf{R}$ & 5,427 & \\
\hline ANLE & 810 & 3 & active & $\mathbf{R}$ & 4,634 & \\
\hline ANLE & 813 & 3 & active & $\mathbf{R}$ & 6,301 & \\
\hline ANLE & 815 & 3 & active & $\mathbf{R}$ & 9,700 & \\
\hline ANLE & 821 & 3 & active & $\mathbf{R}$ & 5,231 & \\
\hline ANLE & 822 & 3 & active & $\mathbf{R}$ & 4,100 & \\
\hline ANLE & 823 & 3 & active & $\mathbf{R}$ & 4,100 & \\
\hline ANLE & 826 & 3 & active & $\mathbf{R}$ & 800 & \\
\hline ANLE & 827 & 3 & active & $\mathbf{R}$ & 3,200 & \\
\hline ANLE & $827 \mathrm{~T} 3$ & 3 & active & $\mathbf{R}$ & 288 & \\
\hline ANLE & 828 & 3 & active & $\mathbf{R}$ & 240 & \\
\hline
\end{tabular}


B-17

Table B.2. (continued)

\begin{tabular}{|c|c|c|c|c|c|}
\hline $\begin{array}{l}\text { Site } \\
\text { Code }\end{array}$ & $\begin{array}{l}\text { Bldg. } \\
\text { Number }\end{array}$ & $\begin{array}{l}\text { Site } \\
\text { Type }\end{array}$ & Operating Status & $\underset{\text { Type }}{\text { Contaminant }}$ & $\begin{array}{l}\text { Approx. Area of } \\
\text { Contamination, } \mathrm{ft}^{3} \text { Contaminant Name }\end{array}$ \\
\hline ANLE & 829 & 3 & active & $\mathbf{R}$ & 3,032 \\
\hline ANLW & 752 & 3 & active & $\mathbf{R}$ & 250,455 \\
\hline BNL & 89 & 3 & active & $\mathbf{R}$ & 465,000 \\
\hline BNL & 90 & 3 & active & $\mathbf{R}$ & 475,000 \\
\hline BNL & . 91 & 3 & active & $\mathbf{R}$ & 470,000 \\
\hline $\mathrm{BNL}$ & 100 & 3 & active & $\mathbf{R}$ & 680,000 \\
\hline BNL & 196 & 3 & active & $\mathbf{R}$ & 135,000 \\
\hline $\mathrm{BNL}$ & 208 & 3 & active & $\mathbf{R}$ & 600,000 \\
\hline BNL & 444 & 3 & active & $\mathbf{R}$ & 37,500 \\
\hline BNL & 446 & 3 & active & $\mathbf{R}$ & 32,000 \\
\hline BNL & 491 & 8 & active & $\mathbf{R}$ & 115,000 \\
\hline BNL & 494 & 3 & active & $\mathbf{R}$ & 407,500 \\
\hline BNL & 529 & 3 & active & $\mathbf{R}$ & 270,000 \\
\hline BNL & 650 & 3 & active & $\mathbf{R}$ & $1,071,000$ \\
\hline BNL & 701 & 8 & active & $\mathbf{R}$ & 347,000 \\
\hline BNL & 704 & 3 & active & $\mathbf{R}$ & 186,000 \\
\hline BNL & 709 & 3 & active & $\mathbf{R}$ & 200,000 \\
\hline BNL & 725 & 3 & active & $\mathbf{R}$ & $7,260,000$ \\
\hline BNL & 750 & 8 & active & $\mathbf{R}$ & 948,000 \\
\hline BNL & 811 & 3 & active & $\mathbf{R}$ & 72,000 \\
\hline BNL & 901 & 3 & active & $\mathbf{R}$ & 955,000 \\
\hline BNL & 909 & 3 & active & $\mathbf{R}$ & $1,175,000$ \\
\hline BNL & 913 & 3 & active & $\mathrm{R}$ & 51,200 \\
\hline BNL & 925 & 3 & active & $\mathbf{R}$ & 50,000 \\
\hline BNL & 930 & 3 & active & $\mathrm{R}$ & $4,060,000$ \\
\hline BNL & 931 & 3 & active & $\mathbf{R}$ & 150,000 \\
\hline ETEC & 49 & 3 & active & $\mathbf{R}$ & 80,000 \\
\hline ETEC & 59 & 3 & standby & $\mathbf{R}$ & 51,375 \\
\hline ETEC & 0 & 3 & active & $\mathbf{R}$ & 42,343 \\
\hline ETEC & 21 & 3 & active & $\mathbf{R}$ & 90,000 \\
\hline ETEC & 22 & 3 & active & $\mathbf{R}$ & 117,300 \\
\hline ETEC & 24 & 3 & active & $\mathbf{R}$ & 208,905 \\
\hline ETEC & 34 & 3 & active & $\mathbf{R}$ & 6,200 \\
\hline ETEC & 44 & 3 & active & $\mathbf{R}$ & 8,000 \\
\hline ETEC & 75 & 3 & active & $\mathbf{R}$ & 86,400 \\
\hline FUSRAP & 1 & 3 & standby & $\mathbf{R}$ & $12,000,000$ \\
\hline FUSRAP & 1 & 3 & active & $\mathrm{R}$ & 312,500 \\
\hline FUSRAP & 294 & 3 & standby & $\mathbf{R}$ & $1,549,400$ \\
\hline FUSRAP & 297 & 3 & active & $\mathbf{R}$ & 47,880 \\
\hline
\end{tabular}


B-18

Table B.2. (continued)

\begin{tabular}{|c|c|c|c|c|c|c|}
\hline $\begin{array}{l}\text { Site } \\
\text { Code } \\
\end{array}$ & $\begin{array}{l}\text { Bldg. } \\
\text { Number }\end{array}$ & $\begin{array}{c}\text { Site } \\
\text { Type } \\
\end{array}$ & Operating Status & $\begin{array}{c}\text { Contaminant } \\
\text { Type }^{b}\end{array}$ & $\begin{array}{l}\text { Approx. Area of } \\
\text { Contamination, } \mathrm{ft}^{3}\end{array}$ & Contaminant Name \\
\hline FUSRAP & 403 & 3 & active & $\mathrm{R}$ & 140,000 & \\
\hline FUSRAP & 1 & 3 & active & $\mathbf{R}$ & 750,000 & \\
\hline GJPO & 33 & 3 & active & $\mathbf{R}$ & 692,400 & \\
\hline GJPO & 34 & 3 & active & $\mathbf{R}$ & 88,400 & \\
\hline GJPO & 35 & 3 & active & $\mathbf{R}$ & 286,300 & \\
\hline HANF & $233 S$ & 3 & surplus & $\mathbf{M}$ & 310,000 & plutonium \\
\hline HANF & $233 S$ & 3 & surplus & $\mathbf{M}$ & 310,000 & neptunium-237 \\
\hline HANF & $233 S$ & 3 & surplus & $\mathbf{M}$ & 310,000 & nitric acid \\
\hline HANF & $233 S$ & 3 & surplus & $\mathbf{M}$ & 310,000 & asbestos \\
\hline HANF & $232 Z$ & 3 & surplus & $\mathbf{R}$ & 259,000 & plutoninm \\
\hline HANF & $232 Z$ & 3 & surplus & $\mathbf{R}$ & 259,000 & lead \\
\hline HANF & $232 Z$ & 3 & surplus & $\mathrm{R}$ & 259,000 & gamma \\
\hline HANF & $232 Z$ & 3 & surplus & $\mathbf{R}$ & 259,000 & asbestos \\
\hline HANF & $232 Z$ & 3 & surplus & $\mathbf{R}$ & 259,000 & americium \\
\hline HANF & $105 \mathrm{KW}$ & 1 & surplus & $\mathrm{R}$ & $8,221,400$ & lead \\
\hline HANF & $105 \mathrm{~N}$ & 1 & surplus & $\mathbf{R}$ & $8,780,100$ & lead \\
\hline HANF & $105 C$ & 1 & surplus & $\mathbf{R}$ & $7,164,500$ & lead \\
\hline HANF & $105 B$ & 1 & surplus & $\mathbf{R}$ & $5,357,100$ & cadmium \\
\hline HANF & $105 B$ & 1 & surplus & $\mathbf{R}$ & $5,357,100$ & lead \\
\hline HANF & $105 \mathrm{H}$ & 1 & surplus & $\mathbf{R}$ & $7,464,000$ & cadminum \\
\hline HANF & $105 \mathrm{H}$ & 1 & surplus & $\mathbf{R}$ & $7,464,000$ & lead \\
\hline HANF & 105DR & 1 & surplus & $\mathbf{R}$ & $5,830,000$ & lead \\
\hline HANF & $105 \mathrm{D}$ & 1 & surplus & $\mathbf{R}$ & $5,554,200$ & lead \\
\hline HANF & $216 Z 9 B$ & 3 & surplus & $\mathbf{R}$ & 100,000 & plutonium \\
\hline HANF & $242 \mathrm{~T}$ & 3 & surplus & $M$ & 135,650 & \\
\hline HANF & $242 S$ & 3 & surphus & $\mathbf{M}$ & 417,000 & \\
\hline HANF & $105 \mathrm{~F}$ & 1 & surplus & $\mathbf{R}$ & $5,460,000$ & lead \\
\hline HANF & $105 \mathrm{~F}$ & 1 & surplus & $\mathbf{R}$ & $5,460,000$ & cadmium \\
\hline HANF & $224 B$ & 3 & surplus & M & $1,615,000$ & fission products \\
\hline HANF & $224 B$ & 3 & surplus & $\mathbf{M}$ & $1,615,000$ & plutonium \\
\hline HANF & $212 N$ & 3 & surplus & $\mathbf{R}$ & 59,790 & beta \\
\hline HANF & $212 \mathrm{~N}$ & 3 & surplus & $\mathbf{R}$ & 59,790 & plutonium \\
\hline HANF & $212 \mathrm{P}$ & 3 & surplus & $\mathbf{M}$ & 59,790 & beta \\
\hline HANF & $212 R$ & 3 & surplus & $\mathbf{R}$ & 59,790 & beta \\
\hline HANF & $225 B$ & 3 & active & $\mathbf{M}$ & 204,630 & fission products \\
\hline HANF & $241 S \times 401$ & 3 & surplus & $\mathrm{R}$ & 86,500 & beta \\
\hline HANF & $241 S X 402$ & 3 & surplus & $\mathbf{R}$ & 9,700 & \\
\hline HANF & $202 S$ & 2 & surphus & $\mathbf{R}$ & $11,994,800$ & beta \\
\hline HANF & $202 S$ & 2 & surplus & $\mathbf{R}$ & $11,994,800$ & plutonium \\
\hline
\end{tabular}


B-19

Table B.2. (continued)

\begin{tabular}{|c|c|c|c|c|c|c|}
\hline $\begin{array}{l}\text { Site } \\
\text { Code } \\
\end{array}$ & $\begin{array}{l}\text { Bldg. } \\
\text { Number }\end{array}$ & $\begin{array}{l}\text { Site } \\
\text { Type } \\
\end{array}$ & Operating Status & $\begin{array}{c}\text { Contaminant } \\
\text { Type } \\
\end{array}$ & $\begin{array}{l}\text { Approx. Area of } \\
\text { Contamination, } \mathrm{ft}^{3} \\
\end{array}$ & Contaminant Name \\
\hline HANF & $221 U$ & 2 & surplus & $\mathbf{M}$ & $6,262,500$ & beta \\
\hline HANF & $241 C 801$ & 3 & surphus & $\mathbf{R}$ & 83,000 & beta \\
\hline HANF & $276 U$ & 3 & surplus & $\mathbf{M}$ & 132,500 & beta \\
\hline HANF & $205 A$ & 3 & surplus & $\mathbf{M}$ & 9,600 & fission products \\
\hline HANF & $241 \mathrm{~A} 431$ & 3 & surplus & $\mathbf{R}$ & 34,600 & \\
\hline HANF & $242 B$ & 3 & surplus & $\mathbf{R}$ & 189,910 & fission products \\
\hline HANF & $117 \mathrm{~N}$ & 3 & surplus & $\mathbf{R}$ & 429,000 & \\
\hline HANF & $107 \mathrm{~N}$ & 3 & surplus & $\mathbf{R}$ & 567,675 & \\
\hline HANF & $109 \mathrm{~N}$ & 3 & surplus & $\mathbf{R}$ & $5,383,200$ & \\
\hline HANF & $1314 \mathrm{~N}$ & 3 & surplus & $\mathbf{R}$ & 90,000 & \\
\hline HANF & $221 B$ & 2 & active & $\mathbf{M}$ & $6,262,500$ & asbestos \\
\hline HANF & $221 B$ & 2 & active & $\mathbf{M}$ & $6,262,500$ & fission products \\
\hline HANF & $222 S$ & 3 & active & $\mathbf{R}$ & 598,805 & fission products \\
\hline HANF & $244 \mathrm{AR}$ & 2 & standby & $\mathbf{R}$ & 246,510 & fission products \\
\hline HANF & 204AR & 3 & active & $\mathbf{M}$ & 125,000 & fission products \\
\hline HANF & $242 A$ & 2 & active & $\mathbf{M}$ & 552,354 & fission products \\
\hline HANF & $202 A$ & 2 & standby & $\mathbf{M}$ & $15,111,200$ & fission products \\
\hline HANF & 224UA & 3 & surplus & $\mathbf{R}$ & 500,000 & uranium \\
\hline HANF & $224 \mathrm{~T}$ & 3 & active & $\mathbf{R}$ & $1,615,000$ & plutonium \\
\hline HANF & $224 T$ & 3 & active & $\mathbf{R}$ & $1,615,000$ & fission products \\
\hline HANF & $221 \mathrm{~T}$ & 2 & active & $\mathbf{M}$ & $8,793,990$ & fission products \\
\hline HANF & $234-5 Z$ & 3 & active & $\mathbf{M}$ & $17,360,000$ & plutonium \\
\hline HANF & . $234-5 Z$ & 3 & active & $\mathbf{M}$ & $17,360,000$ & americium \\
\hline HANF & $231 Z$ & 3 & active & $\mathbf{M}$ & $2,307,060$ & fission products \\
\hline HANF & $231 Z$ & 3 & active & M & $2,307,060$ & plutonium \\
\hline HANF & $303 \mathrm{M}$ & 3 & standby & $\mathbf{R}$ & 209,500 & uranium \\
\hline HANF & 313 & 3 & active & $\mathbf{R}$ & 393,365 & uranium \\
\hline HANF & 333 & 3 & active & & $1,320,000$. & uranium \\
\hline HANF & 292B & 3 & active & $\mathbf{R}$ & 3,360 & \\
\hline HANF & $108 \mathrm{~F}$ & 3 & surplus & $\mathbf{R}$ & $3,108,400$ & \\
\hline HANF & $115 \mathrm{KE}$ & 3 & surplus & $\mathbf{R}$ & 820,000 & asbestos \\
\hline HANF & $115 \mathrm{KW}$ & 3 & & $\mathbf{R}$ & 820,000 & asbestos \\
\hline HANF & $1706 \mathrm{KE}$ & 3 & active & A & 224,000 & asbestos \\
\hline HANF & $2904 S A$ & 3 & surplus & $\mathbf{N}$ & 6,400 & \\
\hline HANF & 321 & 3 & active & $M$ & 274,390 & asbestos \\
\hline HANF & 308 & 3 & surplus & $\mathbf{R}$ & $4,621,500$ & \\
\hline HANF & $209 \mathrm{E}$ & 3 & active & & 293,172 & \\
\hline HANF & $2718 \mathrm{E}$ & 3 & surplus & & 166,400 & \\
\hline HANF & $291 S$ & 3 & surplus & $\mathbf{R}$ & 669,000 & fission products \\
\hline
\end{tabular}


B-20

Table B.2. (continued)

\begin{tabular}{|c|c|c|c|c|c|c|}
\hline $\begin{array}{l}\text { Site } \\
\text { Code } \\
\end{array}$ & $\begin{array}{l}\text { Bldg. } \\
\text { Number }\end{array}$ & $\begin{array}{l}\text { Site } \\
\text { Type } \\
\end{array}$ & Operating Status & $\begin{array}{c}\text { Contaminant } \\
\text { Type }\end{array}$ & $\begin{array}{l}\text { Approx. Area of } \\
\text { Contamination, } \mathrm{ft}^{3} \\
\end{array}$ & Contaminant Name \\
\hline HANF & $291 S$ & 3 & surplus & $\mathbf{R}$ & 669,000 & beta \\
\hline HANF & $291 S$ & 3 & surplus & $\mathbf{R}$ & 669,000 & beta/gamma \\
\hline HANF & $291 S$ & 3 & surplus & $\mathbf{R}$ & 669,000 & asbestos \\
\hline HANF & 291SA & 3 & surplus & $\mathbf{R}$ & 669,000 & \\
\hline HANF & $292 S$ & 3 & surplus & & 25,000 & \\
\hline HANF & $105 \mathrm{NA}$ & 3 & active & & 19,200 & \\
\hline HANF & $1322 N$ & 3 & active & & 67,600 & \\
\hline HANF & 1322NA & 3 & active & & 20,000 & \\
\hline HANF & $1322 \mathrm{NB}$ & 3 & active & & 32,100 & \\
\hline HANF & $216 A$ & 3 & active & & 960 & \\
\hline HANF & 221BA & 3 & active & & 640 & \\
\hline HANF & 221BB & 3 & active & & 7,150 & \\
\hline HANF & 221BE & 3 & active & & 1,220 & \\
\hline HANF & 221BF & 3 & active & & 28,800 & \\
\hline HANF & $241 \mathrm{~A} 271$ & 3 & active & $\mathbf{R}$ & 5,550 & \\
\hline HANF & $241 \mathrm{~A} 401$ & 3 & active & $\mathbf{R}$ & 10,000 & \\
\hline HANF & 241A701 & 3 & active & $\mathbf{R}$ & 9,200 & \\
\hline HANF & 241AN273 & 3 & active & $\mathbf{R}$ & 2,560 & \\
\hline HANF & 241AY801 & 3 & active & & 4,000 & \\
\hline HANF & 241AZ801 & 3 & active & & 3,920 & \\
\hline HANF & 241BY254 & 3 & active & & 7,400 & \\
\hline HANF & 241BY302 & 3 & active & & 10,280 & \\
\hline HANF & $244 A$ & 3 & active & & 600 & \\
\hline HANF & 244BX & 3 & active & & 3,600 & \\
\hline HANF & 254BY & 3 & active & & 7,400 & \\
\hline HANF & $271 A$ & 3 & active & & 14,400 & \\
\hline HANF & $271 \mathrm{AB}$ & 3 & active & & 499,200 & \\
\hline HANF & 271AN & 3 & active & & 6,400 & \\
\hline HANF & 271AW & 3 & active & & 3,200 & \\
\hline HANF & 271CR & 3 & active & & 6,705 & \\
\hline HANF & 273AW & 3 & active & & 2,560 & \\
\hline HANF & $291 B$ & 3 & active & & 1,650 & \\
\hline HANF & 291BA & 3 & active & & 980 & \\
\hline HANF & 291BB & 3 & active & & 1,440 & \\
\hline HANF & 291BD & 3 & active & & 5,460 & \\
\hline HANF & 291BF & 3 & active & & 2,250 & \\
\hline HANF & 291BH & 3 & active & & 480 & \\
\hline HANF & $295 \mathrm{AD}$ & 3 & active & & 14,400 & \\
\hline HANF & $2712 B$ & 3 & active & & 640 & \\
\hline
\end{tabular}


B-21

Table B.2. (continued)

\begin{tabular}{|c|c|c|c|c|c|c|}
\hline $\begin{array}{l}\text { Site } \\
\text { Code } \\
\end{array}$ & $\begin{array}{l}\text { Bldg. } \\
\text { Number }\end{array}$ & $\begin{array}{l}\text { Site } \\
\text { Type } \\
\end{array}$ & Operating Status & $\begin{array}{c}\text { Contaminant } \\
\text { Type }\end{array}$ & $\begin{array}{l}\text { Approx. Area of } \\
\text { Contamination, } \mathrm{ft}^{3}\end{array}$ & Contaminant Name \\
\hline HANF & $2715 E$ & 3 & active & & 95,200 & \\
\hline HANF & $2716 B$ & 3 & active & & 2,160 & \\
\hline HANF & $2719 \mathrm{E}$ & 3 & active & & 82,600 & \\
\hline HANF & $2724 A$ & 3 & active & & 640 & \\
\hline HANF & $2724 A Z$ & 3 & active & & 640 & \\
\hline HANF & 2724B & 3 & active & & 640 & \\
\hline HANF & 2724BY & 3 & active & & 640 & \\
\hline HANF & $2724 C$ & 3 & active & & 640 & \\
\hline HANF & $2724 \mathrm{CA}$ & 3 & active & & 640 & \\
\hline HANF & $241 S \times 271$ & 3 & active & . & 1,800 & \\
\hline HANF & $241 S \times 701$ & 3 & active & & 5,330 & \\
\hline HANF & $242 \mathrm{~T} 601$ & 3 & active & & 6,720 & \\
\hline HANF & $242 \mathrm{~TB}$ & 3 & surplus & & 1,920 & \\
\hline HANF & $242 Z$ & 3 & surplus & $\mathbf{R}$ & 105,000 & americium-241 \\
\hline HANF & $244 \$ 271$ & 3 & active & & 1,920 & \\
\hline HANF & 2402WA & 3 & active & $\mathbf{M}$ & 360,000 & \\
\hline HANF & $2402 W B$ & 3 & active & $\mathbf{M}$ & 360,000 & \\
\hline HANF & $2402 W C$ & 3 & active & & 360,000 & \\
\hline HANF & $2402 \mathrm{WD}$ & 3 & active & $\mathbf{M}$ & 360,000 & \\
\hline HANF & $2402 W E$ & 3 & active & $\mathbf{M}$ & 360,000 & \\
\hline HANF & $2402 W F$ & 3 & active & $\mathbf{M}$ & 360,000 & \\
\hline HANF & 2402WG & 3 & active & $\mathbf{M}$ & 320,000 & \\
\hline HANF & $2402 W H$ & 3 & active & $\mathbf{M}$ & 320,000 & \\
\hline HANF & $2402 \mathrm{WI}$ & 3 & active & $\mathbf{M}$ & 320,000 & \\
\hline HANF & $2402 \mathrm{WJ}$ & 3 & active & $\mathbf{M}$ & 320,000 & \\
\hline HANF & $2402 W K$ & 3 & active & $\mathbf{M}$ & 320,000 & \\
\hline HANF & $2402 W L$ & 3 & active & $\mathbf{M}$ & 320,000 & \\
\hline HANF & 2403WA & 3 & active & $\mathbf{M}$ & $2,720,000$ & \\
\hline HANF & $2713 W B$ & 3 & active & & 307,500 & \\
\hline HANF & $2724 S X$ & 3 & active & & 640 & \\
\hline HANF & $2724 S Y$ & 3 & active & & 640 & \\
\hline HANF & $2724 \mathrm{~T}$ & 3 & active & & 640 & \\
\hline HANF & $2724 \mathrm{TXB}$ & 3 & active & & 640 & \\
\hline HANF & $2724 U$ & 3 & active & & 640 & \\
\hline HANF & $2724 W$ & 3 & active & & $1,172,560$ & \\
\hline HANF & 2727WA & 3 & active & & 243,000 & \\
\hline HANF & $303 \mathrm{~K}$ & 3 & active & & 64,800 & \\
\hline HANF & 304 & 3 & active & & 148,500 & \\
\hline HANF & $305 \mathrm{~B}$ & 3 & active & $M$ & 229,400 & \\
\hline
\end{tabular}


B-22

Table B.2. (continued)

\begin{tabular}{|c|c|c|c|c|c|}
\hline $\begin{array}{l}\text { Site } \\
\text { Code } \\
\end{array}$ & $\begin{array}{l}\text { Bldg. } \\
\text { Number }\end{array}$ & $\begin{array}{c}\text { Site } \\
\text { Type } \\
\end{array}$ & Operating Status & $\begin{array}{c}\text { Contaminant } \\
\text { Type } \\
\end{array}$ & $\begin{array}{l}\text { Approx. Area of } \\
\text { Contamination, } \mathrm{ft}^{3} \text { Contaminant Name }\end{array}$ \\
\hline HANF & $306 W$ & 3 & active & $\mathbf{R}$ & $1,826,550$ \\
\hline HANF & 309 & 3 & active & $\mathbf{R}$ & 233,540 \\
\hline HANF & 318 & 3 & active & $\mathbf{R}$ & $2,776,270$ \\
\hline HANF & 323 & 3 & active & & 41,500 \\
\hline HANF & 324 & 3 & active & & $9,153,810$ \\
\hline HANF & 325 & 3 & active & & $8,645,520$ \\
\hline HANF & 326 & 3 & active & & $1,893,030$ \\
\hline HANF & 327 & 3 & active & & $2,423,250$ \\
\hline HANF & 329 & 3 & active & & 788,400 \\
\hline HANF & 331 & 3 & active & & $3,517,200$ \\
\hline HANF & 377 & 3 & active & & 424,000 \\
\hline HANF & 3708 & 3 & active & & 265,782 \\
\hline HANF & $3718 \mathrm{~A}$ & 3 & active & & 6,400 \\
\hline HANF & 3720 & 3 & active & & $1,451,500$ \\
\hline HANF & 3730 & 3 & active & & 240,042 \\
\hline HANF & 3745 & 3 & active & & 154,560 \\
\hline HANF & $3745 \mathrm{~A}$ & 3 & active & & 84,282 \\
\hline HANF & $3746 A$ & 3 & active & & 51,000 \\
\hline HANF & 405 & 8 & active & & $8,610,300$ \\
\hline HANF & 427 & 3 & active & & $10,843,300$ \\
\hline HANF & 437 & 3 & active & & $4,797,810$ \\
\hline HANF & $4713 \mathrm{C}$ & 3 & active & & 402,000 \\
\hline HANF & $4713 \mathrm{D}$ & 3 & active & & 315,450 \\
\hline HANF & $6652 \mathrm{H}$ & 3 & active & & 76,020 \\
\hline HANF & $6652 \mathrm{~J}$ & 3 & active & & 7,794 \\
\hline HANF & 66520 & 3 & active & & 120,000 \\
\hline HANF & $189 D$ & 3 & surplus & & 674,124 \\
\hline HANF & 242ZA & 3 & active & & 14,400 \\
\hline HANF & $225 \mathrm{BD}$ & 3 & active & $\mathbf{R}$ & 6,000 \\
\hline HANF & $1706 \mathrm{KEL}$ & 3 & active & & 27,000 \\
\hline HANF & 1706KER & 3 & active & & 57,775 \\
\hline HANF & 320 & 3 & active & $\mathbf{M}$ & 628,740 \\
\hline HANF & $105 \mathrm{CA}$ & 3 & standby & & 169,000 \\
\hline HANF & $215 \mathrm{C}$ & 3 & surplus & & 20,525 \\
\hline HANF & $236 Z$ & 2 & active & & $1,838,700$ \\
\hline HANF & $2403 W B$ & 3 & active & & $2,720,000$ \\
\hline HANF & $2403 W C$ & 3 & active & & $2,720,000$ \\
\hline HANF & $2403 W D$ & 3 & active & & $4,400,000$ \\
\hline HANF & $241 Z$ & 3 & active & & 23,400 \\
\hline
\end{tabular}


B-23

Table B.2. (continued)

\begin{tabular}{|c|c|c|c|c|c|c|}
\hline $\begin{array}{l}\text { Site } \\
\text { Code }\end{array}$ & $\begin{array}{l}\text { Bldg. } \\
\text { Number }\end{array}$ & $\begin{array}{l}\text { Site } \\
\text { Type }\end{array}$ & Operating Status & $\begin{array}{c}\text { Contaminant } \\
\text { Type }\end{array}$ & $\begin{array}{l}\text { Approx. Area of } \\
\text { Contamination, } \mathrm{ft}^{3}\end{array}$ & Contaminant Name \\
\hline HANF & $293 S$ & 3 & surphis & $\bar{R}$ & 136,100 & beta \\
\hline HANF & $293 S$ & 3 & surplus & $\mathbf{R}$ & 136,100 & piutonium \\
\hline HANF & $2711 s$ & 3 & active & $\mathbf{R}$ & 6,400 & \\
\hline HANF & $2718 S$ & 3 & active & $\mathbf{R}$ & 14,400 & \\
\hline HANF & $2736 Z$ & 3 & active & $\mathbf{R}$ & 370,500 & \\
\hline HANF & 2736ZB & 3 & active & $\mathbf{R}$ & $1,368,000$ & \\
\hline HANF & $276 \mathrm{C}$ & 3 & active & $\mathbf{R}$ & 111,200 & \\
\hline HANF & $291 \mathrm{AR}$ & 3 & active & $\mathbf{R}$ & 69,200 & \\
\hline HANF & $291 U$ & 3 & active & $\mathbf{R}$ & 33,000 & \\
\hline HANP & $292 \mathrm{~T}$ & 3 & & $\mathbf{R}$ & 9,190 & \\
\hline HANF & 607 & 3 & active & R & 95,000 & \\
\hline HANF & $105 \mathrm{KE}$ & 1 & surplus & $\mathbf{R}$ & $8,221,400$ & \\
\hline INEL & CPP-640 & 2 & active & M & 16,300 & \\
\hline INEL & AEF-601 & 8 & surplus, cleanup approved & $\mathrm{R}$ & 344,000 & mercury \\
\hline INEL & AEF-601 & 8 & surplus, cleanup approved & $\mathbf{R}$ & 344,000 & lead \\
\hline INEL & AEF-601 & 8 & surplus, cleanup approved & $\mathbf{R}$ & 344,000 & $\begin{array}{l}\text { PCB (general } \\
\text { classification) }\end{array}$ \\
\hline INEL & AEF-601 & 8 & surplus, cleanup approved & $\mathbf{R}$ & 344,000 & boron \\
\hline INEL & AEF-601 & 8 & surplus, cleanup approved & $\mathbf{R}$ & 344,000 & asbestos \\
\hline INEL & AEF-601 & 8 & surplus, cleanup approved & $\mathbf{R}$ & 344,000 & cesium-137 \\
\hline INEL & AEF-601 & 8 & surplus, cleanup approved & $\mathbf{R}$ & 344,000 & cobalt- 60 \\
\hline INEL & ARA-II-606 & 3 & surplus & $\mathbf{R}$ & 3,085 & cesium-137 \\
\hline INEL & ARA-II-613 & 3 & surplus & $\mathbf{R}$ & 1,280 & beta/gamma \\
\hline INEL & ARA-II-615 & 3 & surplus & $\mathbf{R}$ & 836 & beta/gamma \\
\hline INEL & ARA-608 & 8 & surplus & $\mathbf{R}$ & 4,977 & \\
\hline INEL & ARA-607 & 3 & surplus & $\mathbf{R}$ & 435,400 & \\
\hline INEL & ARA-630 & 3 & surplus & $\mathbf{R}$ & 213,300 & \\
\hline INEL & ARA-621 & 3 & surplus & $\mathbf{R}$ & 3,880 & \\
\hline INEL & ARA-622 & 3 & surplus & $\mathrm{R}$ & 96,700 & \\
\hline INEL & ARA-610 & 3 & surplus & $\mathbf{R}$ & 1,051 & \\
\hline INEL & ARA-611 & 3 & surplus & $\mathbf{R}$ & 557 & \\
\hline INEL & TAN-616 & 3 & active & $\mathbf{M}$ & 295,800 & \\
\hline INEL & TRA-603 & 8 & surplus & $\mathbf{M}$ & 45,184 & fission products \\
\hline INEL & TRA-604 & 3 & active & $\mathbf{R}$ & 41,744 & \\
\hline INEL & TRA-642 & 8 & surplus & $\mathbf{M}$ & 47,762 & \\
\hline INEL & TRA-643 & 3 & surplus & $\mathbf{M}$ & 11,151 & \\
\hline INEL & TRA-635 & 3 & active & & 22,046 & \\
\hline INEL & CFA-669 & 3 & surplus & $\mathbf{M}$ & 4,871 & lead \\
\hline INEL & CFA-669 & 3 & surplus & $\mathbf{M}$ & 4,871 & cobalt -60 \\
\hline
\end{tabular}


B-24

Table B.2. (continued)

\begin{tabular}{|c|c|c|c|c|c|c|}
\hline $\begin{array}{l}\text { Site } \\
\text { Code } \\
\end{array}$ & $\begin{array}{l}\text { Bldg. } \\
\text { Number }\end{array}$ & $\begin{array}{l}\text { Site } \\
\text { Type }\end{array}$ & Operating Status & $\begin{array}{c}\text { Contaminant } \\
\text { Type } \\
\end{array}$ & $\begin{array}{l}\text { Approx. Area of } \\
\text { Contamination, } \mathrm{ft}^{3}\end{array}$ & Contaminant Name \\
\hline INEL & CFA-669 & 3 & surplus & $\mathbf{M}$ & 4,871 & niobium-94 \\
\hline INEL & CFA-669 & 3 & surplus & $\mathbf{M}$ & 4,871 & methylene chloride \\
\hline INEL & CFA-669 & 3 & surplus & M & 4,871 & chromium \\
\hline INEL & CFA-669 & 3 & surplus & $\mathbf{M}$ & 4,871 & mercury \\
\hline INEL & CFA-669 & 3 & surplus & $\mathbf{M}$ & 4,871 & asbestos \\
\hline INEL & CFA-669 & 3 & surphus & $\mathbf{M}$ & 4,871 & cesium-137 \\
\hline INEL & CFA-669 & 3 & surplus & M & 4,871 & barium \\
\hline INEL & CFA-669 & 3 & surplus & $\mathbf{M}$ & 4,871 & acetone \\
\hline INEL & CFA-669 & 3 & surplus & M & 4,871 & cadmium \\
\hline INEL & CFA-669 & 3 & surplus & M & 4,871 & benzoic acid \\
\hline INEL & TAN-607 & 3 & surplus & $\mathbf{R}$ & $1,507,010$ & \\
\hline INEL & TRA-669 & 3 & & $\mathrm{R}$ & 22,980 & \\
\hline INEL & TRA-654 & 3 & active & $\mathbf{R}$ & 2,040 & \\
\hline INEL & TRA-647 & 3 & active & $\mathbf{R}$ & 11,793 & \\
\hline INEL & PBF-613 & 3 & active & $\mathbf{R}$ & 10,364 & \\
\hline INEL & TAN-650 & 8 & active & $\mathbf{R}$ & 34,666 & \\
\hline INEL & WMF-610 & 3 & active & $\mathbf{R}$ & 11,591 & \\
\hline INEL & TAN-645 & 3 & active & $\mathbf{R}$ & 8,146 & \\
\hline INEL & TAN-646 & 3 & active & $\mathbf{R}$ & 16,870 & \\
\hline INEL & TAN-604 & 3 & active & $\mathbf{R}$ & 12,170 & \\
\hline INEL & TAN-630 & 3 & surplus & $\mathbf{R}$ & 111,770 & \\
\hline INEL & PBF-620 & 8 & active & $\mathbf{R}$ & 18,902 & \\
\hline INEL & PBF-609 & 3 & active & & 14,706 & \\
\hline INEL & TRA-660 & 3 & active & $\mathbf{R}$ & 2,400 & \\
\hline INEL & ARA-613 & 3 & standby & & 1,280 & \\
\hline INEL & IF-603 & 3 & active & $\mathbf{R}$ & 99,161 & \\
\hline INEL & ARA-601 & 3 & surplus & $\mathrm{R}$ & 294 & \\
\hline INEL & ARA-612 & 3 & surplus & $\mathrm{R}$ & 240 & \\
\hline INEL & ARA-615 & 3 & surplus & $\mathrm{R}$ & 836 & \\
\hline INEL & ARA-631 & 3 & surplus & $\mathbf{R}$ & 19,200 & \\
\hline INEL & B16-603 & 3 & active & $\mathbf{R}$ & 853 & \\
\hline INEL & CPP-1615 & 3 & active & $\mathbf{R}$ & 80 & \\
\hline INEL & CPP-1617 & 3 & active & $\mathrm{R}$ & 800 & \\
\hline INEL & CPP-1618 & 3 & active & $\mathbf{R}$ & 2,000 & \\
\hline INEL & CPP-601 & 3 & active & $\mathbf{R}$ & 72,246 & beta/gamma \\
\hline INEL & CPP-602 & 3 & active & $\mathbf{R}$ & 47,628 & \\
\hline INEL & CPP-603 & 3 & active & $\mathbf{R}$ & 33,564 & \\
\hline INEL & CPP-604 & 3 & active & $\mathrm{R}$ & 19,055 & \\
\hline INEL & CPP-607 & 3 & active & $\mathbf{R}$ & 2,944 & \\
\hline
\end{tabular}


B-25

Table B.2. (continued)

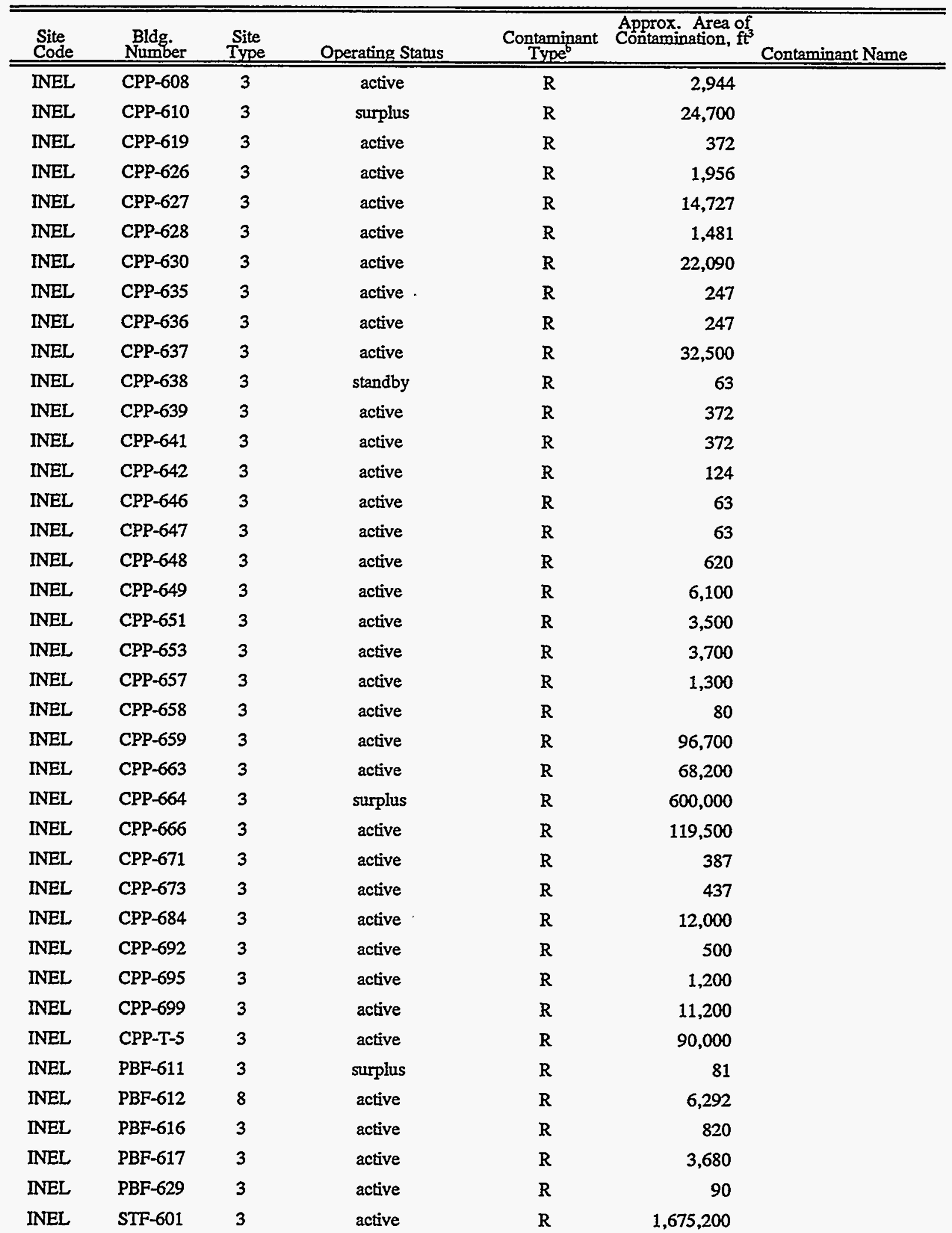


B-26

Table B.2. (continued)

\begin{tabular}{|c|c|c|c|c|c|c|}
\hline $\begin{array}{l}\text { Site } \\
\text { Code }\end{array}$ & $\begin{array}{c}\text { Bldg. } \\
\text { Number }\end{array}$ & $\begin{array}{l}\text { Site } \\
\text { Type }\end{array}$ & Operating Status & $\begin{array}{c}\text { Contaminant } \\
\text { Type }\end{array}$ & $\begin{array}{l}\text { Approx. Area of } \\
\text { Contamination, } \mathrm{ft}^{3}\end{array}$ & Contaminant Name \\
\hline INEL & STF-605 & 3 & standby & $\mathbf{R}$ & 10,800 & \\
\hline INEL & STF-610 & 3 & standby & $\mathbf{R}$ & 97,500 & \\
\hline INEL & STF-611 & 3 & active & $\mathbf{R}$ & 13,500 & \\
\hline INEL & TAN-624 & 3 & active & $\mathbf{R}$ & 3,036 & \\
\hline INEL & TAN-628 & 3 & active & $\mathbf{R}$ & 19,549 & \\
\hline INEL & TAN-640 & 3 & active & $\mathbf{R}$ & 3,345 & \\
\hline INEL & TAN-643 & 3 & surplus & $\mathbf{R}$ & 64 & \\
\hline INEL & TAN-656 & 3 & surplus & $\mathbf{R}$ & 72,000 & \\
\hline INEL & TAN-659 & 3 & surphus & $\mathbf{R}$ & 128 & \\
\hline INEL & TAN-681 & 3 & active & $\mathbf{R}$ & 12,619 & \\
\hline INEL & TAN-682 & 3 & active & $\mathbf{R}$ & 20,064 & \\
\hline INEL & TAN-692 & 3 & active & $\mathbf{R}$ & 900 & \\
\hline INEL & TAN-694 & 3 & active & $\mathbf{R}$ & 597 & \\
\hline INEL & TRA-613A & 3 & active & $\mathbf{R}$ & 210 & \\
\hline INEL & TRA-613B & 3 & active & $\mathbf{R}$ & 210 & \\
\hline INEL & TRA-632 & 3 & active & $\mathbf{R}$ & 17,037 & \\
\hline INEL & TRA-648 & 3 & active & $\mathbf{R}$ & 146,775 & \\
\hline INEL & TRA-666 & 3 & active & $\mathbf{R}$ & 2,400 & \\
\hline INEL & TRA-666A & 3 & active & $\mathbf{R}$ & 1,920 & \\
\hline INEL & WMF-601 & 3 & active & $\mathbf{R}$ & 3,280 & \\
\hline INEL & WMF-612 & 3 & active & $\mathbf{R}$ & 88,500 & \\
\hline ITRI & 9252 & 3 & active & $\mathbf{R}$ & 68,000 & \\
\hline $\mathrm{K}-25$ & $\mathrm{~K}-1301$ & 3 & surplus & & 983,100 & uranium \\
\hline $\mathrm{K}-25$ & $\mathrm{~K}-1302$ & 3 & surplus & & 325,600 & uranium \\
\hline $\mathrm{K}-25$ & $\mathrm{~K}-1008-\mathrm{F}$ & 3 & & & 307,000 & \\
\hline $\mathrm{K}-25$ & 1517 & 3 & active & $\mathrm{R}$ & 20,000 & \\
\hline $\mathrm{KCP}$ & 58 & 3 & & $\mathrm{R}$ & 219,100 & \\
\hline LANL & TA-33-86 & 3 & active & $\mathbf{R}$ & 210,000 & \\
\hline LANL & 1-Feb & 8 & active & $\mathbf{R}$ & 106,540 & \\
\hline LANL & 29-Mar & 3 & active & $\mathbf{R}$ & $1,671,477$ & \\
\hline LANL & 3-Aug & 3 & active & $\mathbf{R}$ & 15,050 & \\
\hline LANL & $18-0026$ & 3 & active & $\mathrm{R}$ & 1,620 & \\
\hline LANL & $18-0129$ & 3 & active & $\mathbf{R}$ & 64,600 & \\
\hline LANL & 21-0003 & 3 & active & $\mathrm{R}$ & 856,800 & \\
\hline LANL & 21-0004 & 3 & active & $\mathrm{R}$ & 356,040 & \\
\hline LANL & $21-0146$ & 3 & active & $\mathbf{R}$ & 42,150 & \\
\hline LANL & 21-0324 & 3 & active & $\mathrm{R}$ & 52,950 & \\
\hline LANL & $22-0001$ & 3 & active & $\mathbf{R}$ & 190,000 & \\
\hline LANL & $50-0001$ & 3 & active & $\mathbf{R}$ & 999,750 & \\
\hline
\end{tabular}


B-27

Table B.2. (continued)

\begin{tabular}{|c|c|c|c|c|c|c|}
\hline $\begin{array}{l}\text { Site } \\
\text { Code } \\
\end{array}$ & $\begin{array}{l}\text { Bldg. } \\
\text { Number }\end{array}$ & $\begin{array}{l}\text { Site } \\
\text { Type } \\
\end{array}$ & Operating Status & $\begin{array}{c}\text { Contaminant } \\
\text { Type }^{b}\end{array}$ & $\begin{array}{l}\text { Approx. Area of } \\
\text { Contamination, } \mathrm{ft}^{3}\end{array}$ & Contaminant Name \\
\hline LANL & $52-0001$ & 3 & active & $\mathbf{R}$ & 836,520 & \\
\hline LANL & $53-0007$ & 3 & active & $\mathbf{R}$ & 291,020 & \\
\hline LANL & $53-0364$ & 3 & active & $\mathbf{R}$ & 16,000 & \\
\hline LANL & $54-0002$ & 3 & active & $\mathbf{R}$ & 16,200 & \\
\hline LBL & $71 / 71 \mathrm{~B}$ & 3 & active & $\mathbf{R}$ & 63,859 & \\
\hline LBL & 88 & 3 & active & $\mathrm{U}$ & 50,713 & \\
\hline LBL & $51 / 51 \mathrm{~A}, \mathrm{~B}$ & 3 & active & $\mathrm{U}$ & 156,411 & \\
\hline LLNL & 292 & 3 & standby & $\mathbf{R}$ & 483,350 & \\
\hline LLNL & 281 & 8 & standby & $\mathbf{R}$ & 144,000 & \\
\hline LLNL & 212 & 3 & standby & $\mathrm{R}$ & $2,526,400$ & \\
\hline LLNL & 251 & 3 & active & $\mathbf{R}$ & 71,354 & \\
\hline LLNL & $321 \mathrm{ABC}$ & 3 & active & $\mathbf{R}$ & 147,983 & \\
\hline LLNL & 331 & 3 & active & $\mathbf{R}$ & 28,777 & \\
\hline LLNL & 332 & 3 & active & $\mathbf{R}$ & 90,189 & \\
\hline MND & SD & 3 & active & & 182,200 & \\
\hline MND & SM & 3 & active & & $2,170,000$ & \\
\hline MND & 21 & 3 & active & & 406,900 & \\
\hline MND & 301 & 3 & active & & 100,000 & \\
\hline NTS & 202685 & 3 & active & $\mathbf{R}$ & 3,380 & \\
\hline NTS & 301839 & 3 & active & $\mathbf{R}$ & $4,390,100$ & \\
\hline NTS & 408154 & 3 & active & $\mathbf{R}$ & 452,470 & \\
\hline ORNL & 3001 & 1 & surplus & $\mathbf{R}$ & 543,090 & uranium oxide \\
\hline ORNL & 3001 & 1 & surplus & $\mathbf{R}$ & 543,090 & uranium oxyfluoride \\
\hline ORNL & 3001 & 1 & surplus & $\mathbf{R}$ & 543,090 & plutonium-239 \\
\hline ORNL & 3001 & 1 & surplus & $\mathbf{R}$ & 543,090 & iron-55 \\
\hline ORNL & 3001 & 1 & surplus & $\mathbf{R}$ & 543,090 & carbon-14 \\
\hline ORNL & 3001 & 1 & surplus & $\mathbf{R}$ & 543,090 & cobalt -60 \\
\hline ORNL & 3001 & 1 & surplus & $\mathbf{R}$ & 543,090 & cesium-137 \\
\hline ORNL & $\begin{array}{l}\text { SITE } \\
7852\end{array}$ & 3 & surplus & & 12,300 & strontium-90 \\
\hline ORNL & $\begin{array}{l}\text { SITE } \\
7852\end{array}$ & 3 & surplus & & 12,300 & cesium-137 \\
\hline ORNL & $\begin{array}{l}\text { SITE } \\
7852\end{array}$ & 3 & surplus & & 12,300 & cobalt-60 \\
\hline ORNL & 3505 & 2 & surplus & & 393,000 & strontium-90 \\
\hline ORNL & 3505 & 2 & surplus & & 393,000 & americium-241 \\
\hline ORNL & 3505 & 2 & surplus & & 393,000 & plutonium \\
\hline ORNL & 3505 & 2 & surpius & & 393,000 & cesium-137 \\
\hline ORNL & 7503 & 8 & surplus & & 152,964 & yttrium-90 \\
\hline ORNL & 7503 & 8 & surplus & & 152,964 & uranium \\
\hline
\end{tabular}


B-28

Table B.2. (continued)

\begin{tabular}{|c|c|c|c|c|c|c|}
\hline $\begin{array}{l}\text { Site } \\
\text { Code } \\
\end{array}$ & $\begin{array}{l}\text { Bldg. } \\
\text { Number }\end{array}$ & $\begin{array}{l}\text { Site } \\
\text { Type } \\
\end{array}$ & Operating Status & $\begin{array}{c}\text { Contaminant } \\
\text { Type }\end{array}$ & $\begin{array}{l}\text { Approx. Area of } \\
\text { Contamination, } \mathrm{ft}^{3} \\
\end{array}$ & Contaminant Name \\
\hline ORNL & 7503 & 8 & surplus & & 152,964 & strontium-90 \\
\hline ORNL & 7503 & 8 & surplus & & 152,964 & plutonium \\
\hline ORNL & 7503 & 8 & surplus & & 152,964 & barium-137m \\
\hline ORNL & 7503 & 8 & surplus & & 152,964 & cesium-137 \\
\hline ORNL & 3506 & 2 & surplus & & 107,500 & cesium-137 \\
\hline ORNL & 3506 & 2 & surplus & & 107,500 & strontium-90 \\
\hline ORNL & 3042 & 8 & surphus & $\mathbf{R}$ & 381,546 & strontium-90 \\
\hline ORNL & 3042 & 8 & surphis & $\mathbf{R}$ & 381,546 & cesium-137 \\
\hline ORNL & 3042 & 8 & surplus & $\mathbf{R}$ & 381,546 & cobalt- 60 \\
\hline ORNL & 3005 & 8 & surplus & & 22,736 & nickel-63 \\
\hline ORNL & 3005 & 8 & surplus & . & 22,736 & iron-55 \\
\hline ORNL & 3005 & 8 & surplus & & 22,736 & cobalt -60 \\
\hline ORNL & 3517 & 2 & surplus & $\mathbf{R}$ & $8,084,800$ & cesium-137 \\
\hline ORNL & 3517 & 2 & surplus & $\mathbf{R}$ & $8,084,800$ & strontium-90 \\
\hline ORNL & 7500 & 8 & surplus & & $1,057,320$ & cesium-137 \\
\hline ORNL & 7500 & 8 & surplus & & $1,057,320$ & strontium-90 \\
\hline ORNL & 3515 & 2 & surplus & & 60,000 & cesium-137 \\
\hline ORNL & 3515 & 2 & surphus & & 60,000 & strontium-90 \\
\hline ORNL & 4507 & 2 & surplus & & 369,764 & \\
\hline ORNL & 1505 & 3 & & & 97,925 & - \\
\hline ORNL & 2000 & 3 & & ' & 45,360 & \\
\hline ORNL & $2011 A$ & 3 & & & 243,768 & \\
\hline ORNL & 2026 & 3 & & & $1,251,000$ & \\
\hline ORNL & 2523 & 3 & & & 90,406 & \\
\hline ORNL & 2531 & 3 & & & 66,984 & \\
\hline ORNL & 2532 & 3 & & & 16,200 & \\
\hline ORNL & 2537 & 3 & & & 7,410 & \\
\hline ORNL & 3002 & 3 & & & 86,712 & \\
\hline ORNL & 3003 & 3 & & & 62,730 & \\
\hline ORNL & 3010 & 8 & & & 43,715 & \\
\hline ORNL & 3012 & 3 & & & 44,612 & \\
\hline ORNL & $3019 B$ & 3 & & & $\quad 189,350$ & \\
\hline ORNL & $3026 C$ & 3 & & & 595,680 & \\
\hline ORNL & $3026 \mathrm{D}$ & 3 & & & 975,502 & \\
\hline ORNL & 3027 & 3 & & & 42,284 & \\
\hline ORNL & 3028 & 3 & & & 528,674 & \\
\hline ORNL & 3029 & 3 & & & 56,825 & \\
\hline ORNL & 3030 & 3 & & & 7,200 & \\
\hline ORNL & 3031 & 3 & & & 7,200 & \\
\hline
\end{tabular}


B-29

Table B.2. (continued)

\begin{tabular}{|c|c|c|c|c|c|}
\hline $\begin{array}{l}\text { Site } \\
\text { Code } \\
\end{array}$ & $\begin{array}{c}\text { Bldg. } \\
\text { Number } \\
\end{array}$ & $\begin{array}{r}\text { Site } \\
\text { Type } \\
\end{array}$ & Operating Status & $\begin{array}{c}\text { Contaminant } \\
\text { Type }\end{array}$ & $\begin{array}{l}\text { Approx. Area of } \\
\text { Contamination, } \mathrm{ft}^{3} \text { Contaminant Name }\end{array}$ \\
\hline ORNL & 3032 & 3 & & & 7,200 \\
\hline ORNL & 3033 & 3 & & & 7,200 \\
\hline ORNL & $3033 A$ & 3 & & & 75,600 \\
\hline ORNL & 3038 & 3 & & & 429,000 \\
\hline ORNL & 3044 & 3 & . & & 157,664 \\
\hline ORNL & 3047 & 3 & & & 768,900 \\
\hline ORNL & 3074 & .3 & & & 94,770 \\
\hline ORNL & 3085 & 3 & & & 5,600 \\
\hline ORNL & 3093 & 3 & . & & 8,800 \\
\hline ORNL & 3095 & 3 & & & 420,480 \\
\hline ORNL & 3100 & 3 & & & 14,772 \\
\hline ORNL & 3110 & 3 & & & 22,250 \\
\hline ORNL & 3118 & 3 & & & 61,812 \\
\hline ORNL & 3119 & 3 & & & 21,600 \\
\hline ORNL & 3121 & 3 & & & 14,016 \\
\hline ORNL & 3503 & 3 & & & 809,235 \\
\hline ORNL & 3504 & 3 & & & 124,372 \\
\hline ORNL & 3508 & 3 & & & 128,754 \\
\hline ORNL & 3518 & 3 & & & 54,600 \\
\hline ORNL & 3525 & 3 & & & $1,598,280$ \\
\hline ORNL & 3541 & 3 & & & 8,200 \\
\hline ORNL & 3544 & 3 & & & 90,784 \\
\hline ORNL & 3550 & 3 & & & 383,532 \\
\hline ORNL & 3592 & 3 & & $\mathbf{R}$ & 77,700 \\
\hline ORNL & 4501 & 3 & & & $1,549,303$ \\
\hline ORNL & 4505 & 3 & & & $1,176,675$ \\
\hline ORNL & 5500 & 3 & & & 62,391 \\
\hline ORNL & 5505 & 3 & & $\mathbf{M}$ & 23,248 \\
\hline ORNL & 7567 & 3 & & $\mathbf{M}$ & 2,400 \\
\hline ORNL & 7601 & 3 & & & 29,778 \\
\hline ORNL & 7602 & 3 & & & 14,208 \\
\hline ORNL & 7604 & 3 & & & 132,600 \\
\hline ORNL & 7025 & 3 & & $\mathbf{R}$ & 15,300 \\
\hline ORNL & 7819 & 3 & & & 220,000 \\
\hline ORNL & 7826 & 3 & & & 222,300 \\
\hline ORNL & 7830 & 3 & & & 69,300 \\
\hline ORNL & 7831 & 3 & & & 345,529 \\
\hline ORNL & 7834 & 3 & & & 149,872 \\
\hline ORNL & 7860 & 2 & & & 53,625 \\
\hline
\end{tabular}


B-30

Table B.2. (continued)

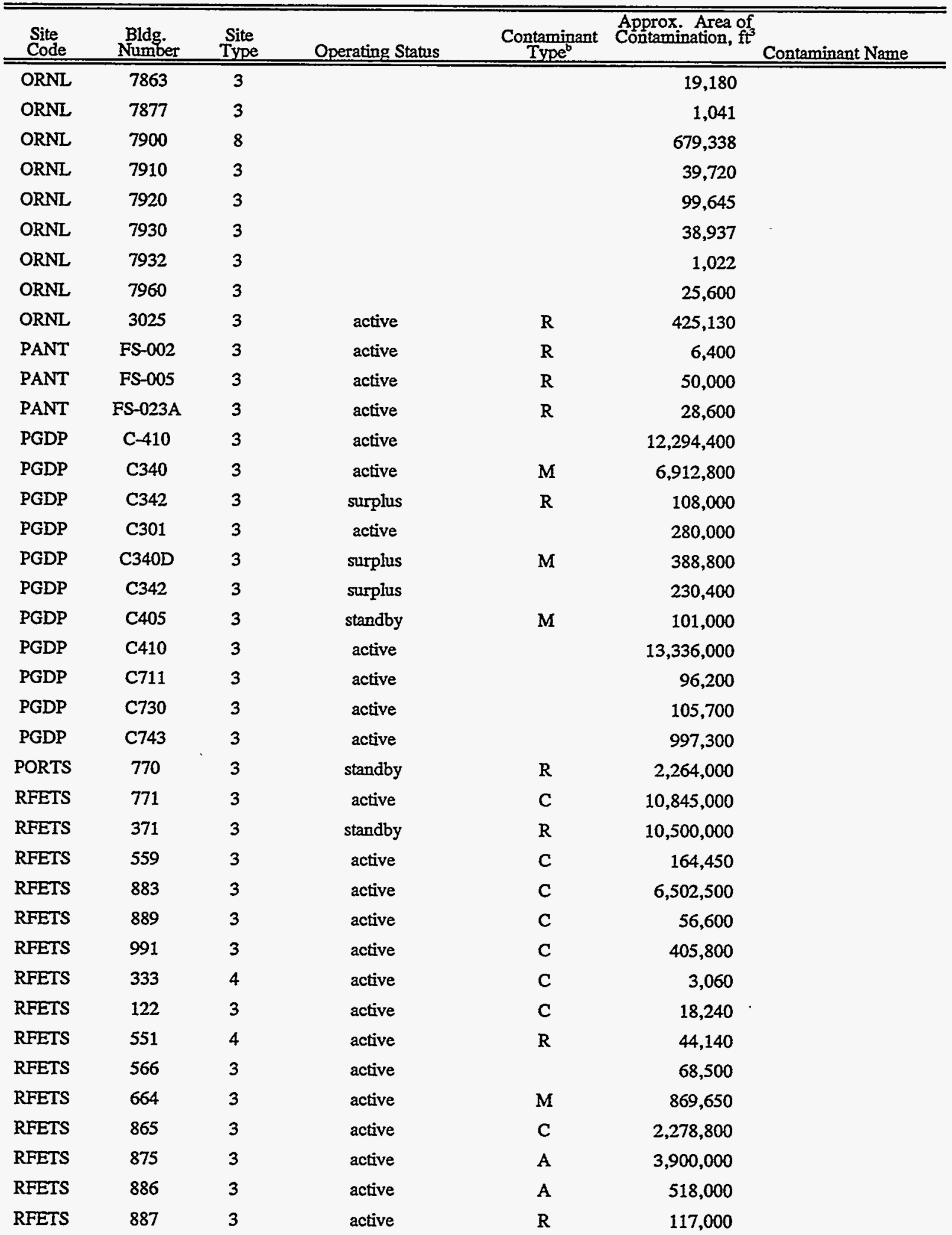


B-31

Table B.2. (continued)

\begin{tabular}{|c|c|c|c|c|c|}
\hline $\begin{array}{l}\text { Site } \\
\text { Code }\end{array}$ & $\begin{array}{c}\text { Bldg. } \\
\text { Number }\end{array}$ & $\begin{array}{l}\text { Site } \\
\text { Type }\end{array}$ & Operating Status & $\begin{array}{c}\text { Contaminant } \\
\text { Type }\end{array}$ & $\begin{array}{l}\text { Approx. Area of } \\
\text { Contamination, } \mathrm{ft}^{3} \\
\text { Contaminant Name }\end{array}$ \\
\hline RFETS & 881 & 3 & active & C & $4,904,000$ \\
\hline RFETS & 707 & 3 & active & c & $11,668,430$ \\
\hline RFETS & 729 & 3 & active & $\mathbf{R}$ & 274,000 \\
\hline RFETS & 770 & 3 & active & $\mathbf{R}$ & 156,000 \\
\hline RFETS & $774 A$ & 4 & active & $\mathbf{R}$ & 180,000 \\
\hline RFETS & 774 & 3 & active & C & $1,253,000$ \\
\hline RFETS & 774B & 3 & active & $\mathrm{R}$ & 180,000 \\
\hline RFETS & 776 & 3 & active & C & $14,839,000$ \\
\hline RFETS & 777 & 3 & active & C & $4,489,200$ \\
\hline RFETS & 779 & 3 & active & c & $3,239,500$ \\
\hline RFETS & 782 & 3 & active & C & 620,000 \\
\hline RFETS & 790 & 3 & active & $\mathbf{R}$ & 6,000 \\
\hline RFETS & 561 & 3 & active & C & 566,000 \\
\hline RFETS & 374 & 3 & active & C & 213,500 \\
\hline RFETS & 444 & 3 & active & C & $3,239,600$ \\
\hline RFETS & 447 & 4 & standby & A & $1,155,000$ \\
\hline RFETS & 985 & 3 & active & A & 238,000 \\
\hline RFETS & 996 & 3 & active & $\mathbf{R}$ & 360,000 \\
\hline RFETS & $566 \mathrm{~A}$ & 3 & active & $\mathrm{U}$ & 400,000 \\
\hline RFETS & 997 & 3 & active & $\mathbf{R}$ & 339,000 \\
\hline RFETS & 998 & 3 & active & $\mathbf{R}$ & 127,000 \\
\hline RFETS & 999 & 3 & active & $\mathbf{R}$ & 221,000 \\
\hline SLAC & 116 & 3 & active & $\mathbf{R}$ & 233,000 \\
\hline SNLL & 824 & 3 & active & $\mathbf{R}$ & 642,500 \\
\hline SNLL & 830 & 3 & active & $\mathbf{R}$ & 400,000 \\
\hline SNLL & 834 & 3 & active & $\mathbf{R}$ & $1,424,000$ \\
\hline SNLL & 844 & 3 & active & $\mathbf{R}$ & 422,000 \\
\hline SNLL & 845 & 3 & active & $\mathbf{R}$ & 545,500 \\
\hline SNLL & 846 & 3 & active & $\mathrm{R}$ & 437,500 \\
\hline SNLL & 847 & 3 & active & $\mathbf{R}$ & 400,000 \\
\hline SNLL & 881 & 3 & active & $\mathbf{R}$ & 221,000 \\
\hline SRS & $1050000 \mathrm{C}$ & 1 & active & $\mathbf{R}$ & $20,493,000$ \\
\hline SRS & $1050000 \mathrm{R}$ & 1 & standby & $\mathbf{R}$ & $10,404,000$ \\
\hline SRS & $1050006 \mathrm{C}$ & 3 & active & $\mathrm{R}$ & 21,600 \\
\hline SRS & $1050007 \mathrm{C}$ & 3 & active & $\mathbf{R}$ & 21,600 \\
\hline SRS & $1080001 R$ & 3 & standby & $\mathrm{R}$ & 329,800 \\
\hline SRS & $1080002 \mathrm{R}$ & 3 & standby & $\mathbf{R}$ & 476,250 \\
\hline SRS & $1100000 \mathrm{C}$ & 3 & active & $\mathbf{R}$ & 9,600 \\
\hline SRS & $1100000 \mathrm{R}$ & 3 & standby & R & 24,000 \\
\hline
\end{tabular}


B-32

Table B.2. (continued)

\begin{tabular}{|c|c|c|c|c|c|}
\hline $\begin{array}{l}\text { Site } \\
\text { Code } \\
\end{array}$ & $\begin{array}{l}\text { Bldg. } \\
\text { Number } \\
\end{array}$ & $\begin{array}{l}\text { Site } \\
\text { Type } \\
\end{array}$ & Operating Status & $\begin{array}{c}\text { Contaminant } \\
\text { Type }\end{array}$ & $\begin{array}{l}\text { Approx. Area of } \\
\text { Contamination, } \mathrm{ft}^{3} \text { Contaminant Name } \\
\end{array}$ \\
\hline SRS & $1510001 \mathrm{R}$ & 3 & active & $\mathbf{R}$ & 307,550 \\
\hline SRS & $1510002 \mathrm{R}$ & 3 & standby & $\mathbf{R}$ & 760,100 \\
\hline SRS & $1810000 \mathrm{R}$ & 3 & standby & $\mathbf{R}$ & 11,520 \\
\hline SRS & $1830001 R$ & 3 & standby & $\mathbf{R}$ & 264,000 \\
\hline SRS & $1830002 \mathrm{R}$ & 3 & standby & $\mathbf{R}$ & 115,000 \\
\hline SRS & $1840002 \mathrm{C}$ & 3 & active & $\mathbf{R}$ & 82,800 \\
\hline SRS & $1910000 \mathrm{C}$ & 3 & active & $\mathbf{R}$ & 11,520 \\
\hline SRS & $2110004 \mathrm{~F}$ & 3 & active & $\mathbf{R}$ & 14,000 \\
\hline SRS & $2210000 \mathrm{~F}$ & 2 & active & $\mathbf{R}$ & $1,883,000$ \\
\hline SRS & $2210000 \mathrm{H}$ & 2 & active & $\mathbf{R}$ & $1,648,000$ \\
\hline SRS & $2320000 \mathrm{~F}$ & 3 & & $\mathbf{R}$ & $1,644,000$ \\
\hline SRS & $2410000 \mathrm{H}$ & 3 & active & $\mathbf{R}$ & 172,500 \\
\hline SRS & $2840000 \mathrm{~F}$ & 3 & active & $\mathbf{R}$ & $3,000,000$ \\
\hline SRS & $2840004 \mathrm{H}$ & 3 & active & $\mathbf{R}$ & 84,000 \\
\hline SRS & $4010001 \mathrm{D}$ & 3 & active & $\mathbf{R}$ & 193,000 \\
\hline SRS & $4010002 \mathrm{D}$ & 3 & active & $\mathbf{R}$ & 30,000 \\
\hline SRS & $4110004 \mathrm{D}$ & 3 & active & $\mathbf{R}$ & 35,200 \\
\hline SRS & $4110006 D$ & 3 & active & $\mathbf{R}$ & 36,000 \\
\hline SRS & $4110007 \mathrm{D}$ & 3 & active & $\mathrm{R}$ & 24,000 \\
\hline SRS & $4120001 D$ & 3 & active & $\mathbf{R}$ & 100,000 \\
\hline SRS & $4120002 \mathrm{D}$ & 3 & active & $\mathbf{R}$ & 216,180 \\
\hline SRS & 4120004D & 3 & active & $\mathbf{R}$ & 109,800 \\
\hline SRS & $4120005 \mathrm{D}$ & 3 & active & $\mathbf{R}$ & 120,000 \\
\hline SRS & $4120006 \mathrm{D}$ & 3 & active & $\mathbf{R}$ & 100 \\
\hline SRS & $4120011 D$ & 3 & active & $\mathbf{R}$ & 10,000 \\
\hline SRS & $4140000 \mathrm{D}$ & 3 & active & $\mathbf{R}$ & 120,000 \\
\hline SRS & $4150000 \mathrm{D}$ & 3 & active & $\mathbf{R}$ & 120,000 \\
\hline SRS & $4210000 \mathrm{D}$ & 3 & active & $\mathbf{R}$ & 81,280 \\
\hline SRS & $6900000 \mathrm{~N}$ & 3 & active & $\mathbf{R}$ & $1,150,000$ \\
\hline SRS & $7010001 R$ & 3 & standby & $\mathbf{R}$ & 374,580 \\
\hline SRS & $7010002 \mathrm{R}$ & 3 & standby & $\mathbf{R}$ & 15,000 \\
\hline SRS & $7010006 \mathrm{G}$ & 3 & active & $\mathbf{R}$ & 14,600 \\
\hline SRS & $7010008 \mathrm{H}$ & 3 & active & $\mathbf{R}$ & 8,000 \\
\hline SRS & $7010014 G$ & 3 & active & $\mathbf{R}$ & 4,800 \\
\hline SRS & $7010015 G$ & 3 & active & $\mathbf{R}$ & 4,800 \\
\hline SRS & $7030004 A$ & 3 & active & $\mathbf{R}$ & 156,000 \\
\hline SRS & $7030006 \mathrm{~A}$ & 3 & active & $\mathbf{R}$ & 153,600 \\
\hline SRS & $7030015 \mathrm{~A}$ & 3 & active & $\mathbf{R}$ & 72,000 \\
\hline SRS & $7030016 A$ & 3 & active & $\mathbf{R}$ & 72,000 \\
\hline
\end{tabular}


B-33

Table B.2. (continued)

\begin{tabular}{|c|c|c|c|c|c|c|}
\hline $\begin{array}{l}\text { Site } \\
\text { Code }\end{array}$ & $\begin{array}{l}\text { Bldg. } \\
\text { Number }\end{array}$ & $\begin{array}{l}\text { Site } \\
\text { Type } \\
\end{array}$ & Operating Status & $\begin{array}{c}\text { Contaminant } \\
\text { Type }^{b}\end{array}$ & $\begin{array}{l}\text { Approx. Area of } \\
\text { Contamination, } \mathrm{ft}^{3}\end{array}$ & Contaminant Name \\
\hline SRS & $7030017 \mathrm{~A}$ & 3 & active & $R$ & 72,000 & \\
\hline SRS & $7030033 \mathrm{~A}$ & 3 & active & $\mathbf{R}$ & 153,600 & \\
\hline SRS & $7030034 \mathrm{~A}$ & 3 & active & $\mathbf{R}$ & 160,000 & \\
\hline SRS & $7030070 \mathrm{~A}$ & 3 & active & $\mathbf{R}$ & 89,600 & \\
\hline SRS & $7040000 \mathrm{R}$ & 3 & standby & $\mathbf{R}$ & $1,269,600$ & \\
\hline SRS & $704 \mathrm{U} 001 \mathrm{Z}$ & 3 & & $\mathbf{R}$ & 4,200 & \\
\hline SRS & $7060000 \mathrm{~A}$ & 3 & active & $\mathbf{R}$ & 60,800 & \\
\hline SRS & $7060000 \mathrm{C}$ & 3 & active & $\mathbf{R}$ & $1,900,000$ & \\
\hline SRS & $7070000 \mathrm{G}$ & 3 & active & $\mathbf{R}$ & 96,100 & \\
\hline SRS & $7170000 \mathrm{G}$ & 3 & active & $\mathrm{R}$ & 324,400 & \\
\hline SRS & $7230005 \mathrm{~A}$ & 3 & active & $\mathbf{R}$ & 38,400 & \\
\hline SRS & $7240006 \mathrm{~A}$ & 3 & active & $\mathbf{R}$ & 38,400 & \\
\hline SRS & $7240007 \mathrm{~A}$ & 3 & active & $\mathbf{R}$ & 38,400 & \\
\hline SRS & 734U000Z & 3 & & $\mathbf{R}$ & 6,500 & \\
\hline SRS & $752 \mathrm{U} 000 \mathrm{Z}$ & 3 & & $\mathrm{R}$ & 87,100 & \\
\hline SRS & $770 \mathrm{U} 000 \mathrm{Z}$ & 8 & & $\mathbf{R}$ & $1,508,000$ & \\
\hline SRS & 771U000Z & 3 & & R & 64,100 & \\
\hline SRS & $7720001 \mathrm{G}$ & 3 & active & $\mathrm{R}$ & 778,600 & \\
\hline SRS & $7720005 \mathrm{G}$ & 3 & active & $\mathbf{R}$ & 66,800 & \\
\hline SRS & $7720013 G$ & 3 & active & $\mathrm{R}$ & 72,000 & \\
\hline SRS & $7720026 \mathrm{G}$ & 3 & active & $\mathrm{R}$ & 20,000 & \\
\hline SRS & $774 \mathrm{U} 000 \mathrm{Z}$ & 3 & & $\mathbf{R}$ & 151,200 & \\
\hline SRS & $787 \mathrm{U} 002 Z$ & 3 & & $\mathbf{R}$ & 38,400 & \\
\hline SRS & $9050037 \mathrm{~F}$ & 3 & active & $\mathbf{R}$ & 48,000 & \\
\hline WSR & 101 & 3 & active & R & $2,830,000$ & \\
\hline WSR & 103 & 3 & active & R & $5,887,600$ & \\
\hline WSR & 104 & 3 & active & R & 49,300 & \\
\hline WSR & 105 & 3 & active & $\mathrm{R}$ & $4,243,600$ & \\
\hline WSR & 108 & 3 & active & $\mathbf{R}$ & 100,000 & \\
\hline WSR & 201 & 3 & active & $\mathbf{R}$ & $6,916,000$ & \\
\hline WSR & 202 & 3 & active & $\mathbf{R}$ & 800,000 & \\
\hline WSR & 301 & 3 & active & R & $6,800,000$ & \\
\hline WSR & 401 & 3 & active & $\mathbf{R}$ & $1,774,500$ & \\
\hline WSR & 403 & 3 & active & $\mathbf{R}$ & $1,780,000$ & \\
\hline WSR & 404 & 3 & active & $\mathbf{R}$ & $1,240,000$ & \\
\hline WSR & 405 & 3 & active & $\mathbf{R}$ & 184,500 & \\
\hline WSR & 406 & 3 & active & $\mathbf{R}$ & $1,601,800$ & \\
\hline WSR & 407 & 3 & active & $\mathbf{R}$ & $5,395,000$ & \\
\hline WSR & 408 & 3 & active & $\mathbf{R}$ & $7,067,800$ & \\
\hline
\end{tabular}


B-34

Table B.2. (continued)

\begin{tabular}{|c|c|c|c|c|c|c|}
\hline $\begin{array}{l}\text { Site } \\
\text { Code } \\
\end{array}$ & $\begin{array}{l}\text { Bldg. } \\
\text { Number }\end{array}$ & $\begin{array}{c}\text { Site } \\
\text { Type } \\
\end{array}$ & Operating Status & $\begin{array}{c}\text { Contaminant } \\
\text { Type }\end{array}$ & $\begin{array}{l}\text { Approx. Area of } \\
\text { Contamination, } \mathrm{ft}^{3} \\
\end{array}$ & Contaminant Name \\
\hline WSR & 410 & 3 & active & $\mathbf{R}$ & $5,210,000$ & \\
\hline WSR & 413 & 3 & active & $\mathbf{R}$ & 145,000 & \\
\hline WSR & 414 & 3 & active & $\mathbf{R}$ & 509,000 & \\
\hline WSR & 417 & 3 & active & $\mathbf{R}$ & 277,200 & \\
\hline WSR & 430 & 3 & active & $\mathbf{R}$ & 62,400 & \\
\hline WSR & 433 & 3 & active & $\mathbf{R}$ & 740,000 & \\
\hline $\mathrm{Y}-12$ & $9201-04$ & 3 & surplus & & $44,952,000$ & lithrum hydroxide \\
\hline$Y-12$ & $9201-04$ & 3 & surplus & & $44,952,000$ & mercury \\
\hline $\mathrm{Y}-12$ & $9201-04$ & 3 & surplus & & $44,952,000$ & (1,1-biphenyl)-4-amine \\
\hline$Y-12$ & $9201-04$ & 3 & surplus & & $44,952,000$ & lead \\
\hline$Y-12$ & $9201-04$ & 3 & surplus & & $44,952,000$ & asbestos \\
\hline Y-12 & $9419-1$ & 3 & surphus & & 100,000 & \\
\hline$Y-12$ & $9201-5$ & 3 & & & $45,169,000$ & \\
\hline $\mathrm{Y}-12$ & $9201-5 N$ & 3 & & & $6,842,500$ & \\
\hline$Y-12$ & 9202 & 3 & & - & $6,440,000$ & \\
\hline $\mathrm{Y}-12$ & 9203 & 3 & & & 308,000 & \\
\hline Y-12 & 9204-1 & 3 & & & 885,600 & \\
\hline$Y-12$ & $9201-1$ & 3 & & & 526,256 & \\
\hline$Y-12$ & $9201-3$ & 3 & & & $4,495,200$ & \\
\hline$Y-12$ & 9206 & 3 & & & $6,594,812$ & \\
\hline$Y-12$ & 9210 & 3 & & . & 65,700 & \\
\hline$Y-12$ & 9212 & 3 & & & $7,783,125$ & \\
\hline$Y-12$ & $9204-2 E$ & 3 & & & $1,512,000$ & \\
\hline$Y-12$ & $9204-3$ & 3 & & & $3,489,300$ & \\
\hline$Y-12$ & $9204-4$ & 3 & & & $24,644,700$ & \\
\hline$Y-12$ & 9213 & 8 & & & 940,000 & \\
\hline$Y-12$ & 9215 & 3 & & & $14,915,000$ & \\
\hline $\mathrm{Y}-12$ & $9217-1$ & 3 & & & 135,000 & \\
\hline $\mathrm{Y}-12$ & $9401-1$ & 3 & & & 300,000 & \\
\hline$Y-12$ & $9401-4$ & 3 & & & 198,000 & \\
\hline $\mathrm{Y}-12$ & $9401-5$ & 3 & & & 300,000 & \\
\hline$Y-12$ & $9720-3$ & 3 & & & 126,000 & \\
\hline$Y-12$ & $9720-5$ & 3 & & & $5,128,005$ & \\
\hline$Y-12$ & $9720-33$ & 3 & & & $3,391,755$ & \\
\hline$Y-12$ & $9720-38$ & 3 & & & 385,000 & \\
\hline$Y-12$ & $9723-19$ & 3 & & & 75,000 & \\
\hline$Y-12$ & 9728 & 3 & & & 408,000 & \\
\hline$Y-12$ & 9731 & 3 & & & 559,500 & \\
\hline$Y-12$ & $9732-1$ & 3 & $\cdot$ & & 4,000 & \\
\hline
\end{tabular}




\section{B-35}

Table B.2. (continued)

\begin{tabular}{|c|c|c|c|c|c|}
\hline $\begin{array}{l}\text { Site } \\
\text { Code }\end{array}$ & $\begin{array}{l}\text { Bldg. } \\
\text { Number }\end{array}$ & $\begin{array}{l}\text { Site } \\
\text { Type }\end{array}$ & Operating Status & $\begin{array}{c}\text { Contaminant } \\
\text { Type }^{b}\end{array}$ & $\begin{array}{l}\text { Approx. Area of } \\
\text { Contamination, } \mathrm{ft}^{3} \text { Contaminant Name }\end{array}$ \\
\hline $\mathrm{Y}-12$ & 9735 & 3 & & & 30,200 \\
\hline$Y-12$ & $9767-2$ & 3 & & & 117,600 \\
\hline$Y-12$ & 9980 & 3 & & & 590,000 \\
\hline$Y-12$ & 9995 & 3 & & & $2,100,000$ \\
\hline$Y-12$ & 9998 & 3 & & & $10,282,500$ \\
\hline $\mathrm{Y}-12$ & $81-10$ & 3 & & & 750,000 \\
\hline$Y-12$ & $9720-17$ & 3 & & & 410,000 \\
\hline$Y-12$ & $9720-13$ & 3 & active & $\mathrm{R}$ & 107,000 \\
\hline$Y-12$ & $9720-14$ & 3 & active & $\mathbf{R}$ & 240,000 \\
\hline$Y-12$ & $9720-18$ & 3 & active & $\mathbf{R}$ & 605,000 \\
\hline $\mathrm{Y}-12$ & $9720-22$ & 3 & active & $\mathbf{R}$ & $1,600,000$ \\
\hline$Y-12$ & $9720-24$ & 3 & active & $\mathbf{R}$ & $1,120,000$ \\
\hline$Y-12$ & ISOLATBN & 3 & active & R & 30,220 \\
\hline$Y-12$ & ISOTOPE. & 3 & active & $\mathbf{R}$ & 95,200 \\
\hline$Y-12$ & LGANFC & 3 & active & $\mathbf{R}$ & 564,100 \\
\hline $\mathrm{Y}-12$ & MERTOFBC & 3 & standby & $\mathbf{R}$ & 50,280 \\
\hline $\mathrm{Y}-12$ & MG2 & 3 & active & $\mathbf{R}$ & 14,400 \\
\hline$Y-12$ & TG1 & 3 & active & $\mathbf{R}$ & 107,500 \\
\hline$Y-12$ & TWINEBN & 3 & active & $\mathbf{R}$ & 8,400 \\
\hline$Y-12$ & TWINWBN & 3 & active & $\mathbf{R}$ & 8,400 \\
\hline$Y-12$ & VDRIFBD & 3 & active & $\mathbf{R}$ & 362,300 \\
\hline $\mathrm{Y}-12$ & VDRIFSD & 3 & active & $\underline{\mathbf{R}}$ & 100.800 \\
\hline
\end{tabular}

"Site Type: $1=$ production reactor

$2=$ other reactor

$3=$ other radiologically contaminated building

4 = non-radiological contaminated building

7 = gaseous diffusion plant

8 = research reactor

${ }^{b}$ Contaminant Type: $\mathrm{N}=$ nuclear

$$
\begin{aligned}
& M=\text { mixed radiological } \\
& R=\text { radiological } \\
& U=\text { unknown } \\
& C=\text { chemical } \\
& A=\text { asbestos }
\end{aligned}
$$

SLAC = Stanford Linear Accelerator

Note: blank spaces indicate no information in the data base. 
Table B.3. Technology needs assessment for concrete decontamination at DOE sites

\begin{tabular}{|c|c|c|c|c|}
\hline Facility and Site & Media & $\begin{array}{c}\text { Contaminant, Concentration, and } \\
\text { Volume }\end{array}$ & $\begin{array}{c}\text { Technology, Vendor }{ }^{a}, \text { Evaluation, and } \\
\text { Schedule }\end{array}$ & Comments \\
\hline \multicolumn{5}{|l|}{ Argonne National Laboratory } \\
\hline $\begin{array}{l}\text { Experimental Boiling } \\
\text { Water Reactor }\end{array}$ & Masonry debris & $\begin{array}{l}\text { LLW: } 560 \mathrm{yd}^{3} \\
\text { Asbestos: } 100 \mathrm{yd}^{3} \\
\text { Pb: } 60,000 \mathrm{lb} \\
\text { Concentrations unknown }\end{array}$ & $\begin{array}{l}\text { Technology: not given. } \\
\text { Evaluation: need cheaper, less labor- } \\
\text { intensive decontamination methods } \\
\text { that will meet free-release criterion. } \\
\text { Schedule: technology needed as soon } \\
\text { as possible. Work about } 50 \% \\
\text { completed (as of } 8 / 91 \text { ). }\end{array}$ & $\begin{array}{l}\text { Most information obtained from ER } \\
\text { and WM site-specific plan, January } \\
1990 .\end{array}$ \\
\hline $\begin{array}{l}\text { Central Liquid Processing } \\
\text { Area }^{b}\end{array}$ & Soil & $\begin{array}{l}{ }^{137} \mathrm{Cs} \\
\text { Volume: } 170 \mathrm{~m}^{3} \\
\text { Concentration unknown. }\end{array}$ & $\begin{array}{l}\text { Technology: disposal at INEL Radio- } \\
\text { active Waste Management Complex. } \\
\text { Schedule: technology needed } \\
\text { September } 1994 \text {. }\end{array}$ & $\begin{array}{l}\text { Information obtained from ER and } \\
\text { WM site-specific plan, January } 1990 .\end{array}$ \\
\hline WAG-9 activities & $\begin{array}{l}\text { Concrete and } \\
\text { others }\end{array}$ & $\begin{array}{l}{ }^{137} \mathrm{Cs}: 29,110 \mathrm{pCi} / \mathrm{g} \\
\text { Other radionuclides, volatile } \\
\text { organic compounds, PCBs, } \\
\text { dioxins and furans, heavy metals; } \\
\text { concentrations unknown. } \\
\text { Volume: unknown. }\end{array}$ & $\begin{array}{l}\text { Technology: } \\
\text { 1. disposal of LLW at INEL } \\
\text { Radioactive Waste Management } \\
\text { Complex } \\
\text { 2. disposal of hazardous waste at an } \\
\text { EPA-approved facility. } \\
\text { Vendor: F } \\
\text { Schedule: technology required } \\
\text { October } 1992 .\end{array}$ & $\begin{array}{l}\text { Mixed waste must be dealt with on a } \\
\text { case-by-case basis. }\end{array}$ \\
\hline $\begin{array}{l}\text { CP-5 Reactor biological } \\
\text { shield }\end{array}$ & Masonry debris & \begin{tabular}{|l|} 
LLW \\
${ }^{60} \mathrm{Co}: 10 \mathrm{Ci}$ \\
${ }^{3} \mathrm{H}: 10 \mathrm{Ci}$ \\
Total volume: $\quad 12,500 \mathrm{ft}^{3}$
\end{tabular} & $\begin{array}{l}\text { Technology: existing technologies } \\
\text { (none specified). } \\
\text { Evaluation: neither cost nor radiation } \\
\text { exposure are minimized. } \\
\text { Schedule: technology needed FY95. }\end{array}$ & None \\
\hline
\end{tabular}


Table B.3. (continued)

\begin{tabular}{|c|c|c|c|c|}
\hline Facility and Site & Media & $\begin{array}{l}\text { Contaminant, Concentration, and } \\
\text { Volume }\end{array}$ & $\begin{array}{l}\text { Technology, Vendor }{ }^{a}, \text { Evaluation, and } \\
\text { Schedule }\end{array}$ & Comments \\
\hline \multicolumn{5}{|l|}{$\begin{array}{l}\text { Battelle Columbus } \\
\text { Laboratories }\end{array}$} \\
\hline Decommissioning project & $\begin{array}{l}\text { Concrete debris } \\
\text { and others }\end{array}$ & $\begin{array}{l}\text { LLW and TRU: } 1 \text { to } 10 \mathrm{mCi} \\
\text { and above. } \\
\text { Volume: unknown }\end{array}$ & $\begin{array}{l}\text { Technology and evaluation: } \\
\text { 1. remote handling and disposal of } \\
\text { TRU waste } \\
\text { 2. decontamination by chemical treat- } \\
\text { ment, abrasives, or high-pressure } \\
\text { water: technology is costly, poses } \\
\text { risk to workers, and generates } \\
\text { secondary waste. } \\
\text { Vendors: A, B, C } \\
\text { Schedule: D\&D ongoing through } \\
\text { FY97; technology needed in FY93. }\end{array}$ & $\begin{array}{l}\text { Characterization needs: } \\
\text { 1. reduced sample size } \\
\text { 2. remote operation } \\
\text { 3. real-time results } \\
\text { Battelle facilities are under NRC } \\
\text { license. }\end{array}$ \\
\hline \multicolumn{5}{|l|}{$\begin{array}{l}\text { Brookhaven National } \\
\text { Laboratory }\end{array}$} \\
\hline Former landfill ${ }^{b}$ & $\begin{array}{l}\text { Construction } \\
\text { debris (soil and } \\
\text { groundwater) }\end{array}$ & $\begin{array}{l}\text { LLW: concentration and } \\
\text { volume unknown }\end{array}$ & $\begin{array}{l}\text { Technology: impermeable cap. } \\
\text { Vendor: F } \\
\text { Evaluation: interim remedy only. } \\
\text { Schedule: landfill closed } \\
\text { December } 1990 \text {. RI/FS scope of } \\
\text { work in preparation; ROD expected } \\
\text { 1995. }\end{array}$ & $\begin{array}{l}\text { Landfill is unlined. Construction } \\
\text { debris commingled with animal } \\
\text { carcasses and sewage sludge. } \\
\text { Characterization is incomplete. An } \\
\text { IAG between DOE, EPA, and New } \\
\text { York state covering CERCLA and } \\
\text { RCRA issues has been signed. }\end{array}$ \\
\hline
\end{tabular}


Table B.3. (continued)

\begin{tabular}{|c|c|c|c|c|}
\hline Facility and Site & Media & $\begin{array}{c}\text { Contaminant, Concentration, and } \\
\text { Volume }\end{array}$ & $\begin{array}{c}\text { Technology, Vendor } a, \text { Evaluation, and } \\
\text { Schedule }\end{array}$ & Comments \\
\hline \multicolumn{5}{|l|}{$\begin{array}{l}\text { Fernald Feed Materials } \\
\text { Production Center }\end{array}$} \\
\hline OU $1^{b}$ & $\begin{array}{l}\text { Buried material, } \\
\text { including } \\
\text { construction } \\
\text { debris }\end{array}$ & $\begin{array}{l}\text { LLW, } \mathrm{U}, \mathrm{Th} \text {, sulfates: } \\
\text { concentrations unknown. } \\
\text { Volume: } 448,139 \mathrm{yd}^{3} \text { waste; } \\
95,519 \mathrm{yd}^{3} \text { cap material; } \\
690,885 \mathrm{yd}^{3} \text { soil. }\end{array}$ & $\begin{array}{l}\text { Technology: } \\
\text { 1. off-site treatment and disposal } \\
\text { 2. in-place treatment (grouting/shallow } \\
\text { land mixing, in situ vitrification) } \\
\text { 3. isolation in place (slurry wall, } \\
\text { cryogenic wall, RCRA capping, } \\
\text { flexible membrane liners, } \\
\text { surcharging) } \\
\text { 4. retrieval methods. } \\
\text { Evaluation: } \\
\text { The favored alternative (as of } 1 / 93 \text { ) is } \\
\text { removal and stabilization with on-site } \\
\text { disposal. Removal could be done } \\
\text { remotely, mechanically, or as a slurry. } \\
\text { Waste would then require } \\
\text { stabilization, probably by grouting or } \\
\text { possibly vitrification. } \\
\text { Schedule: ROD is due to EPA } \\
\text { December } 1994 \text {. Remediation must } \\
\text { start summer of } 1996 \text {. }\end{array}$ & $\begin{array}{l}\text { OU } 1 \text { contains six sludge/waste pits } \\
\text { that received mostly uranium proces- } \\
\text { sing wastes. Some } 55 \text {-gal drums and } \\
\text { construction debris are also in the } \\
\text { pits. A few pits have been covered } \\
\text { with soil caps, but the caps have } \\
\text { been difficult to maintain because of } \\
\text { the instability of the buried wastes, } \\
\text { which have a "peanut butter" consis- } \\
\text { tency. No clean-up levels have been } \\
\text { set (as of } 1 / 93 \text { ). }\end{array}$ \\
\hline OU 3 & \begin{tabular}{|l|} 
Buildings and \\
other debris
\end{tabular} & $\begin{array}{l}\text { U, Th, asbestos: low level } \\
\text { Total volume: } \sim 800,000 \mathrm{yd}^{3}\end{array}$ & $\begin{array}{l}\text { Technology and Evaluation: } \\
\text { 1. D\&D off-site disposal: } \\
\text { decontamination causes large } \\
\text { secondary waste stream } \\
\text { 2. D\&D on-site disposal: } \\
\text { decontamination causes large } \\
\text { secondary waste stream. } \\
\text { Schedule: ROD expected in FY98. }\end{array}$ & $\begin{array}{l}\text { Materials in this subunit are build- } \\
\text { ings, scrap metal piles, and drums } \\
\text { of mixed waste that are being stored. } \\
\text { Generally, adequate technology } \\
\text { exists to address the facility-related } \\
\text { materials; however, procedures } \\
\text { typically generate large quantities } \\
\text { of secondary waste. }\end{array}$ \\
\hline
\end{tabular}


Table B.3. (continued)

\begin{tabular}{|c|c|c|c|c|}
\hline Facility and Site & Media & $\begin{array}{c}\text { Contaminant, Concentration, and } \\
\text { Volume }\end{array}$ & $\begin{array}{c}\text { Technology, Vendor } \\
\text { Schedule Evaluation, and }\end{array}$ & Comments \\
\hline \multicolumn{5}{|l|}{$\begin{array}{l}\text { Formerly Utilized Sites } \\
\text { Remedial Action Project }\end{array}$} \\
\hline $\begin{array}{l}\text { Building/masonry at } \\
\text { non-New Jersey FUSRAP } \\
\text { sites }\end{array}$ & Masonry debris & $\begin{array}{l}\mathrm{U},{ }^{26} \mathrm{Ra},{ }^{232} \mathrm{Th}, \mathrm{Pb}, \mathrm{As} \text {, asbestos: } \\
\text { concentrations unknown. } \\
\text { PCBs: up to } 450 \mathrm{ppm} \text {. } \\
\text { Volume: } 10,000 \text { to } 100,000 \mathrm{yd}^{3} ; \\
300 \text { drums of radioactive waste, } \\
200 \text { drums of mixed waste. }\end{array}$ & $\begin{array}{l}\text { Technology: } \\
\text { 1. chemical leaching and etching } \\
\text { 2. high-pressure water } \\
\text { 3. homogenization of material } \\
\text { 4. scabbling. } \\
\text { Vendors: A, C, E } \\
\text { Schedule: ROD } 1994 \text { to } 1998 \text { for } \\
\text { New York and Missouri; remainder } \\
\text { of sites' remediation schedules are } \\
\text { from present to } 2005 \text {. }\end{array}$ & $\begin{array}{l}\text { Contamination on surface and } \\
\text { beneath buildings; many are active } \\
\text { industrial facilities. Some buildings } \\
\text { contain chemical wastes. Near large } \\
\text { populations. } \\
\text { Characterization needs: } \\
\text { 1. field analytical techniques } \\
\text { 2. methods for characterization of } \\
\text { structures with unstable roofs } \\
\text { 3. probes to sample in isolated } \\
\text { areas. }\end{array}$ \\
\hline $\begin{array}{l}\text { Hanford Reservation } \\
100 \text { Area reactor cores }\end{array}$ & $\begin{array}{l}\text { Masonry debris } \\
\text { and others }\end{array}$ & $\begin{array}{l}\text { Radioactive graphite, } \mathrm{Pb}, \\
\text { concrete, steel, asbestos: } \\
\text { concentrations unknown } \\
\text { ("locally high"). } \\
\text { Volume: estimated } 37,000 \mathrm{ft}^{3} \text {. }\end{array}$ & $\begin{array}{l}\text { Technology: not given. } \\
\text { Evaluation: approach is developed. } \\
\text { Schedule: not given. }\end{array}$ & $\begin{array}{l}\text { Waste will result from } D \& D \text { of } \\
\text { reactors. No cores decommissioned } \\
\text { as of } 1 / 93 \text {. Potential radiologic } \\
\text { hazard to workers. }\end{array}$ \\
\hline $\begin{array}{l}200 \text { Area chemical process } \\
\text { facilities }\end{array}$ & $\begin{array}{l}\text { Masonry debris } \\
\text { and others }\end{array}$ & $\begin{array}{l}\text { TRU (20\%); LLW (80\%) } \\
\text { Concentrations: extremely high } \\
\text { within structures. } \\
\text { Volume: } 630,000 \mathrm{yd}^{3}\end{array}$ & \begin{tabular}{|l|} 
Technology and evaluation: \\
1. removal and dismantlement: \\
massive structures preclude use of \\
conventional demolition techniques. \\
2. disposal: high cost for disposal of \\
large volume of material. Need \\
decontamination method for release \\
of concrete rubble. \\
3. entombment in place: may not be \\
acceptable to regulators due to large \\
radionuclide inventory. Need \\
regulator-approved methods for \\
post-D\&D monitoring. \\
Schedule: effluent treatment \\
facilities to be upgraded by $6 / 95 ;$ \\
U-Plant and REDOX start date is \\
2007.
\end{tabular} & $\begin{array}{l}\text { Technology is proven and currently } \\
\text { available but very costly and has a } \\
\text { risk of high worker exposure. } \\
\text { D\&D activity includes six canyon } \\
\text { buildings. }\end{array}$ \\
\hline
\end{tabular}


Table B.3. (continued)

\begin{tabular}{|c|c|c|c|c|}
\hline Facility and Site & Media & $\begin{array}{c}\text { Contaminant, Concentration, and } \\
\text { Volume }\end{array}$ & $\begin{array}{c}\text { Technology, Vendor }{ }^{a}, \text { Evaluation, and } \\
\text { Schedule }\end{array}$ & Comments \\
\hline \multicolumn{5}{|l|}{$\begin{array}{l}\text { Idaho National Engincering } \\
\text { Laboratory }\end{array}$} \\
\hline $\begin{array}{l}\text { PBF corrosive } \\
\text { sump/evaporation pond }\end{array}$ & Concrete & $\begin{array}{l}{ }^{137} \mathrm{Cs}, \mathrm{Cr}^{3+} \text {; concentrations } \\
\text { unknown; volume is risk-based. } \\
\text { Removal volume estimated at } \\
\leq 100 \mathrm{yd}^{3}\end{array}$ & $\begin{array}{l}\text { Technology: no new technology } \\
\text { required. } \\
\text { Schedule: ROD FY92. }\end{array}$ & None \\
\hline Borax-01 buried reactor & $\begin{array}{l}\text { Buried debris } \\
\text { (not specified). }\end{array}$ & $\begin{array}{l}\text { Reactor products, low level, } \\
\text { volume unknown. }\end{array}$ & $\begin{array}{l}\text { Technology: not given. } \\
\text { Schedule: characterization activities } \\
\text { will begin in FY95; ROD FY2001. }\end{array}$ & $\begin{array}{l}\text { Building that contained a decon- } \\
\text { taminated reactor is buried. } \\
\text { Institutional controls currently in } \\
\text { place are necessary to avoid worker } \\
\text { exposure. }\end{array}$ \\
\hline $\begin{array}{l}\text { PBF brine } \\
\text { tank/evaporation pond }\end{array}$ & No information & $\begin{array}{l}{ }^{137} \mathrm{Cs},{ }^{134} \mathrm{Cs}: \text { concentrations } \\
\text { unknown. } \\
\mathrm{H}_{2} \mathrm{SO}_{4}: 35,950 \mathrm{lb} \\
\mathrm{NaOH}: 40,350 \mathrm{lb} \\
\mathrm{Cr}^{3+}, \mathrm{Cr}^{6+} \text { : concentrations } \\
\text { unknown. } \\
\text { Total volume: } 300 \text { to } 400 \mathrm{yd}^{3} \text {; } \\
\text { areal extent } 25,500 \mathrm{ft}^{2} \text {. }\end{array}$ & $\begin{array}{l}\text { Technology and evaluation: soil wash- } \\
\text { ing, questionable effectiveness for this } \\
\text { site; will be technology demonstration } \\
\text { to determine applicability to other } \\
\text { sites. } \\
\text { Schedule: ROD FY92. }\end{array}$ & None. \\
\hline D\&D Program & Masonry debris & $\begin{array}{l}\text { Low-level contamination of } \\
\text { concrete; volume unknown. }\end{array}$ & $\begin{array}{l}\text { Technology: acid washing, scabbling. } \\
\text { Vendor: } \mathrm{E} \\
\text { Evaluation: labor intensive. } \\
\text { Schedule: as soon as possible. }\end{array}$ & $\begin{array}{l}\text { If concrete cannot be decontami- } \\
\text { nated, large volumes of rubble will } \\
\text { require permanent disposal in a } \\
\text { repository. }\end{array}$ \\
\hline
\end{tabular}


Table B.3. (continued)

\begin{tabular}{|c|c|c|c|c|}
\hline Facility and Site & Media & $\begin{array}{c}\text { Contaminant, Concentration, and } \\
\text { Volume }\end{array}$ & $\begin{array}{l}\text { Technology, Vendor }{ }^{a}, \text { Evaluation, and } \\
\text { Schedule }\end{array}$ & Comments \\
\hline \multicolumn{5}{|l|}{ INEL (continued) } \\
\hline Mixed Waste Program & Debris & $\begin{array}{l}\mathrm{Cr}, \mathrm{Hg}, \mathrm{Pb} \text {, asbestos, nitric and } \\
\text { hydrofluoric acids, }{ }^{60} \mathrm{Co},{ }^{137} \mathrm{Cs}, \\
{ }^{90} \mathrm{Sr} \text { : concentrations unknown } \\
\text { Volume: unknown. }\end{array}$ & $\begin{array}{l}\text { Technology: not given } \\
\text { Evaluation: deficiencies exist } \\
\text { Schedule: as soon as possible. }\end{array}$ & $\begin{array}{l}\text { D\&D processes result in mixed } \\
\text { wastes. } \\
\text { Large volumes make treatment } \\
\text { difficult and expensive. Limited } \\
\text { existing disposal capacities and } \\
\text { difficulty maintaining regulatory } \\
\text { compliance further complicate } \\
\text { handling of mixed wastes. }\end{array}$ \\
\hline \multicolumn{5}{|l|}{$\begin{array}{l}\text { Inhalation Toxicology } \\
\text { Research Institute }\end{array}$} \\
\hline Hot ponds & Masonry debris & $\begin{array}{l}\text { LLW } \\
\text { Concentration: low } \\
\text { Volume: low }\end{array}$ & $\begin{array}{l}\text { Technology: not given. } \\
\text { Evaluation: no deficiencies; simple, } \\
\text { proven technologies available. } \\
\text { Schedule: remediation complete in } \\
\text { five years (as of } 1 / 93 \text { ). }\end{array}$ & $\begin{array}{l}\text { Surface contamination of concrete } \\
\text { and masonry debris of former D\&D } \\
\text { hot ponds. } \\
\text { ITRI provides a good experimental } \\
\text { area for development of technolo- } \\
\text { gies that may be used elsewhere. } \\
\text { This project is in the remediation } \\
\text { phase and ncaring completion (as of } \\
1 / 93 \text { ). Monitoring will continue. }\end{array}$ \\
\hline
\end{tabular}


Table B.3. (continued)

\begin{tabular}{|c|c|c|c|c|}
\hline Facility and Site & Media & $\begin{array}{c}\text { Contaminant, Concentration, and } \\
\text { Volume }\end{array}$ & $\begin{array}{c}\text { Technology, Vendor }{ }^{a} \text {, Evaluation, and } \\
\text { Schedule }\end{array}$ & Comments \\
\hline \multicolumn{5}{|l|}{$\begin{array}{l}\text { Lawrence Livermore } \\
\text { National Laboratory }\end{array}$} \\
\hline $\begin{array}{l}\text { Buildings } 212,412,281 \text {, } \\
\text { and } 292\end{array}$ & $\begin{array}{l}\text { Concrete and } \\
\text { other debris }\end{array}$ & $\begin{array}{l}\text { Fission products, }{ }^{3} \mathrm{H},{ }^{5} \mathrm{Fe}, \mathrm{TRU}, \\
\text { activation products. } \\
\text { Concentrations: low to } \\
\text { moderate. } \\
\text { Volume: four buildings. }\end{array}$ & $\begin{array}{l}\text { Technology: not given. } \\
\text { Evaluation: not given. } \\
\text { Schedule: unknown. }\end{array}$ & $\begin{array}{l}\text { Four buildings to D\&D: } \\
\text { 1. Bldg. } 212: \text { cyclotron accelerator } \\
\text { and neutron accelerator have } \\
\text { residual surface contamination of } \\
\text { activation products. } \\
\text { 2. Bldg. } 412: \text { six hot cells with } \\
\text { fission products. } \\
\text { 3. Bldg. } 281 \text { : nuclear test reactor, } \\
\text { water-cooled with contaminated } \\
\text { cooling lines and shielding } \\
\text { materiais. } \\
\text { 4. Bldg. } 292: \text { rotating target neu- } \\
\text { tron source }\left({ }^{3} \mathrm{H}\right) \text {, magnetofusion } \\
\text { energy research. } \\
\text { These facilities could be used for } \\
\text { other applications if effectively } \\
\text { decontaminated. The buildings pose } \\
\text { little current risk for radioactive } \\
\text { rclease and are located on site. }\end{array}$ \\
\hline Tritium in soils & Concrete and soil & $\begin{array}{l}\text { Low-level radiation, }{ }^{3} \mathrm{H} . \\
\text { Concentrations: }{ }^{3} \mathrm{H} \text { up to } \\
2.6 \times 10^{8} \mathrm{pCi} / \mathrm{L} \text { in soil } \\
\text { moisture. } \\
\text { Volume: unknown. }\end{array}$ & $\begin{array}{l}\text { Technology: not given; under current } \\
\text { regulations, plans are only to monitor } \\
\text { tritium migration. } \\
\text { Schedule: not given. }\end{array}$ & $\begin{array}{l}\text { Contamination is in a hard-to-access, } \\
\text { high-use area. }\end{array}$ \\
\hline
\end{tabular}


Table B.3. (continued)

\begin{tabular}{|c|c|c|c|c|}
\hline Facility and Site & Media & $\begin{array}{l}\text { Contaminant, Concentration, and } \\
\text { Volume }\end{array}$ & $\begin{array}{c}\text { Technology, Vendor }{ }^{-}, \text {Evaluation, and } \\
\text { Schedule }\end{array}$ & Comments \\
\hline $\begin{array}{l}\text { Los Alamos National } \\
\text { Laboratory } \\
\text { Contaminated structures }\end{array}$ & $\begin{array}{l}\text { Concrete and } \\
\text { others }\end{array}$ & $\begin{array}{l}\text { LLW, hazardous organic } \\
\text { compounds, metals, mixed waste, } \\
\text { asbestos, high explosives. } \\
\text { Concentrations and volume: } \\
\text { unknown. }\end{array}$ & $\begin{array}{l}\text { Technology: not given. } \\
\text { Evaluation: deficiencies exist. } \\
\text { Schedule: need characterization } \\
\text { technologies within two years (as of } \\
1 / 93 \text { ). Remedial action time frame is } \\
2005 \text { through } 2012 \text {. }\end{array}$ & $\begin{array}{l}\text { Includes both buried and surface } \\
\text { structures. } \\
\text { Detection limits must meet DOT } \\
\text { shipping requirements and NRC- } \\
\text { licensed analytical lab requirements } \\
\text { (10 nCi/L). } \\
\text { Need rapid radioactivity and dose } \\
\text { rate measurements for radiological } \\
\text { waste samples and wastes for } \\
\text { transport off site for treatment, } \\
\text { disposal, or analysis. }\end{array}$ \\
\hline $\begin{array}{l}\text { Oak Ridge National } \\
\text { Laboratory } \\
\text { Gaseous diffusion plants } \\
\text { (Paducah, Portsmouth, } \\
\text { K-25) }\end{array}$ & $\begin{array}{l}\text { Masonry debris } \\
\text { and metals }\end{array}$ & $\begin{array}{l}\text { U, PCBs, Cr, Tc, Pb, dioxin, } \\
\text { asbestos, daughter products, oils. } \\
\text { Concentrations: uranium } \\
\text { present from trace to Class C } \\
\text { (no definition of Class C given). } \\
\\
\text { Volume: K-25 is the largest } \\
\text { D\&D project in the DOE } \\
\text { system. Asbestos: } 205,000 \mathrm{ft}^{3} \text {, } \\
\text { (over } 21 \text { miles of pipc); PCBs: } \\
>225,000 \text { gal + } 20,000 \text { PCB- } \\
\text { laden ventilating gaskets; } \\
162,000 \text { gal of coolants; } \\
279,000 \text { gal of lube oil. }\end{array}$ & $\begin{array}{l}\text { Technology and evaluation: } \\
\text { 1. pelletized gas: more abrasion } \\
\text { needed } \\
\text { 2. microwave scabbling } \\
\text { 3. scabbling } \\
\text { 4. scrubbing } \\
\text { 5. ultra-high-pressure water: water } \\
\text { recycle needed. } \\
\text { Vendors: D, C, E } \\
\text { Schedule: process equipment removal } \\
\text { FY2002 to } 2010 \text {. Other D\&D } \\
\text { activities FY2011 to } 2016 \text {. }\end{array}$ & $\begin{array}{l}\text { D\&D includes cooling towers and } \\
\text { underground pipelines. An inde- } \\
\text { pendent study is being conducted on } \\
\text { how this cleanup will be handled. } \\
\text { The recoverable value of nickel is } \\
\text { estimated to be } \$ 1 \text { billion. } \\
\text { Characterization needs: } \\
\text { 1. non-destructive assaying } \\
\text { techniques } \\
\text { 2. PCB sniffer (field analytical } \\
\text { equipment). }\end{array}$ \\
\hline
\end{tabular}


Table B.3. (continued)

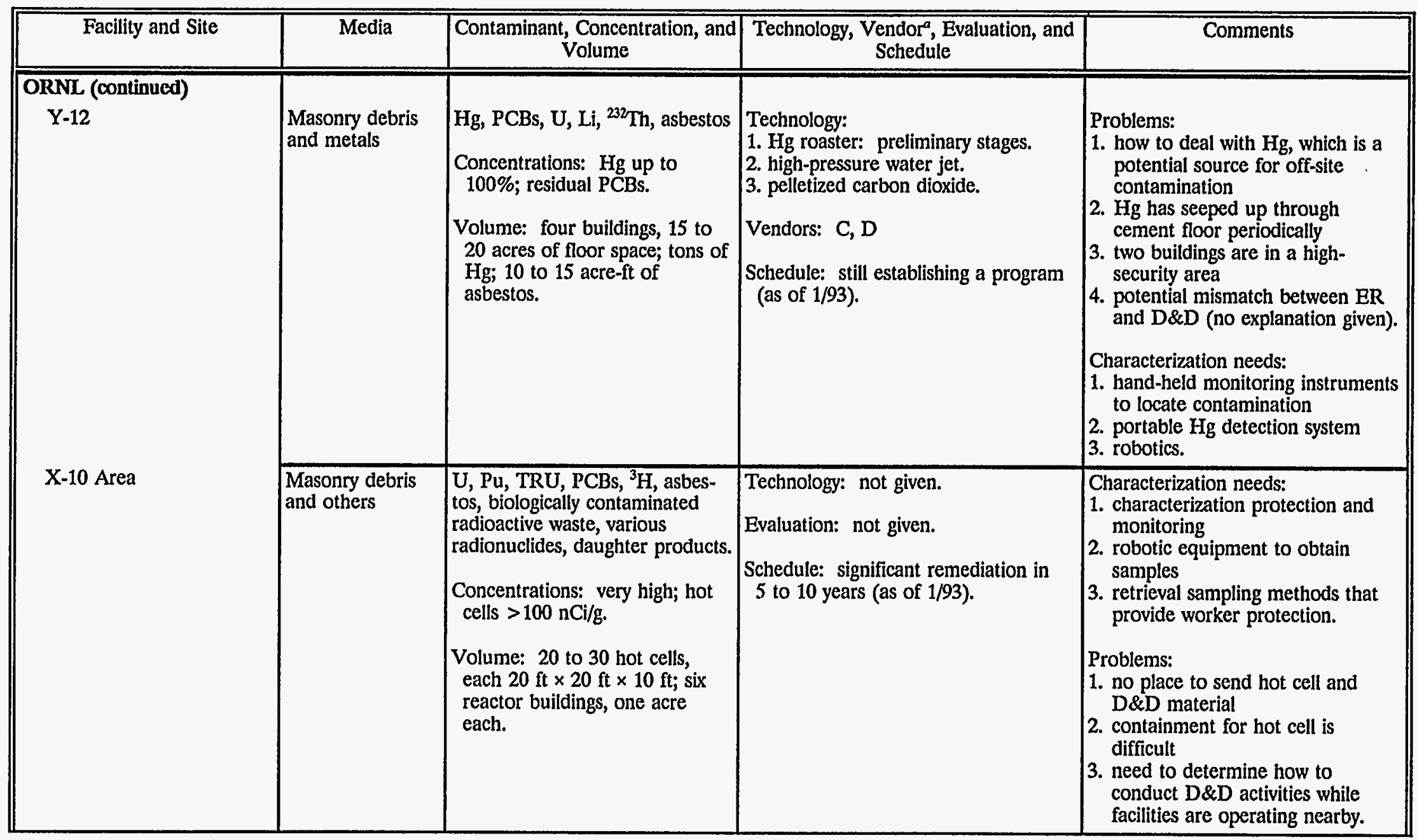


Table B.3. (continued)

\begin{tabular}{|c|c|c|c|c|}
\hline Facility and Site & Media & $\begin{array}{c}\text { Contaminant, Concentration, and } \\
\text { Volume }\end{array}$ & $\begin{array}{l}\text { Technology, Vendor }{ }^{a} \text {, Evaluation, and } \\
\text { Schedule }\end{array}$ & Comments \\
\hline \multicolumn{5}{|l|}{ ORNL (continued) } \\
\hline $\begin{array}{l}\text { Buried Material at } \\
\mathrm{Y}-12^{\mathbf{b}}\end{array}$ & $\begin{array}{l}\text { Buried material } \\
\text { (not specified) }\end{array}$ & $\begin{array}{l}\mathrm{PCBs}, \mathrm{U}, \mathrm{Hg}, \mathrm{Pb}, \mathrm{Cr}, \mathrm{Cd},{ }^{232} \mathrm{Th} \\
\text { pyrophoric U, chlorinated sol- } \\
\text { vents, creosote, heavy metals. } \\
\text { Concentrations: unknown. } \\
\text { Volume: unknown. }\end{array}$ & $\begin{array}{l}\text { Technology: not given. } \\
\text { Evaluation: not given. } \\
\text { Schedule: characterization and assess- } \\
\text { ment should be finished in } 1998 .\end{array}$ & $\begin{array}{l}\text { This covers buried material at the } \\
\text { Y-12 plant, Bear Creek Valley, and } \\
\text { Chestnut Ridge south of the Y-12 } \\
\text { plant. Approximately } 40 \text { acres of } \\
\text { buried wastes are capped at the } \\
\text { burial grounds at Chestnut Ridge; } \\
\text { RCRA caps are now undergoing } \\
\text { maintenance evaluation (as of 1/93). } \\
\text { A Federal Facilities Agreement has } \\
\text { been signed. } \\
\text { Characterization needs: } \\
\text { 1. analysis of leach rates from large- } \\
\text { scale lysimeters } \\
\text { 2. non-intrusive way (e.g., geophysi- } \\
\text { cal techniques) to define burial } \\
\text { grounds } \\
\text { 3. drawings and plans of sites, } \\
\text { background information on the } \\
\text { sites before drilling. } \\
\text { Problems: } \\
\text { 1. uncertainty about how to unearth } \\
\text { mixtures of pyrophoric materials } \\
\text { 2. the subsurface environment is } \\
\text { partly limestone and has many } \\
\text { cavities and water conduits } \\
\text { 3. uncertainty about what to do with } \\
\text { mixed-waste material. }\end{array}$ \\
\hline
\end{tabular}


Table B.3. (continued)

\begin{tabular}{|c|c|c|c|c|}
\hline Facility and Site & Media & $\begin{array}{c}\text { Contaminant, Concentration, and } \\
\text { Volume }\end{array}$ & $\begin{array}{c}\text { Technology, Vendor , Evaluation, and } \\
\text { Schedule }\end{array}$ & Comments \\
\hline \multicolumn{5}{|l|}{ Savannah River } \\
\hline Burial Ground Complex & $\begin{array}{l}\text { Buried material } \\
\text { (not specified) }\end{array}$ & $\begin{array}{l}\mathrm{Hg},{ }^{14} \mathrm{C} \text { on resin, TRU, organic } \\
\text { compounds, } \mathrm{LWW}, \mathrm{Ag}, \mathrm{Pb}, \mathrm{Cd}, \\
\text { waste oil, solvent rags, buried } \\
\text { solvent tanks, }{ }^{3} \mathrm{H} \text { in crucibles. } \\
\text { Concentrations: total activity of } \\
\text { radionuclides is } 1.9 \times 10^{7} \mathrm{Ci} \text {, no } \\
\text { information on other contami- } \\
\text { nants. } \\
\text { Volume: } 175 \text { acres, } 10 \text { to } 20 \mathrm{ft} \\
\text { deep. }\end{array}$ & $\begin{array}{l}\text { Technology and evaluation: } \\
\text { 1. capping of trenches: potential } \\
\text { problems with cap integrity, } \\
\text { maintenance, stability, and longevity } \\
\text { 2. grout in place: questionable long- } \\
\text { term effectiveness } \\
\text { 3. retrieval of TRU and disposal at } \\
\text { WrPP: costly } \\
\text { 4. immobilization: large area of } \\
\text { tritium plume makes it costly. } \\
\text { Schedule: in characterization (1/93); } \\
\text { closure plan due late FY93. All } \\
\text { demonstrations are being prepared } \\
\text { (1/93). RCRA post-closure permit } \\
\text { application due in November 1992. }\end{array}$ & $\begin{array}{l}\text { Facility composed of old, new, and } \\
\text { mixed-waste burial grounds. } \\
\text { Inventory records are not good for } \\
\text { old burial grounds but are fairly } \\
\text { complete for the other two; records } \\
\text { identify what is buried, though not } \\
\text { exactly where. Burial grounds are } \\
\text { source of groundwater contamina- } \\
\text { tion. TR w waste in old burial } \\
\text { grounds must be retrieved for ship- } \\
\text { ment to WPP. This is one of the } \\
\text { highest-priority units. }\end{array}$ \\
\hline D\&D activities & $\begin{array}{l}\text { Masonry debris } \\
\text { and others }\end{array}$ & $\begin{array}{l}\text { FLW, LLW, TRU, asbestos, } \\
\text { PCBs, freon, ethylene glycol, } \mathrm{Hg} \text {, } \\
\text { Pb, lube oil, gasoline, fuel oll, } \\
\text { mixed wastes (contaminated } \\
\text { asbestos). } \\
\text { Concentrations: up to very high. } \\
\text { Volume: very large } \\
\text { (657 facilities). }\end{array}$ & $\begin{array}{l}\text { Technology and evaluation: } \\
\text { 1. nitric acid electropolishing: } \\
\text { compatible with waste streams } \\
\text { 2. foam and } \mathrm{CO}_{2} \text { decontamination is } \\
\text { being evaluated to minimize } \\
\text { secondary waste } \\
\text { 3. abrasion with grit used in } \\
\text { glassification: would generate less } \\
\text { secondary waste, though possibly } \\
\text { unacceptable. } \\
\text { Vendors: D, B } \\
\text { Schedule: none. }\end{array}$ & $\begin{array}{l}\text { D\&D can be conducted with current } \\
\text { technologies, though these need } \\
\text { improvement to make work go } \\
\text { faster and generate less secondary } \\
\text { waste. } \\
\text { Problems: } \\
\text { 1. lack of funding } \\
\text { 2. lack of experienced people } \\
\text { 3. reactor D\&D required, as well } \\
\text { as hot cells and hot canyon } \\
\text { buildings, tanks, piping, metal } \\
\text { debris, process sludges from } \\
\text { D\&D operations } \\
\text { 4. extensive paperwork requirements } \\
\text { 5. conflicting regulatory } \\
\text { requirements } \\
\text { 6. need to declassify materials before } \\
\text { they can undergo D\&D } \\
\text { 7. lack of a focused D\&D program. } \\
\text { Characterization needs: } \\
\text { 1. better methods for sampling and } \\
\text { analysis of HLW that are lower in } \\
\text { cost and generate lower quantities } \\
\text { of secondary waste } \\
\text { 2. remote evaluation of containment } \\
\text { vessels and reactors. }\end{array}$ \\
\hline
\end{tabular}


Table B.3. (continued)

\begin{tabular}{|c|c|c|c|c|}
\hline Facility and Site & Media & $\begin{array}{c}\text { Contaminant, Concentration, and } \\
\text { Volume }\end{array}$ & $\begin{array}{c}\text { Technology, Vendor }{ }^{\curvearrowleft}, \text { Evaluation, and } \\
\text { Schedule }\end{array}$ & Comments \\
\hline $\begin{array}{l}\text { Weldon Spring Site Remedial } \\
\text { Action Project } \\
\text { RAP buildings }\end{array}$ & $\begin{array}{l}\text { Masonry debris } \\
\text { and metal }\end{array}$ & $\begin{array}{l}\mathrm{U},{ }^{230} \mathrm{Th},{ }^{232} \mathrm{Th},{ }^{226} \mathrm{Ra},{ }^{228} \mathrm{Ra} \text {. } \\
\text { Concentrations: up to } \\
100,000 \mathrm{dpm} \text { alpha/100 } \mathrm{cm}^{2} \text {. } \\
\text { Volume: } 60,000 \mathrm{yd}^{3} \text { (all types of } \\
\text { debris). }\end{array}$ & $\begin{array}{l}\text { Technology: not given; decontamina- } \\
\text { tion and survey for free release. } \\
\text { Evaluation: expensive. } \\
\text { Schedule: not given. }\end{array}$ & $\begin{array}{l}\text { Information was obtained from the } \\
\text { completed wSR guidance docu- } \\
\text { ment; interviews were not held with } \\
\text { site personnel. } \\
\text { Decontamination of metal for free } \\
\text { release is prohibitively expensive due } \\
\text { mainly to labor-intensive radiation } \\
\text { scans for free release. } \\
\text { Buildings to be demolished; cost of } \\
\text { decontamination and radiological } \\
\text { surveying overwhelming when added } \\
\text { to disposal of all metal and debris. }\end{array}$ \\
\hline RAP buildings/soils & $\begin{array}{l}\text { Masonry debris } \\
\text { and soil }\end{array}$ & $\begin{array}{l}\text { Uranium: up to } 50,000 \mathrm{pCi} / \mathrm{g} ; \\
\text { total inventory } 7 \mathrm{Ci} \text {. } \\
\text { Volume: soil } 300,000 \mathrm{yd}^{3} \text {; debris } \\
60,000 \mathrm{yd}^{3} \text {. }\end{array}$ & $\begin{array}{l}\text { Technology and evaluation: } \\
\text { 1. decontamination and on-site } \\
\text { disposal: expensive } \\
\text { 2. soil excavation } \\
\text { 3. soil stabilization } \\
\text { 4. vitrification. } \\
\text { Schedule: not given. }\end{array}$ & $\begin{array}{l}\text { Information was obtained from the } \\
\text { completed WSR guidance docu- } \\
\text { ment; interviews were not held with } \\
\text { site personnel. The guidance states } \\
\text { that this problem is the lowest } \\
\text { priority and that it accounts for } 10 \% \\
\text { of the total facility problems. } \\
\text { Characterization needs: data on } \\
\text { soil permeability in the unsaturated } \\
\text { zone. This would aid in defining } \\
\text { transport/retardation mechanisms. }\end{array}$ \\
\hline
\end{tabular}

a See Table B.4

b This table was compiled from results of a search in CROSSWALK, a data base published by RUST Geotech, Inc., for the U.S. DOE Office of Environmental Restoration, January 1993. In the search, "concrete" and "masonry" were linked to "decontamination" as key words. Consequently, site names and information obtained from the data base should be relevant in some way to concrete and masonry decontamination. However, several reports do not contain the key words and instead describe landfills, sludge ponds, soil, and other media. These sites may not have a direct application to concrete decontamination.

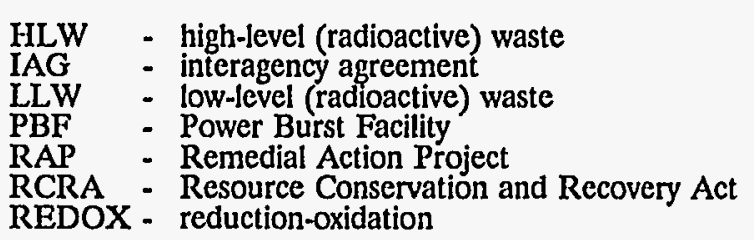


Table B.4. Vendors of concrete decontamination technologies as identified in the CROSSWALK data base

\begin{tabular}{|c|c|c|}
\hline Vendor Code & Technology Name & Vendor \\
\hline A & Chemical treatment & $\begin{array}{l}\text { Rust Remedial Services, Clemson Technical Center, } \\
100 \text { Technology Drive, Clemson Research Park, Anderson, SC } 29625 \\
\text { Molten Metal Technology, Inc., } 51 \text { Sawyer Road, Waltham, MA } 92154 \\
\text { hydroGEOPHYSICS, } 5865 \text { S. Old Spanish Trail, Tucson, AZ } 85747\end{array}$ \\
\hline B & Abrasion & Container Products Corporation, P.O. Box 3767, Wilmington, NC 28406 \\
\hline $\mathrm{C}$ & High-pressure hot water & $\begin{array}{l}\text { Flow International, Environmental Application Division, } \\
2144068 \text { th Avenue South, Kent, WA } 98032 \\
\text { Container Products Corporation, P.O. Box } 3767 \text {, Wilmington, NC } 28406\end{array}$ \\
\hline $\mathrm{D}$ & $\begin{array}{l}\text { Cryogenesis, cleaning with dry ice, } \\
\mathrm{CO}_{2} \text { pellet gas }\end{array}$ & $\begin{array}{l}\text { Va-Tran Systems, Inc., } \\
677 \text { Anita Street, Suite A, Chula Vista, CA } 91911 \\
\text { Waste Minimization and Containment Corporation, } \\
2140 \text { Scranton Road, Cleveland, OH } 44113 \\
\end{array}$ \\
\hline $\mathrm{E}$ & Scabbling and scarification & $\begin{array}{l}\text { Quest, Integrated, Inc., Technology Division, } \\
2141468 \text { th Avenue South, Kent, WA } 98030 \\
\text { JVI Environmental, Inc., } 1343 \text { South Schmuhl Road, New Lenox, IL } 60451 \\
\text { Pentek, Inc., } 1026 \text { Fourth Avenue, Coraopolis, PA } 15108\end{array}$ \\
\hline F & $\begin{array}{l}\text { High resolution fiber optic } \\
\text { interferometer (monitoring and } \\
\text { sensing technology) }\end{array}$ & Ames Laboratory/Iowa State University \\
\hline
\end{tabular}


APPENDIX C

TECHNOLOGY DESCRIPTION FACT SHEETS 
-

•

。

.

, 


\section{Accelerated Testing of Concrete Decontamination Methods Technology Description Fact Sheet}

1. Technology name: Biological decontamination (microbially influenced degradation).

\section{Technology type: Biological}

3. Process description: This entails the enhancement of a naturally occurring microbiological process that uses microorganisms (thiobacilli) that are know to be responsible for the microbially influenced degradation of concrete. These microorganisms produce mineral acids that dissolve or disintegrate the concrete matrix. The process is currently in the experimental and development stage. The field-scale process is envisioned to involve several steps. Organisms will be introduced to form a uniform covering of the surface, probably through a spray or fine mist over the structure surface. Conditions to promote bacterial activity will be established: a simple enclosure and periodic spray of mineral salts and water solution to supply nutrients (sulfur) and moisture. After an extended period of time (several months to several years depending on rate of biodegradation and depth of contamination) spraying will be terminated and the surface will be allowed to dry, thereby ending the activity of the bacteria. The surface "rubble" that has been loosened by the bacterial activity will be removed either by brushing or vacuuming.

4. Potential vendors, contact, and phone: Melinda Hamilton (208) 526-0948 and Robert Rogers (208) 526-0685, INEL technology developers. CRADA in place with British Nuclear Fuels, Dr. Robert Holmes, 0772762000.

5. Level of cleanup: All contaminants within the layer of concrete removed (i.e., $100 \%$ removal).

6. Processing rates: It is anticipated that through control of the environment to optimize biological activity, rates of surface removal as high as $10 \mathrm{~mm} / \mathrm{year}$ may be achieved. The process is expected to remove surface contaminants in periods of several months to several years depending on the depth of contamination and site conditions. The time necessary would therefore be site-specific. The process slow compared to physical methods (scabbling, etc.); however, efficiency is expected to be greater for biological decontamination since a uniform removal of the entire surface can be achieved. Biocorrosion of concrete in nature has been observed at rates as high as $4.6 \mathrm{~mm} / \mathrm{year}$. A recent inspection of a massive concrete structure $\left(20,000 \mathrm{~m}^{2}\right)$ demonstrated uniform surface removal by bacterial degradation of 2 to $4 \mathrm{~mm}$ and up to 2 to $3 \mathrm{~cm}$ in some areas over a period of 4 years. 


\section{C-2}

7. Contaminants removed: Heavy metals, radionuclides (including TRU). Thiobacilli are often inhibited by the presence of abundant organic compounds; therefore, the process is not expected to be applicable to organic contaminants. Specific applications for the process will be examined in a field demonstration planned FY96.

8. Waste volume(s) and type: Waste volumes per area processed have not been determined, but, as with other surface removal processes, are dependent on the depth of contamination. Waste volume should be significantly reduced, including only the spalled concrete. The waste type consists of a dry "rubble" from the spalled concrete material and the commingled dead biomass and contaminants. No secondary waste stream is anticipated.

9. Process applicability/flexibility: The process is specifically designed for concrete surfaces and is expected to work best on uncoated concrete surfaces, although other applications such as epoxy coated surfaces will be evaluated in field demonstrations. Because the micoorganisms are naturally occurring, the process is expected to be robust and minimally effected by minor changes in nutrients and moisture availability.

10. Estimated cost: Estimated cost per unit area of contaminated concrete is approximately $\$ 2$ to $3 / \mathrm{At}^{2}$.

11. Stage of development: Experimental/developmental. Lab studies are ongoing to further demonstrate and optimize the process while also developing the process for field application.

12. Approximate number of full-scale projects: None.

13. Equipment availability: Expected development of equipment for field application is 1 to 2 years.

14. Unusual potential environmental and/or safety risks: None. Risks are reduced compared to conventional technologies because man-entry and cross-contamination are reduced.

\section{Other:}




\section{Accelerated Testing of Concrete Decontamination Methods Technology Description Fact Sheet}

1. Technology name: Carbon Dioxide $\left(\mathrm{CO}_{2}\right)$ Blasting

-2. Technology type: Physical/mechanical, non-destructive

3. Process description: $\mathrm{CO}_{2}$ blasting is a surface cleaning process in which compressed air delivers $\mathrm{CO}_{2}$ ice crystals under pressure, impacting contaminated surfaces at high velocities. The $\mathrm{CO}_{2}$ abrasive crystals remove contaminants and surficial coatings, but because the crystals are softer than the concrete, it does not degrade the surface. Advantages of the process are that it is a non-destructive process, produces no secondary waste, provides waste volume minimization, and can clean delicate material. However, based on the experience of the K-25 decontamination group for cleaning concrete surfaces, the process is slow, hàs difficultly removing contaminants to the specified levels, has operational problems, and is expensive.

4. Potential vendors, contact, and phone: Non-Destructive Testing, Pat Gillis, (508) 660-3064; CyroDynamics, Chris Wetherall, (615) 376-4183

5. Level of cleanup: All surface contaminants.

6. Processing rates: 90 to $180 \mathrm{ft}^{2} / \mathrm{h}, \mathrm{K}-25$ experience closer to 10 to $20 \mathrm{ft}^{2} / \mathrm{h}$.

7. Contaminants removed: All

8. Waste volume(s) and type: Waste is collected by vacuum onto a filter cartridge. Actual volumes of waste are dependant on the application and the efficiency of the filters.

9. Process applicability/flexibility: All shapes down to small pieces. There is a limitation of $150 \mathrm{ft}$ from the operating unit. Therefore, the unit must be moved if the treatment area exceeds $150 \mathrm{ft}$, which is a significant task because of multiple large pieces of equipment.

10. Estimated cost: $\$ 0.90$ to $1.75 / \mathrm{ft}^{2}$.

11. Stage of development: Commercial.

12. Approximate number of full-scale projects: Non-Destructive Testing has over 120 months of operating experience and a fleet of seven mobile facilities for equipment rent or full service.

13. Equipment availability: Immediate. 


\section{C-4}

14. Unusual potential environmental and/or safety risks: $\mathrm{CO}_{2}$ in a confined area.

15. Other: Metal cleaning at Hanford and MNEL. Concrete testing at K-25. Opinion of $\mathrm{K}-25$ decontamination group was that $\mathrm{CO}_{2}$ is not very effective for concrete decontamination, is slow and awkward, creates significant waste in the form of filters, and is expensive. 


\section{Accelerated Testing of Concrete Decontamination Methods Technology Description Fact Sheet}

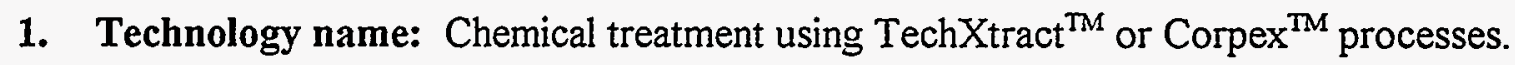

2. Technology type: Chemical, non-destructive

3. Process description: These processes use chemical treatment for extraction of radionuclides, heavy metals, PCBs, and hazardous organics from concrete and sequential chemical extraction to remove the contaminants. The TechXtract ${ }^{\mathrm{TM}}$ process claims 90 to $99 \%$ extraction up to 1 to 3 in. below the surface. The Corpex ${ }^{\mathrm{TM}}$ process dissolves a finite layer of concrete along with the contaminants and claim surface removal only. Multiple applications produce improved removal efficiency. Both processes are temperature sensitive, but the advantages of chemical treatment is that it is nondestructive and can be easily applied to rubble. The process is also non-dusting.

4. Potential vendors, contact, and phone: EET Inc., (713) 662-2322, Mike Bonem for TechXtract $^{\mathrm{TM}}$; Corpex Technologies, (919) 941-0847, Vance Syphers. These are the only vendors claiming radionuclide treatment. There are many other vendors for nonradioactive applications.

5. Level of cleanup: Claims up to $99 \%$ removal all contaminants, surface to 3 in.

6. Processing rates: Up to $100 \mathrm{ft}^{2} /$ man-hours.

7. Contaminants removed: Have treated for all the elements on the periodic table with various degrees of success depending on the type of concrete, temperature, contaminant, and concentration.

8. Waste volume(s) and type: 30 to 60 gal of liquid/1,000 $\mathrm{ft}^{2}$ processed (EET) and a slurry type waste for Corpex. No estimate of volume for Corpex.

9. Process applicability/flexibility: Can be applied to all shapes and forms of concrete.

10. Estimated cost: EET: $\$ 4$ to $\$ 50 / \mathrm{ft}^{2}$; service by licensed applicators.

11. Stage of development: Commercial for non-radiological applications. In development process for radiological applications.

12. Approximate number of full-scale projects: Six radiological projects and over 200 non-radiological applications for EET. Two radiological projects and multiple other applications for Corpex. 
13. Equipment availability: Immediate

14. Unusual potential environmental and/or safety risks: None specifically identified; however, during the EET process application, the solution has a $\mathrm{pH}$ of $<2$.

15. Other: EET has conducted demonstrations for removal of radiation from concrete at HANF, PORTS, LANL, and INEL, and a full-scale application is on-going at Mound for $\mathrm{Pu}$ removal from a concrete floor. Also, a radiological metal decontamination at $\mathrm{K}-25$ was conducted. No applications for Corpex within DOE. Observations of the PORTS demonstration (by $\mathrm{K}-25$ personnel) conducted by EET were that it was no more effective than using a standard 409 type detergent, there was a significant odor, and they were using proprietary chemicals of unknown origin. 


\section{C-7 \\ Accelerated Testing of Concrete Decontamination Methods \\ Technology Description Fact Sheet}

1. Technology name: Chromographic strippable coatings (Sensor Coat)

2. Technology type: Chemical

3. Process description: Sensing strippable coatings are water-based, non-toxic polymer systems that form strong films that are easily peeled from a variety of surfaces. Sensing strippable coatings display extreme color changes when used to coat a contaminated surface, indicating the areas where contamination is present. When applied over a contaminated surface, a sensing strippable coating attracts and binds the contaminant. After drying, removal of the film decontaminates the surface.

4. Potential vendors, contact, and phone: Betty Jorgensen (505) 667-3619, LANL technology developer.

5. Level of cleanup: Laboratory tests have achieved up to $100 \%$ removal of uranium (painted aluminum surface) and up to $97 \%$ removal of plutonium.

6. Processing rates: Similar to commercially available strippable coatings. Sensing strippable coatings require 3 to $24 \mathrm{~h}$ to dry depending on humidity and film thickness.

7. Contaminants removed: Uranium, plutonium, lead. Plans are in progress to develop a series of coatings that will be effective for a variety of conditions and contaminants.

8. Waste volume(s) and type: Waste volumes per area processed have not been determined. The waste type consists of the film removed from the surface.

9. Process applicability/flexibility: The process is recommended for decontamination of heavy metal isotopes from the surfaces of floors, walls, glove boxes, and equipment.

10. Estimated cost: Unknown.

11. Stage of development: Experimental/developmental. Lab studies are ongoing to further demonstrate and optimize the process.

12. Approximate number of full-scale projects: None 
13. Equipment availability: Unknown.

14. Unusual potential environmental and/or safety risks: None.

15. Other: 


\section{Accelerated Testing of Concrete Decontamination Methods Technology Description Fact Sheet}

1. Technology name: Electro-Hydraulic Scabbling

2. Technology type: Physical/mechanical, destructive surface removal

3. Process description: The electro-hydraulic scabbling process is a wet technique that involves the generation of powerful shock waves and intense cavitation by a strongpulsed electric discharge in a water layer at the concrete surface. High-impulse pressure results in stresses that crack and peel off a concrete layer of a controllable thickness. The amount of electric current supplied to the arcing tool determines both the rate of processing and depth of treatment. Potential advantages of the process are fewer airborne particulates and dust and less water than conventionally pressured water treatment systems.

4. Potential vendors, contact, and phone: Textron Defense Systems, Dick Gannon, (617) 381-4630. Pentek is designing the auxiliary systems (HEPA vacuum and controls) and will be offering operating service contracts using this equipment.

5. Level of cleanup: Potential for up to 1 in.-depth, independent of contaminants

6. Processing rates: Current machine has only a single electrode. Prototype will have four electrodes and is projected to be able to process at approximately 20 to $40 \mathrm{ft}^{2} / \mathrm{h}$.

7. Contaminants removed: All within the layer of concrete removed.

8. Waste volume(s) and type: Volumes per area processed have still not been determined. A system is being designed that would recycle water and produce 500 to 1000 gal per $1,000 \mathrm{ft}^{2}$ of processed material. Waste will be a liquid and solid mixture or sludge.

9. Process applicability/flexibility: Initial design will be for floors only; should be applicable for remote or robotics control.

10. Estimated cost: Initial estimated cost is $\$ 0.65$ to $\$ 1.85 / \mathrm{ft}^{2}$.

11. Stage of development: Developmental; prototype is being designed by Pentek.

12. Approximate number of full-scale projects: None 
C-10

13. Equipment availability: Prototype should be available for demonstration within the next 2 to 4 months

14. Unusual potential environmental and/or safety risks: None determined.

15. Other: A demonstration will be held at FEMP. 


\section{Accelerated Testing of Concrete Decontamination Methods Technology Description Fact Sheet}

\section{Technology name: Electrokinetic}

2. Technology type: Electrical/chemical/physical, non-destructive

3. Process description: A polymer-encased or other type surface electrode is placed on the surface of the concrete along with a solution of solubilizing complexants. A counter electrode is put into the surface of the concrete, and an electric force is applied to the electrodes, which drives the solubilizing complexants into the concrete and mobilizes the various metals, radionuclides, and/or organic contaminants. The current is then reversed, and the solubilized contaminants are driven to the surface and collected. Advantages of the process are removal of contaminants only, expected waste volume reduction, lower worker exposure, and in situ applications.

4. Potential vendors, contact, and phone: ISOTRON, Richard Graves, (504) 254-4624

5. Level of cleanup: Not yet determined; one test showed 65 to $70 \%$ removal of certain contaminants.

6. Processing rates: Not yet determined; rates are dependant on current flux and level and depth of contaminants.

7. Contaminants removed: All contaminants that can be solubilized in the extractant at the depth the extractant can be driven into the concrete.

8. Waste volume(s) and type: Not yet determined.

9. Process applicability/flexibility: Currently technology only applicable for floors.

10. Estimated cost: Not yet determined.

11. Stage of development: Bench/pilot scale.

12. Approximate number of full-scale projects: Not yet commercial for concrete decontamination.

13. Equipment availability: Not applicable. 
14. Unusual potential environmental and/or safety risks: None

15. Other: A demonstration for concrete decontamination using the ISOTRON process was conducted at $\mathrm{K}-25$, and the results were non-conclusive (post-characterization was not performed due to lack of funding). Another demonstration is scheduled for March 1995 at $\mathrm{K}-25$. 


\section{Accelerated Testing of Concrete Decontamination Methods \\ Technology Description Fact Sheet}

1. Technology name: Flash Lamp Starboldt*

2. Technology type: Electrical/thermal, non-destructive

3. Process description: The flash lamp process operates by pulsing an electric current to a zenon-filled quartz lamp, similar to a photographic camera flash. The zenon gas absorbs and subsequently releases the energy as photons, emitting brilliant flashes. With the aid of the reflector housed in the hand-held application head, the emitted light is concentrated and projected onto the coated surface. The coating absorbs the light energy and is ablated from the surface. While the surface is being de-painted, the process by-product of fine ash and gases is vacuumed into a containment drum and fume scrubber through a vacuum line in the application head. The vendor is concentrating on marketing the process for paint stripping for bridges, overpasses, etc.

4. Potential vendors, contact, and phone: Polygon Industries, Christa Chiacos, (415) 391-6063

5. Level of cleanup: All surface contaminants and coatings.

6. Processing rates: Up to $120 \mathrm{ft}^{2} / \mathrm{h}$.

7. Contaminants removed: All on surface of concrete.

8. Waste volume(s) and type: Ash from coating burn; volume depends on application.

9. Process applicability/flexibility: Expected to handle all shapes and surfaces.

10. Estimated cost: Not available

11. Stage of development: A prototype system is available for decontamination, although it has not really been tested.

12. Approximate number of full-scale projects: None for concrete decontamination.

13. Equipment availability: Immediate

14. Unusual potential environmental and/or safety risks: None

15. Other: Did a short demonstration at DOE Ashtabula, Ohio for concrete decontamination. 


\section{Accelerated Testing of Concrete Decontamination Methods Technology Description Fact Sheet}

1. Technology name: Ice Blasting

2. Technology type: Physical/Mechanical, Non-Destructive

3. Process description: Ice blasting is a surface cleaning process in which compressed air delivers ice crystals under pressure, and impacts contaminated surfaces at high velocities. The abrasive ice crystals remove contaminants and surficial coatings, but, because the crystals are softer than the concrete, it does not degrade the surface. Advantages of the process are that it is a non-destructive process, waste volume minimization by filtration and liquid recycle, and it can clean delicate material.

4. Potential vendors, contact, and phone: ARC, Ted Martucci, (800) 241-6575.

5. Level of cleanup: All surface contaminants.

6. Processing rates: Application dependent (concrete density, surface coating, fixed or loose contamination, etc.).

7. Range of contaminants removed: All surface contamination loose and fixed.

8. Waste volume(s) and type: 8 to $10 \mathrm{gal} / \mathrm{h}$ of liquid, independent of processing rate.

9. Process applicability/flexibility: All shapes and forms for all surfaces.

10. Estimated cost: Capital cost $\$ 170 \mathrm{~K}$, as a service $\$ 175 / \mathrm{h}$ independent of processing rate.

11. Stage of development: Commercial.

12. Approximate number of full-scale projects: Many for various applications. Approximately 20 radioactive concrete decontamination.

13. Equipment availability: Immediate.

14. Unusual potential environmental and/or safety risks: None.

15. Other: 


\section{Accelerated Testing of Concrete Decontamination Methods \\ Technology Description Fact Sheet}

\section{Technology name: Laser Ablation}

2. Technology type: Electrical/thermal, non-destructive

3. Process description: Laser ablation is a fast, high-intensity heating that breaks coatings and contaminants from the surface. This system uses a $\mathrm{CO}_{2}$ laser along with the right combination of wavelength, pulse width, energy and power densities on target, pulse repetition rate, and scan rate that will yield efficient removal of coating material from the surface and surface pores, resulting in material ablation faster than a thermal wave and leaving a cool surface behind. A gas/vapor and particulate suction nozzle captures and contains the ablated material. This is combined with other processes that result in material bulk reduction. A vacuum pump draws the mixture of entrained air and gases, vapors, and particulates from ablation through filtering stages. Advantages claimed are: ablation, volume reduction, and capture of contaminants in a one-step process; cleaning out of surface pores as well as cleaning off surface coatings; and reduced worker exposure.

4. Potential vendors, contact, and phone: F2 Associates, Joyce Frelwald, (505) 271-0260

5. Level of cleanup: Not yet fully characterized; expected to handle all surface contaminants.

6. Processing rates: Projecting up to $85 \mathrm{ft}^{2} / \mathrm{h}$ for up to $3 / 8$-in. coatings; not yet demonstrated.

7. Contaminants removed: All on surface and surface pores of the concrete.

8. Waste volume(s) and type: Not yet determined; projecting a $75 \%$ volume reduction of the coating material removed.

9. Process applicability/flexibility: Expected to handle all shapes of surfaces.

10. Estimated cost: Not yet determined.

11. Stage of development: Lab scale; currently building a full-scale prototype.

12. Approximate number of full-scale projects: None 
13. Equipment availability: Building full-scale prototype, available 1/96

14. Unusual potential environmental and/or safety risks: None identified.

15. Other: Vendor has a contract with DOE Morgantown Energy Technology Center (METC) for development of the system. Vendor has completed the first stage: to build and test a low-powered bench-scale lab unit. Phase 2, now in progress, is to build and test a full-powered, full-scale prototype. 


\section{C-17}

\section{Accelerated Testing of Concrete Decontamination Methods Technology Description Fact Sheet}

1. Technology name: Microwave

2. Technology type: Electrical/thermal/physical, destructive surface removal

3. Process description: The microwave concrete decontamination process is a very aggressive process that rapidly heats the near surface of the concrete, creates steam explosions from the moisture in the concrete, causes surface destruction, and breaks the concrete into chunks. These chunks are typically 10 times larger than those created by mechanical scabbling equipment. Significantly less airborne material is the benefit. The chunks and contamination are collected by a HEPA vacuum system into a 15 -gal waste container.

4. Potential vendors, contact, and phone: ORNL, Terry White, (615) 574-0983

5. Level of cleanup: Up to 2 in. per pass independent of contaminants.

6. Processing rates: $40 \mathrm{ft}^{2} / \mathrm{h}$ at $5-\mathrm{mm}$ surface removal.

7. Contaminants removed: All within the layer of concrete removed.

8. Waste volume(s) and type: $150 \mathrm{ft}^{3} / 1000 \mathrm{ft}^{2}$ processed at $5-\mathrm{mm}$ removal depth of concrete.

9. Process applicability/flexibility: Horizontal, vertical, and overhead surfaces.

10. Estimated cost: $\$ 2.00 / \mathrm{ft}^{2}$ operating; capital cost of equipment is $\$ 150,000$.

11. Stage of development: Full-scale prototype.

12. Approximate number of full-scale projects: None

13. Equipment availability: Immediate

14. Unusual potential environmental and/or safety risks: Nothing unusual

15. Other: Technology is not available in the private sector. System has been tested only on surrogate wastes. 


\section{Accelerated Testing of Concrete Decontamination Methods Technology Description Fact Sheet}

1. Technology name: Multi-Unit Operation Scarification: High Performance Vac-Pac ${ }^{\circledR}$ Squirrel $^{\circledR}$ III Floor Scabbler \& Corner Cutter ${ }^{\circledR}$ Needle Gun System

2. Technology type: Physical/mechanical, destructive surface removal .

3. Process description: This system integrates several pieces of the family of scabbling equipment and emission control to handle all configurations of concrete that are encountered in the work place, such as walls, floors, ceilings, and stairs. The principles of operation for the High Performance Vac-Pac Squirrel ${ }^{\text {(I) }}$ III Floor Scabbler, along with the Corner Cutter ${ }^{\otimes}$ needle gun, which is applied where the contamination is in hard to reach places, are described in the process description of the Moose ${ }^{\otimes}$. The needle gun uses needles to remove the concrete and contaminants; production rates are slow.

4. Potential vendors, contact, and phone: PENTEK Inc., Eric Crivelia, (412) 262-0725

5. Level of cleanup: 1/16-in. per pass, independent of contaminants.

6. Processing rates: 20 to $30 \mathrm{ft}^{2} / \mathrm{h}$ at $1 / 16$-in. surface removal.

7. Contaminants removed: All within layer of concrete removed.

8. Waste volume(s) and type: $78 \mathrm{gal}$ of dry waste/1,000 $\mathrm{ft}^{2}$ processed at $1 / 16$-in. removal depth of concrete. If just using the needle gun, the waste volume is reduced to $30 \mathrm{gal}$ of dry waste $/ 1,000 \mathrm{ft}^{2}$ processed.

9. Process applicability/flexibility: Can handle all shapes and forms except small rubble; also applicable to remote or robotics control.

10. Estimated cost: Service contract operating cost is $\$ 1.85$ to $\$ 2.50 / \mathrm{ft}^{2}$, depending on the specific geometry of the concrete and, therefore, which piece of equipment must be used (system purchase price is $\$ 48 \mathrm{~K}$ ).

11. Stage of development: Commercially available.

12. Approximate number of full-scale projects: Many; $>2 \times 10^{6} \mathrm{ft}^{2}$ processed. 


\section{C-19}

13. Equipment availability: Immediate.

14. Unusual potential environmental and/or safety risks: Noise is a potential problem. No other problems exist. Like the MOOSE ${ }^{\otimes}$, essentially $100 \%$ of airborne particulates and over $99.5 \%$ of heavier solids are captured at the cutting tool surface. The on-board, two-stage HEPA filtration system has an efficiency rating of $99.5 \%$ at $1-\mu$ first stage and $99.97 \%$ at $0.3-\mu$ second stage.

15. Other: Equipment has been demonstrated and operated at a third of the sites within the DOE system on numerous occasions. This equipment is used often at $\mathrm{K}-25$ at a production scale for concrete decontamination. 


\section{Accelerated Testing of Concrete Decontamination Methods Technology Description Fact Sheet}

1. Technology name: Scarification: MOOSE

2. Technology type: Physical/mechanical, destructive surface removal.

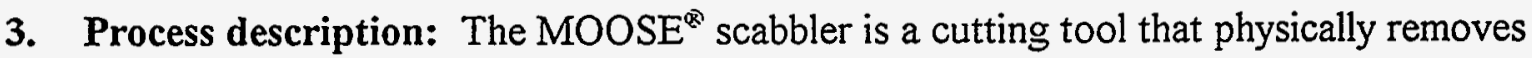
contaminants and a 1/16 to 3/16-in. layer of concrete per pass. This machine is used primarily for treating large floor areas. It is comprised of three integral sub-systems: the scabbling head assembly, an on-board HEPA vacuum system, and a six-wheeled chassis. The scabbling head uses seven reciprocating tungsten carbide-tipped bits. These bits pulverize the surface by 1200 hammer impacts per minute through pistons driven by compressed air. Dust and debris are collected by the high performance, two-stage HEPA vacuum system that deposits the waste into a 23 -gal on-board container. The sixwheeled chassis allows for easy control of the machine.

4. Potential vendors, contact, and phone: PENTEK Inc., Eric Crivelia, (412) 262-0725

5. Level of cleanup: $1 / 16$ in. per pass independent of contaminants.

6. Processing rates: 200 to $400 \mathrm{ft}^{2} / \mathrm{h}$ at $1 / 16$-in. surface removal.

7. Contaminants removed: All within layer of material removed.

8. Waste volume(s) and type: $78 \mathrm{gal}$ of dry waste/1,000 $\mathrm{ft}^{2}$ processed at $1 / 16$-in. removal depth of concrete.

9. Process applicability/flexibility: Floors only and clearance to within 6 in. of the wall; applicable to remote or robotics control.

10. Estimated cost: Service contract operating cost $\$ 1.85$ to $\$ 2.50 / \mathrm{ft}^{2}$ (machine purchase price is $\$ 155 \mathrm{~K}$ )

11. Stage of development: Commercially available since 1985.

12. Approximate number of full-scale projects: Multiple; $>750,000 \mathrm{ft}^{2}$ processed.

13. Equipment availability: Immediate. 
14. Unusual potential environmental and/or safety risks: Noise is a potential problem. No other problems exist because essentially $100 \%$ of airborne particulates and over $99.5 \%$ of heavier solids are captured at the cutting tool surface. The on-board two-stage HEPA filtration system has a rating of $99.5 \%$ at first stage and a $99.97 \%$ at $0.3-\mu$ second stage efficiency.

15. Other: Equipment has been demonstrated and operated at WVDP. 


\section{Accelerated Testing of Concrete Decontamination Methods Technology Description Fact Sheet}

1. Technology name: Shot Blasting

2. Technology type: Physical/mechanical, destructive surface removal

3. Process description: Steel shot is propelled at the surface using a blast wheel (center fed or paddle). The steel shot abrades the surface down to $1 / 4$ in. of concrete per pass. The blast area is covered by a blast hood and vacuum recycle system. The size of the blast hoods range from 2 to 16 in. The vacuum system recovers and separates the debris and shot. The shot is then recycled to minimize waste volume. Shot blasters come in many different sizes, depending on the application. The shot blast is a very effective, quiet process for surface preparation and decontamination.

4. Potential vendors, contact, and phone: Nalco Equipment, (800) 256-3440, Chris Nighbor

5. Level of cleanup: Up to $1 / 4$ in. per pass, independent of contaminants.

6. Processing rates: $30 \mathrm{ft}^{2}$ to $3,000 \mathrm{ft}^{2} / \mathrm{h}$, depending on machine and application.

7. Contaminants removed: All within layer of concrete removed.

8. Waste volume(s) and type: Wide variance based on type of concrete, machine, and application.

9. Process applicability/flexibility: Horizontal, vertical, and overhead surfaces.

10. Estimated cost: $\$ 0.04$ to $\$ 0.15 / \mathrm{ft}^{2}$ excluding disposal of waste.

11. Stage of development: Commercially available.

12. Approximate number of full-scale projects: Many; company has been in business 21 years

13. Equipment availability: Immediate

14. Unusual potential environmental and/or safety risks: None

15. Other: This equipment has been used extensively throughout the DOE complex for concrete decontamination. The K-25 decontamination group feels that the shot blaster is the most effective piece of equipment for decontamination of concrete. 


\section{Accelerated Testing of Concrete Decontamination Methods Technology Description Fact Sheet}

1. Technology name: Soda Blasting $\left(\mathrm{NaCO}_{3}\right)$

2. Technology type: Physical/mechanical, non-destructive contaminant removal and physical/chemical waste processing and volume reduction.

3. Process description: Soda blasting is a surface cleaning process in which compressed air delivers sodium bicarbonate, under pressure, that impacts contaminated surfaces at high velocities. The sodium bicarbonate abrasive crystals remove contaminants and surficial coatings, but because the crystals are softer than the concrete, does not degrade the surface. The surfaces are washed to remove blast residuals. The slurry is then collected by a wet or dry vacuum system. The slurry is treated by physical and chemical processes, including precipitation, filtration, chemical reduction, carbon absorption, and ion exchange. Major advantages are volume reduction and waste minimization and chemical processing for separation of RCRA waste and radioactive contaminants, minimizing mixed waste production. Due to the nature of the sodium bicarbonate, there will be some dusting of this material. A disadvantage is that it requires multiple-unit operations for waste processing.

4. Potential vendors, contact, and phone: OBG Technical Services, Eric Newbauer, (315) 437-6400

5. Level of cleanup: 95 to $99 \%$ removal of all surface contaminants.

6. Processing rates: Up to $120 \mathrm{ft}^{2} / \mathrm{h}$ depending on surface coatings and contaminants. $\mathrm{K}-25$ experience was much slower processing rates.

7. Contaminants removed: Any surface contaminants.

8. Waste volume(s) and type: $250 \mathrm{gal} / 1,000 \mathrm{ft}^{2}$ of concrete processed of solids and liquids. The waste processing train involves multiple-unit operations for separation of the various contaminants.

9. Process applicability/flexibility: All shapes and forms except rubble.

10. Estimated cost: In the range of $\$ 7 / \mathrm{ft}^{2}$ depending on the level of contaminants and surface coating.

11. Stage of development: Prototype for radiological applications because of the stage of development of the waste processing unit. Commercial for non-radiological applications. 


\section{C-24}

12. Approximate number of full-scale projects: $>50$ for non-radiological applications.

13. Equipment availability: Immediate

14. Unusual potential environmental and/or safety risks: None; food-grade materials used for processing.

15. Other: Demonstration at $\mathrm{K}-25$ for radioactive, $\mathrm{Pb}$, and $\mathrm{PCB}$ contaminants. $\mathrm{K}-25$ felt process was slow and left residuals for further cleanup: 


\section{C-25}

\section{Accelerated Testing of Concrete Decontamination Methods Technology Description Fact Sheet}

1. Technology name: Soft Fiber Media Blasting (Advanced Recycle Media System)

2. Technology type: Physical/mechanical either destructive or non-destructive surface removal. Media treatment through physical separation and recycling.

3. Process description: Soft fiber media blasting is a surface to $1 / 8$-in.-deep removal cleaning process in which compressed air delivers a soft fiber, a sponge-like medium under pressure that impacts contaminated surfaces at high velocities. The soft fiber medium comes in two grades: the non-aggressive for surface cleaning only and the aggressive grade (impregnated with various abrasives such as garnet or steel shot) for removal of contaminated coatings and an up to $1 / 8$-in. layer of concrete. A light water vapor spray may be applied to the medium to keep down the dusting. The sponge itself will absorb vapors. The soft fiber medium can then be physically separated from the waste, reconstituted, and recycled.

4. Potential vendors, contact, and phone: GenCorp Aeroject, Brad Squibb, (615) $753-1388$

5. Level of cleanup: 90 to $99 \%$ of all contaminants; surface to $1 / 8$ in. of concrete

6. Processing rates: $100 \mathrm{ft}^{2} / \mathrm{h}$

7. Contaminants removed: Any.

8. Waste volume(s) and type: Basic dry solids, 1 to $2 \mathrm{ft}^{3} / 1000 \mathrm{ft}^{2}$ if medium is not recycled. If medium is separated and recycled, there is an additional 90 to $95 \%$ volume reduction.

9. Process applicability/flexibility: All shapes and forms except small rubble.

10. Estimated cost: $\$ 10$ to $12 / \mathrm{ft}^{2}$. Treatment available through licensed applicators.

11. Stage of development: Commercial

12. Approximate number of full-scale projects: 10 to 15 projects.

13. Equipment availability: Immediate 
14. Unusual potential environmental and/or safety risks: None identified.

15. Other: Used in projects with DOD for mixed waste and Scientific Ecology Group, Inc. for radioactive waste; none for DOE. 
APPENDIX D

REGULATORY ISSUES 


\section{APPENDIX D REGULATORY ISSUES}

The goals for decontaminating concrete are (1) to reduce or ideally eliminate radiological worker exposure, (2) minimize disposal cost by limiting the volume of waste that requires extensive management to comply with regulatory requirements, and (3) to reduce levels of contamination to below established limits such that it no longer requires handling as radioactive waste or such that the facility can be reused. This section provides information regarding pertinent regulatory and DOE requirements for the management of radiologically contaminated concrete and addresses radiological contamination only. Should the concrete contain other types of regulated waste materials (e.g., metals or PCBs), additional regulatory requirements may apply. Figure D.1 presents a logic flow diagram for the management of radiologically contaminated concrete. The sections that follow provide further details regarding the boxes presented in Fig. D.1.

\section{D.1 Determination of Disposition of Contaminated Concrete}

The need to consider concrete decontamination begins during the planning stages of $\mathrm{D} \& \mathrm{D}$ project involving a facility that is radiologically contaminated. To ensure that the handling and disposition of the concrete conforms to all regulatory requirements, radiological and chemical surveys are conducted, in conjunction with a review of historical records, to determine the waste category of the concrete (e.g., TRU waste, LLW, or hazardous waste). After the concrete has been appropriately characterized, a management plan can be prepared to identify the options for final disposition of the concrete. These options may include waste disposal, reuse of the intact building structure, or recycling of the concrete for other purposes. Depending on the level of contamination present, the concrete may need to be decontaminated to implement the selected option. The cost of the decontamination needs to be considered to ensure that the selected option is technically and economically feasible.

If concrete decontamination is not feasible, the primary final disposition option is to reduce the concrete to blocks and rubble for disposal as a radioactive waste. Decontamination technologies would be implemented when it is determined that the technology can (1) successfully remove or reduce the radiological hazards to allow free release of the concrete or (2) minimize the amount of concrete that would be managed as a radiological waste. Sections D.2 and D.3 describe the current regulatory requirements for free release and radiological waste disposal.

\section{D.2 Free Release}

The criteria described in this section are for the free release of property, equipment, and structures for reuse or recycling without the need for radiological controls. The current and proposed freerelease criteria being developed by $\mathrm{DOE}, \mathrm{NRC}$, and the EPA are discussed in the subsections that follow. 


\section{D.2.1 DOE Criteria}

The radiation criteria for protecting the public and the environment are contained in DOE Order 5400.5 (U.S. DOE 1990). This document establishes standards to ensure that potential exposure to radiation are maintained within excepted limits and to control radioactive contamination through the management of real and personal property. An additional objective is to maintain exposures below the limits by applying ALARA principles. Furthermore, DOE policy, as stated in this order, is to implement legally applicable radiation protection standards and to consider and adopt, as appropriate, recommendations by authoritative organizations [e.g., National Council on Radiation Protection and Measurements (NCRP) and International Commission on Radiological Protection (ICRP)]. This policy includes the intent to adopt and implement standards that are generally consistent with those of the NRC.

The release of real property (land and structures) shall be in accordance with the guidelines and requirements for residual radioactive material presented in DOE Order 5400.5, Chapter IV, and DOE Order 4300.1B. Prior to release, the responsible program organization, in conjunction with Environmental Health-1 (EH-1), is to certify that the property meets applicable release criteria for residual radioactivity and hazardous chemicals. Real properties that are sold to the public are also subject to the requirements of CERCLA Sect. 120(h) as they apply to hazardous substances and to other applicable federal, state, and local requirements. Materials and equipment, that could potentially be radioactively contaminated may be released for unrestricted use if the surface contamination limits presented in Table D.1 are met and the contamination has been subjected to ALARA evaluation. Where potentially contaminated surfaces are not accessible for measurement, materials and equipment may be released on a case-by-case basis if it can be demonstrated that, based on historical use, available measurements, and documentation, the unsurveyable surfaces are likely to be within the limits given in Table D.1. These case-by-case demonstrations could play an important role in the $D \& D$ of concrete where contamination may have penetrated into the concrete as a result of spilled liquids or where cracks are present in the concrete. DOE Order 5400.5 further states that there is no guidance currently available for the release of materials that are contaminated in depth, such as activated material or smelted contaminated metals. These volumetrically contaminated materials may be released if the criteria and survey techniques are approved by $\mathrm{EH}-1$.

Chapter IV of DOE Order 5400.5 presents the radiological protection requirements and guidelines for (1) cleanup of residual radioactive material and (2) management of the resulting waste and residues and release of property. Residual radioactive material is defined to be any radioactive material in soil, air, equipment, or structures as a consequence of past operations. The release of property is defined as the exercising of DOE authority to release property from its control after confirming that residual radioactive material on the property has been determined to meet the guidelines provided in Chapter IV and any other applicable radiological requirements, including ALARA. Each DOE element is to develop plans and protocols for implementing the Chapter IV guidelines. 
Chapter IV provides guidance on radiation protection of the public and environment from:

- residual concentrations of radionuclides in soil (including rubble and debris that might be present in the soil),

- concentrations of airborne radon-decay products,

- external gamma radiation,

- surface contamination, and

- radionuclide concentrations in air or water resulting from or associated with any of the above.

There are two types of guidelines for residual radioactive material, generic and specific. Material that is above the generic guidelines or alternate approved specific limits is to be managed according to DOE Order 5400.5. For materials classified as wastes, management is to be in accordance with DOE Order 5820.2A, which is further described in Sect. D.3.

\section{D.2.1.1 Generic Guidelines}

Generic guidelines, independent of the property, are taken from existing radiation protection standards. These guidelines for residual radioactive material, as they potentially apply to the free release of concrete, are as follows:

- Basic Dose Limit: The potential radiation exposure to residual radioactive material is not to exceed an effective dose equivalent, excluding background, of $100 \mathrm{mrem} / \mathrm{year}$. Additional information for applying the basic dose limit is described in the section for specific limits.

- Residual Radionuclides in Soil: Residual concentrations of radioactive material in soil are defined as those in excess of background concentrations averaged over an area of $100 \mathrm{~m}^{2}$. The Chapter IV definition of soil includes rubble and debris. If concrete is considered part of the soil, the generic guidelines for soil presented in Table D.1 could be used as the basis for releasing concrete.

- Airborne Radon-Decay Products: The radon-decay product concentration (including background) is not to exceed an annual average (or equivalent) of 0.02 working level (WL) or a maximum of $0.03 \mathrm{WL}$. This generic guideline applies to structures that are intended for free release without restriction. Structures that will be demolished or buried are excluded.

- External Gamma Radiation: In addition to complying with the basic dose limit for the "appropriate-use" scenario, the average level of gamma radiation shall not exceed background by more than $20 \mu \mathrm{R} / \mathrm{h}$. This generic guideline applies to structures that are intended for free release without restriction. Structures that will be demolished or buried are excluded. 
- Surface Contamination: The generic surface contamination guidelines are presented in Table D.1 [note that DOE Order 5400.5 does not provide generic guidelines for TRU elements; the values presented in parentheses are from NRC Regulatory Guide 1.86 (U.S. AEC 1974)]. These guidelines are applicable to existing structures, interior equipment, and building components that are potentially salvageable or recoverable scrap. For structures that are to be demolished, the guidelines for residual radionuclides in soil presented above apply to the resulting contamination in the ground.

- Residual Radionuclides in Air or Water: These generic guidelines would not normally be pertinent to the D\&D of concrete. However, they may need to be considered if residual concrete contamination could be a source of radionuclide migration to air or water.

\section{D.2.1.2 Specific Limits}

In lieu of applying a generic guideline, specific limits can be authorized on the basis of specific property data, including health, safety, practical, programmatic, and socioeconomic considerations. The specific limits are developed through project offices in the field and are approved by the Headquarters Program Office. The specific limits are to be derived from the basic dose limits (e.g., annual effective dose equivalent of $100 \mathrm{mrem}$ ) using "worst-case" or "plausibleuse" scenarios. Procedures and data for deriving specific property guideline values are contained in A Manual for Implementing Residual Radioactive Material Guidelines, DOE/CH8901 (U.S. DOE 1989). This manual contains pathway analysis methodology and guidance for applying the generic guidelines and also serves as a user's manual for using the RESRAD computer code in determining specific limits.

DOE/CH-8901 was recently updated as Manual for Implementing Residual Radioactive Material Guidelines Using RESRAD, Version 5.0 (ANL 1993). The version of the manual states that:

In order to comply with DOE Order 5400.5 requirements, potential doses from residual radioactive material must be well below the primary dose limit. Consistent with the recommendations of the International Commission on Radiological Protection (ICRP) regarding the establishment of dose constraints that are lower than the $100 \mathrm{mrem}$ in a year dose limit, DOE recommends that $30 \mathrm{mrem}$ in a year be generally applied as a constraint for dose to any individual under the actual use or likely future use scenarios. That is, remedial measures selected through the ALARA process must be sufficiently protective to ensure that likely potential doses will be less than 30 mrem from a year of exposure... the final authorized limits should be based on a realistic assessment of future use of the subject property, but they should be sufficiently protective to ensure that the other less likely but plausible use scenarios will not cause potential doses to exceed $100 \mathrm{mrem}$ in a year." 
Based on this guidance, the 30-mrem/year dose has been used to derive specific limits for current and likely future-use scenarios where the 100-mrem/year dose is used for less likely future-use scenarios. This guidance has been applied for establishing specific levels for radionuclides in soil at several DOE sites: the former Associate Aircraft Tool and Manufacturing Company Site, Fairfield, Ohio (Faillace et al. 1995); the former Baker Brothers, Inc., Site, Toledo, Ohio (Nimmagadda et al. 1995); 4400 Piehl Road Site, Ottawa Lake, Michigan (Faillace et al. 1994a); former Albacraft Laboratory Site, Oxford, Ohio (Nimmagadda et al. 1994); Brookhaven National Laboratory, Upton, New York (Faillace et al. 1994b). It is not known if this guidance has been applied to the free release of decontaminated concrete.

\section{D.2.1.3 Proposed 10 CFR 834}

$\mathrm{DOE}$ is in the process of promulgating public and environmental radiation protection standards contained in DOE Order 5400.5 as a regulation under 10 CFR 834. On March 25, 1993, DOE issued the proposed rule for review and comment. It is expected that the final rule will be published in March 1995 ( $\mathrm{H}$. Peterson, U.S. DOE, Office of Environmental Guidance, personal communication with D. Kennedy, Parsons Environmental Services, Dec. 12, 1994). A comparison between the order and the proposed rule with respect to residual radioactive materials follows:

- The proposed rule places a greater emphasis on using ALARA to demonstrate that doses to the public from the use of the property will be acceptable.

- The proposed rule maintains the 100-mrem/year dose limit, but clarifies that the dose limit includes all sources and pathways except for doses from background, radon and its decay products, medical sources, and consumer products. With respect to residual radioactive limits, DOE recognizes that the $100-\mathrm{mrem} /$ year limit applies to all radiation sources and pathways. As such, DOE expects that doses from its operations to be no more than a small fraction of the $100-\mathrm{mrem} / \mathrm{year}$ limit. However, this small fraction is not quantified with respect to free release of residual radioactive material.

- DOE has not included the generic surface contamination guidelines in the proposed rule (Table D.2). DOE, in conjunction with NRC and EPA, is investigating risk-based approaches to establishing surface contamination limits. DOE requested comment regarding the various approaches that may be applied.

- The proposed rule states that the property to be released is to be surveyed to determine mass contamination, removable surface radioactive material, and total surface radioactive material (including contamination present on and under any coatings). However, the rule does not identify how the surveys are to be performed, nor does it provide comparison criteria to determine if the survey results indicate that the material is acceptable for release. 


\section{D-6}

- Like DOE Order 5400.5, the proposed rule requires DOE approval of the documentation supporting the free release of the property. The documentation is to consist of (1) a description of the item, its radiological history, and the radiological condition of the property; (2) the DOE-approved criteria for release of the property; (3) the results of the survey, including date, surveyor's name, and identification of the instruments used; and (4) identification of the quantity and disposition of the waste resulting from any decontamination efforts and the recipient of the released property.

- The proposed rule states that DOE may authorize limits for the release of property containing residual radioactive material by considering (1) the nature of the property and its potential use; (2) whether or not the potential doses to an individual in the actual and likely-use scenarios are likely to exceed a small fraction of the applicable dose limits; (3) whether or not the potential dose to an individual in the worst plausible-use scenario is likely to exceed the applicable dose limits; (4) the collective dose to the affected population; and (5) where close contact is likely, the ability and need to decontaminate the property to ensure that there is no measurable contamination.

- The limits for soil and radon presented in the proposed rule are similar to those given in DOE Order 5400.5.

- The proposed rule allows DOE to establish supplemental limits in the event that the established limits do not provide adequate protection or are unnecessarily restrictive and costly. The supplemental limits could include appropriate engineering and/or administrative restrictions to prevent exposure to radioactive materials in excess of the 100 -mrem/year dose limit. DOE is responsible for coordinating the supplemental limits and associated restrictions as appropriate with the state and local governments.

\section{D.2.2 NRC Guidance and Proposed Rulemaking}

On June 27, 1988 (see 53 FR 24018), NRC published a final rule on general requirements for decommissioning nuclear facilities. However, this rule did not specifically address radiological criteria for decommissioned sites. NRC presently allows decommissioning of a site on a caseby-case basis in accordance with the following guidance documents: Termination of Operating Licenses for Nuclear Reactors, Regulatory Guide 1.86 (U.S. AEC 1974); Disposal or On-Site Storage of Thorium or Uranium from Past Operations (U.S. NRC 1981); and Termination of Byproduct, Source or Special Nuclear Materials Licenses,

Policy and Guidance Directive FC 83-23 (U.S. NRC 1983). The criteria for surface contamination limits presented in these NRC guides are similar to those presented in Table D.2. 
$\mathrm{NRC}$ is in the process of codifying radiological criteria for decommissioning in order to more effectively use NRC and licensee resources and to consistently apply these criteria to all types of sites for protecting public health and the environment. On August 22, 1994, NRC published a proposed rule (10 CFR 20, Subpart E) to establish radiological criteria for decommissioning (U.S. NRC 1994b). The provisions of the proposed rule are summarized below.

\section{Unrestricted Release:}

- The radiological limit for unrestricted use of a site is $15 \mathrm{mrem} / \mathrm{year}$ based on the total effective dose equivalent (TEDE) to an average member of the Critical Group for residual radioactivity distinguishable from background. TEDE estimates are to be based on the greatest annual dose expected within the first 1,000 years after decommissioning. NRC is to publish guidance for estimating the annual TEDE, including exposure scenarios, pathways, factors, and computer models. Although ICRP and NCRP recommend that a $100-\mathrm{mrem} / \mathrm{year}$ dose limit is protective of public health, NRC chose the 15-mrem/year limit to provide an additional safety margin since the 100-mrem/year limit is intended to apply to public doses resulting from all radiation sources. As such, NRC believed that the allocation of the entire 100-mrem/year limit to residual radioactivity from the decommissioning of a single facility is not appropriate. Using a 30-year exposure lifetime, the estimated individual excess lifetime cancer risk associated with an annual TEDE of $15 \mathrm{mrem} / \mathrm{year}$ would be approximately $2 \times 10^{-4}$.

- The NRC licensee must conduct an ALARA evaluation in deciding what levels should be achieved below the 15-mrem/year limit. The ALARA process is to consider all significant radiation doses and risks resulting from the residual radioactivity and the decommissioning process itself, including transportation and disposal of radioactive waste. The ALARA evaluation is also to consider inadvertent recycle. NRC consi- ders that the ALARA requirement has been met if the TEDE contribution to residual radioactivity is less than $3 \mathrm{mrem} / \mathrm{year}$. NUREG 1500, Regulatory Guide on Release Criteria for Decommissioning, is to provide guidance regarding the application of ALARA to D\&D projects, including how a licensee can demonstrate compliance with ALARA without having to perform sophisticated analyses or modeling.

- The licensee is also required to remove all readily removable residual radioactivity from a site before it is decommissioned. Readily removable is defined to be removable using non-destructive, common, housekeeping techniques (e.g., washing with moderate amounts of detergent and water) that do not generate large volumes of radioactive waste requiring subsequent disposal. Techniques that produce chemical wastes that are expected to adversely affect public health or the environment, or the removal and transport of soil, except in small, discrete areas, would not be included. 


\section{D-8}

\section{$\underline{\text { Restricted Release }}$}

- The licensee must demonstrate that further reduction in the residual radioactivity levels to comply with the 15 -mrem/year standard is not technically feasible, is prohibitively expensive, or would result in net public or environmental harm.

- It is necessary to achieve the $15-\mathrm{mrem} / \mathrm{year}$ limit with restrictions in place. The radiation dose without restrictions is not to exceed $100 \mathrm{mrem} / \mathrm{year}$. Calculations used to show compliance with the 100-mrem/year standard cannot include any benefits from earthen cover or other earthen barriers unless specifically authorized by the NRC.

- A site-specific advisory board (SSAB) consisting of local and state officials, community organizations, site representatives, and others is to be formed to advise the licensee regarding the appropriate clean-up levels and controls to protect human health. The SSAB recommendations are to be considered during the planning stages (i.e., development of the decommissioning plan).

- Environmental review in accordance with the National Environmental Policy Act (NEPA) will be required.

- The licensee must provide financial assurance for maintaining the restrictive controls.

\section{Other Considerations}

- NRC plans to propose additional regulations to address controls for the intentional reuse/recycle of radioactively contaminated material. In the interim, NRC will continue to review these actions on a case-by-case basis. It is not clear what criteria $\mathrm{NRC}$ intends to use to determine whether material can be free released [e.g., the 15 -mrem/year dose standard or the surface radioactivity contamination levels provided in Regulatory Guide 1.86 (U.S. AEC 1974)].

- The licensee is to evaluate the risks, costs, and benefits to determine if previously buried wastes are required to be exhumed and removed from the site.

- NUREG/CR-5849, Manual for Conducting Radiological Surveys in Support of License Termination, is intended to provide licensees with specific guidance on demonstrating that site decontamination achieves the NRC-specified levels.

NUREG/CR-5512 is to provide an acceptable method for determining the TEDE (U.S. NRC 1992). NRC is also to publish guidance on acceptable methods that can be used by the licensee to demonstrate that the concentrations of specific isotopes are indistinguishable from background. 
- To the extent practical, actual measurements are to be used to verify TEDEcalculated doses.

- NRC states that the human health radiological criterion (i.e., $15 \mathrm{mrem} / \mathrm{year}$ ) is protective of the environment. As such, the NRC is not establishing separate criteria for the protection for the environment.

\section{D.2.3 EPA Radiation Protection Standards}

Under the Atomic Energy Act and Reorganization Plan No. 3 of 1970, EPA has the statutory responsibility to establish generally applicable standards for protecting public health and the environment from radioactive material (i.e., outside NRC licensee and DOE site boundaries). NRC and DOE are responsible for ensuring that site activities do not lead to radiation doses outside the facility boundaries that exceed EPA's generally applicable standards. EPA is in the process of developing two regulations that will apply to D\&D of radioactive sites. The first regulation, Radiation Site Cleamup Regulation, was to be promulgated as 40 CFR 196 (U.S. EPA 1993a). EPA published an Advance Notice of Proposed Rulemaking on October 21, 1993, announcing EPA intent to prepare clean-up regulations and soliciting comments, information, and data that apply to the rulemaking effort (U.S. EPA 1993a). EPA also published an Issues Paper on Radiation Site Cleanup Regulations to facilitate and focus discussion by examining regulatory issues and approaches for developing the radiation site cleanup regulations (U.S.EPA 1993b). After 40 CFR 196 is finalized, EPA plans to promulgate regulations to address the treatment, storage, and disposal of radioactive waste generated During site remediation. Under the waste management rulemaking, EPA will explore the feasibility of recycling or reusing site structures, equipment, and metals after cleanup.

Although the EPA rules would not apply directly to D\&D activities conducted within the boundaries under the control of DOE or an NRC licensee, the EPA rule could be applicable in instances where the site and/or materials are intended to be released to the public for unrestricted use. NRC and DOE have been working with EPA in developing standards for residual radioactivity. A Memorandum of Understanding signed between EPA and NRC discusses how the two agencies will avoid overlapping regulations affecting NRC license holders (57 FR 54127). EPA may exclude NRC-licensed facilities from coverage under its rulemaking based upon a determination as to whether the NRC regulatory program achieves a sufficient level of protection of public health and the environment.

Currently, EPA is leaning toward setting a risk level, for the reasonably maximally exposed individual, of about $10^{-4}$ over the risk posed by background radiation. EPA has preliminarily determined that a $10^{-4}$ risk level is consistent with other environmental protection programs and that that clean-up level is measurable and verifiable. For example, EPA radiation protection regulations and guidance specify standards corresponding to risk limits ranging from $10^{-3}$ to $10^{-4}$, except for radon, which is $10^{-2}$. Other environmental protection programs, including Superfund, also accept a $10^{-4}$ risk as protective of human health. The EPA High-Level Waste 
Rule sets a dose limit corresponding to an estimated lifetime excess cancer risk of $5 \times 10^{-4}$ (40 CFR 190). International, nongovernmental agencies, such as the ICRP, also recommend limiting exposures to levels that roughly correspond to a $10^{-4}$ risk.

\section{D.2.4 ANSI N13.12}

The American National Standards Institute (ANSI) draft N13.12 Surface Radioactivity Guides for Materials, Equipment, and Facilities to be Released for Uncontrolled Use has been in development since 1968 (Ring 1994). The standard has gone through many revisions, including complete rewrites. It was approved as a Health Physics Society Standard in 1987, though it has not yet been approved by ANSI. The standard is currently being redrafted based on dose and its subsequent risk, rather than simply risk. It is planned that the formal review process will begin in 1995. Table D.3 shows the standard currently presented [for comparison purposes to the Regulatory Guide 1.86 table (U.S. AEC 1974) currently used by DOE and NRC].

\section{D.3 Waste Disposal}

The current conservative definition of a radioactive waste is any solid, liquid, or gaseous material containing radionuclides, distinguishable from background levels, that is to be discarded. On July 3, 1990, NRC published its Below Regulatory Concern (BRC) Policy (55 FR363279). The BRC policy established a risk criteria that NRC proposed for formulating rules to exempt small quantities of radioactive materials from certain regulatory requirements. The policy included: (1) the release of lands and structures containing residual radioactivity for unrestricted public use, (2) the distribution of consumer products containing small amounts of radioactive materials, (3) the disposal of very low-level radioactive waste at other then-licensed disposal sites, and (4) the recycling of slightly contaminated equipment and materials. The BRC policy generated widespread public concern and controversy, whereupon the NRC withdrew the policy on July 30, 1991 (56 FR 398012). NRC's proposed decommissioning rule currently addresses only item (1) listed above (proposed 10 CFR 20, Subpart E); criteria for recycling material and disposing of very low-level radioactive waste at a non-radioactive disposal facility have not been proposed. DOE has also been evaluating criteria for establishing BRC and de minimis limits.

Since formal criteria have not been established for BRC radioactivity limits, it is unclear if slightly contaminated concrete can be released for recycle or disposal at a local solid waste landfill. For the purpose of this report, it is assumed that in order for concrete to be disposed of in a non-radioactive landfill (i.e., not on a DOE site or site licensed by the NRC), the radioactivity levels will need to be indistinguishable from background levels. However, it may be possible to obtain state and local regulatory approval for the disposal of slightly contaminated concrete at a non-radioactive landfill on a case-by-case basis. Súch management practices must be approved by DOE. The lack of BRC limits would not be a regulatory barrier for 
recycling concrete since the concrete would not be a waste material. However, given the pending changes in the radiological criteria, recycling criteria must be established on a caseby-case with the concurrence of EH-1. For the purpose of this report, it is assumed that concrete that meets the decommissioning criterion is suitable for recycle.

If the concrete is to be managed as a radioactive waste, the disposal requirements will vary with respect to the level and type on radiological contamination. Although this report does not specifically address the management of non-radioactive waste components, regulations such as RCRA and the TSCA may dictate additional treatment and disposal requirements. Regulations and management procedures have been established for five different categories of radioactive waste to ensure the proper handling of radioactive waste. The disposal of radiologically contaminated concrete and/or decontamination treatment residues will need to follow the requirements of DOE Order 5820.2A (U.S. DOE 1988). The radioactive waste categories and associated definitions are as follows:

HLW: As defined in the Nuclear Waste Policy Act, this radioactive waste is either (1) the highly radioactive material resulting from the processing of spent nuclear fuel, including liquid waste produced directly in reprocessing and any solid material derived from such liquid waste that contains fission products in sufficient concentrations; or (2) other highly radioactive material that NRC, consistent with existing law, determines by rule requires permanent isolation. It is assumed that radiologically contaminated concrete will never be classified as HLW. As such, requirements for the management of HLW are not presented.

Spent Nuclear Fuel (SNF): As defined in the Nuclear Waste Policy Act, this radioactive waste is the spent nuclear fuel withdrawn from a nuclear reactor following irradiation, the constituent elements of which have not been separated by processing. It is assumed that radiologically contaminated concrete will never be classified as SNF. As such, requirements for the management of SNF are not presented.

TRU Waste: As defined in 40 CFR 191, this is any waste contaminated with alpha-emitting transuranic radionuclides (e.g., atomic number greater than 92) that have a half-life greater than 20 years and are in concentrations greater than $100 \mathrm{nCi} / \mathrm{g}$. It is envisioned that some highly contaminated concrete (e.g., from hot cells) may need to be managed as TRU waste. All TRU waste is to be disposed at WIPP. TRU waste must be packaged to meet the waste acceptance criteria established for WIPP.

By-Product Material: As defined in the Atomic Energy Act, this waste is the tailings or wastes produced by the extraction or concentration of uranium or thorium from any ore processed primarily for its source material content. It is assumed that radiologically contaminated concrete will never be classified as by-product material. As such, requirements for the management of by-product material are not presented. 


\section{D-12}

LLW: As defined in the Low-Level Radioactive Waste Policy Act, this waste is radioactive waste not classified as HLW, SNF, TRU waste, or by-product material as defined in Section 11(e)(2) of the Atomic Energy Act of 1954. It is anticipated that most contaminated concrete will need to be managed as LLW. This type of waste can either be disposed of at a DOE disposal facility (i.e., NTS, Hanford, or INEL) or at an appropriately permitted/licensed nonDOE facility. The use of non-DOE facilities requires prior DOE approval: it is DOE policy that DOE LLW be disposed of on the site at which it is generated, if practical, or if on-site disposal capacity is not available, at another DOE disposal facility (see DOE Order 5820.2A, Chapter III.2.a) (U.S.DOE 1988). Currently, DOE has approved the use of the commercial EnviroCare waste facility in Utah for the disposal of certain waste. Since each disposal facility has different waste acceptance criteria, decommissioning efforts will need to be planned so that waste can be taken to the selected facility.

Should a NRC-licensed disposal facility be used, the criteria contained in 10 CFR 61 should be evaluated to ensure that the appropriate disposal requirements are met. The disposal requirements for LLW are subdivided into three classes depending on the nature of the waste and the radionuclide concentrations:

- Class A waste consists primarily of short-lived radionuclides and can be disposed with minimal requirements.

- Class B waste contains a greater concentration of radionuclides and needs to be in a stable form prior to disposal.

- Class $\mathrm{C}$ waste remains radioactive for longer periods of time and requires more stringent waste disposal requirements (note: Greater than Class $\mathrm{C}$ waste is not accepted for shallow land disposal as LLW unless special permission is received from NRC; DOE is responsible for the disposal of Greater than Class C waste). 


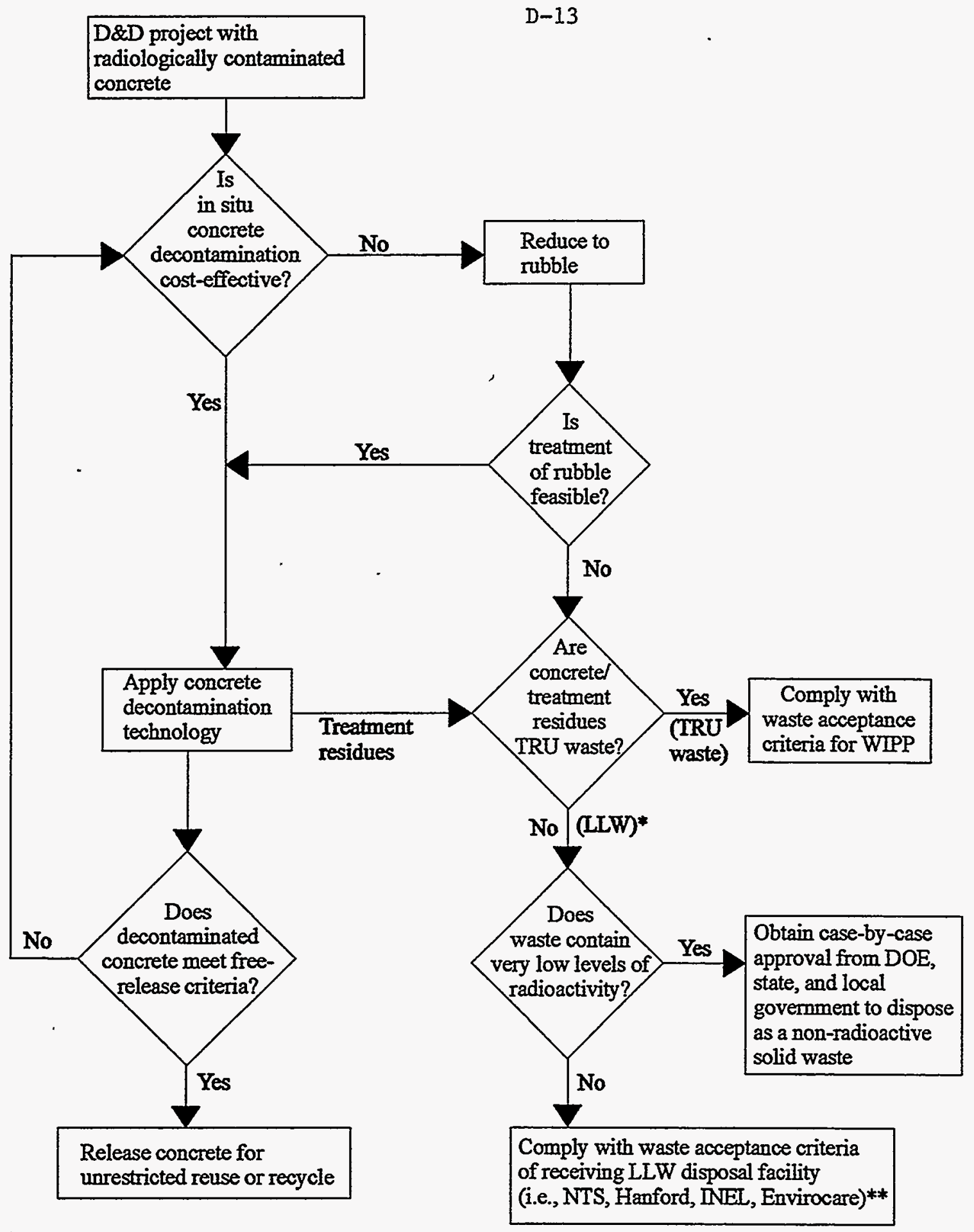

* It is assumed that the concrete and treatment residues will either be classified as TRU waste or LLW.

** Other restricted uses for radiologically contaminated concrete may be possible, such as LLW disposal vaults and/or containers or a solidification agent for other radioactive waste.

Fig. D.1. Regulatory logic flow diagram. 
Table D.1. Generic guidelines for residual radionuclides in soil

\begin{tabular}{|c|c|c|}
\hline Radionuclide & Criteria & Comments \\
\hline${ }^{226} \mathrm{Ra},{ }^{228} \mathrm{Ra},{ }^{230} \mathrm{Th}$, and ${ }^{232} \mathrm{Th}$ & $\begin{array}{l}5 \mathrm{pCi} / \mathrm{g} \text { (averaged over the first } 15 \mathrm{~cm} \text { of soil } \\
\text { below the surface). } \\
15 \mathrm{pCi} / \mathrm{g} \text { (averaged over } 15-\mathrm{cm} \text {-thick layers of } \\
\text { soil more than } 15 \mathrm{~cm} \text { below the surface). }\end{array}$ & $\begin{array}{l}\text { The residual concentrations provided } \\
\text { assumes secular equilibrium. If the } \\
\text { radionuclides are not in secular } \\
\text { equilibrium, the appropriate guideline is } \\
\text { applied as a limit for the radionuclide } \\
\text { with the higher concentration. }\end{array}$ \\
\hline Other radionuclides & $\begin{array}{l}\text { Residual concentrations shall be derived from } \\
\text { the basic dose limits by means of an } \\
\text { environmental pathway analysis using specific } \\
\text { property data where available. }\end{array}$ & \\
\hline $\begin{array}{l}\text { Hot spots (for areas equal to } \\
\text { or less than } 25 \mathrm{~m}^{2} \text { ) }\end{array}$ & $\begin{array}{l}\text { Residual concentration shall not exceed the } \\
\text { radionuclide soil limit times }(100 / \mathrm{A})^{0.5} \text {, where } \\
\mathrm{A} \text { is the area in square meters. Reasonable } \\
\text { efforts shall be made to remove any source of } \\
\text { radionuclides that exceed } 30 \text { times the limit, } \\
\text { regardless of the average concentration in } \\
\text { soil. }\end{array}$ & $\begin{array}{l}\text { If average concentration exceeds the } \\
\text { radionuclide soil limit times }(100 / \mathrm{A})^{0.5} \\
\text { DOE/CH- } 8901 \text { shall be used to calculate } \\
\text { hot-spot limits. }\end{array}$ \\
\hline Mixtures of Radionuclides & $\begin{array}{l}\text { Residual radioactivity is not to exceed the } \\
\text { basic dose limit or the sum of the ratios of the } \\
\text { soil concentration of each radionuclide to the } \\
\text { allowable limit for that radionuclide will not } \\
\text { exceed } 1 \text {. }\end{array}$ & $\begin{array}{l}\text { Explicit formulas for calculating residual } \\
\text { concentration guidelines for mixtures are } \\
\text { given in DOE/CH-8901. }\end{array}$ \\
\hline
\end{tabular}


Table D.2. Surface contamination limits

\begin{tabular}{|c|c|c|c|}
\hline \multicolumn{4}{|c|}{$\begin{array}{c}\text { Figure IV-1 } \\
\text { Surface Contamination Guidelines }\end{array}$} \\
\hline \multirow{2}{*}{ Radionuclides $^{b}$} & \multicolumn{3}{|c|}{$\begin{array}{l}\text { Allowable Total Residual Surface Contamination } \\
\qquad\left(\mathrm{dpm} / 100 \mathrm{~cm}^{2}\right)^{a}\end{array}$} \\
\hline & Average $^{c, d}$ & Maximum $^{d_{, e}}$ & Removable $e^{d f}$ \\
\hline $\begin{array}{l}\text { Transuranics, I-125, I-129, } \\
\text { Ra-226, Ac-227, Ra-228, } \\
\text { Th-228, Th-230, Pa-231. }\end{array}$ & $\begin{array}{l}\text { RESERVED } \\
(100)\end{array}$ & $\begin{array}{l}\text { RESERVED } \\
(300)\end{array}$ & $\begin{array}{l}\text { RESERVED } \\
(20)\end{array}$ \\
\hline $\begin{array}{l}\text { Th-Natural, Sr-90, I-126, } \\
\text { I-131, I-133, Ra-223, } \\
\text { Ra-224, U-232, Th-232. }\end{array}$ & 1,000 & 3,000 & 200 \\
\hline $\begin{array}{l}\text { U-Natural, U-235, U-238, } \\
\text { and associated decay } \\
\text { product, alpha emitters. }\end{array}$ & 5,000 & 15,000 & 1,000 \\
\hline $\begin{array}{l}\text { Beta-gamma emitters } \\
\text { (radionuclides with decay } \\
\text { modes other than alpha } \\
\text { emission or spontaneous } \\
\text { fission) except } \mathrm{Sr}-90 \text { and } \\
\text { others noted above. }\end{array}$ & 5,000 & 15,000 & 1,000 \\
\hline
\end{tabular}

a As used in this table, dpm (disintegrations per minute) means the rate of emission by radioactive material as determined by correcting the counts per minute measured by an appropriate detector for background, efficiency, and geometric factors associated with the instrumentation.

b Where surface contamination by both alpha- and beta-gamma-emitting radionuclides exists, the limits established for alpha- and beta-gamma-emitting radionuclides should apply independently.

- Measurements of average contamination should not be averaged over an area of more than $1 \mathrm{~m}^{2}$. For objects of less surface area, the average should be derived for each such object.

${ }^{d}$ The average and maximum dose rates associated with surface contamination resulting from beta-gamma emitters should not exceed $0.2 \mathrm{mrad} / \mathrm{h}$ and $1.0 \mathrm{mrad} / \mathrm{h}$, respectively, at $1 \mathrm{~cm}$.

- The maximum contamination level applies to an area of not more than $100 \mathrm{~cm}^{2}$.

$f$ The amount of removable material per $100 \mathrm{~cm}^{2}$ of surface area should be determined by wiping an area of that size with dry filter or soft absorbent paper, applying moderate pressure, and measuring the amount of radioactive material on the wiping with an appropriate instrument of known efficiency. When removable contamination on objects of surface area less than $100 \mathrm{~cm}^{2}$ is determined, the activity per unit area should be based on the actual area and the entire surface should be wiped. It is not necessary to use wiping techniques to measure removable contamination levels if direct scan surveys indicate that the total residual surface contamination levels are within the limits for removable contamination.

8 This category of radionuclides includes mixed fission products, including the $\mathrm{S} r-90$ which is present in them. It does not apply to Sr- 90 which has been separated from the other fission products or mixtures where the Sr-90 has been enriched.

Source: U.S. DOE. 1990. 


\section{D-16}

Table D.3. ANSI Surface Radioactivity Guides

\begin{tabular}{|c|c|c|c|}
\hline \multicolumn{4}{|c|}{$\begin{array}{l}\text { Surface Radioactivity Guides } \\
1978 \text { Draft to Date }\end{array}$} \\
\hline \multirow[b]{2}{*}{ Group } & \multirow[b]{2}{*}{ Description } & \multicolumn{2}{|c|}{ Activity Guide per $100 \mathrm{~cm}^{2}$} \\
\hline & & Removable & $\begin{array}{c}\text { Total } \\
\text { (Fixed }+ \text { Removable) }\end{array}$ \\
\hline 1 & $\begin{array}{l}\text { All alpha emitters except those with extremely } \\
\text { low specific activity and their associated decay } \\
\text { products as listed in Group } 4 ;{ }^{210} \mathrm{~Pb},{ }^{228} \mathrm{Ra} \text {. }\end{array}$ & 20 & 300 \\
\hline 2 & 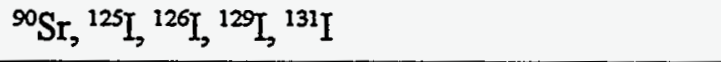 & 200 & 5000 \\
\hline 3 & $\begin{array}{l}\text { All beta and gamma emitters not specified in } \\
\text { Groups } 1,2 \text {, and } 4 \text { except pure beta emitters } \\
\text { with } E_{\max } \geq 150 \mathrm{keV} \text {. }\end{array}$ & 1000 & 5000 \\
\hline 4 & Uranium (natural, depleted, enriched), $T_{h}$ nat & 200 & 1000 \\
\hline
\end{tabular}

